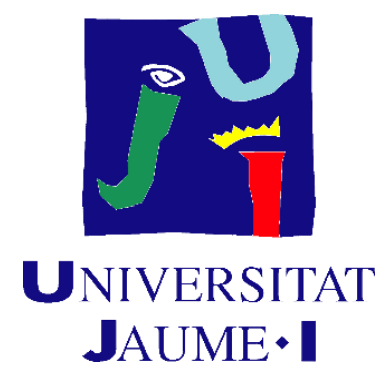

Programa de Doctorado en Ciencias

Escuela de Doctorado de la Universitat Jaume I

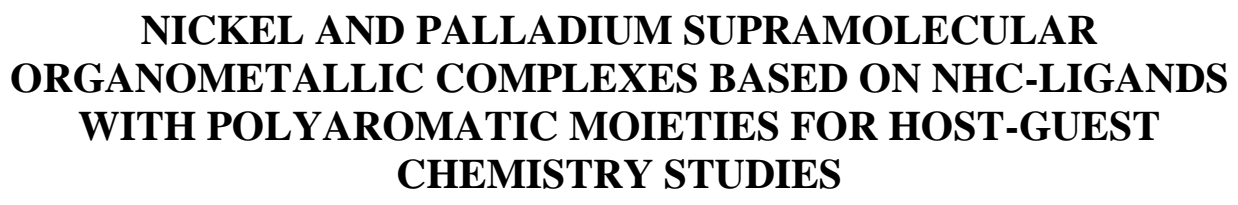

Memoria presentada por Víctor Martínez Agramunt para optar al grado de doctor/a por la Universitat Jaume I

Víctor Martínez Agramunt

$\begin{array}{ll}\text { VICTOR| } & \begin{array}{l}\text { Firmado digitalmente } \\ \text { por VICTOR|MARTINEZ| }\end{array} \\ \text { MARTINEZ| } & \text { AGRAMUNT } \\ \text { Fecha: } 2020.07 .29 \\ \text { AGRAMUNT } & 13: 21: 42+02^{\prime} 00^{\prime}\end{array}$

Eduardo Peris Fajarnés

$\begin{array}{ll}\text { EDUARDO } & \begin{array}{l}\text { Firmado } \\ \text { digitalmente por } \\ \text { EDUARDO VICTOR }\end{array} \\ \text { VICTOR| } & \text { PERIS|FAJARNES } \\ \text { PERIS| } & \text { Fecha: } 2020.07 .29 \\ \text { FAJARNES } & 13: 38: 21+02^{\prime} 00^{\prime}\end{array}$

Castellón de la Plana, Julio de 2020 



\section{Financiación recibida}

Agencias financiadoras del doctorando

- $\quad$ Universitat Jaume I (PREDOC/2016/59)

- $\quad$ Generalitat Valenciana (ACIF/2017/189)

Agencias financiadoras del proyecto de investigación o de los recursos materiales específicos del grupo de investigación.

- $\quad$ Ministerio de economia i competitividad (CTQ2014-51999-P)

- $\quad$ Universitat Jaume I (P11B2014-02)

- $\quad$ Universitat Jaume I (UJI-B2017-07)

- $\quad$ Ministerio de Ciencia y Universidades (PGC2018-093382-B-I00) 

Related articles

Tesis por compendio de las siguientes publicaciones:

I) V. Martínez-Agramunt, S. Ruiz-Botella, E. Peris. Nickel-Cornered Molecular Rectangles as Polycyclic Aromatic Hydrocarbon Receptors. Chemistry A European Journal $23 \quad$ (2017) 6675-6681. http://onlinelibrary.wiley.com/doi/10.1002/chem.201700703/epdf. Factor de impacto: 5.160

II) V. Martínez-Agramunt, D. Gussev, E. Peris. A Shape-Adaptable Organometallic Supramolecular Coordination Cage for the Encapsulation of Fullerenes. Chemistry A European Journal 24 (2018) 14802-14807. https://onlinelibrary.wiley.com/doi/full/10.1002/chem.201803034. Factor de impacto: 5.160

III) V. Martínez-Agramunt, T. Eder, H. Darmandeh, G. Guisado-Barrios, E. Peris. A Size-Flexible Organometallic Box for the Encapsulation of Fullerenes. Angewandte Chemie International Edition 58 (2019) 5682-5686. https://onlinelibrary.wiley.com/doi/10.1002/anie.201901586. Factor de impacto: 12.257

IV) V. Martínez-Agramunt, E. Peris. Photocatalytic Properties of a Palladium Metallosquare with Encapsulated Fullerenes via Singlet Oxygen Generation. Inorganic Chemistry 58 (2019) 11836-11842. https://pubs.acs.org/doi/10.1021/acs.inorgchem.9b02097. Factor de impacto: 4.850 


\section{Related articles}

V) V. Martínez-Agramunt, E. Peris. A palladium-hinged organometallic square with a perfect-sized cavity for the encapsulation of three heteroguests.

Chemical Communications $55 \quad$ (2019) 14972-14975. https://pubs.rsc.org/en/Content/ArticleLanding/CC/2019/C9CC08595E\#!div Abstract. Factor de impacto: 6.164 
Related articles

"Esta tesis dispone de la aceptación de los coautores de las publicaciones que el doctorando presenta como tesis y su renuncia expresa a presentarlas" 



\section{LIST OF ABBREVIATIONS}

$\begin{array}{ll}\Delta & \text { Refluxing temperature } \\ \eta & \text { Ligand hapticity } \\ n \text { Bu } & \text { Wavelength } \\ \text { DCB } & \text { normal-butyl } \\ \text { DFT } & \text { Dichlorobenzene } \\ \text { DMF } & \text { Dimethylformamide } \\ \text { DOSY } & \text { Diffusion-ordered spectroscopy } \\ \text { Eq } & \text { Equivalent } \\ \text { ESI-MS } & \text { Electrospray Ionization Mass Spectrometry } \\ \text { HRMS } & \text { High Resolution Mass Spectrometry } \\ \text { M-C } & \text { Metal-carbon } \\ \text { Me } & \text { Methyl } \\ \text { MeCN } & \text { Acetonitrile } \\ \text { min } & \text { Minute } \\ \text { M-M } & \text { Metal-Metal distance } \\ \text { MS } & \text { Mass Spectrometry } \\ \text { NHC } & \text { Mass to charge ratio } \\ \text { N-heterocyclic carbene } \\ \text { M }\end{array}$


NMR Nuclear Magnetic Resonance

$\delta \quad$ Chemical shift

d Doublet

J Coupling constant

m Multiplet

ppm Parts per million

s Singlet

t Triplet

NTCDI Napthalene Tetracarboxidiimide

NOESY Nuclear Overhauser Effect Spectroscopy

RT Room temperature

PAH Polycylic Aromatic Hydrocarbon

PDT Photodynamic Therapy Treatment

SCC Supramolecular Coordination Complex

SOC Supramolecular Organometallic Complex

$t \mathrm{Bu} \quad$ tertiary-butyl

THF Tetrahydrofuran

US Ultrasound

UV-Vis Ultraviolet-Visible 
Index

\section{INDEX}

1. Introduction Page - 13-

1.1 Supramolecular Chemistry Page - 14 -

1.1.1 Self-Assembly Page - 15 -

1.2 Metallosupramolecular Chemistry Page - 16 -

1.2.1 Coordination-driven self-assembly Page - 17-

1.2.2 Supramolecular Coordination Complexes Page - 17-

1.2.2.1 Werner-type linker based SCC Page - 18 -

1.2.3 Host-Guest Chemistry Page - 24 -

1.2.3.1 Receptors for Polycyclic Aromatic Hydrocarbons Page - 25 -

1.2.3.2 Metallocages as fullerene hosts Page - 30 -

1.3 Supramolecular Organometallic Compounds Page - 33-

1.3.1 Background Page - 33-

1.3.2 SOCs developed in the QOMCAT Group Page - 39 -

1.4 References $\quad$ Page - 41-

2. Objectives Page - 57 -

2. Objetivos Page - 59-

3. Summary Page - 61-

3. Resumen Page - 71- 
Index

4. Article 1: Nickel-Cornered Molecular Rectangles as Polycyclic Aromatic Hydrocarbon Receptors.

Page - 81 -

5. Article 2: A Shape-Adaptable Organometallic Supramolecular Coordination Cage for the Encapsulation of Fullerenes. Page -111-

6. Article 3: A Size-Flexible Organometallic Box for the Encapsulation of Fullerenes Page -133-

7. Article 4: Photocatalytic Properties of a Palladium Metallosquare with Encapsulated Fullerenes via Singlet Oxygen Generation. Page -149-

8. Article 5: A-palladium-hinged organometallic square with a perfectsized cavity for the encapsulation of three heteroguests. Page -175-

9. Conclusions

Page -193-

9. Conclusiones

Page -195- 
1. Introduction

\section{INTRODUCTION}

\section{Supramolecular Chemistry}

1.1 Self-Assembly

\section{Metallosupramolecular Chemistry}

2.1 Coordination-driven self-assembly

2.2 Supramolecular Coordination Complexes (SCC)

2.2.1 Werner-type linker based SCC

2.3 Host-Guest Chemistry

2.3.1 Receptors for Polycyclic Aromatic Hydrocarbons

2.3.2 Metallocages as fullerene hosts

\section{Supramolecular Organometallic Compounds (SOCs)}

3.1 Background

3.2 SOCs developed in the QOMCAT Group 


\section{Supramolecular Chemistry}

Supramolecular chemistry is the field of research that deals with the chemistry and collective behavior of organized ensembles of molecules. Supramolecular chemistry has grown during the last decades into a mature field of modern science whose interfaces with several disciplines have provided invaluable opportunities for crossing boundaries, both inside and between the fields of chemistry, physics and biology. ${ }^{[1-5]}$

Supramolecular chemistry has progressively developed with the synthesis of numerous unique architectures each year. Based on the interactions involved in the assembling, it has been proposed that supramolecular chemistry can be broadly classified into three main branches, as it is depicted in Scheme 1. ${ }^{[6]}$ These branches are: (i) those that utilize H-bonding motifs in the supramolecular architectures; (ii) those that utilize other noncovalent interactions, such as ion-ion, ion-dipole, $\pi-\pi$ stacking, cation- $\pi$, van der Waals, and hydrophobic interactions; and (iii) those that employ strong, and directional metal-ligand bonds for the assembly process. Nevertheless, the assembly of small molecular units into large, discrete supramolecules becomes more sophisticated as the scale and degree of complexity of the desired molecules increase. This has been mainly due to the lack of control in the directionality of the weak forces employed in the first two classifications above.

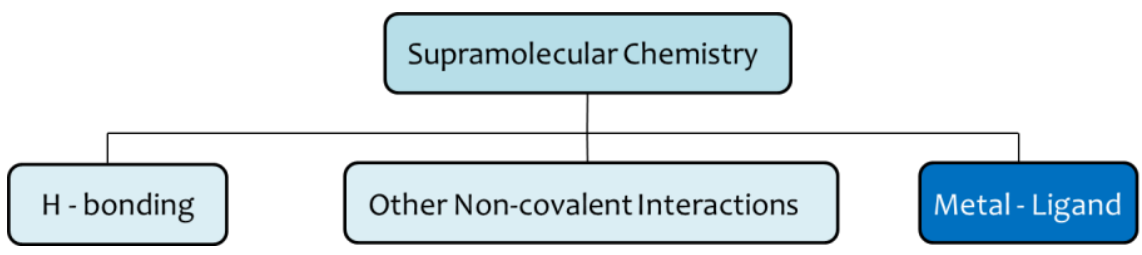

Scheme 1: Classification of Supramolecular chemistry according the type of non-covalent interactions. 


\subsection{Self-Assembly}

After the discovery of "crown ethers"; "cryptands", and "spherands" more than fifty years ago respectively by Pedersen, ${ }^{[7]}$ Lehn $^{[1]}$ and Cram, ${ }^{[8]}$ it was realized that complementary molecules can aggregate through noncovalent interactions. As depicted in Scheme 1, these interactions mainly include hydrogen bonding, donor-acceptor attraction, $\pi-\pi$ stacking interaction and van der Waals forces. ${ }^{[9-14]}$ This molecular complementarity can thus be used for the self-assembly of different blocks by utilizing these interactions to form large supramolecules, which may end up by having significant different physicochemical properties compared to those of the precursor individual building blocks. Self-assembly is a phenomenon where the components of a system assemble themselves without external direction to form a larger functional unit. The self-assembly process is produced in a way that the thermodynamically most stable architecture is produced via numerous associative and dissociative reversible steps (Scheme 2).
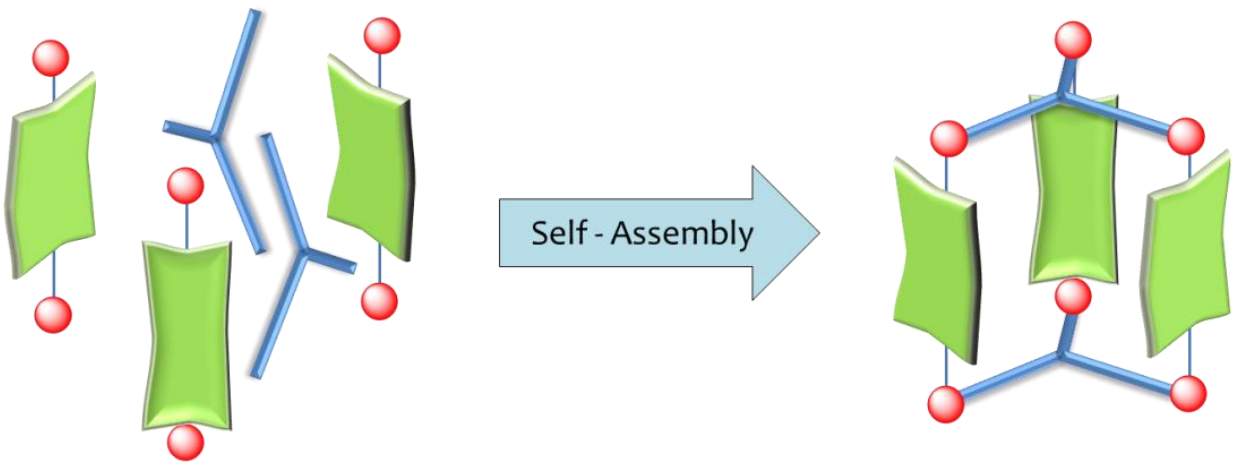

Scheme 2: Schematic representation of a typical self-assembly process

The process is typically kinetically reversible. Nevertheless, the reaction equilibrium can be shifted towards the desired product by modulating 
various reaction parameters. It is due to this fact that self-assembly has an exclusive advantage over traditional, stepwise synthetic approaches when accessing large molecules. The simplicity of self-assembly has resulted in a plethora of self-assembled capsules and cages with nanometer-sized cavities. ${ }^{[15-18]}$ Self-assembly is also present in nature. In fact, it is the fundamental technique employed by nature to construct the elegant and intricate molecular machinery from which life is built. ${ }^{[19]}$ The directional bonding approach ${ }^{[19]}$ allows the outcome of the self-assembly process to be guided by the information provided by the building units (coordination angles, number of coordination sites, shape and length of the connecting ligands), so that the outcome of the self-assembly process can be predicted with a reasonably high level of accuracy.

\section{Metallosupramolecular chemistry}

Metallo-supramolecular chemistry can be defined as the chemistry involving the combination of bridging organic ligands with metal units that form discrete or polymeric assemblies of different shapes and sizes. ${ }^{[6,19-25]}$ The grounds of this discipline is the availability of rigid ligands with two or more binding sites, which in combination with suitable metal fragments, form highly symmetrical structures with a variety of shapes and sizes. ${ }^{[19,21-22,}$ ${ }^{24]}$ It is precisely the rich coordination chemistry of transition metals and the availability of a large number of organic linkers that has led to the synthesis of an increasing number of elegant and intricate functional structures with nanosized dimensions. The structural outcome of the synthesis of these supramolecular assemblies is largely dependent on the nature of the metal ions and ligands. From a design point of view, the ligand is arguably the 
most important feature, due to its topological components and binding abilities, which determine the size, geometry, stability and functionality of the resulting architecture. This, combined with the predictable and welldefined coordination geometries of transition metals, conferes to these metallo-supramolecules some advantages over traditional organic receptors, ${ }^{[26-28]}$ which often require highly sophisticated multistep synthetic procedures for achieving similar goals.

\subsection{Coordination-driven self-assembly}

Coordination-driven self-assembly ${ }^{[29]}$ is the most widely used approach for the design of metal-based supramolecules. Coordination-driven self-assembly allows a greater control over the design of two- (2D) and three-dimensional (3D) architectures by capitalizing on the predictable nature of the metal-ligand coordination sphere and ligand lability to encode directionality. The greater directionality offered by metal-coordinative bonding compared to weak electrostatic and $\pi-\pi$ stacking interactions, or even hydrogen bonding, makes that coordination-driven self-assembly represents an effective alternative compared to the classical organic route. ${ }^{[17}$, $19,27,30-34]$

\subsection{Supramolecular Coordination Complexes (SCCs)}

Coordination-driven self-assembly leads to the formation of Supramolecular Coordination Complexes (SCCs). ${ }^{6,}$ 27, 34-42] SCCs are discrete constructs, typically obtained by mixing soluble metal and ligand precursors that spontaneously form metal-ligand bonds to generate a single 
thermodynamically favored product. Their well-defined cavities make them suitable for guest binding. ${ }^{[43-46]}$ SCCs are often referred to as "molecular flasks" ${ }^{[47]}$ because they often show well-defined nanoscopic cavities making them potentially useful for diverse applications, such as molecular recognition, ${ }^{[13,48-49]}$ the stabilization of highly reactive species, ${ }^{[50]}$ pharmacyas drug delivery/release vectors- ${ }^{[51-53]}$ or even in catalysis due to the enhancement of reactivity produced in confined spaces. ${ }^{[54-58]}$

\subsubsection{Werner-type SCCs}

Since the earlyest examples, the field of SCCs has been largely dominated by the use of Werner-type linkers (Scheme 3), ${ }^{[24,49,59-61]}$ because this type of supramolecular architectures is often constructed using N-, P- or O-donor linkers. Several key reviews on the field of Werner-type SCCs have already been published. ${ }^{[15,17,21,27,33-34,40-41,62-67]}$ A pioneer example of macrocycles formed by coordination-driven self-assembly was described by Verkade and co-workers as early as in 1983. ${ }^{[68]}$ By reacting a diphosphine bridging ligand with $\mathrm{Cr}$, Mo or $\mathrm{W}$ carbonyl precursors, a series of metallosquares were obtained (1, Scheme 3). Then Fujita ${ }^{[69]}$ and Stang ${ }^{[70]}$ described examples of rationally designed supramolecular squares of $\mathrm{Pd}$ and Pt. The structure reported by Fujita ${ }^{[69]}$ (2, Scheme 3) can be described as a tetra-metallic palladium-cornered square with four 4,4'-bipyridil units that link the four metal fragments. After the publication of these seminal contributions, various methodologies for the rational design of polygons, polyhedra, prisms and cylinders, were developed by several authors, from which Stang, ${ }^{[28,71-72]}$ Raymond, ${ }^{[73-74]}$ Fujita, ${ }^{[15]}$ Mirkin $^{[36,75]}$ and Nitschke ${ }^{[19,}$ ${ }^{21,76]}$ have probably reported some of the most important contributions. 

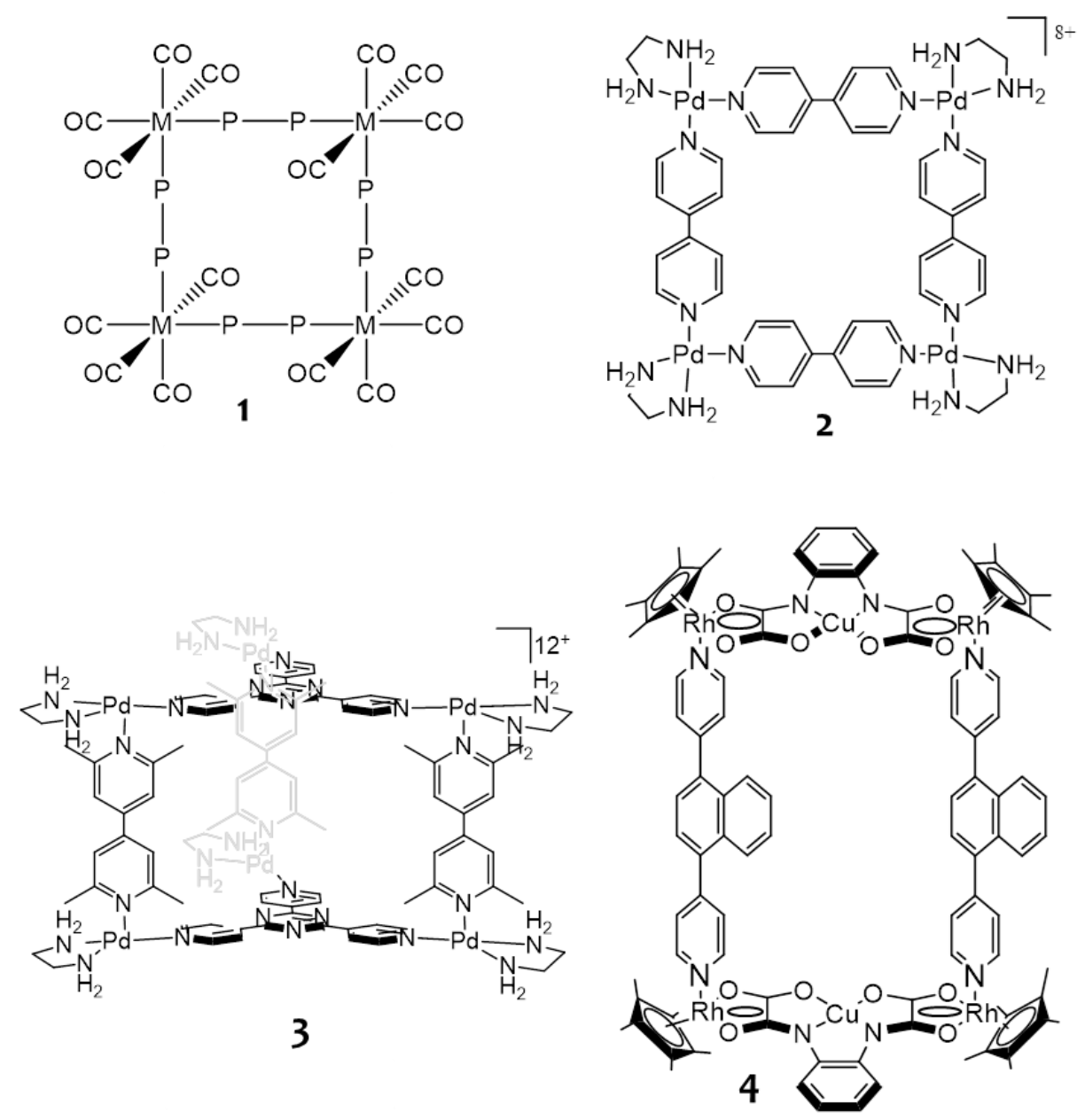

Scheme 3: A selection of representative examples of SCCs.

From the composition point of view, various metal fragments have demonstrated to be suitable for the metal-directed self-assembly of supramolecular architectures. For example, diphosphines and diamine complexes of $\mathrm{Pt}$ and $\left.\mathrm{Pd},{ }^{[15,} 28-29,31,77\right]$ polynuclear rhenium tricarbonyl complexes, ${ }^{[78-79]}$ or metal-metal bonded cationic complexes $(\mathrm{M}=\mathrm{Rh}$, Mo), ${ }^{[80]}$ have been used by many groups. 


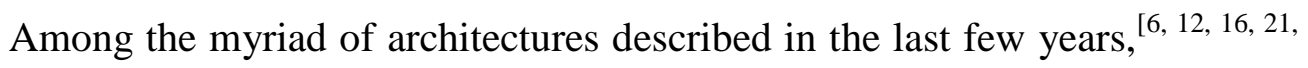
$29,36,40,61-62,75,81-84]$ those using half-sandwich metal complexes as nodes of the supramolecular structures have attracted great attention. ${ }^{[85-87]}$ For example, over the las ten years, Jin and co-workers have focused their efforts into the preparation of multiple macrocycles, prisms and boxes from Ir, Rh (4, Scheme 3) and Ru-based half-sandwich units. ${ }^{\left[{ }^{87-89]}\right.}$ These supramolecular systems were designed on the assumption that $\eta^{5}-\mathrm{Cp}^{*}$ (for Ir and $\mathrm{Rh}$, as in $\mathbf{5}$, Scheme 4) or $\eta^{6}$-arene (for $\mathrm{Ru}$, as in $\mathbf{6}$ ) serve a a three coordinate ligands, so that the metal centre adopts a six-coordinate geometry, which is filled by the bridging $\mathrm{O}-, \mathrm{Cl}-$ or $\mathrm{N}$ - donor ligands to afford the two- or three dimensional architectures via variation of the ligand 'edges'.

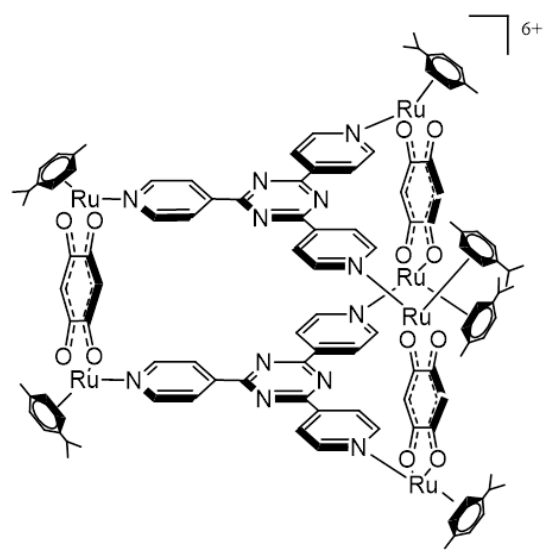

5

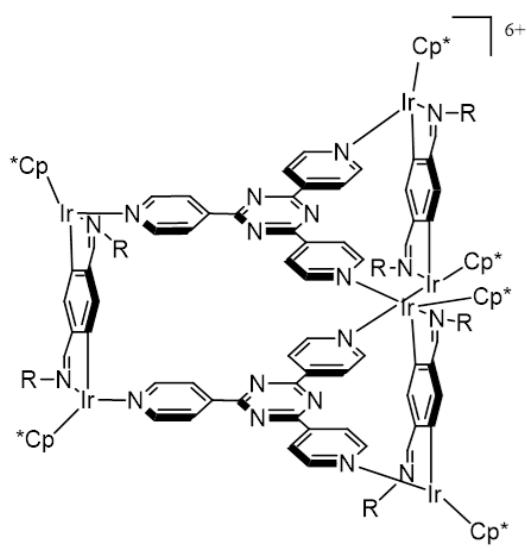

6

Scheme 4: Selected example of SCC bearing two tripyridyl triazine (tpt) linkers The trigonal prismatic assemblies are composed by six metal ions on the corners of the assembly, iridium for $\mathbf{5}$ and ruthenium for $\mathbf{6}$.

Ruthenium metallocages have also represented an interesting subclass of SCCs. ${ }^{[90]}$ Therrien and coworkers have reported a large number of Ru-based SCCs,${ }^{[90-94]}$ from which an interesting example (6) is depicted in Scheme 4. ${ }^{\left[{ }^{[2]}\right.}$ This trigonal prismatic assembly contains two types of Werner-type 
ligands, namely three 2,5-dihydroxy-1,4-benzoquinato panels and two tris(4-pyridyl)triazine linkers. The large inner cavity was first used for the encapsulation of square planar metal complexes with anticancer activity, ${ }^{[92]}$ and then for trapping large organic aromatic molecules, such as polycyclic aromatic hydrocarbons (PAHs). ${ }^{[91,95]}$

An interesting type of 3D metallosupramolecular assemblies are those using porphyrin-based ligands. These porphyrin linkers, when bound to a central metal cation, provide a binding site in the centre, which is pointing towards the center of the cavities of the cages. ${ }^{[96-101]}$ Also important is that the porphyrin-based ligands constitute the perfect scaffolds to tetragonal architectures, which are otherwise difficult to achieve. Some interesting examples on the use of metal-porphyrins in the construction of metallosupramolecular assemblies were reported by Nitschke and coworkers. ${ }^{[102-104]}$ For example, Scheme 5 shows the preparation of a watersoluble cubic-shaped porphyrin-based supramolecular capsule with a hydrophobic cavity (7), which was used for the encapsulation of organic guests, such as polycyclic aromatic hydrocarbons, and complex organic drugs, which otherwise could not be brought into water. ${ }^{[102]}$

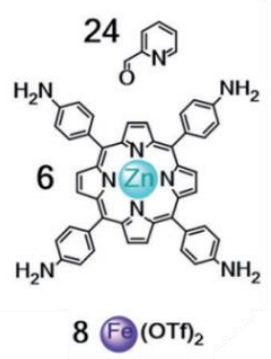

Self-Assembly

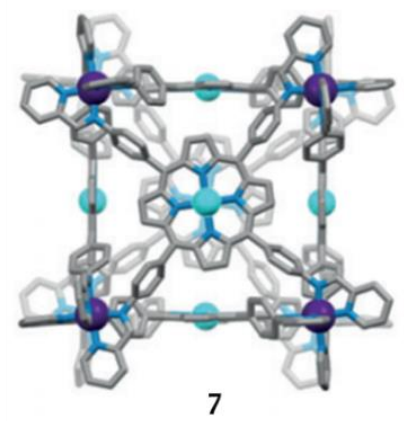

Scheme 5: Porphyrin-based SCC reported by Nitschke and co-workers obtained via coordination-driven self-assembly. Image of the X-ray diffraction structure taken from reference $^{[102]}$ 
Ribas and co-workers also published a series of interesting porphyrin-based tetragonal cages, which they used for the encapsulation of fullerenes. ${ }^{\text {[105-107] }}$ By using a 'sponge-like' molecular cage, they were able to design a washing-based strategy to exclusively extract pure $\mathrm{C}_{60}$ from a mixture of fullerenes of different sizes. ${ }^{[105]}$ In a more recent contribution, the same group used the same type of 'supramolecular fullerene sponge', for the regioselective functionalization of $\mathrm{C}_{60 .}{ }^{[107]}$ This study constitutes a unique example of how the molecular flask can be used as a template to fully direct the selectivity of an otherwise unselective reaction. In this case, the regioselectivity is strictly dictated by the four cross-shaped windows in the tetragonal prismatic cage (8), which is used as a mask to control the reactivity and equatorial regioselectivity of Bingel-Hisch cyclopropanation reactions of the confined $\mathrm{C}_{60}$ molecules, as depicted in Scheme 6.

\section{3-step process:}

A) Encapsulation of C60 inside Complex 8 (Supramolecular Mask)

B) Selective Cyclopropanation of (60 with 4 eq of diethyl bromomalonate (R)

C) Release functionalized C60 as pure isomer outside Complex 8

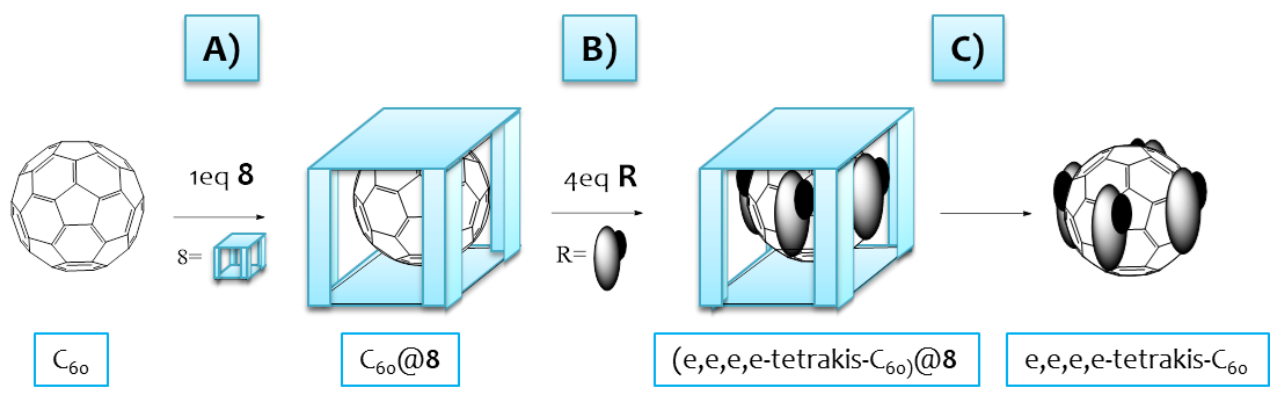

Scheme 6: Schematic representation of the regioselective functionalization of $\mathrm{C}_{60}$ with diethyl bromomalonate by using a tetragonal prismatic cage that behaves as a supramolecular mask by Ribas et al. ${ }^{[107]}$ 
Together with the geometries displayed by the supramolecular assemblies described above, tetrahedral architectures have also been a matter of continuous interest. ${ }^{[108]}$ The first tetrahedral metallosupramolecular structure was described by Fujita and co-workers in 1995. ${ }^{[109]}$ This tetrahedral architecture was obtained by using a trigonal planar tris-pyridyl ligand as scaffold in combination with $\left[\mathrm{Pd}\left(\mathrm{NO}_{2}\right)_{2}(\mathrm{en})\right]$ (en = ethylene-diamine) in a 3:2 (Pd:ligand) stoichiometry. It could be simplified as a octahedral motif with the tris-pyridyl ligands located only in four of the eight sides of the octahedron. The resulting supramolecular structure has a large central void, which can accommodate large guest molecules, such as adamantly carboxylate. The use of other palladium (II) $(\mathbf{9}, \mathbf{1 0})$, platinum (II) ${ }^{[110]}(\mathbf{1 1})$ or even $\mathrm{Ru}(\mathrm{II})^{[111]}$ (12) sources afforded a family of cages with the same tetrahedral structure (Scheme 7).
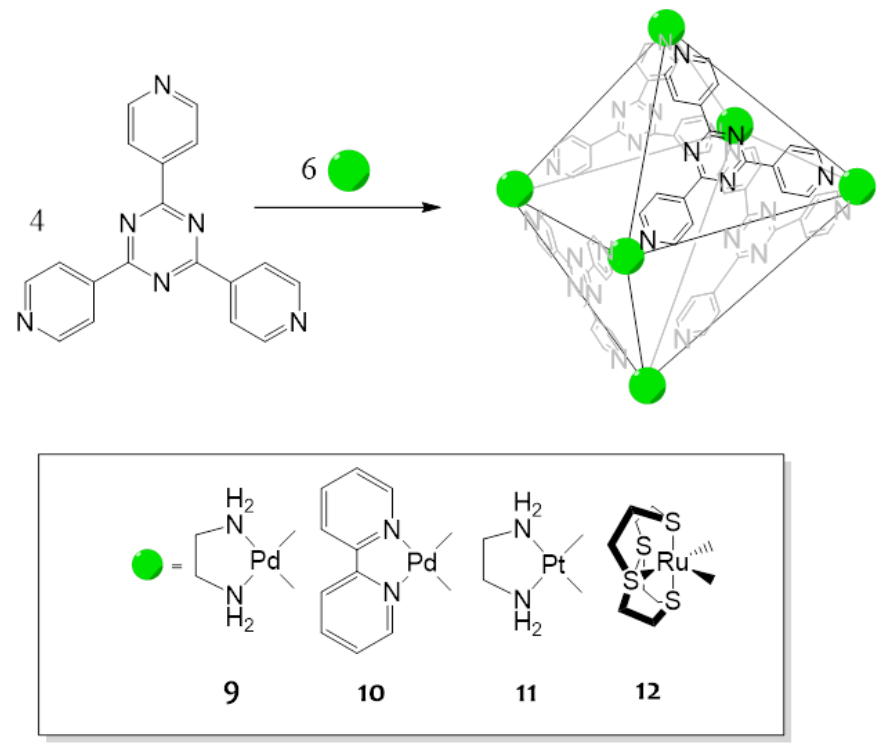

Scheme 7: Metal-cornered SCCs with "tetrahedral" symmetry decorated with different metal fragments reported by Fujita. ${ }^{[109-111]}$ 


\subsection{Host-Guest Chemistry}

Due to the presence of cavities with well-defined sizes and shapes, HostGuest chemistry is arguably the most important feature of SCCs. ${ }^{[43-46]}$ The presence of a void space in SCCs imparts a wide varity of applications, which include their use as flasks for chemical reactions, ${ }^{[47}$, 55, 112-114] containers for reactive chemical species, ${ }^{[115-116]}$ hosts for aromatic stacks, ${ }^{[117-120]}$ sensors, ${ }^{[121-123]}$ and as transport vehicles for molecules with medical properties ${ }^{[35,124-126]}$

Host-Guest chemistry is considered as a sub-discipline within supramolecular chemistry, and it can be defined as the chemistry involving the interactions between a large receptor with a cavity (host) able to harbor inside a smaller molecule of interest (guest) (Scheme 8).

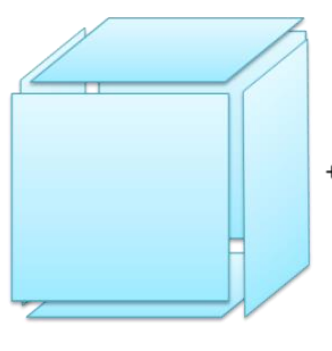

Host

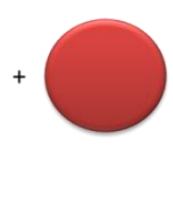

Guest

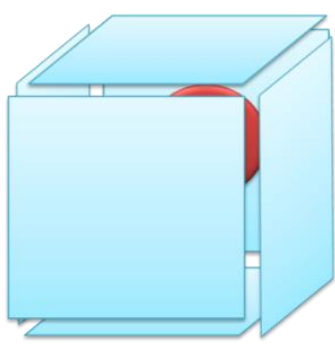

Host-Guest

Scheme 8: Schematic representation of a Host-Guest System

A large number of reviews and accounts have been published regarding this the use of supramolecular compounds used as receptors for the encapsulation of guests of interest. ${ }^{[73,82,106,127-129]}$ For example, Raymond described the reversible guest exchange mechanisms in supramolecular host-guest systems. ${ }^{[73]}$ Chifotides and Dunbar described the use of host-guest systems involving anion- $\pi$ interactions. ${ }^{[130]}$ Schneider and Yatsimisky published a 
tutorial review aimed to provide a theoretical approach for the rational design of selective host-guest systems. ${ }^{[82]}$ In connection with metallosupramolecular chemistry, Frischmann and MacLachlan were the first ones to use the term "metallocavitand" to refer to multimetallic complexes where the metal coordination is necessary for cavity formation. ${ }^{[131]}$

\subsubsection{Receptors for Polycycic Aromatic Hydrocarbons (PAHs)}

Among all the examples reported in the literature describing supramolecular cages ${ }^{[132]}$ behaving as receptors for organic substrates, we will focus our attention on the systems used for the recognition of two types of guests: fullerenes and Polycyclic Aromatic Hydrocarbons (PAHs), since these have been the ones used in the research of this $\mathrm{PhD}$ Thesis.

Polycyclic Aromatic Hydrocarbons (PAHs) ${ }^{[133-135]}$ are organic compounds formed by two or more fused aromatic rings. Low molecular weight PAHs ranging from naphtalene $\left(\mathrm{M}_{\mathrm{w}}=128.16\right)$ to coronene $\left(\mathrm{M}_{\mathrm{w}}=300.36\right)$ are considered hazardous materials that have gathered significant environmental concern. ${ }^{[136-139]}$ Unsubstituted lower PAHs (2-3 rings) exhibit acute toxicity, while many of the 4- to 7-ring PAHs are less toxic but carcinogenic to a variety of organisms. Therefore, there is a great interest in developing host molecules for PAH detection.

Most PAHs show a planar structure (Scheme 9), although they can be modified with the introduction of five member rings, which provide curve geometries, such as the bowl-shaped structure of corannulene. The number of aromatic rings that compose the $\mathrm{PAH}$ molecule not only determines its size, but also the number of $\pi$-electrons that are available for $\pi$-stacking with a potential receptor (host), and therefore this highly determines their 
different binding affinities. ${ }^{[43,140-142]}$

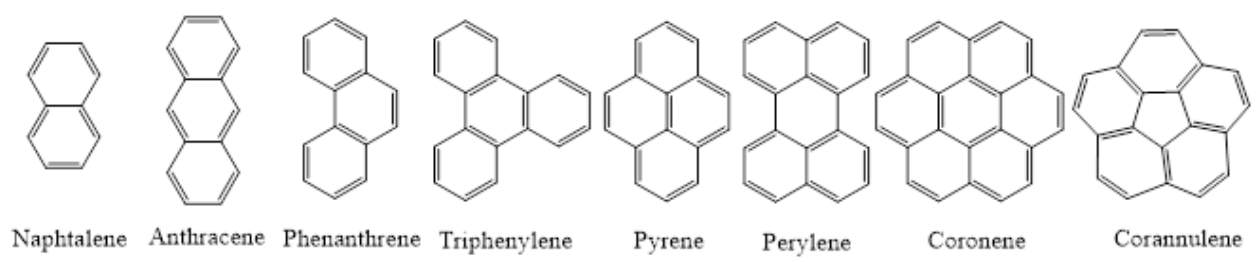

Scheme 9: Most common Polycyclic Aromatic Hydrocarbons (PAHs).

A large number of organic hosts have been used for the recognition of PAHs, among which, those reported by Stoddart and co-workers lie among the ones that have shown larger binding affinities. ${ }^{[43,66,141,143]}$ During the last 15 years, a large numer of examples of SCCs have been used for the encapsulation of PAHs, $\left.{ }^{[44,} 90,118,144-156\right]$ but the search for more efficient metallocage-based receptors continuous to be a challenge because the binding affinities found are still far from those shown by the most efficient pure organic-based systems.

One interesting type of SCC-based PAH-receptors were the ones explored by Quintela and Peinador (13, Scheme 10), which consisted of rectangle-like metallacycles containing either Pd(II) or Pt(II) nodes. ${ }^{[151-152]}$ These receptors were used for the encapsulation of naphthalene, carbazole, pyrene, and benzo[a]pyrene. The authors made special emphasis on exploring the sizecomplementarity between the guests and the internal cavities of the metallacycles, and they found evidences of $\mathrm{C}-\mathrm{H} / \pi$ interactions that stabilize the inclusion complexes and give predictable binding geometries. Some further findings made by the same authors were published in a review article in 2014. ${ }^{[155]}$ Another interesting example was described by Therrien and coworkers (14), who reported a series of hosts ${ }^{[90-91,93,157]}$ capable of harboring aromatic guests such as pyrene, fluoranthene, benzo[e]pyrene, triphenylene, 
or coronene. Nitschke and co-workers demonstrated that the incorporation of large aromatic panels into the structures of SCC provides more effective hosts for the encapsulation of planar polyaromatic guests (15). ${ }^{[4]}$ Scheme 10 shows a selection SCCs used as PAH-receptors.

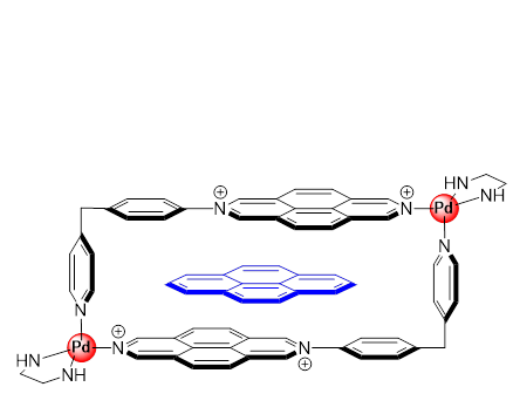

13
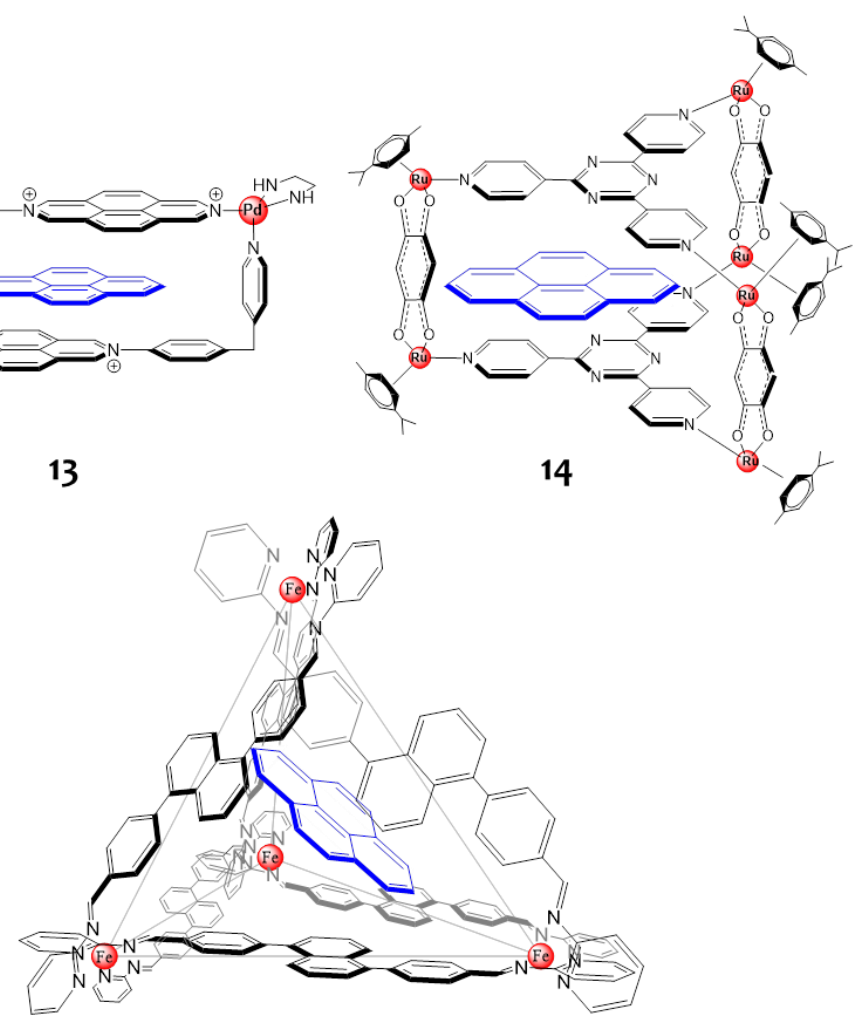

15

Scheme 10: Selected examples of PAHs-receptors with a pyrene encapsulated.

Binding of multiple guests by a single receptor (Scheme 11) can lead to new modes of host-guest interactions that may be translated into interesting applications. For example, receptors capable of intercalating multiple stacks are very challenging, because enabling discrete $\pi$-stacks can facilitate the study of the charge transport at the molecular level. In general, the number 
of planar guest molecules that can be brought inside a molecular cage depends exclusively on the cavity height, and this is exclusively determined by the pillar length.
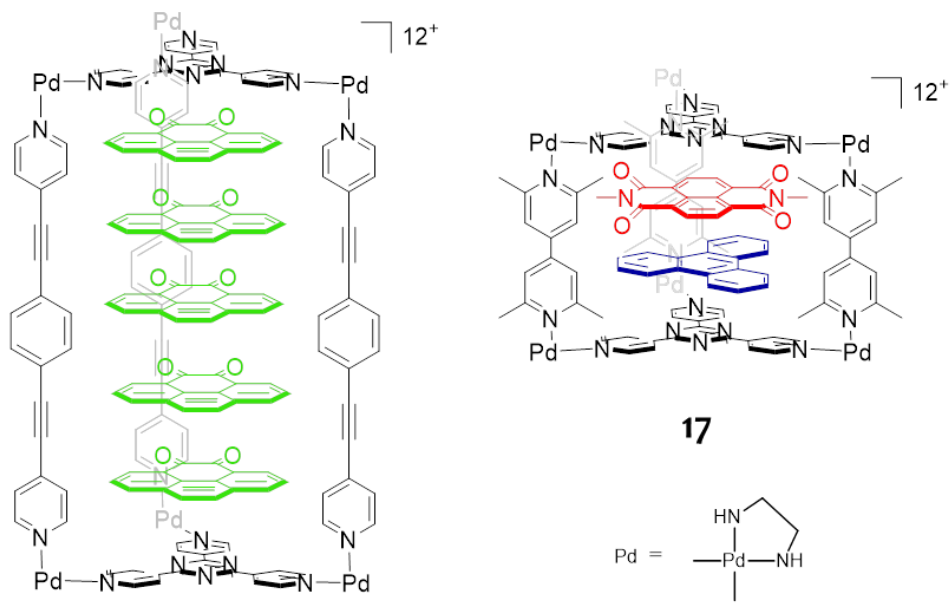

16

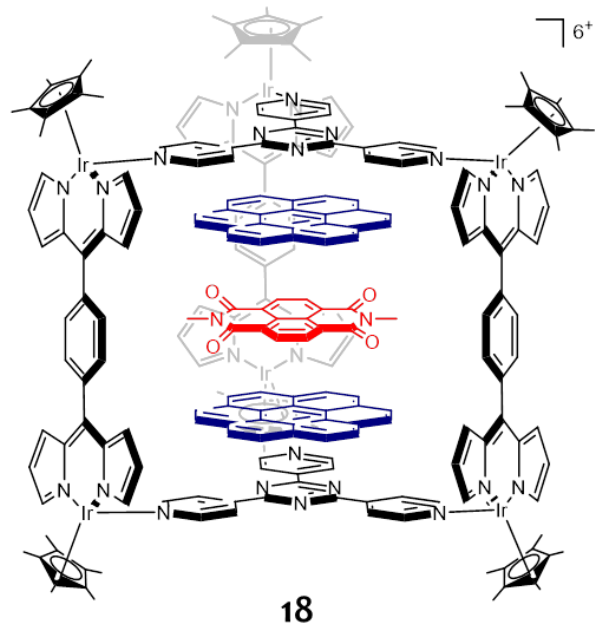

Scheme 11: Selected examples of metallocages used for multiencapsulation of PAHs.

In 2010, Fujita et al. demonstrated how by modifying the length of the linker, the SCCs receptor can host a variable number of molecules, ranging from 2 to up to 5. Scheme 11, shows an example in which the receptor (16) 
hosts up to 5 molecules of pyrene-4,5-dione. ${ }^{[158]}$ Other examples of multiencapsulation of PAH have been described in the last few years, ${ }^{[158-161]}$ Of particular interest are those examples in which the receptor is able to encapsulate different PAHs, as in the examples reported by Fujita ${ }^{[160]}$ (17) and $\mathrm{Chi}^{[161]}(\mathbf{1 8})$, both of them depicted in Scheme 11.

Sometimes the encapsulation of heteroguests may produce important structural transformations that otherwise would be unnoticed. For example, in a very interesting contribution, by using the palladium-based trigonal prismatic cage 19, Fujita and co-workers showed how the cage is able to simultaneously encapsulate corannulene and N,N'-dimethyl naphthalenetetracarboxydiimide (NTCDI) (Scheme 12). ${ }^{[162]}$ Interestingly, upon encapsulation, the molecule of corannulene is flattened, as observed form the bowldepth of the encapsulated molecule of corannulene $(0,54 \AA)$, compared to the depth shown by the same molecule in the free state $(0.87$ $\AA$ ).

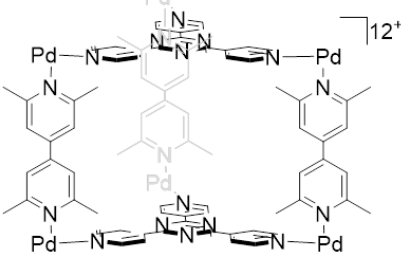

19

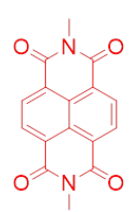

G1

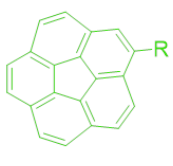

G2

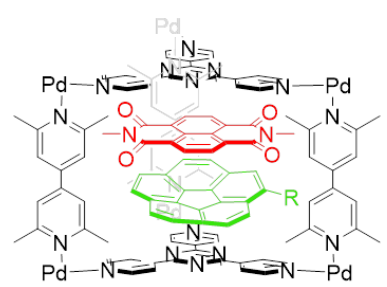

$\left(G_{1}+G_{2}\right) @ 19$

Scheme 12: In this Host-Guest system, the palladium box-shaped cage (Host) encapsulates NTCDI (G1, Planar Guest) and corannulene (G2, Curved Guest). Palladium node in Complex 19 constitutes the same ethylenediamine palladium node shown in Complexes 16 and 17, depicted in Scheme 11. 


\subsubsection{Metallocages as fullerene hosts.}

Fullerenes can be considered as all-carbon spheroidal PAHs. Fullerenes can be easily extracted from carbon soot, but the development of an efficient strategy for its purification remains challenging task, especially for those fullerenes with higher molecular weight than $\mathrm{C}_{70}$. As an alternative, several research groups have proposed the use of supramolecular receptors for the selective extraction and purification of fullerenes, and this is actually one of the main reasons of the increasing interest in host:guest studies with fullerenes in the last few years. ${ }^{[163]}$

Among the fullerene receptors studied, those based on cyclodextrines, ${ }^{[164]}$ calixarenes, ${ }^{[165]}$ porphyrins, ${ }^{[98]}$ or metaloporphyrins, ${ }^{[166]}$ lie among the most efficient ones. In addition to all those mentioned above, corannulene is among the most efficient binding units to be incorporated in synthetic molecular receptors for fullerenes. This is due to the shape complementarity that exists between the shallow concave cavity of corannulene and the convex surface of the fullerenes. ${ }^{[167]}$ Several synthetic receptors combining two or more corannulene binding units were recently synthesized. ${ }^{[168]}$ Some of these fullerene-receptors, which were named 'buckycatchers', showed remarkable affinities for fullerene binding in solution (Scheme 13). ${ }^{[18,169-175]}$

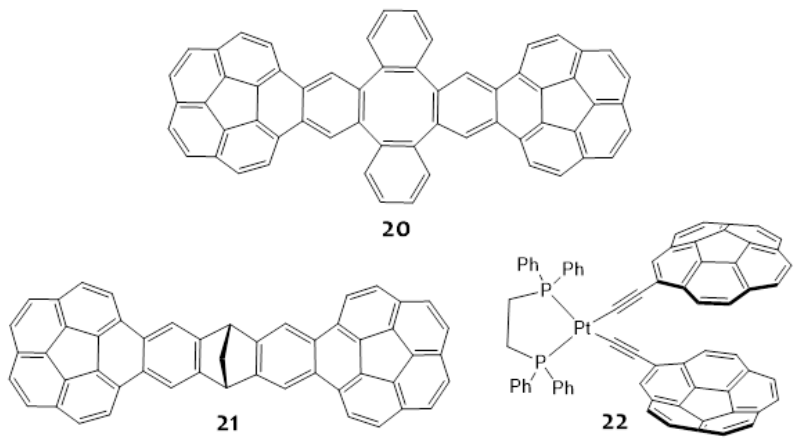

Scheme 13: Selected examples of corannulene-based fullerene receptors or 'buckycatchers'. 
In this regard, at Universitat Jaume I, the Organometallic and Homogeneous Catalysis group QOMCAT, from now on), also developed a fullerene receptor by using a di-Au(I) compound with a corannulene-di-N-heterocyclic carbene ligand (23). This metal-based receptor showed excellent binding affinity with fullerene- $C_{60}$, producing guest:host complexes of $1: 3$ stoichiometry, as shown in Scheme 14. ${ }^{[176]}$
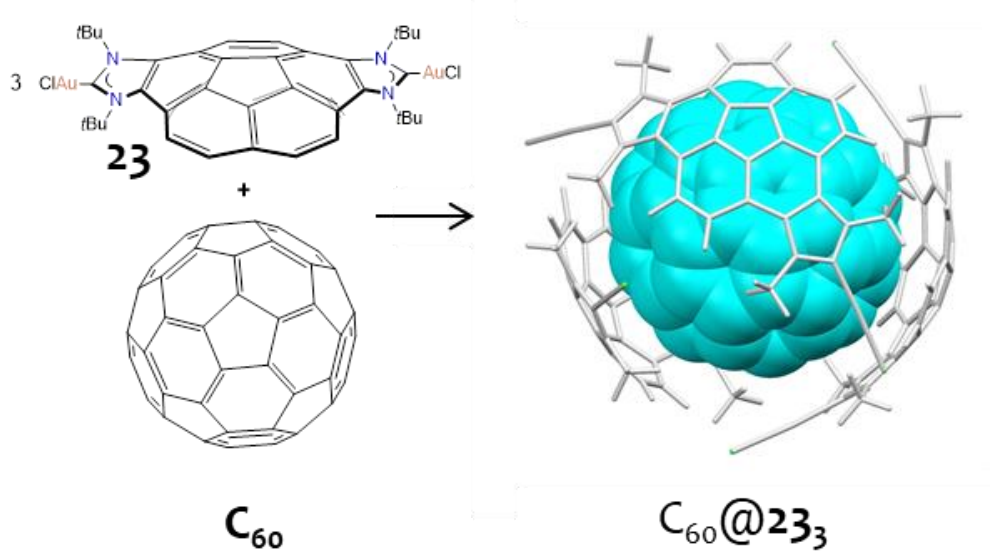

Scheme 14. Corannulene-di-NHC-based receptor developed by the QOMCAT group at UJI

SCCs have also been widely used for hosting fullerenes. Among the SCCs used for this purpose, those based on Pd(II)-pyridine chemistry are the ones that have been most widely used. ${ }^{[177-181]}$ Shinkai et al. were among the pioneering groups by reporting in 1999 a Pd-based calixarene capsule capable of expanding the size of its cavity to harbour fullerene $\mathrm{C}_{60}(\mathbf{2 4}$, Scheme 15). ${ }^{[177]}$ As mentioned above, some of the most illustrative examples of fullerene receptors are the ones described by Ribas and co-workers, which consist of porphyrin-based, sponge-like molecular cages able to encapsulate $\mathrm{C}_{60}, \mathrm{C}_{70}, \mathrm{C}_{76}, \mathrm{C}_{78}$ and $\mathrm{C}_{84 \cdot}{ }^{[105-107]}$ 
Some other interesting examples in which the host contains other metals are also worth mentioning. For example, in 2014 Yoshizawa reported a $\mathrm{Hg}$ based transformable coordination capsule/tube that was able to change its shape and size, depending on whether it encapsulated $\mathrm{C}_{60}$ or $\mathrm{C}_{70}(\mathbf{2 5}$, Scheme 15). ${ }^{[182]}$ Nithscke and co-workers developed a $\mathrm{M}_{8}^{\mathrm{II}} \mathrm{L}_{6}$ cage $(\mathrm{M}=\mathrm{Fe})$ with electron-deficient walls that was able to encapsulate $\mathrm{C}_{60}$, and enabled the [4+2] cycloaddition of fullerene with anthracene to yield the bisadducts under mild conditions. ${ }^{[103]}$

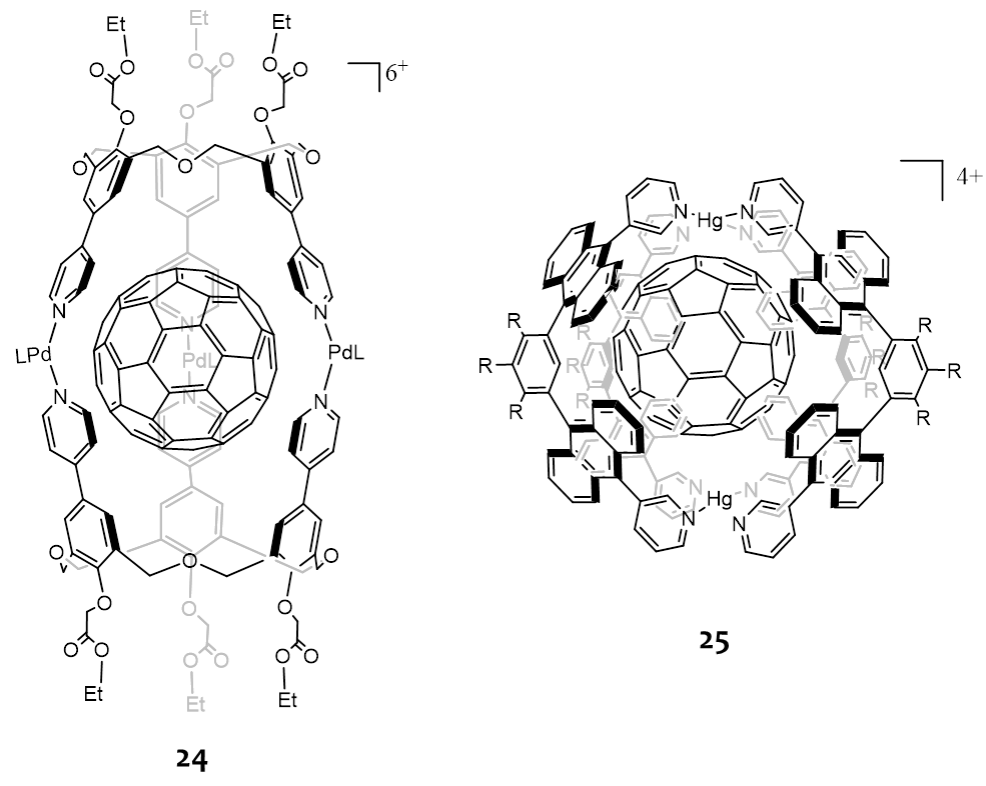

Scheme 15. Selected example of Pd-based (24) and Hg-based (25) SCC acting as Fullerene receptors. 


\section{Supramolecular Organometallic Compounds (SOCs)}

\subsection{Background}

As already mentioned in the sections above, metallosupramolecular chemistry is clearly dominated by the use of $\mathrm{O}-\mathrm{N}$ - and P-donor Werner-type polydentate ligands. Only recently, organometallic ligands -largely based on poly-N-heterocyclic carbenes $(\mathrm{NHCs})^{[183-184]}$ - have allowed the preparation of a diverse type of SCCs including molecular squares, rectangles and triangles, ${ }^{[185-192]}$ cylinders ${ }^{[192-198]}$ and organometallic polymers ${ }^{[199-208]}$ (Scheme 16).

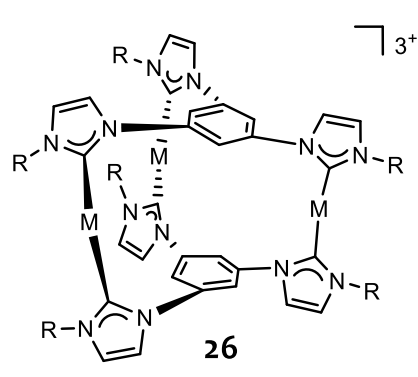

$\mathrm{M}=\mathrm{Ag}, \mathrm{Au}, \mathrm{Cu}$

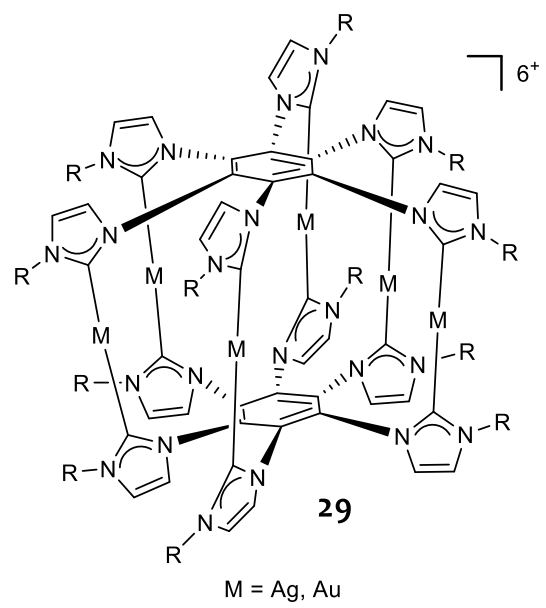

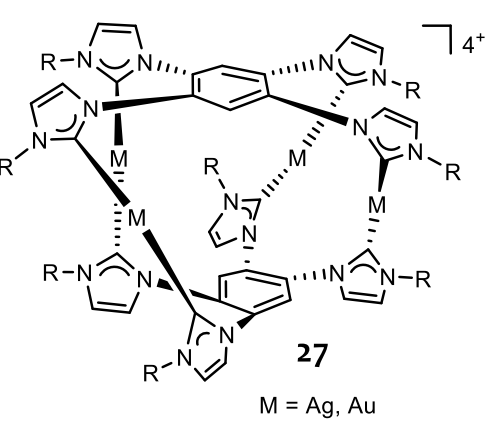

$M=A g, A u$

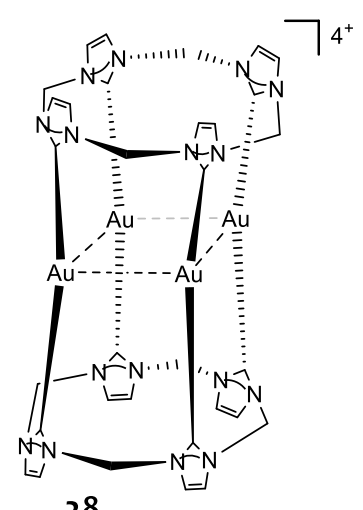

28

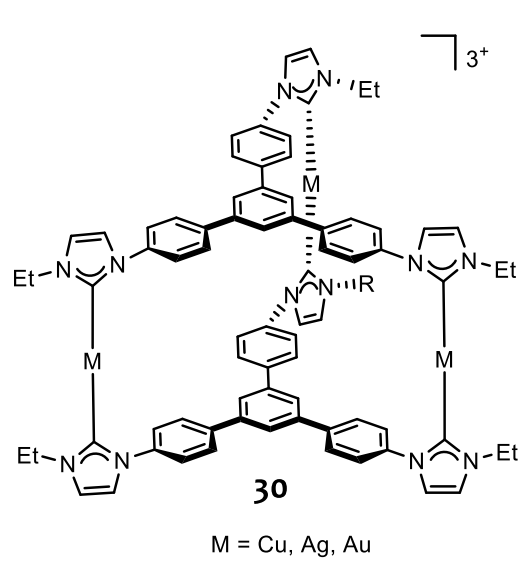

Scheme 16. Selected examples of SCCs with organometallic linkers (NHC-based) 
The term Supramolecular Organometallic Complexes (SOCs) was coined by Pöthig and Casini in 2019. ${ }^{[209]}$ Hence, Supramolecular Organometallic Complexes refer to complexes in which the carbon donor is part of the linker-node connection, and the (organic) linker is forming the organometallic bond to the metal node. This definition does not include those complexes that, while having organometallic ligands (normally $\eta^{5}-\mathrm{Cp}$ or $\eta^{6}$-arenes), these are part of the metal nodes, and therefore are not decisive for the formation of the organometallic assembly. Examples of SOCs, include metallosupramolecular arrangements with organometallic linkers, such as bis-alkenyls $(\mathbf{3 1}),{ }^{[210-211]}$; diphenyl $(\mathbf{3 2})^{[212]}$ and alkynyls $(\mathbf{3 3}),{ }^{[213-217]}$ some of which are depicted in Scheme 17.

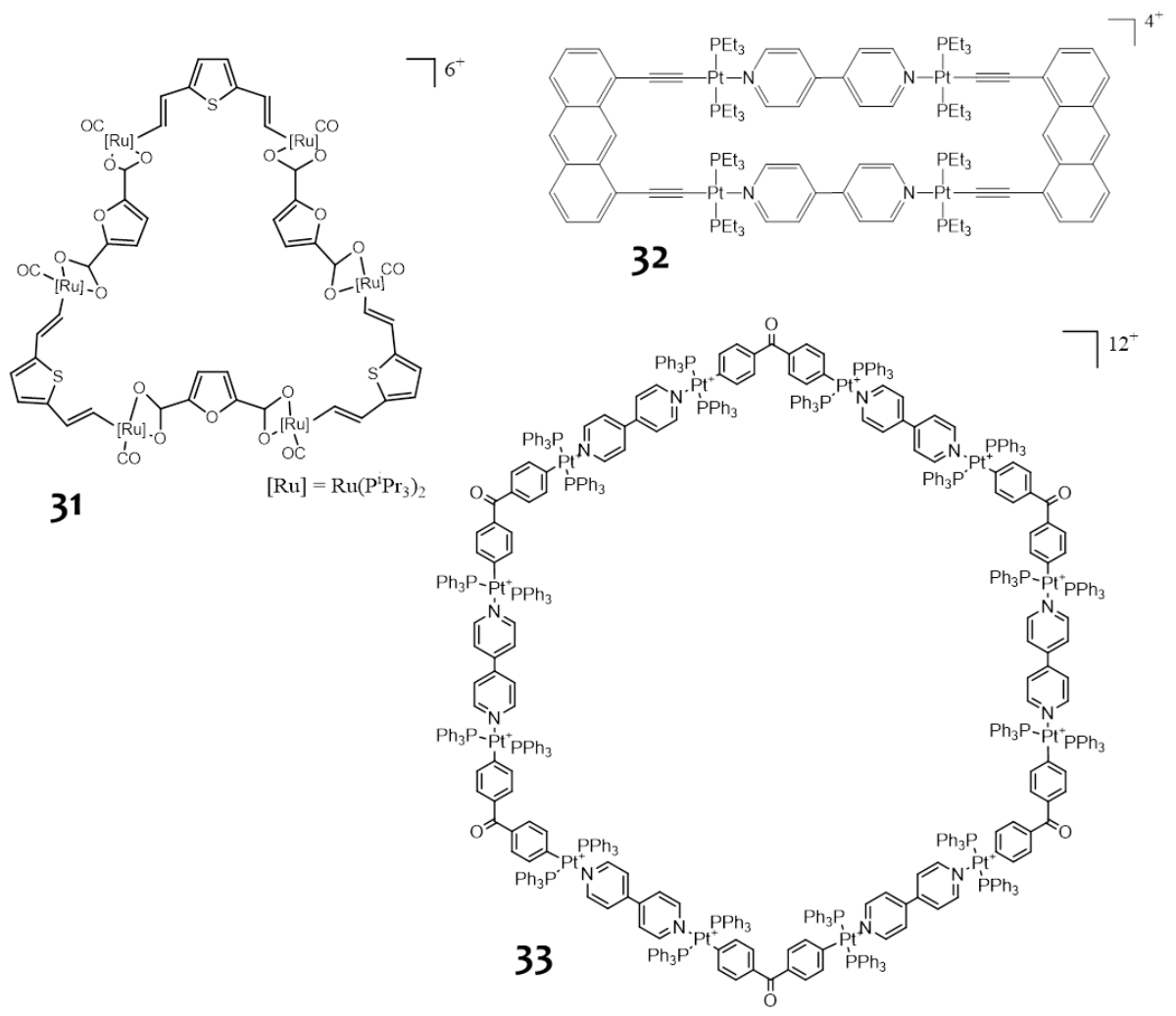

Scheme 17. Selected examples of SOCs bearing bis-alkenyl (31), diphenyl (32) and alkynyl (33) linkers 
The rapid development of SOCs has grown parallel to the development of multidentate NHC ligands, which benefited from the contributions of researchers such as Hahn, ${ }^{[218]}$ Bielawski $^{[203]}$ and Peris. ${ }^{[183]}$ This rapid growth of the chemistry related to SOCs is also exemplified by the publication of two recent key reviews by Hahn and co-workers. ${ }^{[219-220]}$

The early examples of NHC-based SOCs referred to supramolecular assemblies based on polydentate NHC ligands bound to group 11 metals $(\mathrm{Cu}, \mathrm{Ag}, \mathrm{Au}){ }^{[221-225]}$ The reason for this, is that these metals often display linear coordination modes that facilitate the trans-coordination of the NHC ligands, therefore forming assemblies, in which the metals are sandwiched in between the two polydentate NHC ligands. However, during the last ten years, several planar polyconjugated poly-NHC ligands have facilitated the formation of a variety of structures in which the supramolecular assemblies can contain metals other than $\mathrm{Cu}, \mathrm{Ag}$ and $\mathrm{Au}$. Such ligands are the Janus-diNHCs and trigonal planar tris-NHCs displayed in Scheme 18. At this point, it is convenient to recall that a Janus-based NHC-ligand, refers to a bidentate bridging ligand that is able to bind to two different metal fragments in a facially-opposed manner.

From the examples of poly-NHC ligands shown in Scheme $18,{ }^{[226-230]}$ the benzo-di-imidazolylidene ligand described by Bielawski in 2005 (35), ${ }^{[203]}$ was the first one to demonstrate its suitability for the preparation of organometallic-based supramolecular assemblies. The use of these di-NHC ligands allows the synthesis of supramolecular assemblies whose dimensions may vary from the $6 \AA$ stablished by the triazolylidene ligand $(\mathbf{3 4})^{[226]}$ to up to almost $23 \AA$ when the nanosized di-NHC with the quinoxalinophenanthrophenazine core ${ }^{[229]}$ is used (38). Parallel to the development of these facially-opposed di-NHCs, some other threefold- 
symmetry tri-NHCs, as the two ones shown in Scheme 18 (39 and 40), were also prepared. ${ }^{[231-233]}$

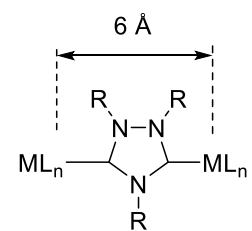

34

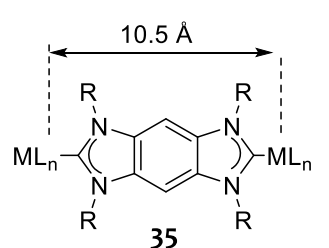

35

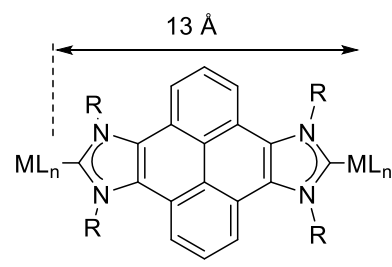

36

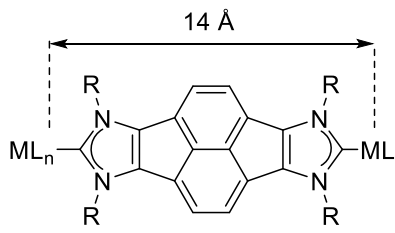

37

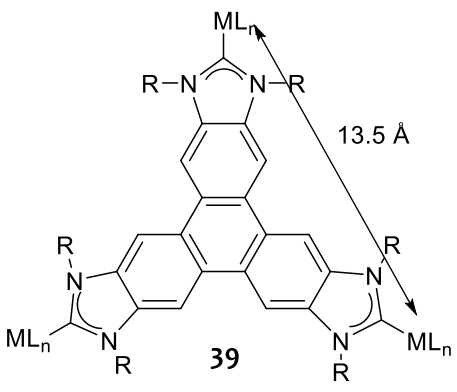

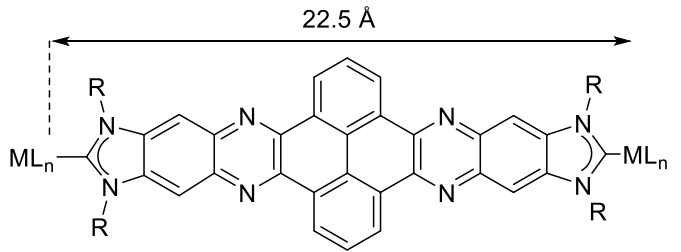

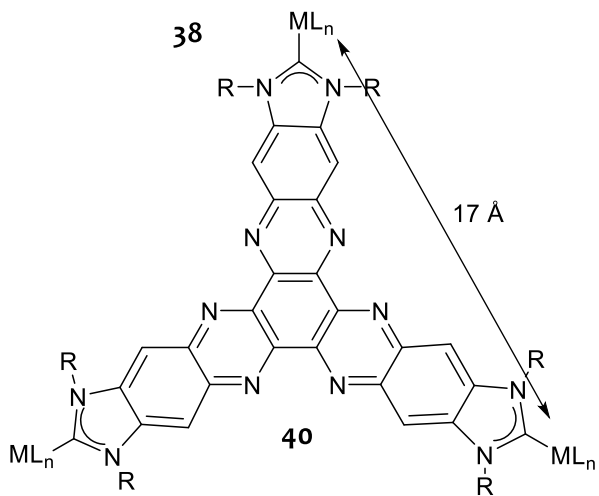

Scheme 18. Relevant available planar di- and tri-NHC ligands for the preparation of SOCs

Hahn and co-workers were the first ones to exploit the linear arrangement of Bielawski's benzo-bis-imidazolylidene ligand for the preparation of a number of square-shaped assemblies (Scheme 19) that included metals, such as, gold (41), ${ }^{[186,192,198,234]}$ iridium (43), ${ }^{[188,235]}$ platinum (42), ${ }^{[189,236]}$ palladium ${ }^{[235]}$ and nickel (44). ${ }^{[185]}$ Together with the use of this benzo-bisimidazolylidene ligand, Hahn also used a structurally similar di(NH,O)-NHC ligand for the preparation of a large number of molecular squares (42, Scheme 19). ${ }^{[188-189,236-237]}$ 

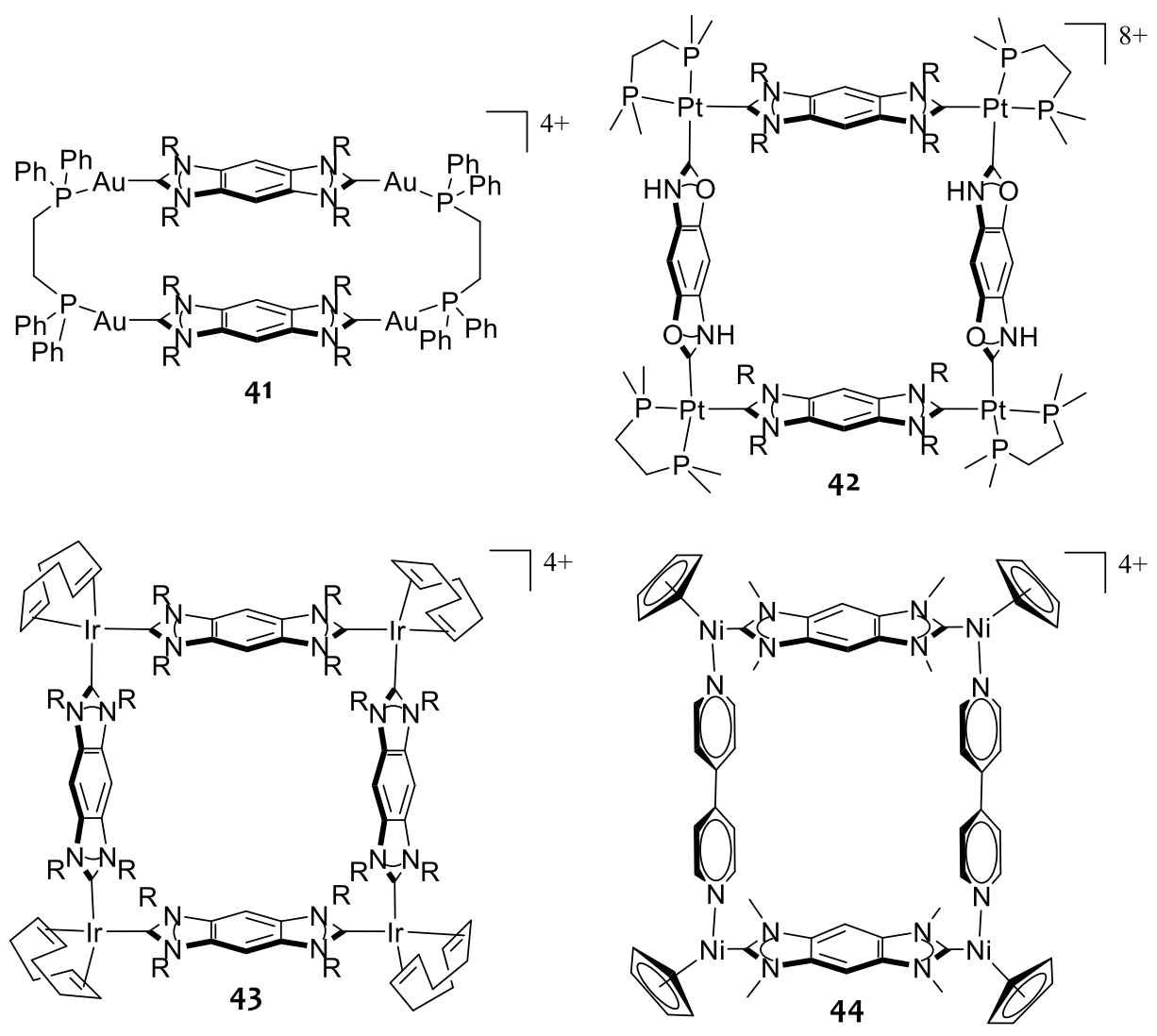

Scheme 19. Some relevant examples of organometallic-based metallosqueres, described by Hahn and co-workers

Although the number of SOCs has increased in the last few years, the number of examples of organometallic-based supramolecular assemblies that have been used for host-guest chemistry purposes is still very scarce. Some recent relevant examples of SOCs used for the encapsulation of organic substrates were described by Pöthig and co-workers. ${ }^{[209,238]}$ This group of research developed organometallic-based $\mathrm{Ag}_{8}$ and $\mathrm{Au}_{8}$ pillarplexes which were highly selective for the encapsulation of linear molecules, such as 1,8 diaminooctane, constituting a very unique case of rotaxanes. A very interesting observation is that the system (Scheme 20) can be switched 
reversibly and quantitatively to an organic imidazolium-based [3] rotaxane via a unique $\mathrm{pH}-$ dependent decoordination of the involved metal ions. ${ }^{[239]}$

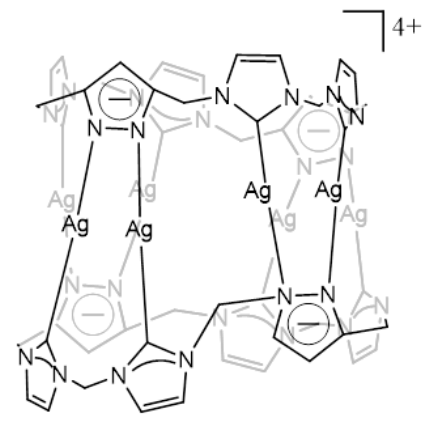

\section{Pillarplex [45]}

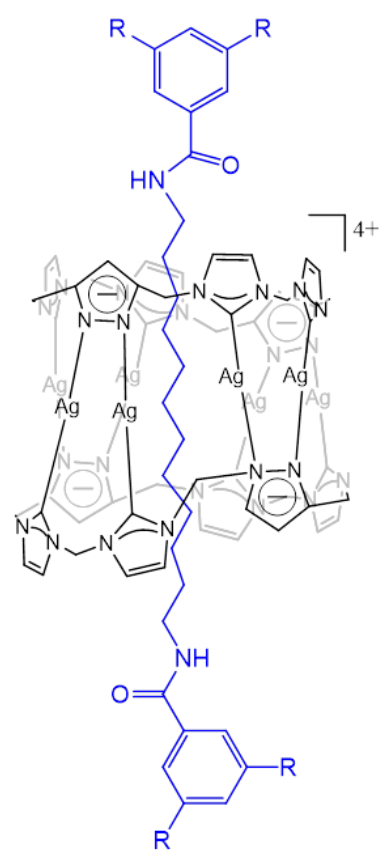

[45]Rotaxane

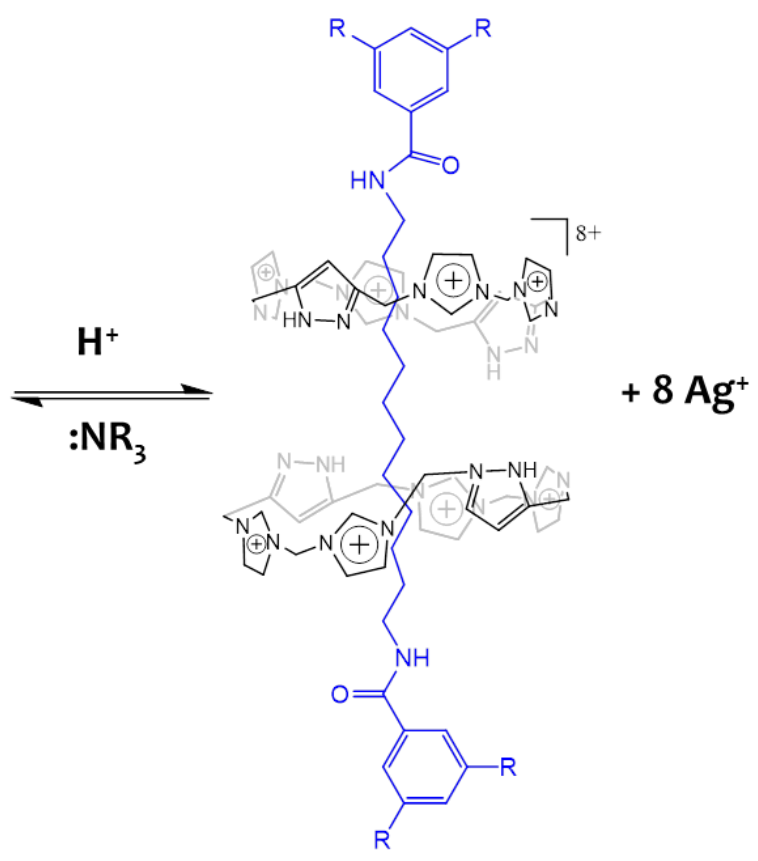

(NHC4MIC2)Rotaxane

Scheme 20. Relevant example of a Ag-based SOC (45) used in acid/base switchable rotaxane, reported by Pöthig and co-workers. It may also be observed as a Host-Guest system in which the silver anions are trapped by the imidazolium rings in order to form the pillarplex 45 . 


\subsection{SOCs developed in the QOMCAT group.}

With the accessibility to larger di- and tri-NHC planar ligands, such as those depicted in Scheme 18, Peris and co-workers from the QOMCAT group at UJI, recently developed a series of supramolecular assemblies that included several metallorectangles, ${ }^{[240]}$ metalloprisms, ${ }^{[241]}$ and twisted metallocyclophanes, ${ }^{[242]}$ as the Au-based ones that are depicted in Scheme 21 (4648). In parallel to the development of these structures, several other systems based on nickel ${ }^{[140,243]}$ and palladium ${ }^{[244-246]}$ were also developed, as will be described along the next chapters of this $\mathrm{PhD}$ Thesis.

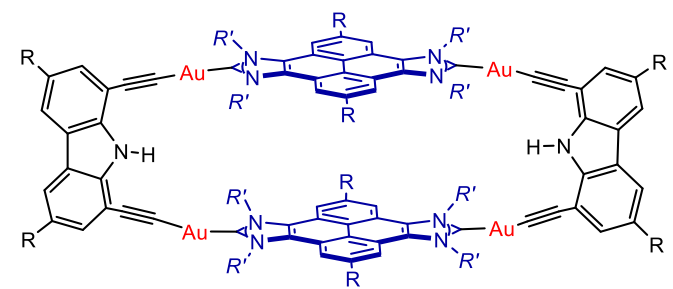

46

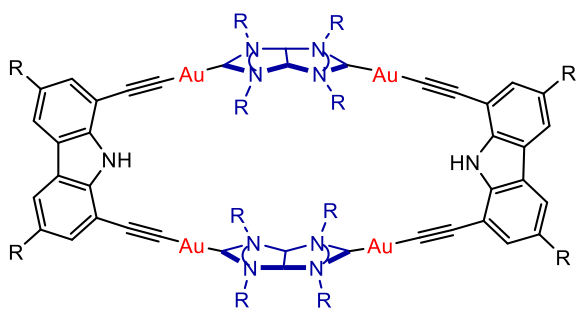

47

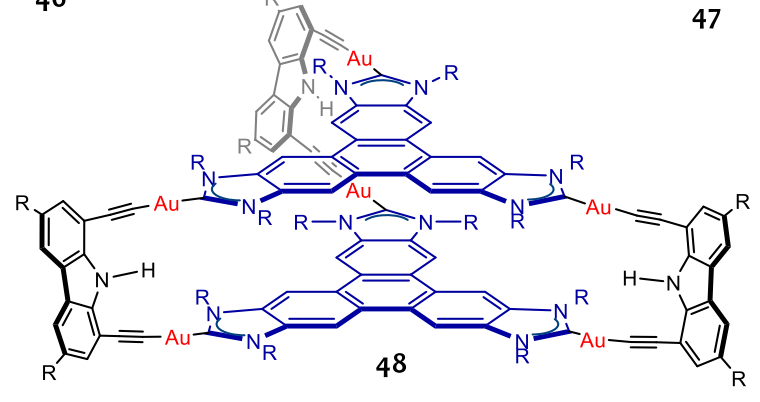

Scheme 21. Gold-based nano-sized SOCs developed in the QOMCAT-UJI group.

Interestlingly, the nanosized nature of the structures shown in Scheme 21, together with the presence of the planar polycyclic-polyconjugated panels shown in the structures of $\mathbf{4 6}$ and $\mathbf{4 8}$, made that these two structures were very effective for the encapsulation of a series of polycyclic aromatic 
hydrocarbons (PAHs). ${ }^{[240-241]}$ The large binding affinities found are ascribed to the incorporation of the two cofacial aromatic polyconjugated panels separated by almost exactly $7 \AA$, thus providing the optimum conditions for guest recognition by $\pi-\pi$ stacking interactions.

In parallel to the development of these types of supramolecular structures, the QOMCAT group also described a series of metallotweezers for the recognition of organic and inorganic substrates. At this point, it s convenient to recall that a molecular tweezer is a molecular receptor that contains two polyaromatic arms at the edges, which are bound by a more or less rigid tether. ${ }^{[247-250]}$

Tweezers with rigid linkers enabling two parallel interaction sites separated by $\approx 7 \AA$ are expected to behave as good hosts for the complexation of aromatic substrates by $\pi$-stacking interactions with the aromatic pincers, as aromatic groups stack at an interplanar distance of $\leq 3.5 \AA$. In this regard, by taking advantage of the design of a large number of NHC ligands decorated with polyaromatic functionalities, the QOMCAT group was able to design a series of gold-containing metallotweezers as the ones depicted in Scheme 22. ${ }^{[251-255]}$

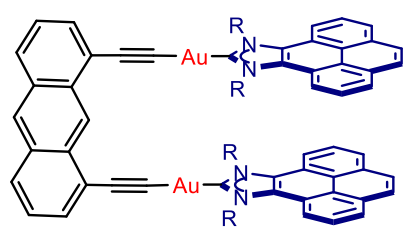

49

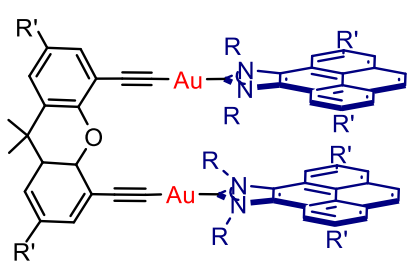

50

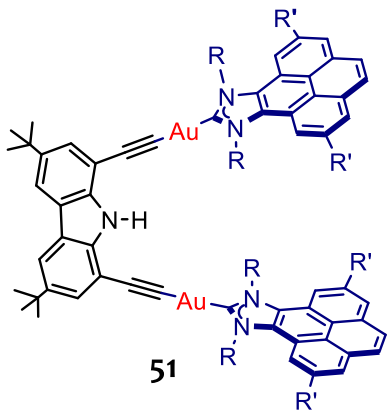

51

Scheme 22. Gold-based meetallotweezers developed in the QOMCAT-UJI group. 
These metallotweezers were used for the for the recognition of 'naked' metal cations $(49)^{[252]}$ and polycyclic aromatic hydrocarbons (PAHs) $(\mathbf{5 1}) .{ }^{[251]}$ The recognition properties of this type of metallotweezers are highly dependent on the nature of the rigid connector, and of the ancillary ligands that constitute the arms of the tweezer (Scheme 19). For 'U-shaped' tweezers combining a rigid polyaromatic connector with polyaromatic functionalities at the arms of the tweezer (49), it was observed that the recognition abilities are highly influenced by the tendency of the tweezer to self-aggregate forming duplex complexes. This self-aggregation is avoided either when the connector displays a V-shaped structure (51) or when the conjugation is disrupted, so that the tether cannot participate in the $\pi-\pi$-stacking event (50). In the case of the metallotweezer $\mathbf{4 9}$ the presence of the pyrene fragment and the $\mathrm{N}-\mathrm{H}$ bond in the carbazole linker enable the receptor to show significant enhanced binding abilities toward PAHs functionalized with $\mathrm{H}$-bonding groups, through combined $\pi-\pi$ stacking and lateral H-bonding. ${ }^{[251]}$ 


\section{References}

[1] J. M. Lehn, Angew. Chem. Int. Ed. 1988, 27, 89-112.

[2] J. M. Lehn, Angew. Chem. Int. Ed. 1990, 29, 1304-1319.

[3] M. C. T. Fyfe, J. F. Stoddart, Acc. Chem. Res. 1997, 30, 393-401.

[4] J.-M. Lehn, Science 2002, 295, 2400-2403.

[5] G. V. Oshovsky, D. N. Reinhoudt, W. Verboom, Angew. Chem. Int. Ed. 2007, 46, 2366-2393.

[6] R. Chakrabarty, P. S. Mukherjee, P. J. Stang, Chem. Rev. 2011, 111, 6810-6918.

[7] C. J. Pedersen, Angew. Chem. Int. Ed. 1988, 27, 1021-1027.

[8] D. J. Cram, Angew. Chem. Int. Ed. 1988, 27, 1009-1020.

[9] A. Priimagi, G. Cavallo, P. Metrangolo, G. Resnati, Acc. Chem. Res. 2013, 46, 2686-2695.

[10] S. Kubik, Chem. Soc. Rev. 2010, 39, 3648-3663.

[11] K. E. Riley, P. Hobza, Acc. Chem. Res. 2013, 46, 927-936.

[12] C. Lescop, Acc. Chem. Res. 2017, 50, 885-894.

[13] S. Dong, B. Zheng, F. Wang, F. Huang, Acc. Chem. Res. 2014, 47, 1982-1994.

[14] Z. Chen, A. Lohr, C. R. Saha-Moeller, F. Wuerthner, Chem. Soc. Rev. 2009, 38, 564-584.

[15] M. Fujita, M. Tominaga, A. Hori, B. Therrien, Acc. Chem. Res. 2005, 38, 369-378.

[16] G. H. Clever, P. Punt, Acc. Chem. Res. 2017, 50, 2233-2243.

[17] L. Chen, Q. Chen, M. Wu, F. Jiang, M. Hong, Acc. Chem. Res. 2015, 48, 201-210.

[18] M. Yanney, F. R. Fronczek, A. Sygula, Angew. Chem. Int. Ed. 2015, 54, 11153-11156.

[19] J. R. Nitschke, Acc. Chem. Res. 2007, 40, 103-112.

[20] E. C. Constable, Chemistry \& Industry 1994, 56-59.

[21] M. M. J. Smulders, I. A. Riddell, C. Browne, J. R. Nitschke, Chem. Soc. Rev. 2013, 42, 1728-1754. 
[22] E. C. Constable, Coord. Chem. Rev. 2008, 252, 842-855.

[23] P. J. Steel, Acc. Chem. Res. 2005, 38, 243-250.

[24] F. Wurthner, C. C. You, C. R. Saha-Moller, Chem. Soc. Rev. 2004, 33, 133-146.

[25] W. Wang, Y. X. Wang, H. B. Yang, Chem. Soc. Rev. 2016, 45, 26562693.

[26] T. R. Cook, V. Vajpayee, M. H. Lee, P. J. Stang, K.-W. Chi, Acc. Chem. Res. 2013, 46, 2464-2474.

[27] T. R. Cook, P. J. Stang, Chem. Rev. 2015, 115, 7001-7045.

[28] S. Leininger, B. Olenyuk, P. J. Stang, Chem. Rev. 2000, 100, 853907.

[29] P. J. Stang, B. Olenyuk, Acc. Chem. Res. 1997, 30, 502-518.

[30] B. H. Northrop, Y. R. Zheng, K. W. Chi, P. J. Stang, Acc. Chem. Res. 2009, 42, 1554-1563.

[31] S. R. Seidel, P. J. Stang, Acc. Chem. Res. 2002, 35, 972-983.

[32] X.-L. Ni, X. Xiao, H. Cong, Q.-J. Zhu, S.-F. Xue, Z. Tao, Acc. Chem. Res. 2014, 47, 1386-1395.

[33] D. W. Zhang, T. K. Ronson, J. R. Nitschke, Acc. Chem. Res. 2018, 51, 2423-2436.

[34] T. R. Cook, Y.-R. Zheng, P. J. Stang, Chem. Rev. 2013, 113, 734777.

[35] A. Casini, B. Woods, M. Wenzel, Inorg. Chem. 2017, 56, 1471514729.

[36] N. C. Gianneschi, M. S. Masar, C. A. Mirkin, Acc. Chem. Res. 2005, $38,825-837$.

[37] D. L. Caulder, K. N. Raymond, Acc. Chem. Res. 1999, 32, 975-982.

[38] A. M. Castilla, W. J. Ramsay, J. R. Nitschke, Acc. Chem. Res. 2014, 47, 2063-2073.

[39] A. J. McConnell, C. S. Wood, P. P. Neelakandan, J. R. Nitschke, Chem. Rev. 2015, 115, 7729-7793.

[40] M. Fujita, K. Ogura, Coord. Chem. Rev. 1996, 148, 249-264.

[41] M. Fujita, Chem. Soc. Rev. 1998, 27, 417-425. 
[42] M. Han, D. M. Engelhard, G. H. Clever, Chem. Soc. Rev. 2014, 43, 1848-1860.

[43] J. C. Barnes, M. Juricek, N. L. Strutt, M. Frasconi, S. Sampath, M. A. Giesener, P. L. McGrier, C. J. Bruns, C. L. Stern, A. A. Sarjeant, J. F. Stoddart, J. Am. Chem. Soc. 2013, 135, 183-192.

[44] T. K. Ronson, W. Meng, J. R. Nitschke, J. Am. Chem. Soc. 2017, 139, 9698-9707.

[45] P. L. Zhang, Chem 2017, 3, 15-16.

[46] M. Otte, ACS Catalysis 2016, 6, 6491-6510.

[47] M. Yoshizawa, J. K. Klosterman, M. Fujita, Angew. Chem. Int. Ed. 2009, 48, 3418-3438.

[48] K. Ariga, H. Ito, J. P. Hill, H. Tsukube, Chem. Soc. Rev. 2012, 41, 5800-5835.

[49] B. Chen, S. Xiang, G. Qian, Acc. Chem. Res. 2010, 43, 1115-1124.

[50] A. Galan, P. Ballester, Chem. Soc. Rev. 2016, 45, 1720-1737.

[51] A. Schmidt, V. Molano, M. Hollering, A. Poethig, A. Casini, F. E. Kuehn, Chem. Eur. J. 2016, 22, 2253-2256.

[52] Y.-R. Zheng, K. Suntharalingam, T. C. Johnstone, S. J. Lippard, Chem. Sci. 2015, 6, 1189-1193.

[53] B. Therrien, in Chemistry of Nanocontainers, (Eds.: M. Albrecht, F. E. Hahn), 2012, 319, 35-55.

[54] C. J. Brown, F. D. Toste, R. G. Bergman, K. N. Raymond, Chem. Rev. 2015, 115, 3012-3035.

[55] S. H. A. M. Leenders, R. Gramage-Doria, B. de Bruin, J. N. H. Reek, Chem. Soc. Rev. 2015, 44, 433-448.

[56] P. Dydio, J. N. H. Reek, Chem. Sci. 2014, 5, 2135-2145.

[57] I. Sinha, P. S. Mukherjee, Inorg. Chem. 2018, 57, 4205-4221

[58] Z. J. Li, Y. F. Han, Z. C. Gao, F. Wang, ACS Catalysis 2017, 7, 4676-4681.

[59] J. R. Nitschke, J. M. Lehn, Proc. Natl. Acad. Sci. U. S. A. 2003, 100, 11970-11974.

[60] G. R. Whittell, I. Manners, Adv. Mater. 2007, 19, 3439-3468. 
[61] S. J. Dalgarno, N. P. Power, J. L. Atwood, Coord. Chem. Rev. 2008, 252, 825-841.

[62] E. C. Constable, Chem. Soc. Rev. 2013, 42, 1637-1651.

[63] P. Ballester, M. Fujita, J. Rebek, Jr., Chem. Soc. Rev. 2015, 44, 392393.

[64] B. H. Northrop, Y.-R. Zheng, K.-W. Chi, P. J. Stang, Acc. Chem. Res. 2009, 42, 1554-1563.

[65] S. Zarra, D. M. Wood, D. A. Roberts, J. R. Nitschke, Chem. Soc. Rev. 2015, 44, 419-432.

[66] E. J. Dale, N. A. Vermeulen, M. Juricek, J. C. Barnes, R. M. Young, M. R. Wasielewski, J. F. Stoddart, Acc. Chem. Res. 2016, 49, 262273.

[67] T. Friscic, Chem. Soc. Rev. 2012, 41, 3493-3510.

[68] P. M. Stricklen, E. J. Volcko, J. G. Verkade, J. Am. Chem. Soc. 1983, 105, 2494-2495.

[69] M. Fujita, J. Yazaki, K. Ogura, J. Am. Chem. Soc. 1990, 112, 56455647.

[70] P. J. Stang, D. H. Cao, J. Am. Chem. Soc. 1994, 116, 4981-4982.

[71] S.-S. Li, B. H. Northrop, Q.-H. Yuan, L.-J. Wan, P. J. Stang, Acc. Chem. Res. 2009, 42, 249-259.

[72] B. H. Northrop, H.-B. Yang, P. J. Stang, Chem. Commun. 2008, 5896-5908.

[73] M. D. Pluth, K. N. Raymond, Chem. Soc. Rev. 2007, 36, 161-171.

[74] M. D. Pluth, R. G. Bergman, K. N. Raymond, Science 2007, 316, 8588.

[75] C. G. Oliveri, P. A. Ulmann, M. J. Wiester, C. A. Mirkin, Acc. Chem. Res. 2008, 41, 1618-1629.

[76] F. J. Rizzuto, L. K. S. von Krbek, J. R. Nitschke, Nat. Rev. Chem. 2019, 3, 204-222.

[77] S. Mukherjee, P. S. Mukherjee, Chem. Commun. 2014, 50, 22392248.

[78] R. V. Slone, K. D. Benkstein, S. Belanger, J. T. Hupp, I. A. Guzei, A. L. Rheingold, Coord. Chem. Rev. 1998, 171, 221-243. 
[79] O. S. Wenger, L. M. Henling, M. W. Day, J. R. Winkler, H. B. Gray, Inorg. Chem. 2004, 43, 2043-2048.

[80] F. A. Cotton, C. Lin, C. A. Murillo, Acc. Chem. Res. 2001, 34, 759771.

[81] S. S. Sun, A. J. Lees, Coord. Chem. Rev. 2002, 230, 171-192.

[82] H.-J. Schneider, A. K. Yatsimirsky, Chem. Soc. Rev. 2008, 37, 263277.

[83] M. Raynal, P. Ballester, A. Vidal-Ferran, P. W. N. M. van Leeuwen, Chem. Soc. Rev. 2014, 43, 1660-1733.

[84] C. Deraedt, D. Astruc, Coord. Chem. Rev. 2016, 324, 106-122.

[85] Y.-F. Han, G.-X. Jin, Acc. Chem. Res. 2014, 47, 3571-3579.

[86] A. K. Singh, D. S. Pandey, Q. Xu, P. Braunstein, Coord. Chem. Rev. 2014, 270, 31-56.

[87] Y.-F. Han, W.-G. Jia, W.-B. Yu, G.-X. Jin, Chem. Soc. Rev. 2009, 38, 3419-3434.

[88] Y. Lu, H.-N. Zhang, G.-X. Jin, Acc. Chem. Res. 2018, 51, 21482158.

[89] Y.-F. Han, G.-X. Jin, Chem. Soc. Rev. 2014, 43, 2799-2823.

[90] B. Therrien, Eur. J. Inorg. Chem. 2009, 2445-2453.

[91] J. Mattsson, P. Govindaswamy, J. Furrer, Y. Sei, K. Yamaguchi, G. Suess-Fink, B. Therrien, Organometallics 2008, 27, 4346-4356.

[92] B. Therrien, G. Suess-Fink, P. Govindaswamy, A. K. Renfrew, P. J. Dyson, Angew. Chem. Int. Ed. 2008, 47, 3773-3776.

[93] N. P. E. Barry, B. Therrien, Eur. J. Inorg. Chem. 2009, 4695-4700.

[94] A. Garci, A. A. Dobrov, T. Riedel, E. Orhan, P. J. Dyson, V. B. Arion, B. Therrien, Organometallics 2014, 33, 3813-3822.

[95] P. Govindaswamy, J. Furrer, G. Suess-Fink, B. Therrien, Z. Anorg. Allg. Chem. 2008, 634, 1349-1352.

[96] S. D. Starnes, D. M. Rudkevich, J. Rebek, J. Am. Chem. Soc. 2001, 123, 4659-4669.

[97] C. R. Bondy, S. J. Loeb, Coord. Chem. Rev. 2003, 240, 77-99.

[98] Y. B. Wang, Z. Y. Lin, J. Am. Chem. Soc. 2003, 125, 6072-6073. 
[99] Y. Shoji, K. Tashiro, T. Aida, J. Am. Chem. Soc. 2010, 132, 59285929.

[100] M. Otte, P. F. Kuijpers, O. Troeppner, I. Ivanovic-Burmazovic, J. N. H. Reek, B. de Bruin, Chem. Eur. J. 2013, 19, 10170-10178.

[101] Y. Shi, K. Cai, H. Xiao, Z. Liu, J. Zhou, D. Shen, Y. Qiu, Q.-H. Guo, C. Stern, M. R. Wasielewski, F. Diederich, W. A. Goddard, J. F. Stoddart, J. Am. Chem. Soc. 2018, 140, 13835-13842.

[102] E. G. Percastegui, J. Mosquera, J. R. Nitschke, Angew. Chem. Int. Ed. 2017, 56, 9136-9140.

[103] W. Brenner, T. K. Ronson, J. R. Nitschke, J. Am. Chem. Soc. 2017, 139, 75-78.

[104] F. J. Rizzuto, J. R. Nitschke, J. Am. Chem. Soc. 2020, 17, 7749-7753

[105] C. Garcia-Simon, M. Garcia-Borras, L. Gomez, T. Parella, S. Osuna, J. Juanhuix, I. Imaz, D. Maspoch, M. Costas, X. Ribas, Nat. Commun. 2014, 5, 5557-5566.

[106] C. Garcia-Simon, M. Costas, X. Ribas, Chem. Soc. Rev. 2016, 45, 4062.

[107] C. Fuertes-Espinosa, C. Garcia-Simon, M. Pujals, M. Garcia-Borras, L. Gomez, T. Parella, J. Juanhuix, I. Imaz, D. Maspoch, M. Costas, X. Ribas, Chem 2020, 6, 169-186.

[108] Z. X. Wu, K. Zhou, A. V. Ivanov, M. Yusobov, F. Verpoort, Coord. Chem. Rev. 2017, 353, 180-200.

[109] M. Fujita, D. Oguro, M. Miyazawa, H. Oka, K. Yamaguchi, K. Ogura, Nature 1995, 378, 469-471.

[110] T. Kusukawa, M. Fujita, J. Am. Chem. Soc. 2002, 124, 13576-13582.

[111] K. Yamashita, M. Kawano, M. Fujita, Chem. Commun. 2007, 41024103.

[112] J. Meeuwissen, J. N. H. Reek, Nat. Chem. 2010, 2, 615-621.

[113] T. S. Koblenz, J. Wassenaar, J. N. H. Reek, Chem. Soc. Rev. 2008, 37, 247-262.

[114] M. J. Wiester, P. A. Ulmann, C. A. Mirkin, Angew. Chem. Int. Ed. 2011, 50, 114-137.

[115] S. Horiuchi, T. Murase, M. Fujita, J. Am. Chem. Soc. 2011, 133, 12445-12447. 
[116] M. Kawano, Y. Kobayashi, T. Ozeki, M. Fujita, J. Am. Chem. Soc. 2006, 128, 6558-6559.

[117] S. Fujii, T. Tada, Y. Komoto, T. Osuga, T. Murase, M. Fujita, M. Kiguchi, J. Am. Chem. Soc. 2015, 137, 5939-5947.

[118] J. K. Klosterman, Y. Yamauchi, M. Fujita, Chem. Soc. Rev. 2009, 38, 1714-1725.

[119] V. Maurizot, M. Yoshizawa, M. Kawano, M. Fujita, Dalton Trans. 2006, 2750-2756.

[120] M. Yoshizawa, J. Nakagawa, K. Kurnazawa, M. Nagao, M. Kawano, T. Ozeki, M. Fujita, Angew. Chem. Int. Ed. 2005, 44, 1810-1813.

[121] L. J. Chen, H. B. Yang, Acc. Chem. Res. 2018, 51, 2699-2710.

[122] S. Borsley, J. A. Cooper, P. J. Lusby, S. L. Cockroft, Chem. Eur. J. 2018, 24, 4542-4546.

[123] H. Takezawa, T. Murase, G. Resnati, P. Metrangolo, M. Fujita, J. Am. Chem. Soc. 2014, 136, 1786-1788.

[124] B. Therrien, Chemistry of Nanocontainers 2012, 319, 35-55.

[125] O. Zava, J. Mattsson, B. Therrien, P. J. Dyson, Chem. Eur. J. 2010, $16,1428-1431$.

[126] J. E. M. Lewis, E. L. Gavey, S. A. Cameron, J. D. Crowley, Chem. Sci. 2012, 3, 778-784.

[127] H. J. Schneider, Angew. Chem. Int. Ed. 1991, 30, 1417-1436.

[128] C. A. Schalley, Mass Spectrom. Rev. 2001, 20, 253-309.

[129] J. J. Cai, J. L. Sessler, Chem. Soc. Rev. 2014, 43, 6198-6213.

[130] H. T. Chifotides, K. R. Dunbar, Acc. Chem. Res. 2013, 46, 894-906.

[131] P. D. Frischmann, M. J. MacLachlan, Chem. Soc. Rev. 2013, 42, 871890.

[132] N. Kishi, Z. Li, Y. Sei, M. Akita, K. Yoza, J. S. Siegel, M. Yoshizawa, Chem. Eur. J. 2013, 19, 6313-6320.

[133] L. Zhang, Y. Cao, N. S. Colella, Y. Liang, J. L. Bredas, K. N. Houk, A. L. Briseno, Acc. Chem. Res. 2015, 48, 500-509.

[134] L. T. Scott, Chem. Soc. Rev. 2015, 44, 6464-6471.

[135] P. G. Ghasemabadi, T. G. Yao, G. J. Bodwell, Chem. Soc. Rev. 2015, 
44, 6494-6518.

[136] I. J. Keyte, R. M. Harrison, G. Lammel, Chem. Soc. Rev. 2013, 42, 9333-9391.

[137] A. K. Haritash, C. P. Kaushik, J. Hazard. Mater. 2009, 169, 1-15.

[138] C. L. Lemieux, A. B. Lambert, S. Lundstedt, M. Tysklind, P. A. White, Environ. Toxicol. Chem. 2008, 27, 978-990.

[139] K. Srogi, Environ. Chem. Lett. 2007, 5, 169-195.

[140] V. Martinez-Agramunt, S. Ruiz-Botella, E. Peris, Chem. Eur. J. 2017, 23, 6675-6681.

[141] E. J. Dale, N. A. Vermeulen, A. A. Thomas, J. C. Barnes, M. Juricek, A. K. Blackburn, N. L. Strutt, A. A. Sarjeant, C. L. Stern, S. E. Denmark, J. F. Stoddart, J. Am. Chem. Soc. 2014, 136, 10669-10682.

[142] H. H. Duan, Y. W. Li, Q. F. Li, P. P. Wang, X. R. Liu, L. Cheng, Y. Yu, L. P. Cao, Angew. Chem. Int. Ed. 2020, 59, 10101-10110.

[143] M. Juricek, J. C. Barnes, E. J. Dale, W. G. Liu, N. L. Strutt, C. J. Bruns, N. A. Vermeulen, K. C. Ghooray, A. A. Sarjeant, C. L. Stern, Y. Y. Botros, W. A. Goddard, J. F. Stoddart, J. Am. Chem. Soc. 2013, 135, 12736-12746.

[144] L. Zhang, L. Lin, D. Liu, Y. J. Lin, Z. H. Li, G. X. Jin, J. Am. Chem. Soc. 2017, 139, 1653-1660.

[145] A. Mishra, S. C. Kang, K. W. Chi, Eur. J. Inorg. Chem. 2013, 2013, $5222-5232$.

[146] J. D. Crowley, I. M. Steele, B. Bosnich, Eur. J. Inorg. Chem. 2005, 3907-3917.

[147] J. D. Crowley, B. Bosnich, Eur. J. Inorg. Chem. 2005, 2015-2025.

[148] R. Lin, J. H. K. Yip, K. Zhang, L. L. Koh, K. Y. Wong, K. P. Ho, J. Am. Chem. Soc. 2004, 126, 15852-15869.

[149] E. M. Lopez-Vidal, A. Fernandez-Mato, M. D. Garcia, M. PerezLorenzo, C. Peinador, J. M. Quintela, J. Org. Chem. 2014, 79, 12651270.

[150] C. Alvarino, E. Pia, M. D. Garcia, V. Blanco, A. Fernandez, C. Peinador, J. M. Quintela, Chem. Eur. J. 2013, 19, 15329-15335.

[151] C. Peinador, E. Pia, V. Blanco, M. D. Garcia, J. M. Quintela, Org. Lett. 2010, 12, 1380-1383. 
[152] V. Blanco, M. D. Garcia, A. Terenzi, E. Pia, A. Fernandez-Mato, C. Peinador, J. M. Quintela, Chem. Eur. J. 2010, 16, 12373-12380.

[153] R. Govindarajan, R. Nagarajaprakash, B. Manimaran, Inorg. Chem. 2015, 54, 10686-10694.

[154] M. H. Yuan, F. Weisser, B. Sarkar, A. Garci, P. Braunstein, L. Routaboul, B. Therrien, Organometallics 2014, 33, 5043-5045.

[155] M. D. Garcia, C. Alvarino, E. M. Lopez-Vidal, T. Rama, C. Peinador, J. M. Quintela, Inorg. Chim. Acta 2014, 417, 27-37.

[156] K. Omoto, S. Tashiro, M. Shionoya, Chem. Sci. 2019, 10, 7172-7176.

[157] A. Pitto-Barry, N. P. E. Barry, O. Zava, R. Deschenaux, B. Therrien, Chem. Asian J. 2011, 6, 1595-1603.

[158] Y. Yamauchi, M. Yoshizawa, M. Akita, M. Fujita, J. Am. Chem. Soc. 2010, 132, 960-966.

[159] M. Iwane, T. Tada, T. Osuga, T. Murase, M. Fujita, T. Nishino, M. Kiguchi, S. Fujii, Chem. Commun. 2018, 54, 12419-12532.

[160] T. Murase, K. Otsuka, M. Fujita, J. Am. Chem. Soc. 2010, 132, 78647865.

[161] N. Singh, J. H. Jo, Y. H. Song, H. Kim, D. Kim, M. S. Lah, K. W. Chi, Chem. Commun. 2015, 51, 4492-4495.

[162] B. M. Schmidt, T. Osuga, T. Sawada, M. Hoshino, M. Fujita, Angew. Chem. Int. Ed. 2016, 55, 1561-1564.

[163] D. Canevet, E. M. Perez, N. Martin, Angew. Chem. Int. Ed. 2011, 50, 9248-9259.

[164] Y. Liu, H. Wang, P. Liang, H. Y. Zhang, Angew. Chem. Int. Ed. 2004, 43, 2690-2694.

[165] J. L. Atwood, G. A. Koutsantonis, C. L. Raston, Nature 1994, 368, 229-231.

[166] K. Tashiro, T. Aida, J. Y. Zheng, K. Kinbara, K. Saigo, S. Sakamoto, K. Yamaguchi, J. Am. Chem. Soc. 1999, 121, 9477-9478.

[167] X. Li, F. Kang, M. Inagaki, Small 2016, 12, 3206-3223.

[168] A. Sygula, Synlett 2016, 27, 2070-2080.

[169] V. H. Le, M. Yanney, M. McGuire, A. Sygula, E. A. Lewis, J. Phys. Chem. B 2014, 118, 11956-11964. 
[170] C. Muck-Lichtenfeld, S. Grimme, L. Kobryn, A. Sygula, PCCP 2010, 12, 7091-7097.

[171] A. Sygula, F. R. Fronczek, R. Sygula, P. W. Rabideau, M. M. Olmstead, J. Am. Chem. Soc. 2007, 129, 3842-3843.

[172] C. M. Alvarez, L. A. Garcia-Escudero, R. Garcia-Rodriguez, J. M. Martin-Alvarez, D. Miguel, V. M. Rayon, Dalton Trans. 2014, 43, 15693-15696.

[173] M. Yanney, A. Sygula, Tetrahedron Lett. 2013, 54, 2604-2607.

[174] A. Sygula, M. Yanney, W. P. Henry, F. R. Fronczek, A. V. Zabula, M. A. Petrukhina, Crystal Growth \& Design 2014, 14, 2633-2639.

[175] C. M. Alvarez, G. Aullon, H. Barbero, L. A. Garcia-Escudero, C. Martinez-Perez, J. M. Martin-Alvarez, D. Miguel, Org. Lett. 2015, 17, 2578-2581.

[176] C. Mejuto, L. Escobar, G. Guisado-Barrios, P. Ballester, D. Gusev, E. Peris, Chem. Eur. J. 2017, 23, 10644-10651.

[177] A. Ikeda, M. Yoshimura, H. Udzu, C. Fukuhara, S. Shinkai, J. Am. Chem. Soc. 1999, 121, 4296-4297.

[178] A. Ikeda, H. Udzu, M. Yoshimura, S. Shinkai, Tetrahedron 2000, 56, 1825-1832.

[179] L. Pirondini, D. Bonifazi, B. Cantadori, P. Braiuca, M. Campagnolo, R. De Zorzi, S. Geremia, F. Diederich, E. Dalcanale, Tetrahedron 2006, 62, 2008-2015.

[180] C. G. Claessens, T. Torres, Chem. Commun. 2004, 1298-1299.

[181] K. Suzuki, K. Takao, S. Sato, M. Fujita, J. Am. Chem. Soc. 2010, 132, 2544-2545.

[182] N. Kishi, M. Akita, M. Yoshizawa, Angew. Chem. Int. Ed. 2014, 53, 3604-3607.

[183] M. Poyatos, J. A. Mata, E. Peris, Chem. Rev. 2009, 109, 3677-3707.

[184] J. A. Mata, M. Poyatos, E. Peris, Coord. Chem. Rev. 2007, 251, 841859.

[185] F. E. Hahn, C. Radloff, T. Pape, A. Hepp, Organometallics 2008, 27, 6408-6410.

[186] C. Radloff, J. J. Weigand, F. E. Hahn, Dalton Trans. 2009, 93929394. 
[187] C. Radloff, F. E. Hahn, T. Pape, R. Fröhlich, Dalton Trans. 2009, 7215-7222.

[188] F. M. Conrady, R. Fröhlich, C. Schulte to Brinke, T. Pape, F. E. Hahn, J. Am. Chem. Soc. 2011, 133, 11496-11499.

[189] M. Schmidtendorf, T. Pape, F. E. Hahn, Angew. Chem. Int. Ed. 2012, 51, 2195-2198.

[190] M. Viciano, M. Sanau, E. Peris, Organometallics 2007, 26, 60506054.

[191] C. Mejuto, G. Guisado-Barrios, D. Gusev, E. Peris, Chem. Commun. 2015, 51, 13914-13917.

[192] N. Sinha, F. Roelfes, A. Hepp, C. Mejuto, E. Peris, F. E. Hahn, Organometallics 2014, 33, 6898-6904.

[193] F. E. Hahn, C. Radloff, T. Pape, A. Hepp, Chem. Eur. J. 2008, 14, 10900-10904.

[194] C. Radloff, H. Y. Gong, C. Schulte to Brinke, T. Pape, V. M. Lynch, J. L. Sessler, F. E. Hahn, Chem. Eur. J. 2010, 16, 13077-13081.

[195] A. Rit, T. Pape, F. E. Hahn, J. Am. Chem. Soc. 2010, 132, 45724573.

[196] A. Rit, T. Pape, A. Hepp, F. E. Hahn, Organometallics 2011, 30, 334-347.

[197] D. H. Wang, B. G. Zhang, C. He, P. Y. Wu, C. Y. Duan, Chem. Commun. 2010, 46, 4728-4730.

[198] C. Segarra, G. Guisado-Barrios, F. E. Hahn, E. Peris, Organometallics 2014, 33, 5077-5080.

[199] O. Guerret, S. Sole, H. Gornitzka, M. Teichert, G. Trinquier, G. Bertrand, J. Am. Chem. Soc. 1997, 119, 6668-6669.

[200] B. Karimi, P. F. Akhavan, Chem. Commun. 2009, 3750-3752.

[201] B. Karimi, P. F. Akhavan, Inorg. Chem. 2011, 50, 6063-6072.

[202] B. Karimi, P. F. Akhavan, Chem. Commun. 2011, 47, 7686-7688.

[203] A. J. Boydston, C. W. Bielawski, Dalton Trans. 2006, 4073-4077.

[204] L. Mercs, A. Neels, M. Albrecht, Dalton Trans. 2008, 5570-5576.

[205] L. Mercs, A. Neels, H. Stoeckli-Evans, M. Albrecht, Dalton Trans. 2009, 7168-7178. 
[206] C. Zhang, J. J. Wang, Y. Liu, H. Ma, X. L. Yang, H. B. Xu, Chem. Eur. J. 2013, 19, 5004-5008.

[207] J. Choi, H. Y. Yang, H. J. Kim, S. U. Son, Angew. Chem. Int. Ed. 2010, 49, 7718-7722.

[208] S. Gonell, M. Poyatos, E. Peris, Chem. Eur. J. 2014, 20, 5746-5751.

[209] A. Pothig, A. Casini, Theranostics 2019, 9, 3150-3169.

[210] D. Fink, N. Orth, V. Ebel, F. S. Gogesch, A. Staiger, M. Linseis, I. Ivanović-Burmazović, R. F. Winter, Organometallics 2020.

[211] D. Fink, N. Orth, M. Linseis, I. Ivanović-Burmazović, R. F. Winter, Chem. Commun. 2020, 56, 1062-1065.

[212] P. J. Stang, N. E. Persky, J. Manna, J. Am. Chem. Soc. 1997, 119, 4777-4778.

[213] H. Jiang, W. Lin, J. Am. Chem. Soc. 2003, 125, 8084-8085.

[214] J. C. Garrison, M. J. Panzner, P. D. Custer, D. V. Reddy, P. L. Rinaldi, C. A. Tessier, W. J. Youngs, Chem. Commun. 2006, 46444646.

[215] B. Olenyuk, J. A. Whiteford, A. Fechtenkötter, P. J. Stang, Nature 1999, 398, 796-799.

[216] L. Zhao, K. Ghosh, Y.-R. Zheng, P. J. Stang, J. Org. Chem. 2009, 74, 8516-8521.

[217] S. Ghosh, R. Chakrabarty, P. S. Mukherjee, Inorg. Chem. 2009, 48, 549-556.

[218] F. E. Hahn, V. Langenhahn, T. Lugger, T. Pape, D. Le Van, Angew. Chem. Int. Ed. 2005, 44, 3759-3763.

[219] M. M. Gan, J. Q. Liu, L. Zhan, Y. Y. Wang, F. E. Hahn, Y. F. Han, Chem. Rev. 2018, 118, 9587-9641.

[220] N. Sinha, F. E. Hahn, Acc. Chem. Res. 2017, 50, 2167-2184.

[221] J. W. Wang, H. B. Song, Q. S. Li, F. B. Xu, Z. Z. Zhang, Inorg. Chim. Acta 2005, 358, 3653-3658.

[222] P. L. Chiu, C. Y. Chen, J. Y. Zeng, C. Y. Lu, H. M. Lee, J. Organomet. Chem. 2005, 690, 1682-1687.

[223] J. W. Wang, Q. S. Li, F. B. Xu, H. B. Song, Z. Z. Zhang, Eur. J. Org. Chem. 2006, 1310-1316. 
[224] M. Fujita, G. Ogura, Bull. Chem. Soc. Jpn 1996, 69, 1471-1482.

[225] Y.-W. Zhang, R. Das, Y. Li, Y.-Y. Wang, Y.-F. Han, Chem. Eur. J. 2019, 25, 5472-5479.

[226] E. Mas-Marza, J. A. Mata, E. Peris, Angew. Chem. Int. Ed. 2007, 46, 3729-3731.

[227] S. Gonell, M. Poyatos, E. Peris, Chem. Eur. J. 2014, 20, 9716-9724.

[228] A. Prades, E. Peris, M. Alcarazo, Organometallics 2012, 31, 46234626.

[229] H. Valdes, M. Poyatos, E. Peris, Organometallics 2015, 34, 17251729.

[230] A. J. Boydston, K. A. Williams, C. W. Bielawski, J. Am. Chem. Soc. 2005, 127, 12496-12497.

[231] S. Gonell, M. Poyatos, E. Peris, Angew. Chem. Int. Ed. 2013, 52, 7009-7013.

[232] S. Gonell, R. G. Alabau, M. Poyatos, E. Peris, Chem. Commun. 2013, 49, 7126-7128.

[233] C. Segarra, J. Linke, E. Mas-Marza, D. Kuck, E. Peris, Chem. Commun. 2013, 49, 10572-10574.

[234] C. Schulte to Brinke, T. Pape, F. E. Hahn, Dalton Trans. 2013, 42, $7330-7337$.

[235] A. Sinha, F. Roelfes, A. Hepp, E. F. Hahn, Chem. Eur. J. 2017, 23, 5939-5942.

[236] M. Schmidtendorf, T. Pape, F. E. Hahn, Dalton Trans. 2013, 42, 16128-16141.

[237] M. Schmidtendorf, C. S. to Brinke, F. E. Hahn, J. Organomet. Chem. 2014, 751, 620-627.

[238] P. J. Altmann, A. Pothig, J. Am. Chem. Soc. 2016, 138, 13171-13174.

[239] P. J. Altmann, A. Pöthig, Angew. Chem. Int. Ed. 2017, 56, 15733 15736.

[240] S. Ibáñez, E. Peris, Angew. Chem. Int. Ed. 2020, 59, 6860-6865

[241] S. Ibañez, E. Peris, Angew. Chem. Int. Ed. 2019, 58, 6693-6697.

[242] A. Gutiérrez-Blanco, S. Ibáñez, F. E. Hahn, M. Poyatos, E. Peris, Organometallics 2019, 38, 4565-4569. 
[243] V. Martinez-Agramunt, D. Gusev, E. Peris, Chem. Eur. J. 2018, 24, 14802-14807.

[244] V. Martínez-Agramunt, E. Peris, Chem. Commun. 2019, 55, 1497214975.

[245] V. Martinez-Agramunt, E. Peris, Inorg. Chem. 2019, 58, 1183611842.

[246] V. Martinez-Agramunt, T. Eder, H. Darmandeh, G. Guisado-Barrios, E. Peris, Angew. Chem. Int. Ed. 2019, 58, 5682-5686.

[247] M. Hardouin-Lerouge, P. Hudhomme, M. Salle, Chem. Soc. Rev. 2011, 40, 30-43.

[248] F. G. Klarner, T. Schrader, Acc. Chem. Res. 2013, 46, 967-978.

[249] J. Leblond, A. Petitjean, Chemphyschem 2011, 12, 1043-1051.

[250] M. Harmata, Acc. Chem. Res. 2004, 37, 862-873.

[251] C. Biz, S. Ibañez, M. Poyatos, D. Gusev, E. Peris, Chem. Eur. J. 2017, 23, 14439-14444.

[252] S. Ibañez, M. Poyatos, E. Peris, Angew. Chem. Int. Ed. 2017, 56, 9786-9790.

[253] S. Ibañez, E. Peris, Chem. Eur. J. 2018, 24, 8424-8431.

[254] S. Ibañez, M. Poyatos, E. Peris, Angew. Chem. Int. Ed. 2018, 57, 16816-16820.

[255] S. Ibañez, E. Peris, Chem. Eur. J. 2019, 25, 8254-8258. 


\section{OBJECTIVES}

The main target of this Doctoral Thesis is the development of Supramolecular Organometallic Complexes (SOCs) based on a pyreneconnected di-N-heterocyclic carbene, for their use as hosts for a series of organic molecules. This general objective can be divided into the following more specific objectives:

- Developing effective synthetic protocols for the preparation of nickel- and palladium conjoined 2- and 3-dimensional architectures bearing a pyrene-di-N-heterocyclic carbene ligand.

- Studying the host-guest chemistry properties of these supramolecular assemblies as hosts for polycyclic aromatic hydrocarbons.

- Studying the host-guest chemistry properties of these supramolecular organometallic complexes as hosts for 3-D all-carbon molecules, such as fullerenes.

- Studying the ability of the fullerene-containing host-guest complexes as singlet oxygen photosensitizers, use these assemblies as photocatalysts for the epoxidation and endoperoxidation of cyclic and acyclic alkenes

- Studying the ability of the organometallic supramolecular assemblies obtained, as hosts for multiple guests, and determine their ability to construct systems with discrete multiple stacks. 


\section{Objectives}

Justification: All these objectives are built on the basis of the abilities of pyrene-containing ligands to magnify $\pi-\pi$-stacking interactions, and therefore the supramolecular assemblies constructed with this moiety are expected to show enhanced affinities for $\pi$-extended polyconjugated guests. Given the current concern about the high toxicity of polycyclic aromatic hydrocarbons (PAHs), we consider that these substrates constitute excellent molecules for host-guest studies, especially in view to find effective/selective PAHscavengers. In addition, fullerenes are all-carbon 3-dimensional molecules which are difficult to separate. Building supramolecular receptors capable to selectively encapsulate fullerenes is one of the current challenges of supramolecular chemistry. Finally, given the excellent spin-converting properties of fullerenes, it is expected that fullerene-containing assemblies constitute excellent candidates for the generation of singlet oxygen via visible light irradiation. 


\section{OBJETIVOS}

El objetivo principal de la presente Tesis Doctoral es el desarrollo de Complejos Organometálicos Supramoleculares (SOCs) basados en un ligando del tipo biscarbeno N-Heterocíclico conectado por un fragmento pireno. Este objetivo principal puede dividirse en los siguientes objetivos más específicos:

- Desarrollo de protocolos sintéticos eficaces en la preparación de arquitecturas bidimensionales y tridimensionales de níquel y paladio basadas en un ligando de pireno bis-carbeno N-Heterocíclico.

- Estudio de las propiedades host-guest de estos ensamblajes supramoleculares como receptores de hidrocarburos policíclicos aromáticos

- Estudio de las propiedades host-guest de estos complejos organometálicos supramoleculares como receptores de moléculas tridimensionales basadas únicamente en carbono, tales como fulerenos.

- Estudio de la actividad fotocatalítica de los complejos host-guest con fulereno encapsulado en reacciones de epoxidación y endoperoxidación de alquenos cíclicos y acíclicos, en las que el complejo host-guest se comporta como fotosensibilidazor en la generación de oxígeno singlete.

- Estudio de la capacidad del complejo organometálico supramolecular para actuar como receptor de múltiples moléculas y determinar su capacidad de formar sistemas con apilamientos discretos de múltiples moléculas. 


\section{Objetivos}

Justificación: Todos estos objetivos, están diseñados en torno a maximizar las interacciones del tipo apilamiento- $\pi$ entre ligandos que contengan pireno, y moléculas poliaromáticas. Con lo cual, las estructuras supramoleculares construidas estos ligandos, se espera que presenten una elevada afinidad hacia moléculas con sistemas $\pi$-policonjugados. Dada la actual preocupación medioambiental debido a la alta toxicidad de los hidrocarburos policíclicos aromáticos (PAHs), creemos que el estudio host-guest de este tipo de moléculas, constituye una excelente oportunidad en vistas de encontrar un receptor capaz de encapsularlos en su cavidad para así extraerlos de una forma eficaz y selectiva. Además, los fulerenos, son una serie compuestos tridimensionales formados únicamente por carbono, la separación de los cuales constituye una ardua tarea. Por esta razón, la síntesis de receptores supramoleculares capaces de encapsular selectivamente fulerenos es uno de los desafíos actuales de la química supramolecular. Por último, dadas las excelentes propiedades de los fulerenos como conversores de spin, es esperable que los SCC con fulereno encapsulado en su cavidad sean unos excelentes candidatos para la generación de oxígeno singlete. 


\section{SUMMARY}

The field of metallo-supramolecular chemistry is dominated by the use of $\mathrm{O}$ $\mathrm{N}$ - and P-donor Werner-type polydentate ligands. This type of molecular architectures is of high interest due to their wide range of applications, including molecular encapsulation, stabilization of reactive species, supramolecular catalysis and drug delivery, among others. Only recently, organometallic ligands have allowed the preparation of a variety of supramolecular coordination complexes, and the term Supramolecular Organometallic Complexes (SOCs), is gaining space within the field of metallo-supramolecular chemistry. The development of SOCs during the last decade has been boosted by the parallel development of multi-dentate $\mathrm{N}$ heterocyclic carbene (NHC) ligands. Although the number of SOCs has increased in the last few years, their use in host-guest chemistry purposes is still at its earliest infancy. Taking all this into account, this research is built on the basis of the abilities of pyrene-containing ligands to magnify $\pi-\pi$ stacking interactions and therefore the supramolecular assemblies constructed with this moiety are expected to show enhanced affinities for $\pi$ extended poly-conjugated guests. Thus, the main target of this Doctoral Thesis is the development of supramolecular organometallic complexes based on a pyrene-connected di-N-heterocyclic carbene, for their use as hosts for a series of organic molecules.

By using a common pyrene-connected di-N-heterocyclic-carbene ligand, four SOCs were prepared (Scheme 1): two nickel-cornered organometallic metalla-rectangles ( $\mathbf{1}$ and $\mathbf{2}$ ), a nickel-based molecular trigonal prism (3) and a palladium-conjoined molecular square (4). 
The metallorectangles $\mathbf{1}$ and $\mathbf{2}$ contain two pyrene-di-imidazolylidene ligands a two pyrazines (1) or 4,4'-bypyridines (2). The dimensions of the two molecular boxes depend on the N-donor ligand used. For both complexes the side built with the pyrene-di-NHC measures $13 \AA$, while the side bound by the di-N-donor ligand measures $7 \AA$ for $\mathbf{1}$, and $11 \AA$ for $\mathbf{2}$. Both molecular boxes were used for the encapsulation of polycyclic aromatic hydrocarbons (PAH). The binding abilities of the two hosts were clearly dependent on the dimensions of the cavity. The smaller molecule, $\mathbf{1}$, was able to encapsulate only one guest molecule, while $\mathbf{2}$ was able to encapsulate two PAH molecules.
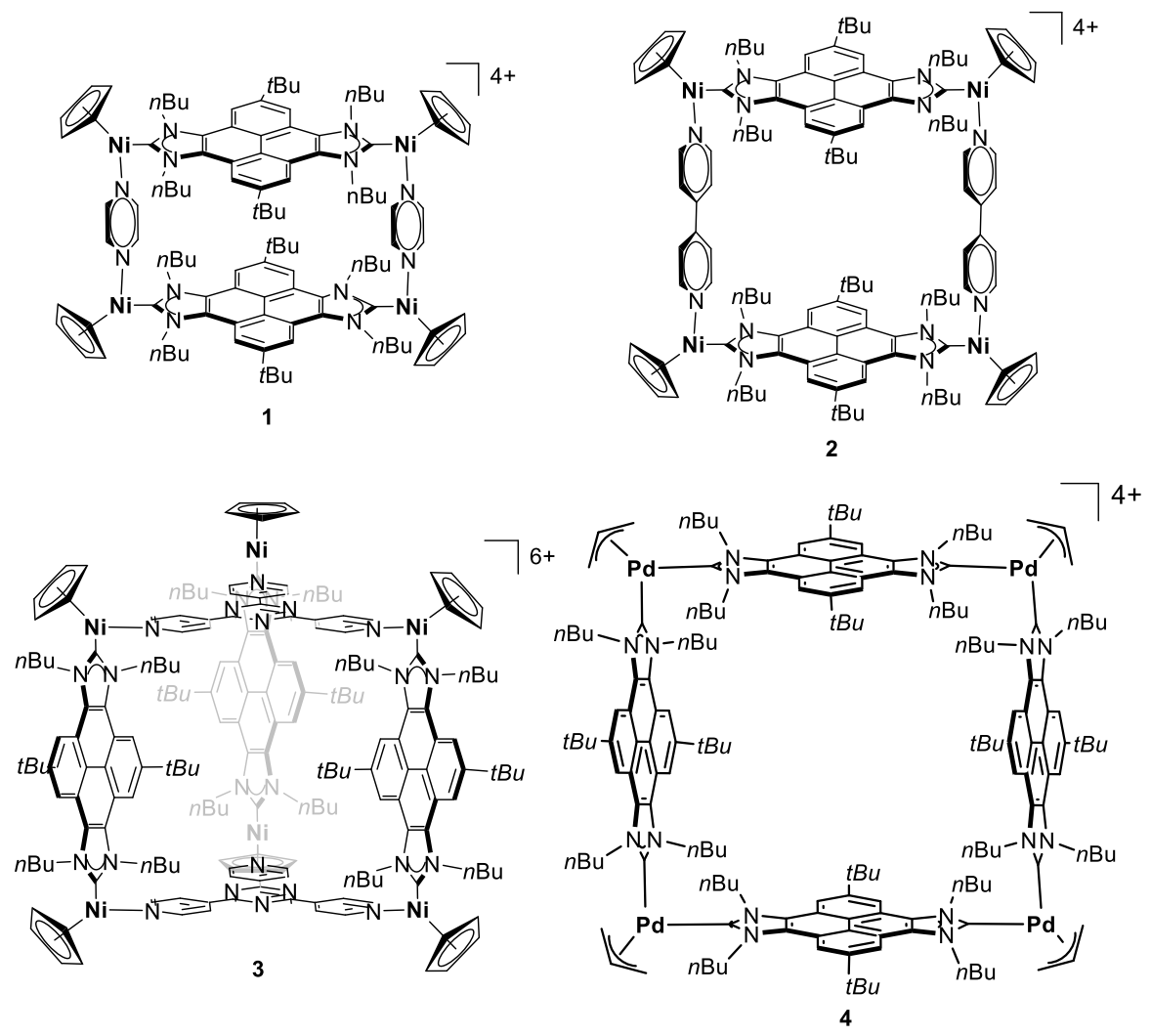

Scheme 1: All four supramolecular organometallic complexes obtained in this research. 
The determination of the association constants by ${ }^{1} \mathrm{H}$ NMR spectroscopy in acetone- $d_{6}$, indicated that the binding strength are in the order perylene < naphthalene < phenanthrene < anthracene < pyrene < triphenylene, with constants ranging from $130-4400 \mathrm{M}^{-1}$ for the case of $\mathbf{1}$. Lower constants were found when 2 were used. The trend in the binding affinities indicates that larger PAHs show a higher binding strength than smaller ones, because larger guests facilitate a more efficient face-to-face overlap. For the case of perylene, the constant is very small, because its size is too large to fit in the cavity. In a parallel experiment we showed that $\mathbf{1}$ is able to fully extract pyrene from a solution of this $\mathrm{PAH}$ in heptane, therefore illustrating that $\mathbf{1}$ can be used as a pyrene-scavenger. After the preparation of 1 and 2 and the study of their host-guest properties, we aimed to obtain a three-dimensional host with a larger cavity, so that we could use it for the encapsulation of three dimensional guests, such as fullerenes. Thus the molecular trigonal prismatic molecule $\mathbf{3}$ was built by combining three pyrene-bisimidazolylidene ligands and two of tris-(4-pyrdil)triazines.The X-ray diffraction structure of the molecule (Figure 1) reveals that the cage possesses an internal cavity with a volume of $1028 \AA^{3}$, thus suitable for the encapsulation of large 3D-molecules, such as fullerenes (Scheme 2). This cage shows highly selective complexation of $\mathrm{C}_{70}$ over $\mathrm{C}_{60}$, showing its potential applications for fullerene separation and purification. The determination of the binding constants of 3 with $\mathrm{C}_{60}$ and $\mathrm{C}_{70}$ was determined by ${ }^{1} \mathrm{H}$ NMR spectroscopy in a mixture of acetone/1,2-dichlorobenzene at different temperatures. This actually allowed us to determine the thermodynamic values associated to the encapsulation, by using the corresponding Van't Hoff plots. The values obtained were $\Delta \mathrm{H}=3.1$ 
$\mathrm{kcal} / \mathrm{mol}$ and $\Delta \mathrm{S}=27 \mathrm{cal} / \mathrm{molK}$ for $\mathrm{C}_{60}$ and $\Delta \mathrm{H}=3.8 \mathrm{kcal} / \mathrm{mol}$ and $\Delta \mathrm{S}=34$ $\mathrm{cal} / \mathrm{molK}$ for $\mathrm{C}_{70}$.

Thus, the complexation is entropically favored by desolvation of the host and the guest. The complexation of $\mathrm{C}_{70}$ shows a greater value of $\Delta \mathrm{S}$ due to the larger number of solvent molecules bound to $\mathrm{C}_{70}$ relative to $\mathrm{C}_{60}$. The endothermicity of the associations is explained by the large solvation enthalpies of the host and guest.

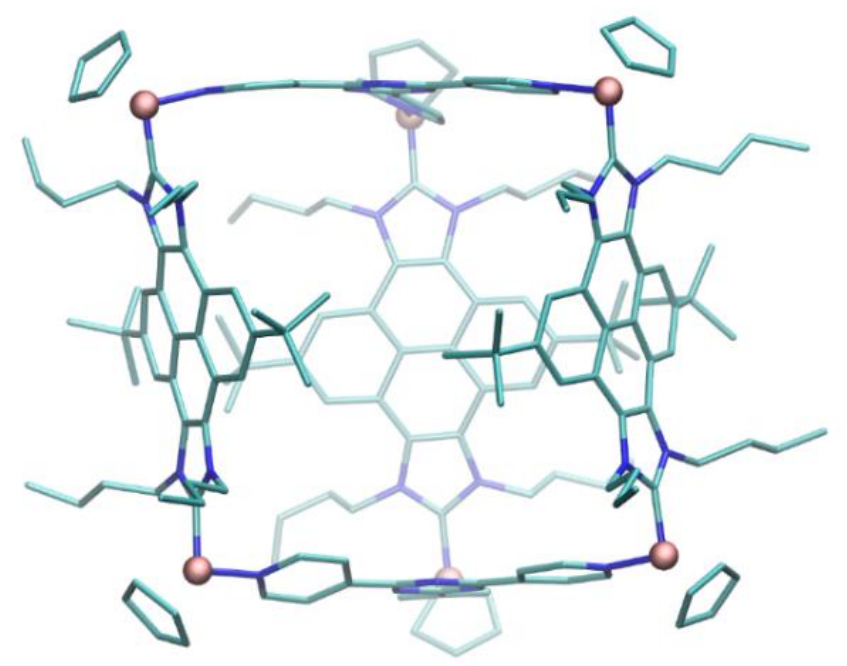

Figure 1: X-ray diffraction structure of $\mathbf{3}$ (hydrogen atoms and counter-anions omitted for clarity).

The palladium-cornered metallosquare 4 was obtained in a one-pot reaction by mixing a pyrene.bis-imidazolium salt and $[\mathrm{Pd}(\text { allyl }) \mathrm{Cl}]_{2}$ in acetonitrile in the presence of $\mathrm{AgBF}_{4}$ and $\mathrm{Cs}_{2} \mathrm{CO}_{3}$. This molecular assembly can be described as a metallo-square, although the flat polyaromatic surface of the four pyrene moieties generates a "three-dimensional", rather than a "twodimensional" macrocyclic cubic box. This metallo-box was used for the 
encapsulation of fullerenes $\mathrm{C}_{60}$ and $\mathrm{C}_{70}$, and the resulting binding affinities were calculated by ${ }^{1} \mathrm{H}$ NMR spectroscopy in 1,2-dichlorobencene at different temperatures. The results obtained showed that the host showed a higher affinity for the larger fullerene $\mathrm{C}_{70}$. The thermodynamic values found for the encapsulation of $\mathrm{C}_{60}$ were $\Delta \mathrm{H}=1.7 \mathrm{kcal} / \mathrm{mol}$ and $\Delta \mathrm{S}=22 \mathrm{cal} / \mathrm{molK}$. For the encapsulation of $\mathrm{C}_{70}$, the values obtained were $\Delta \mathrm{H}=3.9 \mathrm{kcal} / \mathrm{mol}$ and $\Delta \mathrm{S}=$ $34 \mathrm{cal} / \mathrm{molK}$. The small and positive values of the association enthalpies can be explained due to the large solvation enthalpies of the fullerenes in odichlorobenzene.

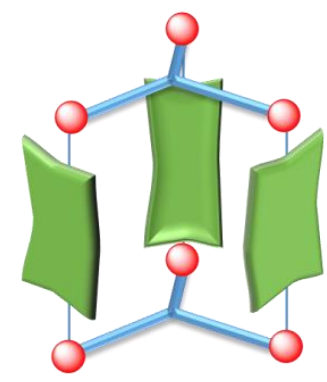

Scheme 2: Schematic representation of the encapsulation of fullerenes inside $\mathbf{3}$ in odichlorobenzene.

The molecular structures of the empty molecule of 4 , and the ones with encapsulated $\mathrm{C}_{60}$ and $\mathrm{C}_{70}$ were obtained by X-ray diffraction studies (Figure 2). These structures show that the metallo-square is size-flexible, and therefore able to adapt its shape to the size of the encapsulated fullerene. This is achieved by compressing or expanding the structure and by bending the pyrene moieties in order to maximize the face-to-face overlap with the convex surface of the fullerenes. An important feature of $\mathrm{C}_{60} @ \mathbf{4}$ and $\mathrm{C}_{70} @ 4$ 
is that both host-guest complexes behaved as singlet oxygen photosensitizers.

By taking advantage of this property, the metallocage with the encapsulated fullerenes is able to oxidize a series of alkenes at room temperature via visible light-induced singlet oxygen generation, using oxygen molecules in air at atmospheric pressure (Scheme 3).
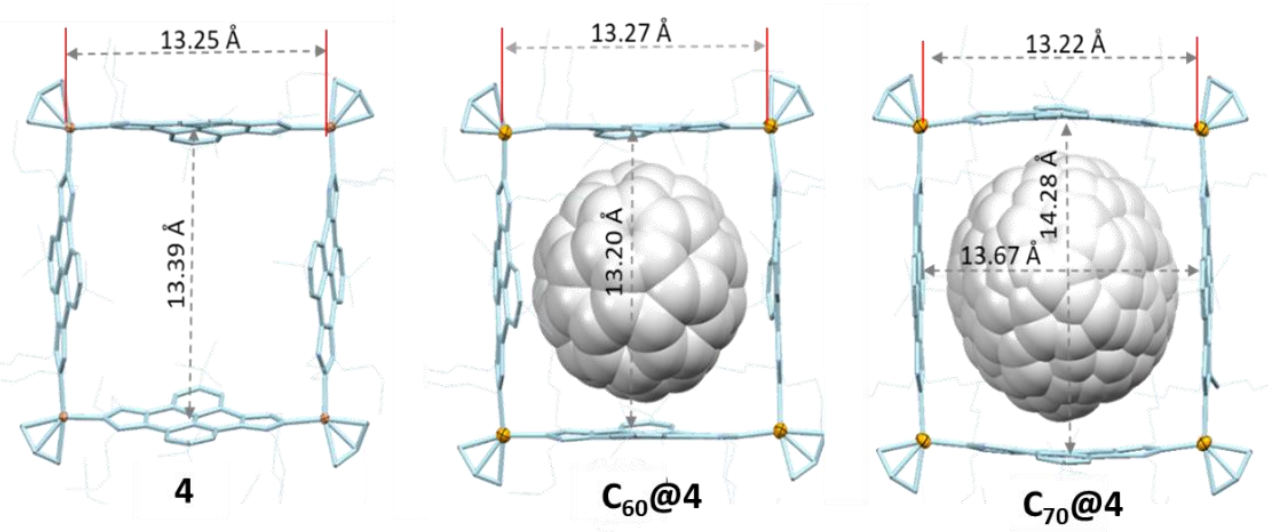

Figure 2. X-ray diffraction structures of 4 (left), $\mathrm{C}_{60} @ 4$ (middle), and $\mathrm{C}_{70} @ 4$ (right), showing some selected dimensions. Hydrogen atoms, counteranions $\left(\mathrm{BF}_{4}^{-}\right)$and solvent molecules omitted for clarity. Two molecules of $\mathrm{C}_{70}(0.5$

By measuring the phosphorescence emission spectra of singlet oxygen generated of the two complexes upon irradiation with visible light, ${ }^{1} \mathrm{O}_{2}$ quantum yields of $\Phi_{\Delta}=0.23$ and 0.41 , were obtained for $\mathrm{C}_{60} @ \mathbf{4}$ and $\mathrm{C}_{70} @ \mathbf{4}$, respectively, and this explains the larger photocatalytic activity shown by $\mathrm{C}_{70} @ 4$ compared to that shown by $\mathrm{C}_{60} @ 4$. These results are important because they suggest that other fullerene-containing supramolecular systems have the potential for being used for similar catalytic reactions. 


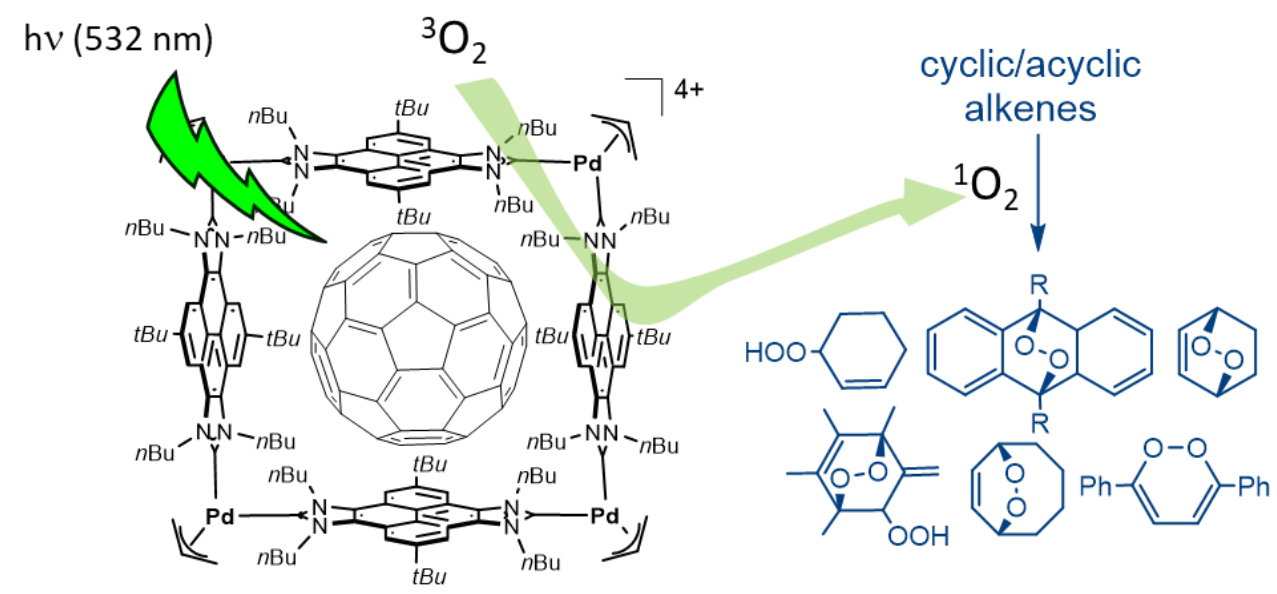

Scheme 3: Fullerene-containing box 4 used as photocatalyst for the peroxidation of cyclic and acyclic alkenes

The palladium cage was found to display a perfect-sized cavity for the encapsulation of three heteroguests (Figure 3). These included two electronrich polycyclic aromatic hydrocarbons (pyrene, triphenylene or coronene), and one molecule of naphthalene tetracarboxydiimide (NTCDI). This enabled the formation of quintuple D-A-D-A-D stacks, in which the two pyrene panels frome the host constitute the bookend donors. Such type of a discrete p-stack is very interesting, because it established a model for the construction of electronic devices at the molecular level. The encapsulating properties of the metallosquare were clearly determined by the presence of the pyrene panels, which endow the metallosquare a three-dimensional shape, thus behaving as an effective antenna for $\pi$-stacking interactions. Clearly, the addition of the heteroguests to the structure of $\mathbf{4}$ is affected by a cooperative effect, in which the presence of the PAH guests has a positive influence in the encapsulation of the molecules of NTCDI. Unlike any other metallosupramolecular systems previously used for the encapsulation of 
multiple heteroguests, our metallosquare 4 is the first one to show a square structure, while all other known examples are based on 'closed' trigonal prismatic architectures.

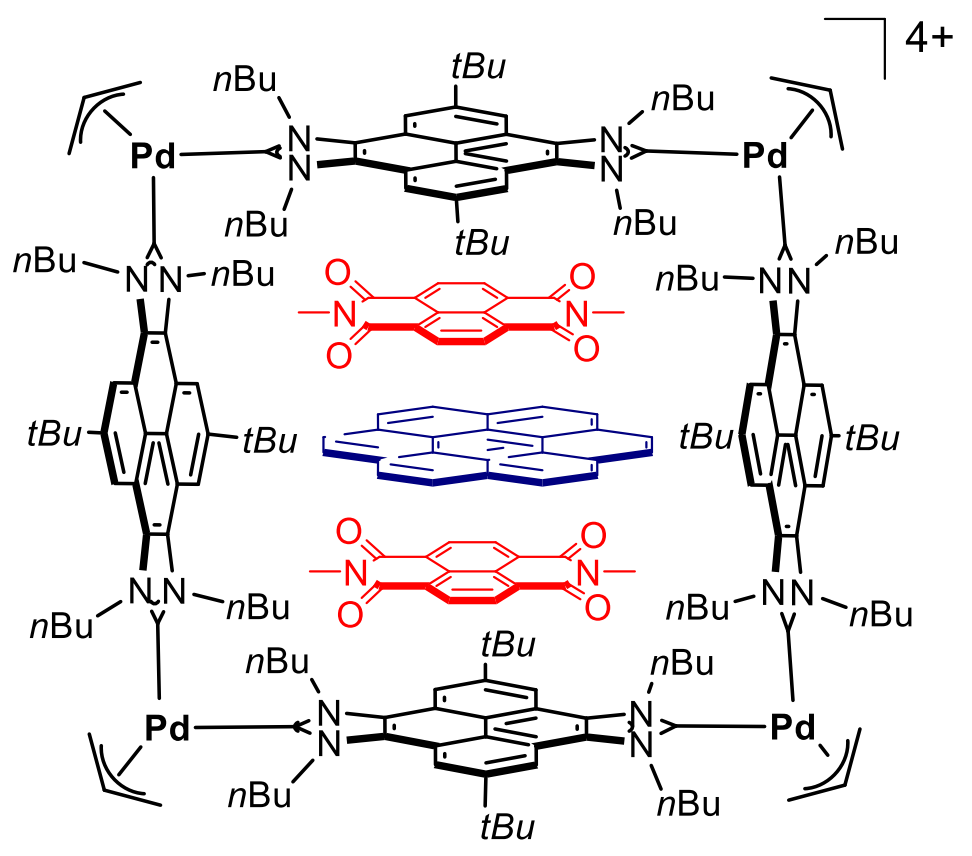

(G1+2G2)@[4]

Figure 3: Host-guest association complex of the tetrametallic palladium-based supramolecular cage $\mathbf{4}$ and three heteroguests molecules. The red molecules are Naphtalene Tetracarboxidiimide (NTCDI) whilst the blue one is a coronene molecule. In this work, apart from coronene we were also able to encapsulate other PAH between the NTCDI tags, such as pyrene or triphenylene.

In summary, we developed a new family of Supramolecular Organometallic Complexes (SOCs) with a great potential as selective receptors for different guests. After the study of the host-guest chemistry of these compounds we develop an efficient strategy for the recognition and encapsulation of high value molecules such as PAH and fulerenes. Our SOCs were used as selective PAH-receptors with a linear correlation of number of $\pi$-electrons 
and binding strength and as effective PAH- scavengers. Our SOCs were also used as selective fulerene receptors adapting the size of their cavity to the shape of the fullerene. The SOCs were also used as efficient photosensitizers in the generation of singlet oxygen from atmospheric air and visible light, being able of oxidase a great variety of alkenes photocatalytically. Finally, the SOCs were able to host a series of planar heteroguests via $\pi$-stacking interactions. 


\section{RESUMEN}

El campo de la química supramolecular con metales de coordinación está dominado por los ligandos polidentados del tipo Wener O- N- y P-dadores. Este tipo de estructuras moleculares tiene un alto interés debido a su gran rango de aplicaciones, entre las que se incluyen la encapsulación molecular, la estabilización de especies reactivas, catálisis supramolecular y liberamiento de fármacos, entre otras. Únicamente en los últimos años se han utilizado ligandos organometálicos en la preparación de Complejos de Coordinación Supramoleculares (SCCs), y es ahora cuando el término Complejos Organometálicos Supramoleculares (SOCs) se está abriendo paso en el campo de la química supramolecular con metales de coordinación. El desarrollo de SOCs durante los últimos años ha estado potenciado por el desarrollo paralelo de ligando multidentandos basados en carbenos $\mathrm{N}$ heterocíclicos (NHCs). Aunque el número de SOCs se ha visto incrementado en los últimos años, su uso en la química host-guest todavía no ha sido explotado. Teniendo todo esto en cuenta, esta investigación está construida sobre las bases de ligandos que contienen un fragmento pireno para maximizar las interacciones de apilamiento- $\pi$, con el fín de que los ensamblajes supramoleculares construídos con este fragmento presenten una alta afinidad por moléculas poliaromáticas. Por consiguiente, el objetivo principal de esta Tesis Doctoral es el desarrollo de complejos organometálicos supramoleculares basados en ligandos carbeno $\mathrm{N}$ Heterocíclicos con fragmentos pireno para su posterior uso como receptores de diferentes moléculas orgánicas de alto interés. 
Así pues, a partir de un ligando biscarbeno N-Heterocíclico conectado por pireno, cuatro SOCs fueron preparados (Esquema 1): dos metalo-rectángulos basados en níquel ( $\mathbf{1}$ y $\mathbf{2}$ ), un prisma trigonal basado en níquel (3) y un cuadrado molecular basado en paladio (4).

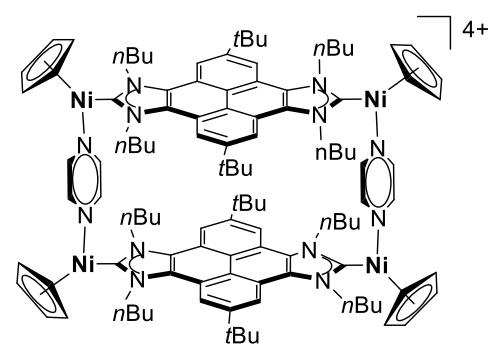

1

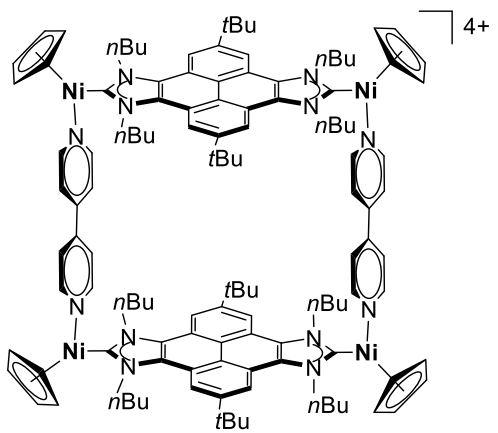

2

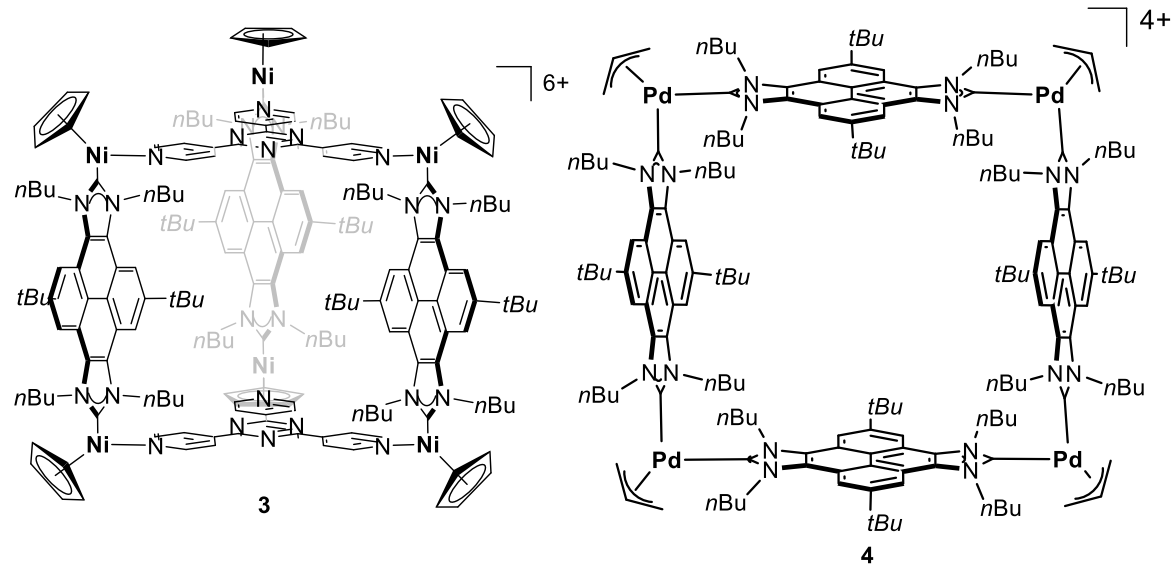

Esquema 1: Los cuatro complejos organometálicos supramoleculares obtenidos en esta investigación.

Los metalo-rectángulos $\mathbf{1}$ y $\mathbf{2}$ contienen dos ligandos pireno bisimidazolilideno y dos pirazinas (1) o 4,4'-bipiridinas (2). Las dimensiones de las dos cajas dependen del ligando $\mathrm{N}$-dador utilizado. Para ambos compuestos, el lado construido con pireno-bis-NHC mide $13 \AA$, mientras que el lado conectado con el ligando bidentado N-dador mide $7 \AA$ para $\mathbf{1}$, y $11 \AA$ 
para 2. Ambos complejos fueron utilizados para la encapsulación de hidrocarburos policíclicos aromáticos (PAH). La capacidad de formar complejos de asociación de las diferentes cajas estaba claramente determinada por las dimensiones de la misma, por lo que la caja pequeña, $\mathbf{1}$, era capaz de encapsular sólo una única molécula, mientras que $\mathbf{2}$ era capaz de albergar hasta dos moléculas de PAH. Los valores de las constantes de asociación calculados por espectroscopía de ${ }^{1} \mathrm{H}$ RMN en acetona deuterada, indican que el orden de la fuerza de enlace es el siguiente: perileno < naftaleno < fenantreno < antraceno < pireno < trifenileno, con constantes que van desde 130-4400 $\mathrm{M}^{-1}$ en el caso de $\mathbf{1}$. En el caso de 2 , se obtuvieron constantes de asociación más pequeñas. La tendencia indica que los $\mathrm{PAH}$ más grandes muestran una mayor fortaleza de enlace que los PAH más pequeños, esto se debe a que su mayor tamaño favorece un mayor solapamiento. En el caso del perileno, la constante es tan pequeña porque su tamaño excede las dimensiones de la cavidad. Paralelamente, en otro tipo de experimentos similares, demostramos que 1 es capaz de extraer completamente todo el pireno de una solución de este PAH en heptano, ilustrando que dicho complejo puede ser utilizado como extractor de pireno.

Tras la preparación de $\mathbf{1}$ y $\mathbf{2}$ y el estudio de sus propiedades host-guest, nuestro objetivo fue la preparación de receptores tridimensionales con una mayor cavidad, para así poder encapsular moléculas tridimensionales de mayor tamaño, como por ejemplo fulerenos. Por consiguiente, el prisma trigonal 3 fue obtenido por combinación de tres ligandos pireno bisimidazolilideno y dos tris-(4-piridil) triazinas. La estructura obtenida por difracción de rayos-X de la molécula (Figura 1) revela que la caja posee una cavidad interna con un volumen de $1028 \AA^{3}$, con unas dimensiones adecuadas para la encapsulación de moléculas 3D, tales como fulerenos 
(Esquema 2). Esta caja presenta una complejación selectiva sobre el $\mathrm{C}_{70}$ en presencia de $\mathrm{C}_{60}$, por lo que puede ser considerada como un posible agente separador en la purificación de mezclas de fulerenos.

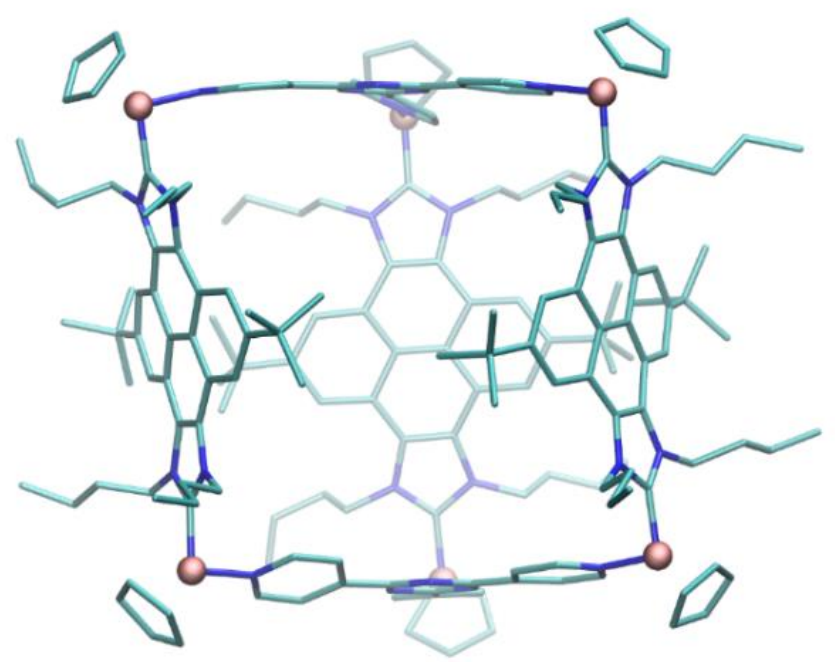

Figura 1: Estructura de 3 obtenida por difracción de rayos-X (los átomos de hidrógeno y los contraiones han sido omitidos por claridad).

La determinación de las constantes de asociación de 3 con $\mathrm{C}_{60}$ and $\mathrm{C}_{70}$ fue calculada mediante espectroscopía de ${ }^{1} \mathrm{H}$ RMN en una mezcla acetona/1,2diclorobenceno a diferentes temperaturas. Esto nos permitió calcular los parámetros termodinámicos asociados a la encapsulación, utilizando la ecuación de Van't Hoff. Los valores obtenidos fueron: $\Delta \mathrm{H}=3.1 \mathrm{kcal} / \mathrm{mol} \mathrm{y}$ $\Delta \mathrm{S}=27 \mathrm{cal} / \mathrm{molK}$ para el $\mathrm{C}_{60}$ y $\Delta \mathrm{H}=3.8 \mathrm{kcal} / \mathrm{mol} \mathrm{y} \Delta \mathrm{S}=34 \mathrm{cal} / \mathrm{molK}$ para el $\mathrm{C}_{70}$. El proceso es favorable entrópicamente debido a la desolvatación del receptor y de la molécula encapsulada. $\mathrm{El}$ proceso con $\mathrm{C}_{70}$ presenta un valor de $\Delta \mathrm{S}$ mayor debido a que hay un mayor número de moléculas de disolvente enlazadas al $\mathrm{C}_{70}$ en proporción al $\mathrm{C}_{60}$. El hecho de que el proceso sea endotérmico se explica por las grandes entalpías de solvatación de ambos. 
El complejo cuadrado de paladio 4 fue obtenido en una reacción one-pot combinando la sal de pireno-bis-imidazolio y el $[\mathrm{Pd}(\text { allyl }) \mathrm{Cl}]_{2}$ en acetonitrilo, en presencia de $\mathrm{AgBF}_{4}$ y $\mathrm{Cs}_{2} \mathrm{CO}_{3}$. Esta arquitectura molecular puede ser descrita como un metalo-cuadrado, pese a que la superficie plana poliaromática de los cuatro fragmentos pireno genera una caja cúbica macrocíclica tridimensional, más que bidimensional. Este compuesto de paladio fue utilizado en la encapsulación de fulerenos $\mathrm{C}_{60}$ y $\mathrm{C}_{70}$, y las constantes de asociación fueron calculadas mediante espectroscopía de ${ }^{1} \mathrm{H}$ RMN en 1,2-diclorobenceno a diferentes temperaturas. Los resultados obtenidos muestran que el receptor presenta una mayor afinidad por el fulereno más grande $\mathrm{C}_{70}$.
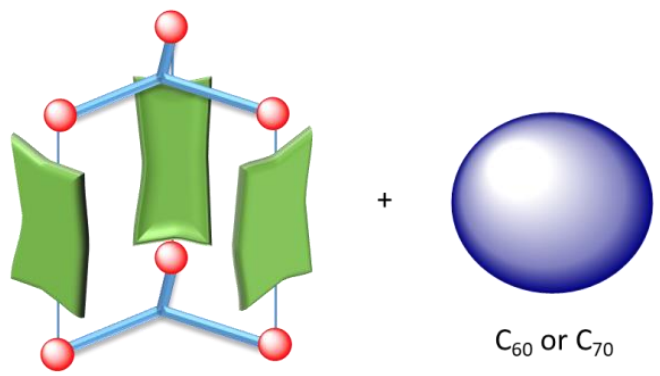

\section{$1,2-\mathrm{DCB}$}

Esquema 2: Representación esquemática de a encapsulación de fulerenos dentro de $\mathbf{3}$ en 1,2-diclorobenceno.

Los parámetros termodinámicos hallados para la encapsulación de $\mathrm{C}_{60}$ fueron $\Delta \mathrm{H}=1.7 \mathrm{kcal} / \mathrm{mol}$ y $\Delta \mathrm{S}=22 \mathrm{cal} / \mathrm{molK}$. Para la encapsulación de $\mathrm{C}_{70}$, los valores obtenidos fueron $\Delta \mathrm{H}=3.9 \mathrm{kcal} / \mathrm{mol} \mathrm{y} \Delta \mathrm{S}=34 \mathrm{cal} / \mathrm{molK}$. Los valores de las entalpías de asociación tan pequeños pueden explicarse debido a la gran entalpía de solvatación de los fulerenos en o-diclorobenceno. 
Las estructuras de la molécula de caja 4 vacía, así como con fulereno $\mathrm{C}_{60} \mathrm{y}$ $\mathrm{C}_{70}$ encapsulados fueron obtenidas mediante difracción de rayos-X (Figura 2). Estas estructuras muestran que el metalo-cuadrado no sólo es flexible, sino que adapta su forma y tamaño al fulereno encapsulado. Esto se consigue mediante la compresión o expansión de la estructura doblando el fragmento pireno para maximizar el solapamiento con la superficie convexa de los fulerenos.
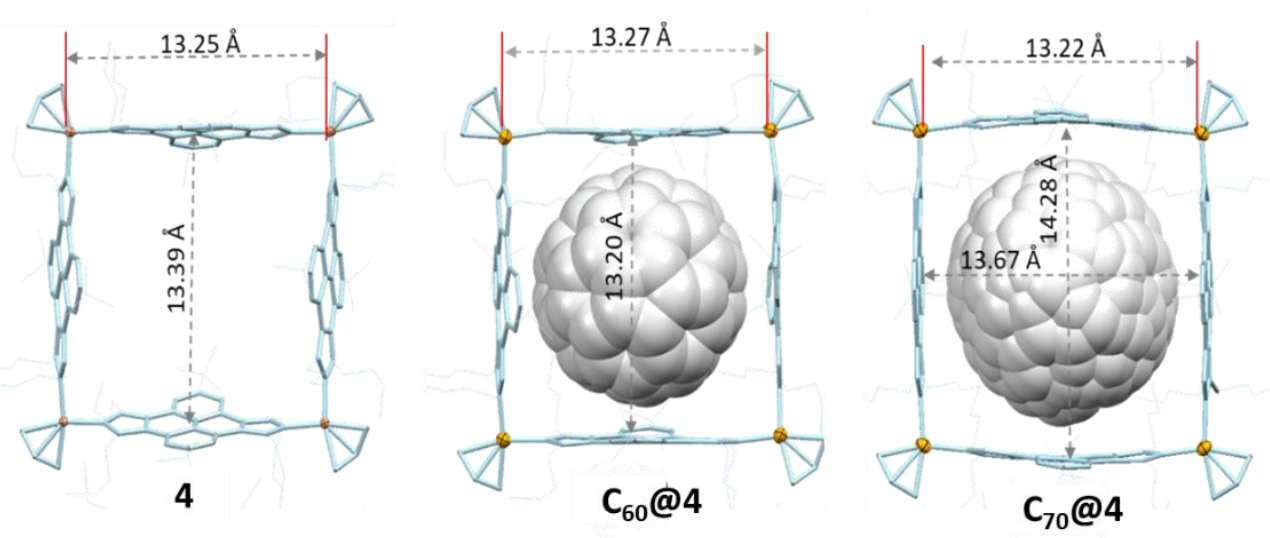

Figura 2. Estructuras de difracción de rayos-X de 4 (izquierda), $\mathrm{C}_{60} @ \mathbf{4}$ (centro), y $\mathrm{C}_{70} @ \mathbf{4}$ (derecha). Los átomos de hidrógeno, contraniones y moléculas de disolvente han sido omitidas por claridad.

Una característica muy atractiva de los complejos de asociación $\mathrm{C}_{60} @ \mathbf{4}$ y $\mathrm{C}_{70} @ 4$ es que ambos se comportan como fotosensibilizadores en la generación de oxígeno singlete. Aprovechando esta propiedad, la caja con fulereno encapsulado es capaz e oxidar varios alquenos a temperatura ambiente a partir de luz visible con el oxígeno singlete generado a partir de air a presión atmosférica (Esquema 3). Tras medir el espectro de emisión del oxígeno singlete generado por los dos compuestos tras haber sido irradiados 
con luz visible, los rendimientos cuántos obtenidos han sido $\Phi_{\Delta}=0.23 \mathrm{y}$ 0.41, para el $\mathrm{C}_{60} @ \mathbf{4}$ y $\mathrm{C}_{70} @ \mathbf{4}$, respectivamente, lo que explicaría por qué el complejo $\mathrm{C}_{70} @ \mathbf{4}$ presenta una mayor actividad fotocatalítica con respecto al $\mathrm{C}_{60} @$ 4. Estos resultados son importantes porque sugieren que otros sistemas supramoleculares que contengan fulereno tienen el potencial de ser usados en reacciones catalíticas similares.

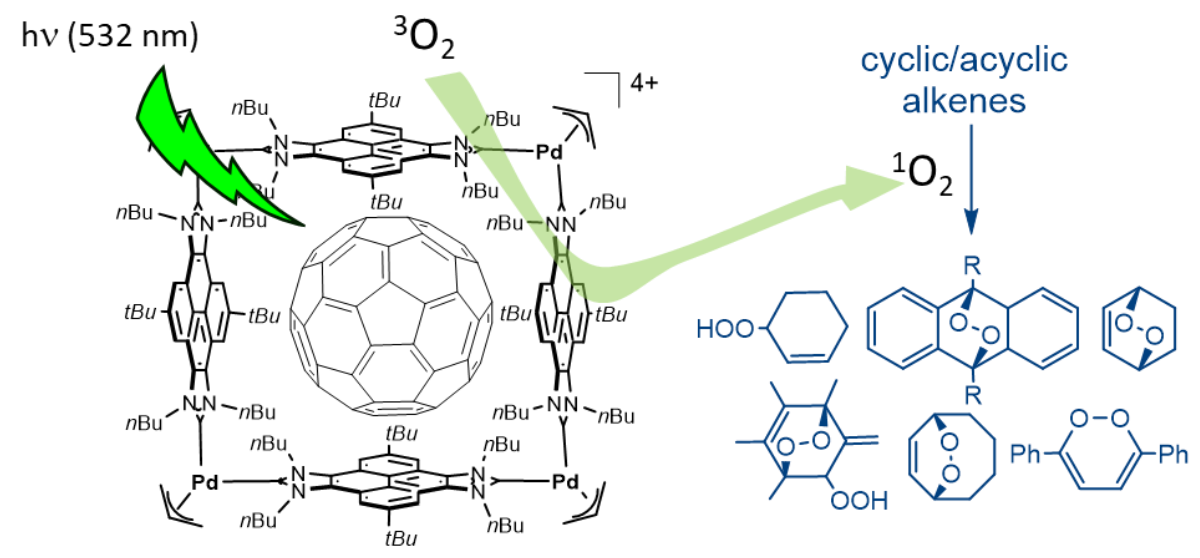

Esquema 3: Caja supramolecular 4 con fulereno encapsulado utilizada como fotocatalizador en la peroxidación de alquenos cíclicos y acíclicos.

La caja de paladio presenta el tamaño perfecto para la encapsulación de tres heteroguests (Figura 3). En el sistema se incluyen dos hidrocarburos policíclicos aromáticos ricos electrónicamente (pireno, trifenileno o coroneno), y una molécula de naftaleno tetracarboxidiimida (NTCDI). Esto posibilitó la formación de apilaciones quíntuples del tipo D-A-D-A-D. Este tipo de sistemas discretos con apilamiento- $\pi$ son muy interesantes, ya que establecen un modelo para la construcción de dispositivos electrónicos a nivel molecular. 
Las propiedades de encapsulación del metalo-cuadrado estan claramente definidas por la presencia de los fragmentos pireno, los cuales dotan al complejo de una forma tridimensional, comportándose de este modo como una antena efectiva para interacciones de apilamiento- $\pi$. Claramente, la introducción de las diferentes moléculas en la estructura de $\mathbf{4}$ está afectada por el efecto cooperativo, en el cual la presencia de las moléculas de PAH tiene una influencia positiva en la encapsulación de moléculas de NTCDI. A diferencia de cualquier otro sistema utilizado previamente en la encapsulación de múltiples heteroguests, nuestra caja supramolecular 4 es la primera en mostrar una estructura de forma cuadrada, mientras que todos los demás ejemplos de la literatura están basados en arquitecturas del tipo prisma trigonal cerradas.

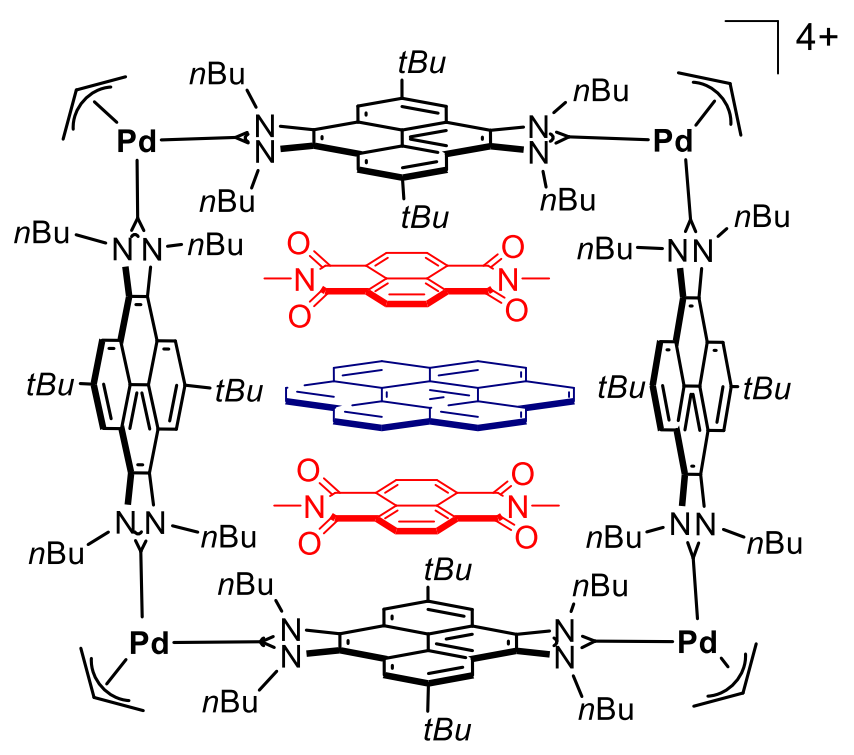

(G1+2G2)@[4]

Figura 3: Complejo de asociación host-guest en que la caja de paladio4 presenta encapsuladas tres moléculas. Las dos moléculas dibujadas en rojo son naftaleno tetracarboxidiimida (NTCDI) mientras que la molécula azul es un PAH, en este ejemplo hemos elegido coroneno. 
En resumen, hemos desarrollado una nueva familia de Complejos Organometálicos Supramoleculares (SOCs) con un gran potencial como receptores de diferentes moléculas de alto interés. Después de estudiar las propiedades host-guest de estos compuestos, hemos desarrollado una estrategia eficiente para el reconocimiento y encapsulación de moléculas de alto interés como los PAH y los fulerenos. Nuestros SOCs fueron utilizados como receptors de $\mathrm{PAH}$ presentando una correlación linear entre el número de electrones- $\pi$ y la Fortaleza de enlace así como la eficacia como extractor de PAH. Nuestros SOCs también fueron utilizados como receptores selectivos de fulerenos adaptando el tamaño de su cavidad a la forma del fulereno. Los SOCs fueron utilizados como fotosensibilizadores en la generación de oxígeno singlete a través de luz visible, siendo capaces de oxidar una gran variedad de alqueno fotocatalíticamente. Finalmente, los SOCs fueron capaces de albergar en su cavidad series de moléculas planas a través de interacciones del tipo apilamiento- $\pi$ con un efecto cooperativo. 

Hydrocarbon Receptors

\author{
Víctor Martínez-Agramunt, Sheila Ruiz-Botella, and Eduardo Peris*[a]
}

\begin{abstract}
Two nickel-cornered organometallic metalla-rectangles containing a pyrene-linked-di- $\mathrm{N}$-heterocyclic carbene have been prepared. The dimensions of one side of the rectangle were modulated by either using pyrazine or $4,4^{\prime}$-bipyridine. The two molecules were tested as hosts for the recognition of seven small polycyclic aromatic hydrocarbons (PAHs) in $\left[\mathrm{D}_{6}\right.$ ]acetone. By using ${ }^{1} \mathrm{H}$ NMR spectroscopy titrations, it could be established that the host-guest stoichiometries of the inclusion complexes formed were 1:1 for the pyrazine-based host, and 1:2 for the host containing bipyridine, in accordance with the larger dimensions of the latter. The molecular structure of the inclusion complex consisting
\end{abstract}

of the bipyridine-containing host and pyrene was determined by X-ray crystallography, which confirms the 1:2 host-guest stoichiometry of this species. The determination of the association constants indicate that the binding strengths are in the order: Perylene $<$ naphthalene $<$ phenanthrene $<$ anthracene $<$ pyrene $<$ triphenylene, ranging from $130-4400 \mathrm{M}^{-1}$ in the case of the smaller host, thus indicating that larger PAHs show higher binding strengths than smaller ones, except for the case of perylene, which exceeds the size for an optimum dimensional fitting within the cavity. As a proof of concept, the pyrazine host was used as a PAHscavenger in heptane.

\section{Introduction}

The basis for metallo-supramolecular design is the availability of rigid ligands with two or more binding sites, which in combination with suitable metals form symmetrical structures with a variety of shapes and sizes. ${ }^{[1]}$ Supramolecular coordination complexes $(\mathrm{SCCS})^{[2]}$ are often referred to as "molecular flasks", ${ }^{[3]}$ because they show well-defined nanoscopic cavities. It is precisely the presence of such cavities that makes SCCs suitable for important applications in catalysis, ${ }^{[4]}$ molecular recognition, ${ }^{[5]}$ the stabilization of highly reactive species, ${ }^{[6]}$ and as drug delivery/release vectors. ${ }^{[7]}$

The structural outcome of metallo-supramolecular synthesis is largely dependent on the nature of the metal ions and ligands. From a design perspective, the ligand is arguably considered as the most important component, because its topological features and binding abilities determine the size, geometry and functionality of the resulting metallo-supramolecules. This, combined with the predictable and well-defined coordination geometries of transition metals, gives metallo-supramolecules some advantages over traditional organic receptors, ${ }^{[8]}$ which often require highly sophisticated multistep synthetic procedures to achieve similar goals.

\footnotetext{
[a] V. Martinez-Agramunt, S. Ruiz-Botella, Prof. E. Peris Institute of Advanced Materials (INAM)

Universitat Jaume I Av. Vicente Sos Baynat s/n

Castellón 1271 (Spain)

E-mail: eperis@uji.es

(D) be found under:

http://dx.doi.org/10.1002/chem.201700703.
}

Most of the known metallo-supramolecular molecules are based on the use of $\mathrm{N}$ - or O-donor Werner-type polydentate ligands. Only recently, organometallic ligands -largely based on poly- $\mathrm{N}$-heterocyclic carbenes $(\mathrm{NHCs})^{[9]}$ - have been used for the preparation of a diverse type of SCCs, including molecular squares, rectangles and triangles, ${ }^{[10]}$ cylinders ${ }^{[11]}$ and organometallic polymers. ${ }^{[12]}$ Most of the known organometallic molecular squares and rectangles are based on the use of the well-known benzo-di(imidazolylidene) ligand ( $\mathbf{A}$ ) described by Bielawski and co-workers in 2005. ${ }^{[12 e, 13]}$ The benzo-di(oxazolylidene) ligand (B), described by Hahn and co-workers, also allowed for the preparation of a number of molecular squares. ${ }^{[10 d, e, 14]}$ The same group recently described an example of a $\mathrm{M}_{4} \mathrm{~L}_{4}$ molecular square with four bridging benzo-di(imidazolylidene)s, which was obtained by a single-step procedure. ${ }^{[15]}$ These examples demonstrate the great potential of Janus-diNHCs for the construction of metallo-supramolecular assemblies, but also illustrate the limited number of organometallic ligands that are currently available for preparing metallo-supramolecular assemblies. In fact, the use of either A or B establishes a metal-to-metal separation of $10.4 \AA$, which in most cases is too small to build cavities of the appropriate size for hosting organic guests. This may be the reason why none of the aforementioned organometallic metallo-supramolecules have been used as receptors for organic molecules; this may also explain why organometallic host-guest chemistry is so rare, despite the increasing number of known organometallic assemblies. During the last few years, we developed a series of Janus di-NHC ligands in order to construct SCCs with longer metal-to-metal distances. ${ }^{[16]}$ We also found that these di-NHCs with extended polyaromatic linkers imparted unique catalytic 
Chem. Eur. J. 23 (2017) 6675-6681

\title{
Nickel-cornered molecular rectangles as polycyclic aromatic hydrocarbon receptors
}

\author{
V. Martínez-Agramunt ${ }^{\text {a }}$, S. Ruiz-Botella ${ }^{\text {a }}$, and E. Peris ${ }^{\text {a* }}$ \\ ${ }^{a}$ Institute of Advanced Materials (INAM). Av. Vicente Sos Baynat s/n. \\ Universitat Jaume I, 12071 Castellón. Spain.
}

\begin{abstract}
Two nickel-cornered organometallic metalla-rectangles containing a pyrenelinked-di-N-heterocyclic carbene have been prepared. The dimensions of one of the sides of the rectangle was modulated by either using pyrazine of 4,4 'bipyridine. The two molecules were tested as hosts for the recognition of seven small polycyclic aromatic hydrocarbons (PAHs) in acetone-d6. By using ${ }^{1} \mathrm{H}$ NMR titrations, it could be established that the host:guest stoichiometries of the inclusion complexes formed were 1:1 for the pyrazinebased host, and 1:2 for the host containing bipyridine, in accordance with the higher dimensions of the latter one. The molecular structure of the inclusion complex of the bipyridine-containing host and pyrene was determined by $\mathrm{X}$ ray diffractometry and confirms the 1:2 host:guest stoichiometry of this
\end{abstract}


species. The determination of the association constants indicated that the binding strength are in the order perylene < naphthalene < phenanthrene < anthracene < pyrene < triphenylene, ranging from $130-4400 \mathrm{M}^{-1}$ for the case of the smaller host, thus indicating that larger PAHs show a higher binding strength than smaller ones, except for the case of perylene, which exceeds the size for an optimum dimensional fitting within cavity. As a proof of concept, the pyrazine host was used as a PAH-scavenger in heptane.

\section{Introduction}

The basis for metallosupramolecular design is the availability of rigid ligands with two or more binding sites, which in combination with suitable metals form symmetrical structures with a variety of shapes and sizes. ${ }^{[1-5]}$ Supramolecular coordination complexes $(\mathrm{SCCs})^{[6,7]}$ are often referred to as "molecular flasks", ${ }^{[8-10]}$ because they show well-defined nanoscopic cavities. It is precisely the presence of such cavities that makes SCCs have important applications in catalysis, ${ }^{[11-15]}$ molecular recognition, ${ }^{[16-18]}$ for the stabilization of highly reactive species, ${ }^{[19]}$ and as drug delivery/release vectors. ${ }^{[20-26]}$

The structural outcome of metallosupramolecular synthesis is largely dependent on the nature of the metal ions and ligands. From the design perspective, the ligand is arguably considered as the most important block, because its topological features and binding abilities determine the size, geometry and functionality of the resulting metallasupramolecules. This, combined with the predictable and well-defined coordination geometries of transition metals, gives metallosupramolecules some advantages over 
traditional organic receptors, ${ }^{[27-33]}$ which for achieving similar goals often require highly sophisticated multistep synthetic procedures.

Most of the known metallosupramolecular molecules are based on the use of $\mathrm{N}$ - or O-donor Werner-type polydentate ligands, and only recently, organometallic ligands -largely based on poly-N-heterocyclic carbenes $(\mathrm{NHCs})^{[34,35]}$ - have allowed the preparation of a diverse type of SCCs, including molecular squares, rectangles and triangles, ${ }^{[36-42]}$ cylinders ${ }^{[43-49]}$ and organometallic polymers. ${ }^{[50-59]}$ Most of the known organometallic molecular squares and rectangles, are based on the use of the well-known benzo-di(imidazolylidene) ligand (A) described by Bielawski and coworkers in 2005. ${ }^{[54,60]}$ The benzo-di(oxazolylidene) ligand (B) described by Hahn and co-workers also allowed the preparation of a number of molecular squares. ${ }^{[39,40,61,62]}$ The same group recently described an example of a $\mathrm{M}_{4} \mathrm{~L}_{4}$ molecular square with four bridging benzobisimidazolylidenes, obtained by a single-step procedure. ${ }^{[63]}$ These examples demonstrate the great potential of Janus-di-NHCs for the construction of metallosupramolecular assemblies, but also illustrate the limited number of organometallic ligands that are currently available for preparing metallosupramolecular assemblies. In fact, the use of either A or B, allows to establish a metal-to-metal separation of $10.4 \AA$, which in most cases is too small for building cavities of the appropriate size for hosting organic guests. This may be the reason why none of the above mentioned organometallic metallosupramolecules have been used as receptors for organic molecules, and probably this also explains why organometallic host-guest chemistry is so rare, despite the increasing number of known organometallic assemblies. During the last few years, we developed a series of Janus di-NHC ligands that should allow constructing SCCs with longer metal-to-metal distances. ${ }^{[64-66]}$ We also found that these di- 
NHCs with extended polyaromatic linkers imparted unique catalytic properties that we ascribed to supramolecular interactions between aromatic substrates and the polyaromatic cores of the ligands. ${ }^{[67]}$ Because rectanglelike species have demonstrated unique binding abilities and selectivities for planar aromatic guests, ${ }^{[28]}$ we thought that our nanosized Janus-di-NHCs may introduce interesting applications for host-guest chemistry, and for this reason we became interested in developing a series of molecular rectangles for the selective recognition of organic molecules. In particular, we sought that the structural features of the pyrene-linked di-NHC ligand C (Scheme $1),{ }^{[64]}$ could be used for the preparation of molecular rectangles with the
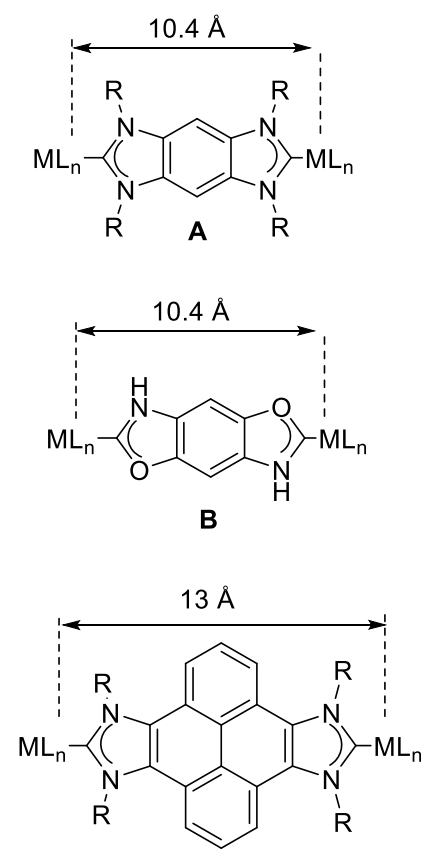

C

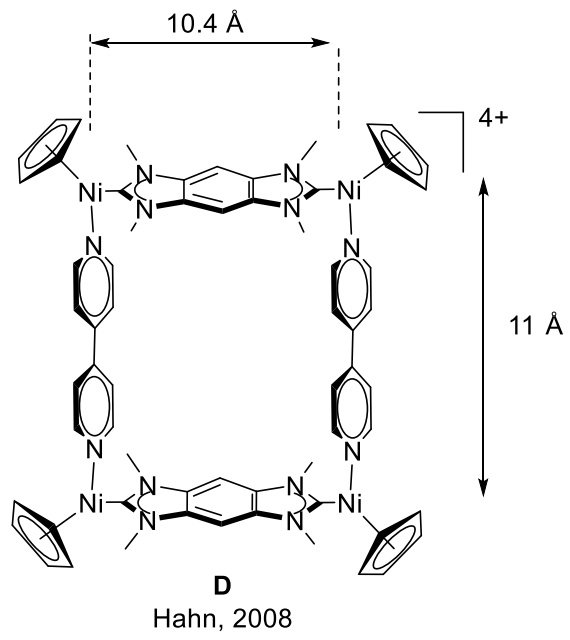

Hahn, 2008

Scheme 1. A and B, Janus di-NHC used for the preparation of known molecular rectangles. C, di-NHC used in this work. D, previously published Ni-cornered rectangle. 
potential to recognize polycyclic aromatic hydrocarbons (PAHs) by means of $\pi-\pi$ stacking interactions. Low molecular weight PAHs ranging from naphtalene ( $\mathrm{Mw}=128.16)$ to coronene $(\mathrm{Mw}=300.36)$ are hazardous materials that have gathered significant environmental concern. ${ }^{\text {[68-71] }}$ Unsubstituted lower PAHs (2-3 rings) exhibit acute toxicity, while many of the 4- to 7-ring PAHs are less toxic but carcinogenic to a variety of organisms. Therefore, there is a great interest in developing host molecules for PAH detection. Several metallasupramolecular rectangles have been used for the recognition of PAHs, ${ }^{[72-79]}$ although all the examples known refer to the Werner-type coordination cages with second and third row transition metals. Based on these precedents, herein we describe the preparation of two nickel-cornered molecular rectangles based on the pyrene-bisimidazolylidene ligand $\mathrm{C}$, for the selective recognition of a range of small PAHs.

\section{Results and Discussion}

The synthetic procedure that we used is depicted in Scheme 2. The reaction of the pyrene-bisimidazolium diiodide 1 with nickelocene in a mixture of dimethylformamide/tetrahydrofuran afforded the dimetallic complex 2 in 73 $\%$ yield. Then the reaction of complex 2 with pyrazine and two equivalents of AgBF4 leads to the air-stable tetra-nickel complex $[3]\left(\mathrm{BF}_{4}\right)_{4}$ in $75 \%$ yield. By following a similar procedure, but adding 4,4'-bipyridine instead of pyrazine, complex [4](BF $)_{4}$ was obtained in $80 \%$ yield. Complexes 2 , $[3]\left(\mathrm{BF}_{4}\right)_{4}$ and $[4]\left(\mathrm{BF}_{4}\right)_{4}$ were characterized by NMR spectroscopy, mass spectrometry and elemental analysis.

The molecular structure of complex 2 was confirmed by single crystal X-ray diffraction (Figure 1). The molecule consists of a pyrene-linked-di- 
imidazolylidene connecting two nickel centers. The coordination sphere about the metals is completed by one iodine and one cyclopentadienyl ligand. The relative disposition of the two metal complex fragments is anti,

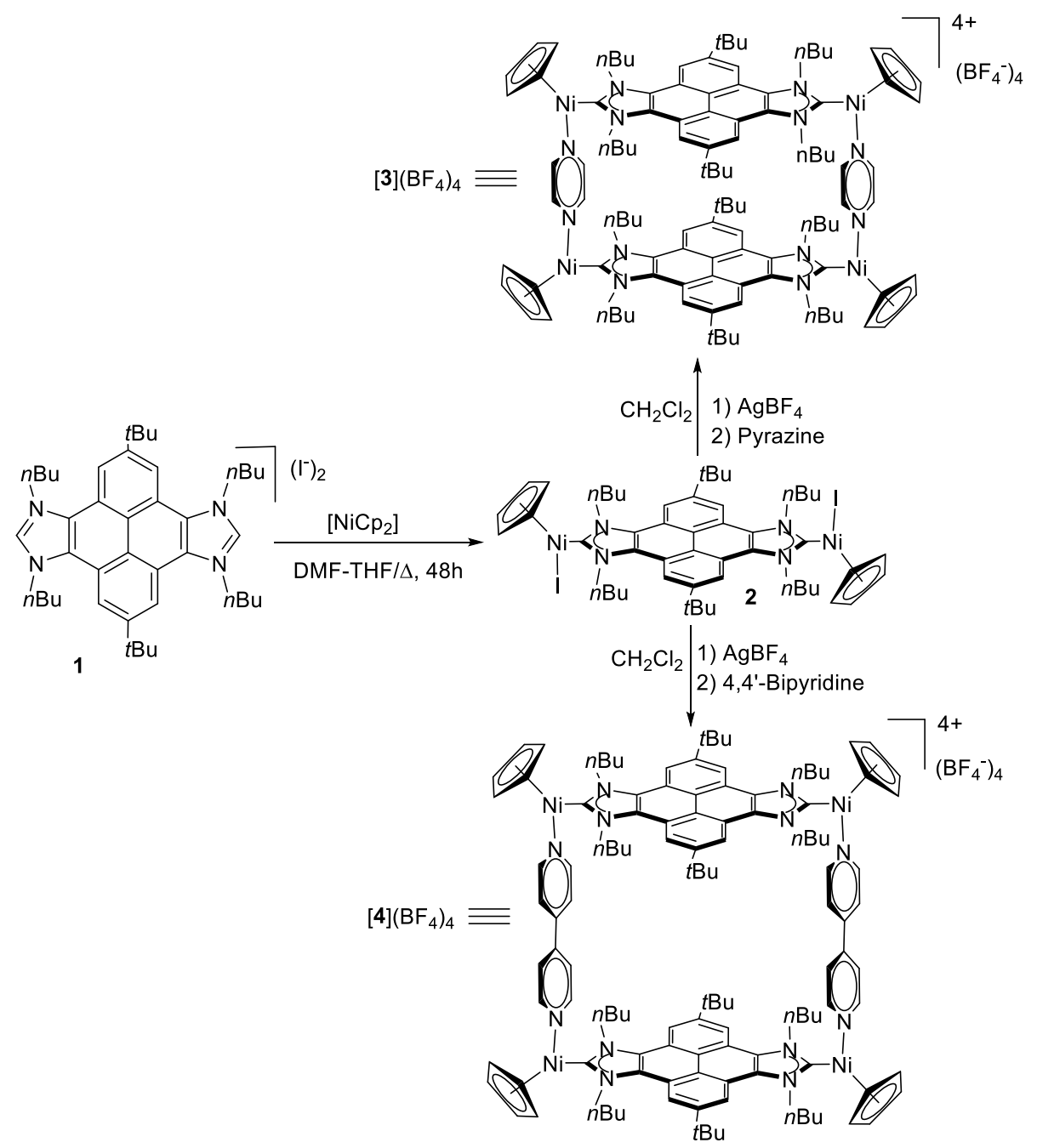

with the two iodine ligands pointing at opposite directions.

Scheme 2. Synthesis of nickel-cornered rectangles.

The metal complex fragments are oriented in the less hindered position, with the Ni-I bonds quasi-perpendicular with respect to the plane of the 
imidazolylidene. The Ni-C(carbene) distance is $2.131 \AA$, and the separation between the two metals is $12.989 \AA$, similar to the M-M distances of other dimetallic complexes bridged by the same pyrene-di-imidazolylidene ligand. ${ }^{[64,80]}$

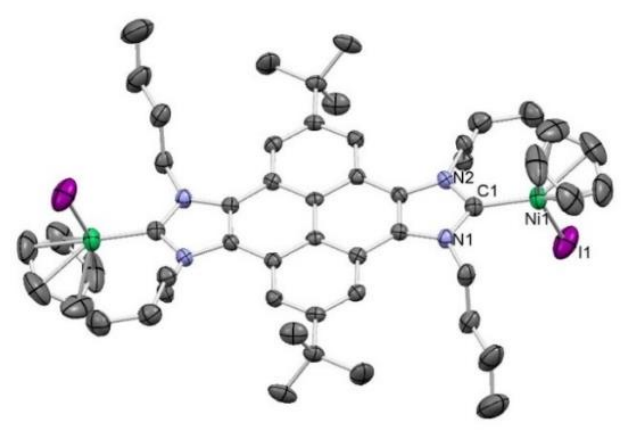

Figure 1. Molecular structure of complex 2. Ellipsoids at $50 \%$ of probability. Hydrogen atoms and solvent (chloroform) omitted for clarity. Selected bond distances $(\AA)$ and angles ( ${ }^{\circ}$ : Ni(1)-C(1) 1.890(3), Ni(1)-I(1) 2.4838(6), C(1)-Ni(1)-I(1) 96.60(11).

We then tested our molecular rectangles $[3]\left(\mathrm{BF}_{4}\right)_{4}$ and $[4]\left(\mathrm{BF}_{4}\right)_{4}$ for the recognition of small polycyclic aromatic hydrocarbons (PAHs). Our initial guess was that the metal-to-metal distance established by the pyrene-diimidazolylidene ligand of $\approx 13 \AA$, should allow establishing a size cutoff of PAHs of up to pyrene or triphenylene (4 rings), while larger PAHs such as coronene (7 rings), with a larger size of $11.3 \AA$, should not fit inside the cavity of either of the two rectangles. The choice of the N-heterocyclic linker (pyrazine or 4,4'-bipyridine), should determine whether one or two layers of the polyaromatic guests are accommodated inside the cavity, according to the Ni-Ni distances established along the heterocyclic linkers, which we estimated as 7 and $11 \AA$, for pyrazine and 4,4`-bipyridine, respectively. We 
also envisioned that the tetracationic nature of the two rectangles, together with the presence of the pyrene linker, should favor the incorporation of electron-rich PAHs through $\pi$ - $\pi$-stacking interactions.

The recognition abilities of complexes $[3]\left(\mathrm{BF}_{4}\right)_{4}$ and $[4]\left(\mathrm{BF}_{4}\right)_{4}$ were studied by ${ }^{1} \mathrm{H}$ NMR titration experiments, by monitoring the variation of the chemical shifts of the signals of the ligands of the complexes upon addition of solutions of the different polyaromatic guests. For our studies we chose acetone-d6, because it provided the best solubility for hosts and guests, together with ${ }^{1} \mathrm{H}$ NMR spectra with sharp signals of the hosts. Most studies for the determination of the association constants between coordination cages and PAHs have been developed in acetonitrile, but the recent shortage of this solvent and its higher toxicity makes acetone a much greener and convenient alternative, ${ }^{[81,82]}$ especially if further practical applications are pursued. The titrations were performed at constant concentrations of the hosts (typically $1 \mathrm{mM}$ ). In general, the addition of the solutions of the guests induced important perturbations in the ${ }^{1} \mathrm{H}$ NMR spectra, indicating the formation of inclusion complexes that showed fast kinetics on the NMR timescale. However, when $[3]\left(\mathrm{BF}_{4}\right)_{4}$ was used as host, the NMR titrations with the larger PAHs, produced a significant broadening of the signals of the host, suggesting that the formation of the aggregates showed a kinetics occurring in the range of the NMR timescale. This observation is in agreement with the findings reported by Stoddart and co-workers, in the sense that smaller PAHs form inclusion complexes faster than the larger ones. ${ }^{[83]}$ Figure 2 shows the ${ }^{1} \mathrm{H}$ NMR spectra resulting from the titration of [3] $\left(\mathrm{BF}_{4}\right)_{4}$ with naphthalene. As can be observed, the addition of guest to the host solution produces a significant upfield shift of the signal due to the protons of the host pyrene linker, together with a gradual downfield shift of 
the signal due to the protons of the pyrazine. This behaviour clearly confirms that the guest occupies the hollow gap of the molecule, which is the only region where the chemical shifts of the two linkers of $[3]\left(\mathrm{BF}_{4}\right)_{4}$ can be
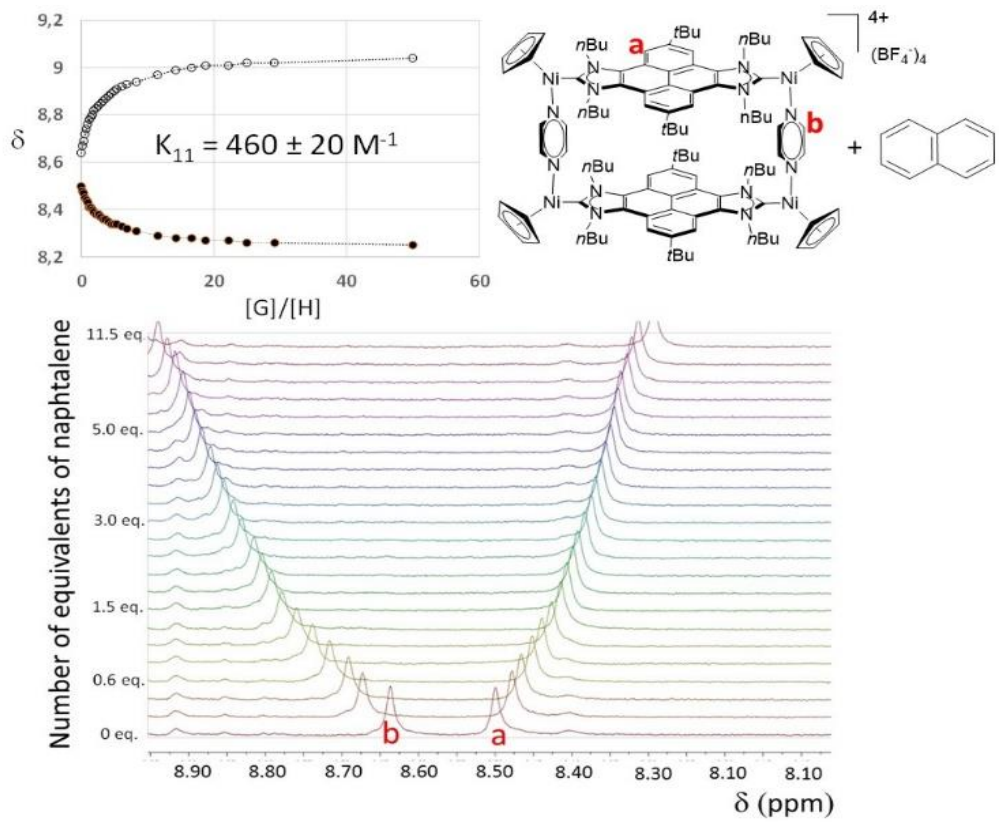

simultaneously perturbated.

Figure 2. Representative region of the ${ }^{1} \mathrm{H}$ NMR (400 MHz) spectra of the titration of [3] $\left(\mathrm{BF}_{4}\right)_{4}$ with naphtalene. The spectra were recorded at a constant concentration of $[3]\left(\mathrm{BF}_{4}\right)_{4}(1 \mathrm{mM})$. The plot represents the binding isotherm, with the resulting association constant obtained from the nonlinear regression analysis.

The stoichiometry of the host:guest complexes formed was found to be 1:1, for all the cases in which host $[3]\left(\mathrm{BF}_{4}\right)_{4}$ was used. This assumption was based on the analysis of the binding isotherms resulting from the titrations of host $[3]\left(\mathrm{BF}_{4}\right)_{4}$ with all the polyaromatic guests. In all cases the 1:1 stoichiometry gave the lowest residuals compared to any other stoichiometry. ${ }^{[84]}$ A Job plot was also carried out to confirm the formation of the 1:1 complex (Figure 3 shows a representative Job plot for the case of 
[3] $\left(\mathrm{BF}_{4}\right)_{4}$ and triphenylene). The association constants (K11) were calculated by global nonlinear regression analysis. ${ }^{[84,85]}$
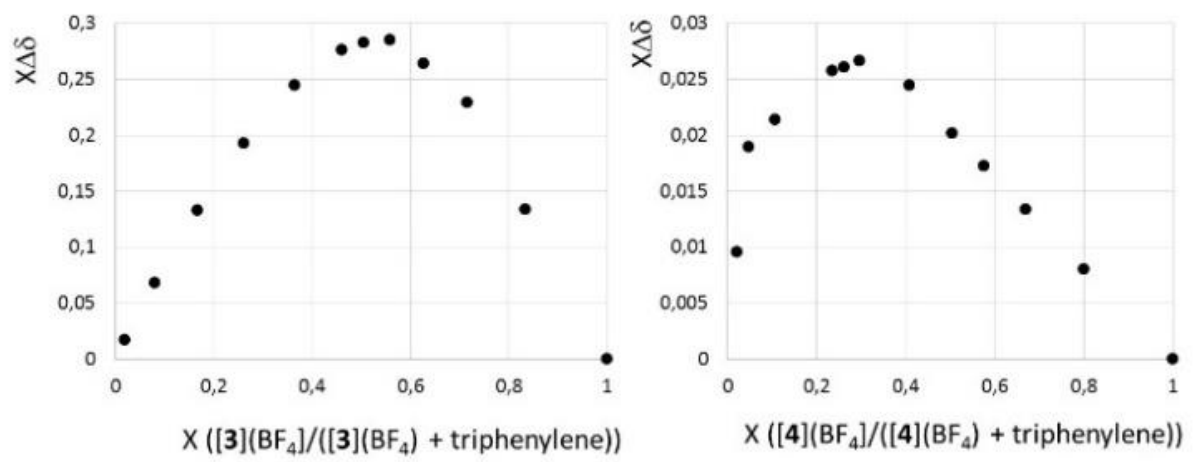

Figure 3. Left: Job plot for the inclusion complex formed between $[3]\left(\mathrm{BF}_{4}\right)$ and triphenylene (1:1 stoichiometry). Right: Job plot for the inclusion complex formed between $[4]\left(\mathrm{BF}_{4}\right)$ and triphenylene (1:2 stoichiometry).

A different situation arises when $[4]\left(\mathrm{BF}_{4}\right)_{4}$ is used as host. For this molecule, we performed the titrations with pyrene and triphenylene. In both cases, the titration curves were best fitted to a 1:2 host:guest stoichiometry. The corresponding Job plots also confirmed this stoichiometry (Figure 3). This result is consistent with the larger size of the cavity formed when $4,4^{4}$ bipyridine is used instead of pyrazine, which should allow two guests molecules to be accommodated within the hollow space of the rectangle.

The analysis of the ${ }^{1} \mathrm{H}$ NMR spectra also allowed determining the host:guest association constants, which are shown in Table 1 . The results indicate that the binding affinities of the PAHs guests are in the order perylene < naphthalene < phenanthrene < anthracene < pyrene < triphenylene. The binding constants associated to $[4]\left(\mathrm{BF}_{4}\right)_{4}$ are in accordance with a classical stepwise non-cooperative binding, for which $\mathrm{K}_{11} \approx 4 \mathrm{~K}_{12}$, as expected for a situation where the binding sites are identical and independent of each 
other. ${ }^{[86-88]}$ It has to be taken into account that, despite the good fittings, the association constants related to $[4]\left(\mathrm{BF}_{4}\right)_{4}$ have to be taken as a crude estimation, due to their low values which indicate a very low degree of formation of the inclusion complexes along the titration.

Table 1. Association constants $\left(\mathrm{M}^{-1}\right)$ for the complexation of $[3]\left(\mathrm{BF}_{4}\right)_{4}$ and $[4]\left(\mathrm{BF}_{4}\right)_{4}$ with low molecular weight PAHs. ${ }^{a} \mathrm{~K}_{11}$ and $\mathrm{K}_{12}$ values calculated by global nonlinear regression analysis. ${ }^{[84,85]}$ Titrations were carried out using constant concentrations of host of $1 \mathrm{mM}$ in acetone-d6 at $298 \mathrm{~K}$. Errors refer to the regression fittings.

\begin{tabular}{cccccc} 
Entry & Host & Guest & $\mathrm{H}: \mathrm{G}$ & $\mathrm{K}_{11}$ & $\mathrm{~K}_{12}$ \\
\hline 1 & {$[3]\left(\mathrm{BF}_{4}\right)_{4}$} & naphthalene & $1: 1$ & $460 \pm 20$ & -- \\
2 & {$[3]\left(\mathrm{BF}_{4}\right)_{4}$} & phenanthrene & $1: 1$ & $1540 \pm 110$ & -- \\
3 & {$[3]\left(\mathrm{BF}_{4}\right)_{4}$} & anthracene & $1: 1$ & $2600 \pm 350$ & -- \\
4 & {$[3]\left(\mathrm{BF}_{4}\right)_{4}$} & triphenylene & $1: 1$ & $4400 \pm 500$ & -- \\
5 & {$[3]\left(\mathrm{BF}_{4}\right)_{4}$} & pyrene & $1: 1$ & $3450 \pm 400$ & -- \\
6 & {$[3]\left(\mathrm{BF}_{4}\right)_{4}$} & perylene & $1: 1$ & $130 \pm 25$ & -- \\
6 & {$[\mathbf{4}]\left(\mathrm{BF}_{4}\right)_{4}$} & triphenylene & $1: 2$ & $181 \pm 30$ & $40 \pm 10$ \\
7 & {$[\mathbf{4}]\left(\mathrm{BF}_{4}\right)_{4}$} & pyrene & $1: 2$ & $18 \pm 3$ & $4 \pm 1$ \\
8 & {$[3]\left(\mathrm{BF}_{4}\right)_{4}$} & coronene & -- & -- & - \\
\hline
\end{tabular}

The association constants shown by $[3]\left(\mathrm{BF}_{4}\right)_{4}$ are higher than those observed for $[4]\left(\mathrm{BF}_{4}\right)_{4}$, probably as a consequence of the closer distance between the two pyrene walls in $[3]\left(\mathrm{BF}_{4}\right)_{4}$, which facilitates an optimized $\pi$-stacking interaction with the planar PAHs molecules. According to Rebek's rule the binding between the host and the guest is expected to be favorable when the guest occupies about $55 \%$ of the host volume. ${ }^{[89]}$ However, this rule has exceptions when the structures are open to the exterior, as in a molecular rectangle. Also, it is difficult to make an estimation of the internal (or guestaccessible) volumes of our molecules $[3]\left(\mathrm{BF}_{4}\right)_{4}$ and $[4]\left(\mathrm{BF}_{4}\right)_{4}$. For hosts with 
very large portals, Stoddart found that the affinity between the host and the PAHs guest followed and approximately linear trend of increasing $\log \mathrm{Ka}$ values with increasing number of $\pi$-electrons in the guests. ${ }^{[83,90]}$ As the PAH $\pi$-electronrichness increases, the $\pi-\pi$ binding between host and guest becomes more effective, and the association constant increases. This situation is also observed for the affinity trends shown by $[3]\left(\mathrm{BF}_{4}\right)_{4}$, although in our case we found a best trend for the representation of the association constants against the number of guest $\pi$-electrons, as shown by the plot shown in Figure 4a. An excellent linearity is followed by guests in the range of 10-18 $\pi$-electrons, except for the case of phenanthrene, which probably deviates from the optimum face-to-face $\pi-\pi$ overlap with $[3]\left(\mathrm{BF}_{4}\right)_{4}$. These PAHs have the suitable size to fit within the gap of the host. Perylene, with $20 \pi$-electrons and a larger size than pyrene and triphenylene, exceeds the optimum volume to fit within the cavity of the host, so in this case the favorable $\pi-\pi$ stacking interactions may be accompanied by an unfavorable steric strain which turns into a reduced binding constant. The overall picture is that $[3]\left(\mathrm{BF}_{4}\right)_{4}$ behaves as an excellent host for the selective recognition of the smaller PAHs, with a higher affinity to the four-fused PAHs, triphenylene and pyrene. This selectivity is determined by the stereoelectronic nature of the PAHs, which establish clear electronic and size cutoffs. In a similar line, the plot of the maximum chemical shift differences of the protons of the pyrene core and the pyrazine ligand of host $[3]\left(\mathrm{BF}_{4}\right)_{4}$ reflects a similar trend (Figure $4 \mathrm{~b}$ ), although in this case the chemical shift differences found for the two 14e PAHs (phenanthrene and anthracene) are almost identical. In the case of perylene, the experimental value obtained is lower than the value estimated by regression analysis program (red dots in 
Figure 4b), because for this guest the NMR titration did not allow reaching to the point for which a saturation of the NMR signals is achieved.

a)

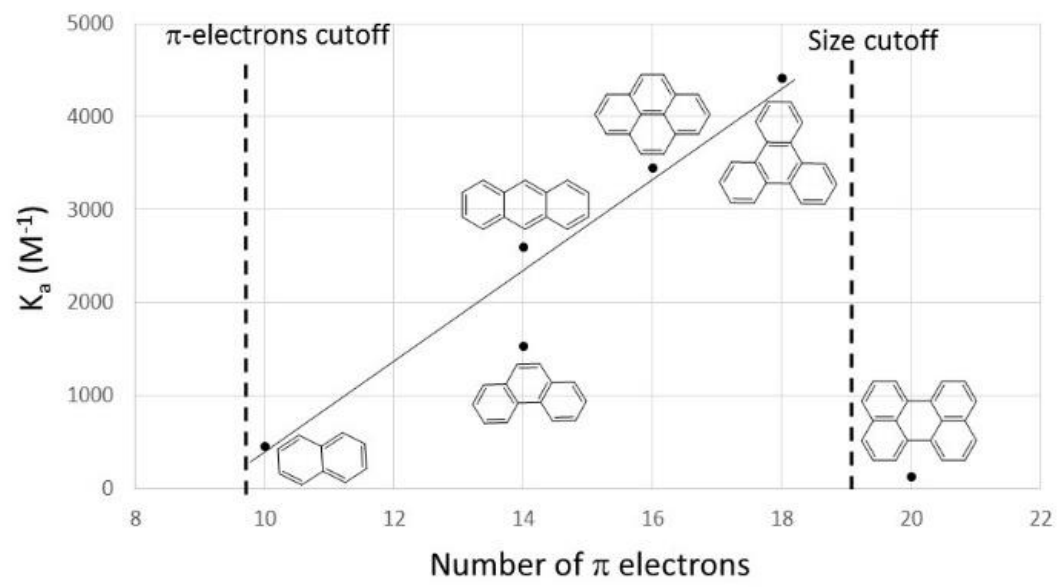

b)

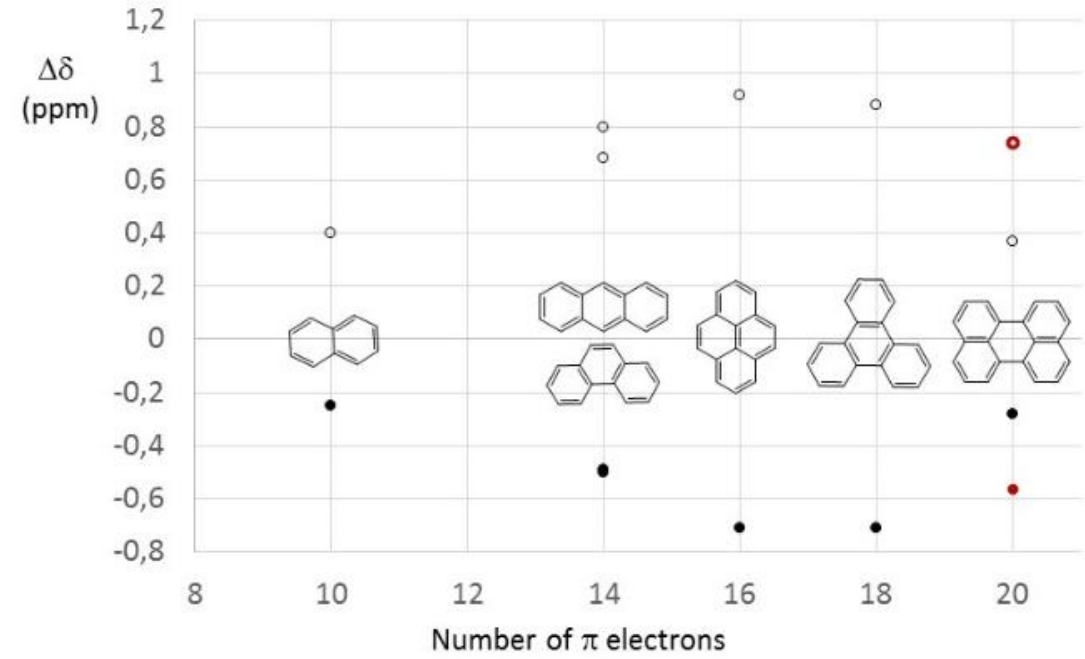

Figure 4. (a) Plot of the association constants $\left(\mathrm{K}_{\mathrm{a}}\right)$ in acetone- $d_{6}$ between $[3]\left(\mathrm{BF}_{4}\right)_{4}$ and the number of $\pi$-electrons of the six PAHs used in this study (the straight line is just to guide the eye). (b) Maximum chemical shift differences (experimental) plotted against the number of electrons present in the different PAHs. The values in red represent the estimated maximum chemical shift difference, as obtained from the non-linear regression fitting. 
Overall, the plot illustrates the combined effect of the binding affinities together with the shielding/deshielding effect of the PAH guests.

In the same direction, the $1 \mathrm{H} \mathrm{NMR}$ titrations carried out with coronene as guest, did not show any signal shifting, thus we assumed that our hosts do not show any binding affinity with coronene due to its larger size, which exceeds the hollow space of both hosts. Similarly, the titrations using benzene as guest, demonstrated that the affinity of our two metallarectangles to bind benzene is negligible. These findings illustrate the great selectivity of our rectangles to bind only to lower weight PAHs.

Single crystals suitable for $\mathrm{X}$-ray analysis of $[4]\left(\mathrm{BF}_{4}\right)_{4} \subset$ (pyrene $)_{2}$ were obtained by slow evaporation of a solution of the aggregate in acetone. The molecule crystallized in a triclinic P-1 space group. The metalla-rectangle is composed by two dinuclear $\left[\mathrm{Ni}_{2} \mathrm{Cp}_{2}(\mu \text {-pyrene-di-imidazolylidene })\right]^{2+}$ clips connected by two 4,4'-bipyridine ligands (Figure 5).

The Ni-Ni distances are 12.941 and $10.876 \AA$ through the pyrene-di-NHC and the 4,4'-bipyridine bridging ligands, respectively. The $\mathrm{N}-\mathrm{Ni}-\mathrm{C}$ angles are significantly larger than $90^{\circ}$, and the two parallel pyrene-di-NHC ligands are slightly displaced relative to each other. The metalla-rectangle contains two parallel-displaced molecules of pyrene, which are separated from each other by $3.682 \AA$. The plane formed by the pyrene molecules and the pyrene-core of the di-NHC ligand is $6.21^{\circ}$, and the average distance between these two fragments is $3.79 \AA$. These parameters indicate that an effective $\pi$ - $\pi$ stacking interaction is established both between the pyrene guest molecules, and between the pyrene guests and the pyrene core of the di-NHC ligand. The longest axis of the pyrene molecules are disposed at an angle of $29.71^{\circ}$ with respect to the axis formed by the two nickel centers linked by the di-NHC ligand, thus the pyrene molecules avoid the sterically strained situation that a 
parallel disposition should provide.
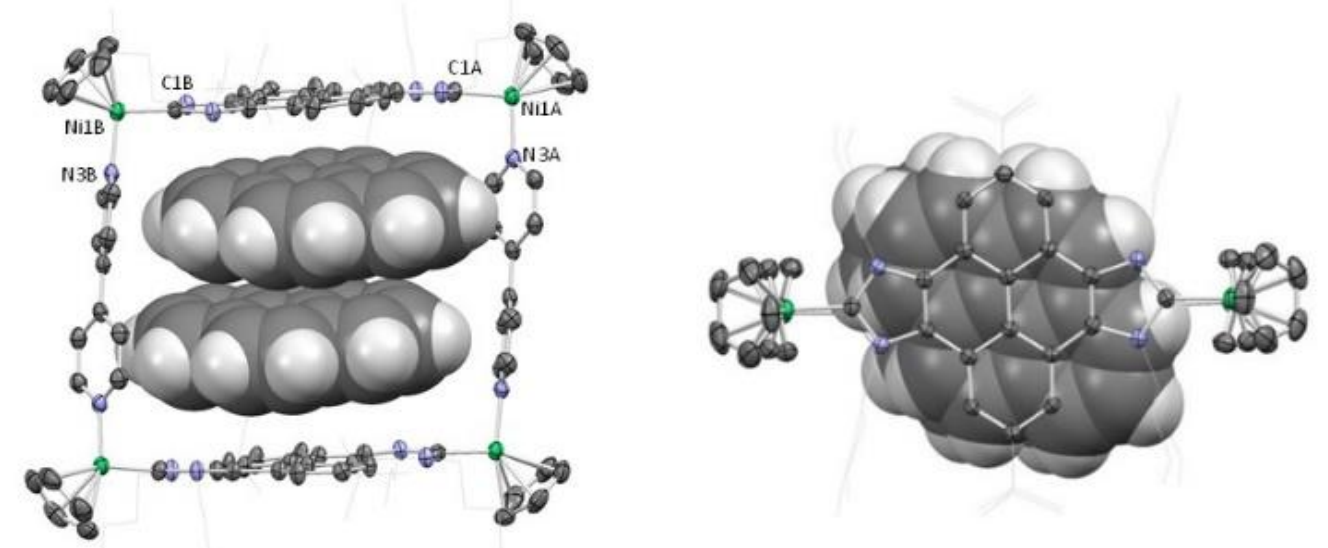

Figure 5. Two perspectives of the molecular structure of complex $[4]\left(\mathrm{BF}_{4}\right)_{4} \subset(\text { pyrene })_{2}$. Ellipsoids at $50 \%$ of probability. Hydrogen atoms, solvent (acetone) and counter-anions $\left(\mathrm{BF}_{4}{ }^{-}\right)$omitted for clarity. The molecules of pyrene are represented with the space-filling diagrams, and the $n$-butyl and $t$-butyl grups of $[4]\left(\mathrm{BF}_{4}\right)_{4}$ in the wireframe form. Selected bond distances $(\AA)$ and angles $\left({ }^{\circ}\right)$ : $\mathrm{Ni}(1 \mathrm{~A})-\mathrm{C}(1 \mathrm{~A}) 1.905(4), \mathrm{Ni}(1 \mathrm{~A})-\mathrm{N}(3 \mathrm{~A}) 1.908(3), \mathrm{Ni}(1 \mathrm{~B})-$ C(1B) $1.892(4), \mathrm{Ni}(1 \mathrm{~B})-\mathrm{N}(3 \mathrm{~B})$ 1.897(3), C(1A)-Ni(1A)-N(3A) 97.88(15), C(1B)-Ni(1B)$\mathrm{N}(3 \mathrm{~B})$ 94.46(16).

Finally, we tested if $[3]\left(\mathrm{BF}_{4}\right)_{4}$ as a PAH-scavenger. For this, we dissolved $1.1 \times 10^{-3}$ mmols of the PAH in heptane $(0,4 \mathrm{~mL})$, together with anisole as a nonbinding standard. For the experiment performed with pyrene, the irradiation of the solution with an UV lamp (365 nm) generates a strong blue emission due to the presence of the fluorescent PAH. Then [3] $\left(\mathrm{BF}_{4}\right)_{4}(1.3 \mathrm{x}$ $10^{-3}$ mmols) was added to the solution, and the suspension was sonicated during $3 \mathrm{~h}$. The UV irradiation of the resulting suspension showed that the emission disappeared, thus indicating that pyrene has been extracted from the heptane solution (Figure 6) by forming the insoluble inclusion complex $[3]\left(\mathrm{BF}_{4}\right)_{4} \subset$ pyene. 


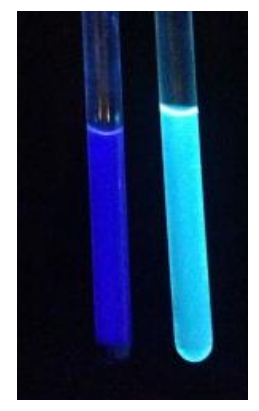

Figure 6. Samples irradiated with UV light $(365 \mathrm{~nm})$. Both tubes contain $1.1 \times 10^{-3} \mathrm{mmol}$ of pyrene in $0.4 \mathrm{~mL}$ of heptane. The tube on the left also contains $1.3 \times 10^{-3} \mathrm{mmol}$ of [3] $\left(\mathrm{BF}_{4}\right)$, and the picture was taken after $1 \mathrm{~h}$ of sonication. The image shows how the addition of $[3]\left(\mathrm{BF}_{4}\right)$ quenches the emission of pyrene.

In order to quantify the removal of pyrene, the solid was filtered off, and the filtrate solution was examined by ${ }^{1} \mathrm{H}$ NMR spectroscopy. The analysis indicated that pyrene was quasi-quantitatively removed from the original heptane solution (> 90\% removed, Figure 7).

In the case of the experiment carried out with $[3]\left(\mathrm{BF}_{4}\right)_{4}$ and naphtalene, the analysis of the solution after being sonicated for three hours indicated that less than $10 \%$ of naphthalene remained in the heptane solution, thus this smaller PAH was extracted in a similar extent as pyrene. In order to compare the extracting abilities of this scavenger, to the latter suspension containing $[3]\left(\mathrm{BF}_{4}\right)_{4} \subset$ naphtalene further pyrene $\left(1.1 \times 10^{-3} \mathrm{mmols}\right)$ was added, and the suspension was subjected to sonication for another three hours. The NMR analysis of the resulting solution indicated that naphthalene was released as a consequence of the replacement of naphthalene by pyrene inside the scavenger (Figure 8). 
a)
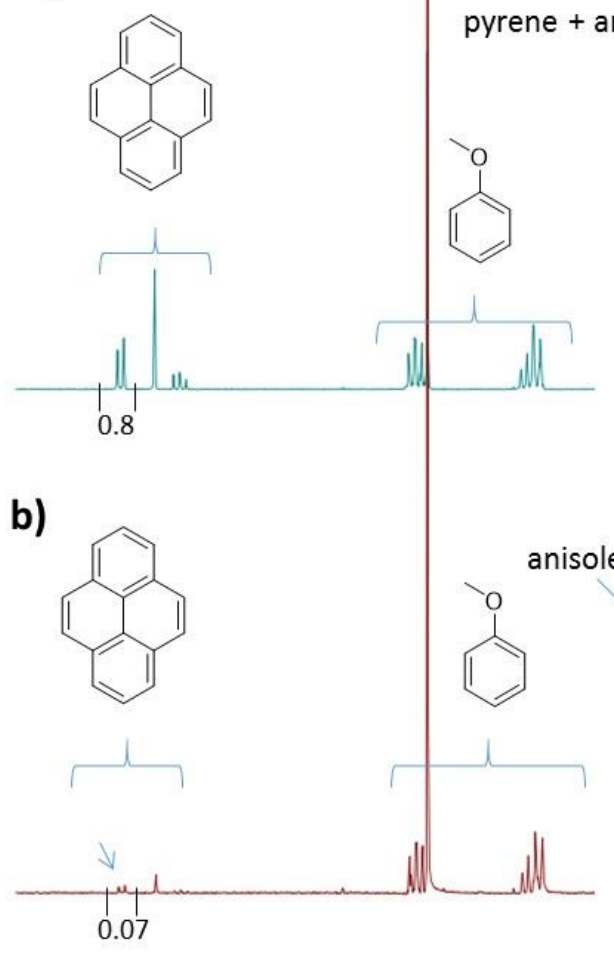

anisole

pyrene + anisole
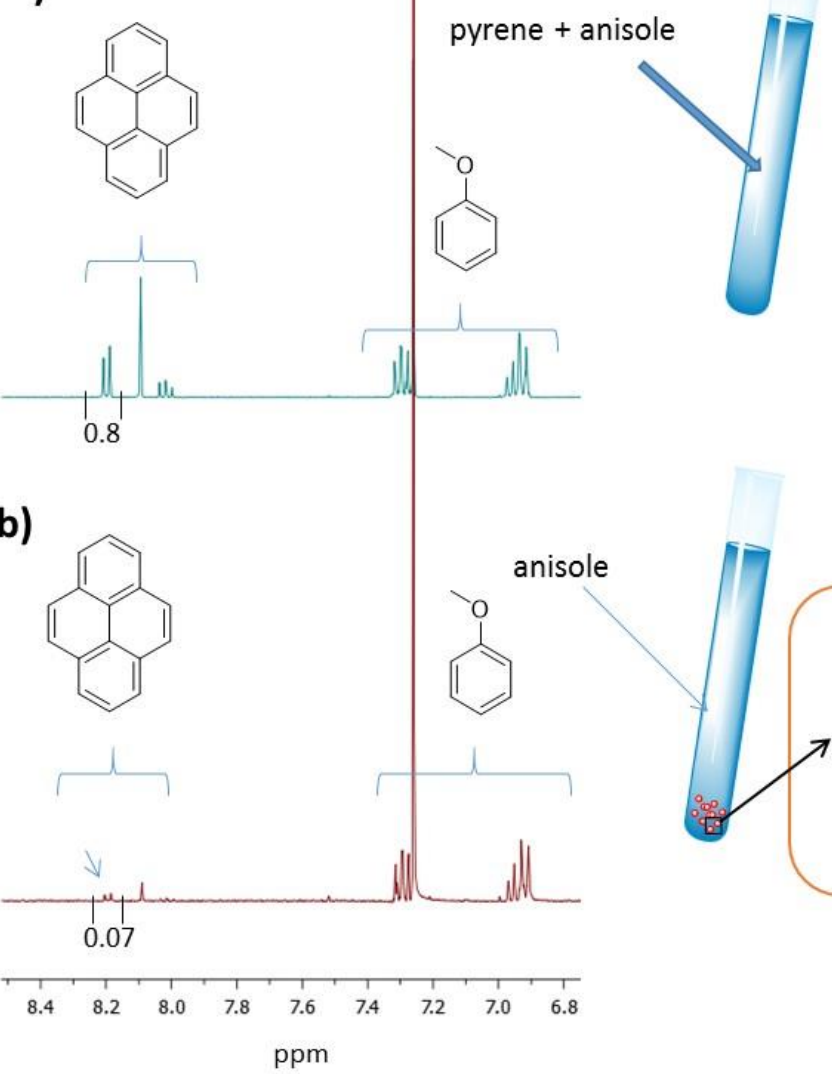

$[3]\left(\mathrm{BF}_{4}\right)_{4} \subset$ pyrene

Figure 7. Selected region of the ${ }^{1} \mathrm{H}$ NMR spectra $\left(\mathrm{CDCl}_{3}, 400 \mathrm{MHz}\right)$ of the samples prepared for the analysis of the scavenging properties of [3] $\left(\mathrm{BF}_{4}\right)$. a) ${ }^{1} \mathrm{H} \mathrm{NMR}$ spectrum of the sample before addition of $[3]\left(\mathrm{BF}_{4}\right)$. b) ${ }^{1} \mathrm{H}$ NMR spectrum of the sample after addition of $[3]\left(\mathrm{BF}_{4}\right)$ and after $3 \mathrm{~h}$ of sonication. The numbers below both spectra indicate the integrals of the reference signals of pyrene. The flux diagram indicates the experimental procedure. 


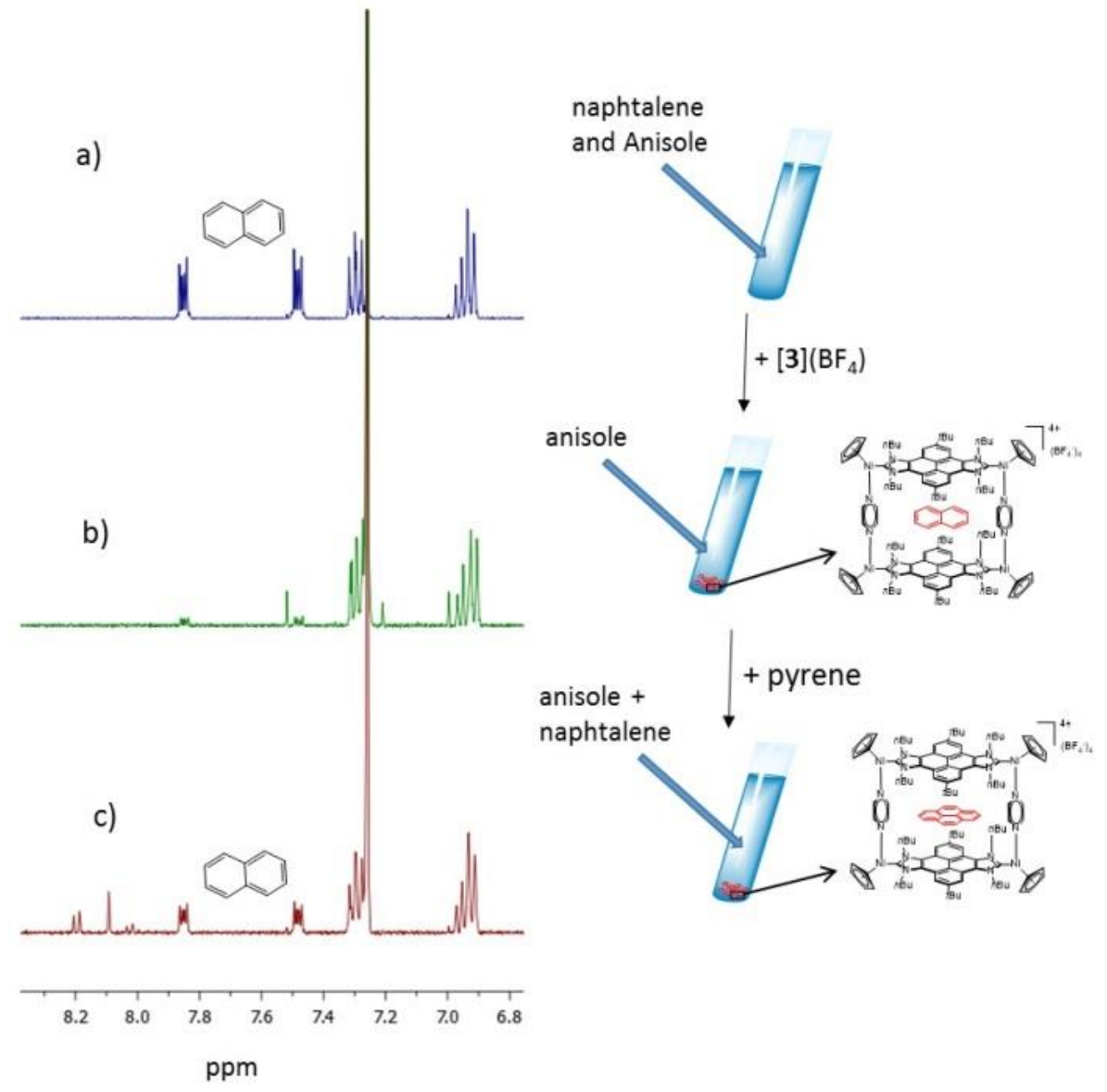

Figure 8. Competitive experiment of extraction of naphthalene and pyrene. a) ${ }^{1} \mathrm{H}$ NMR spectrum of the sample containing naphthalene before addition of $[3]\left(\mathrm{BF}_{4}\right)$. b) ${ }^{1} \mathrm{H} \mathrm{NMR}$ spectrum of the sample after addition of $[3]\left(\mathrm{BF}_{4}\right)$ and after $3 \mathrm{~h}$ of sonication. c) ${ }^{1} \mathrm{H}$ NMR spectrum of the sample after addition of pyrene and after $3 \mathrm{~h}$ of sonication. All experiments at room temperature. The sequence of images show how [3] $\left(\mathrm{BF}_{4}\right)$ scavenges naphthalene from the solution, and then how pyrene replaces naphthalene from the inclusion complex formed.

This competing experiment indicates that, in accordance with the affinity studies performed by ${ }^{1} \mathrm{H}$ NMR titrations, $[3]\left(\mathrm{BF}_{4}\right)_{4}$ shows higher affinity by pyrene also under these experimental conditions. 


\section{Conclusions}

In summary, we prepared two new nickel-cornered supramolecular coordination rectangles using a pyrene-bis-NHC ligand. The dimension of one of the sides of the rectangle was modulated by using pyrazine or $4,4^{\prime}-$ bipyridine. The two rectangles were used as receptors for the recognition of seven, potentially harmful, polycyclic aromatic hydrocarbons, where the rectangle with pyrazine formed 1:1 stoichiometric inclusion complexes, and the one with bipyridine was capable to host up to two guest molecules. The binding constants were determined by means of ${ }^{1} \mathrm{H}$ NMR titration in acetone- $d^{6}$, and higher affinities were found for the smaller PAHs, with the highest binding constants given by the inclusion complexes with pyrene and triphenylene, probably as consequence of their best dimensional matching. A good fit between the size of the PAH and the binding constant could be established by correlating the number of electrons of the guest with their association constants.

An important achievement of our work is that we were able to use both rectangles as effective PAH scavengers in heptane. The PAH is trapped inside the receptor, and its disappearance from the solution can be detected by simply irradiating the solution with a UV lamp (in the case of pyrene), and quantified by ${ }^{1} \mathrm{H}$ NMR spectroscopy. Considering the harmful effects of many of the smaller PAHs on the environment, we believe that these findings may have important implications for providing effective ways for the extraction of PAHs from apolar organic solvents. The introduction of metal centers in the design of molecular receptors may provide some benefits compared to the use of the more widely used organic-based receptors, because coordination chemistry often provides predictable and 
well-defined structures for facilitating tailor-designed metallacycles for the dimensional matching of PAHs. In our case, the introduction of nickel in the structure of the receptor introduces further benefits, first because this metal is inexpensive compared to the most widely used metal cages that use noble transition metals, and second because nickel centers in organometallic complexes often behave as a reversible redox centers, thus the affinity properties of the molecule may be potentially modulated electrochemically. This, together with the existing number of rigid di- and tri-NHC ligands that now can be found in the literature- which should enlarge the number of rectangles with a variety of shapes and sizes- opens a vast research field that hopefully inspires the work of future researchers in the area of metal-based PAH-receptors and scavengers.

\section{Acknowledgements}

We gratefully acknowledge financial support from MEC of Spain (CTQ2014-51999-P) and the Universitat Jaume I (P11B2014-02). We are grateful to the Serveis Centrals d'Instrumentació Científica (SCIC) of the Universitat Jaume I for providing with spectroscopic facilities. We would also like to thank the Generalitat Valenciana for a fellowship (S-R.-B.).

Keywords: Host-guest chemistry • supramolecular coordination complexes • polycyclic aromatic hydrocarbons $\bullet$ nickel $\bullet$ scavenger 


\section{References}

1. Smulders, M.M.J., et al., Building on architectural principles for three-dimensional metallosupramolecular construction. Chemical Society Reviews, 2013. 42(4): p. 1728-1754.

2. Constable, E.C., Expanded ligands - An assembly principle for supramolecular chemistry. Coordination Chemistry Reviews, 2008. 252(8-9): p. 842-855.

3. Nitschke, J.R., Construction, substitution, and sorting of metalloorganic structures via subcomponent self-assembly. Accounts of Chemical Research, 2007. 40(2): p. 103-112.

4. Steel, P.J., Ligand design in multimetallic architectures: Six lessons learned. Accounts of Chemical Research, 2005. 38(4): p. 243-250.

5. Wurthner, F., C.C. You, and C.R. Saha-Moller, Metallosupramolecular squares: from structure to function. Chemical Society Reviews, 2004. 33(3): p. 133-146.

6. Ballester, P., M. Fujita, and J. Rebek, Jr., Molecular containers. Chemical Society Reviews, 2015. 44(2): p. 392-393.

7. Frischmann, P.D. and M.J. MacLachlan, Metallocavitands: an emerging class of functional multimetallic host molecules. Chemical Society Reviews, 2013. 42(3): p. 871-890.

8. Han, M., D.M. Engelhard, and G.H. Clever, Self-assembled coordination cages based on banana-shaped ligands. Chemical Society Reviews, 2014. 43(6): p. 1848-1860.

9. Otte, M., Size-Selective Molecular Flasks. Acs Catalysis, 2016. 6(10): p. 6491-6510.

10. Yoshizawa, M., J.K. Klosterman, and M. Fujita, Functional Molecular Flasks: New Properties and Reactions within Discrete, Self-Assembled Hosts. Angewandte Chemie-International Edition, 2009. 48(19): p. 3418-3438.

11. Brown, C.J., et al., Supramolecular Catalysis in Metal-Ligand Cluster Hosts. Chemical Reviews, 2015. 115(9): p. 3012-3035.

12. Leenders, S.H.A.M., et al., Transition metal catalysis in confined spaces. Chemical Society Reviews, 2015. 44: p. 433-448.

13. Dydio, P. and J.N.H. Reek, Supramolecular control of selectivity in transition-metal catalysis through substrate preorganization. 
Chemical Science, 2014. 5(6): p. 2135-2145.

14. Koblenz, T.S., J. Wassenaar, and J.N.H. Reek, Reactivity within a confined self-assembled nanospace. Chemical Society Reviews, 2008. 37(2): p. 247-262.

15. Raynal, M., et al., Supramolecular catalysis. Part 1: non-covalent interactions as a tool for building and modifying homogeneous catalysts. Chemical Society Reviews, 2014. 43(5): p. 1660-1733.

16. Dong, S., et al., Supramolecular Polymers Constructed from Macrocycle-Based Host-Guest Molecular Recognition Motifs. Accounts of Chemical Research, 2014. 47(7): p. 1982-1994.

17. Ariga, K., et al., Molecular recognition: from solution science to nano/materials technology. Chemical Society Reviews, 2012. 41(17): p. 5800-5835.

18. Chen, B., S. Xiang, and G. Qian, Metal-Organic Frameworks with Functional Pores for Recognition of Small Molecules. Accounts of Chemical Research, 2010. 43(8): p. 1115-1124.

19. Galan, A. and P. Ballester, Stabilization of reactive species by supramolecular encapsulation. Chemical Society Reviews, 2016. 45(6): p. 1720-1737.

20. Schmidt, A., et al., Evaluation of New Palladium Cages as Potential Delivery Systems for the Anticancer Drug Cisplatin. Chemistry-a European Journal, 2016. 22(7): p. 2253-2256.

21. Zheng, Y.-R., et al., Encapsulation of Pt(IV) prodrugs within a Pt(II) cage for drug delivery. Chemical Science, 2015. 6(2): p. 1189-1193.

22. Therrien, B., Drug Delivery by Water-Soluble Organometallic Cages, in Chemistry of Nanocontainers, M. Albrecht and F.E. Hahn, Editors. 2012. p. 35-55.

23. Schmitt, F., et al., Organometallic Cages as Vehicles for Intracellular Release of Photosensitizers. Journal of the American Chemical Society, 2012. 134(2): p. 754-757.

24. Barry, N.P.E., et al., Excellent Correlation between Drug Release and Portal Size in Metalla-Cage Drug-Delivery Systems. Chemistrya European Journal, 2011. 17(35): p. 9669-9677.

25. Zava, O., et al., Evidence for Drug Release from a Metalla-Cage Delivery Vector Following Cellular Internalisation. Chemistry-a 
European Journal, 2010. 16(5): p. 1428-1431.

26. Therrien, B., et al., The "Complex-in-a-Complex" cations (acac)(2)M subset of RU6(p-iPrC(6)H(4)Me)(6)(tpt)(2)(dhbq)(3) (6+): A Trojan horse for cancer cells. Angewandte Chemie-International Edition, 2008. 47(20): p. 3773-3776.

27. Jones, C.J., Transition metals as structural components in the construction of molecular containers. Chemical Society Reviews, 1998. 27(4): p. 289-299.

28. Han, Y.-F., H. Li, and G.-X. Jin, Host-guest chemistry with bi- and tetra-nuclear macrocyclic metallasupramolecules. Chemical Communications, 2010. 46(37): p. 6879-6890.

29. Cook, T.R. and P.J. Stang, Recent Developments in the Preparation and Chemistry of Metallacycles and Metallacages via Coordination. Chemical Reviews, 2015. 115(15): p. 7001-7045.

30. Cook, T.R., Y.-R. Zheng, and P.J. Stang, Metal-Organic Frameworks and Self-Assembled Supramolecular Coordination Complexes: Comparing and Contrasting the Design, Synthesis, and Functionality of Metal-Organic Materials. Chemical Reviews, 2013. 113(1): p. 734-777.

31. Chakrabarty, R., P.S. Mukherjee, and P.J. Stang, Supramolecular Coordination: Self-Assembly of Finite Two- and Three-Dimensional Ensembles. Chemical Reviews, 2011. 111(11): p. 6810-6918.

32. Li, S.-S., et al., Surface Confined Metallosupramolecular Architectures: Formation and Scanning Tunneling Microscopy Characterization. Accounts of Chemical Research, 2009. 42(2): p. 249-259.

33. Leininger, S., B. Olenyuk, and P.J. Stang, Self-assembly of discrete cyclic nanostructures mediated by transition metals. Chemical Reviews, 2000. 100(3): p. 853-907.

34. Poyatos, M., J.A. Mata, and E. Peris, Complexes with poly $(N$ heterocyclic carbene) ligands: structural features and catalytic applications. Chemical Reviews, 2009. 109(8): p. 3677-3707.

35. Mata, J.A., M. Poyatos, and E. Peris, Structural and catalytic properties of chelating bis- and tris- $N$-heterocyclic carbenes. Coordination Chemistry Reviews, 2007. 251(5-6): p. 841-859.

36. Hahn, F.E., et al., A Nickel(II)-Cornered Molecular Rectangle with 
Biscarbene and 4,4 '-Bipyridine Bridging Groups. Organometallics, 2008. 27(24): p. 6408-6410.

37. Radloff, C., et al., Supramolecular structures from mono and dimetalated biscarbene ligands. Dalton Transactions, 2009(35): p. 7215-7222.

38. Radloff, C., J.J. Weigand, and F.E. Hahn, A tetranuclear molecular rectangle from four gold(I) atoms linked by dicarbene and diphosphine ligands. Dalton Transactions, 2009(43): p. 9392-9394.

39. Conrady, F.M., et al., Stepwise Formation of a Molecular Square with Bridging NH,O-Substituted Dicarbene Building Blocks. Journal of the American Chemical Society, 2011. 133(30): p. 11496-11499.

40. Schmidtendorf, M., T. Pape, and F.E. Hahn, Stepwise Preparation of a Molecular Square from NR,NR- and NH,O-Substituted Dicarbene Building Blocks. Angewandte Chemie-International Edition, 2012. 51(9): p. 2195-2198.

41. Viciano, M., M. Sanau, and E. Peris, Ruthenium Janus-head complexes with a triazolediylidene ligand. structural features and catalytic applications. Organometallics, 2007. 26(24): p. 6050-6054.

42. Mejuto, C., et al., First homoleptic MIC and heteroleptic NHC-MIC coordination cages from 1,3,5-triphenylbenzene-bridged tris-MIC and tris-NHC ligands. Chemical Communications, 2015. 51(73): $\mathrm{p}$. 13914-13917.

43. Hahn, F.E., et al., Synthesis of Silver(I) and Gold(I) Complexes with Cyclic Tetra- and Hexacarbene Ligands. Chemistry-a European Journal, 2008. 14(35): p. 10900-10904.

44. Radloff, C., et al., Metal-Dependent Coordination Modes Displayed by Macrocyclic Polycarbene Ligands. Chemistry-a European Journal, 2010. 16(44): p. 13077-13081.

45. Rit, A., T. Pape, and F.E. Hahn, Self-Assembly of Molecular Cylinders from Polycarbene Ligands and Ag-I or Au-I. Journal of the American Chemical Society, 2010. 132(13): p. 4572-4573.

46. Rit, A., et al., Supramolecular Structures from Polycarbene Ligands and Transition Metal Ions. Organometallics, 2011.30(2): p. 334-347.

47. Wang, D.H., et al., A new chiral N-heterocyclic carbene silver(I) cylinder: synthesis, crystal structure and catalytic properties. Chemical Communications, 2010. 46(26): p. 4728-4730. 
48. Segarra, C., et al., Hexanuclear cylinder-shaped assemblies of silver and gold from benzene-hexa-N-heterocyclic carbenes. Organometallics, 2014. 33(19): p. 5077-5080.

49. Sinha, N., et al., Synthesis of Nanometer-Sized Cylinder-Like Structures from a 1,3,5-Triphenylbenzene-Bridged Tris-NHC Ligand and Ag-I, Au-I, and Cu-I. Organometallics, 2014. 33(23): p. 68986904.

50. Guerret, O., et al., 1,2,4-triazole-3,5-diylidene: A building block for organometallic polymer synthesis. Journal of the American Chemical Society, 1997. 119(28): p. 6668-6669.

51. Karimi, B. and P.F. Akhavan, A novel water-soluble NHC-Pd polymer: an efficient and recyclable catalyst for the Suzuki coupling of aryl chlorides in water at room temperature. Chemical Communications, 2011. 47(27): p. 7686-7688.

52. Karimi, B. and P.F. Akhavan, A Study on Applications of $\mathrm{N}$ Substituted Main-Chain NHC-Palladium Polymers as Recyclable Self-Supported Catalysts for the Suzuki-Miyaura Coupling of Aryl Chlorides in Water. Inorganic Chemistry, 2011. 50(13): p. 60636072 .

53. Karimi, B. and P.F. Akhavan, Main-chain NHC-palladium polymer as a recyclable self-supported catalyst in the Suzuki-Miyaura coupling of aryl chlorides in water. Chemical Communications, 2009(25): p. 3750-3752.

54. Boydston, A.J. and C.W. Bielawski, Bis(imidazolylidene)s as modular building blocks for monomeric and macromolecular organometallic materials. Dalton Transactions, 2006(34): p. 40734077.

55. Mercs, L., A. Neels, and M. Albrecht, Probing the potential of $N$ heterocyclic carbenes in molecular electronics: redox-active metal centers interlinked by a rigid ditopic carbene ligand. Dalton Transactions, 2008(41): p. 5570-5576.

56. Mercs, L., et al., Main-chain organometallic polymers comprising redox-active iron(II) centers connected by ditopic $N$-heterocyclic carbenes. Dalton Transactions, 2009(35): p. 7168-7178.

57. Zhang, C., et al., Main-Chain Organometallic Microporous Polymers Based on Triptycene: Synthesis and Catalytic Application in the Suzuki-Miyaura Coupling Reaction. Chemistry-a European Journal, 
2013. 19(16): p. 5004-5008.

58. Choi, J., et al., Organometallic Hollow Spheres Bearing Bis $(N$ Heterocyclic Carbene)-Palladium Species: Catalytic Application in Three-Component Strecker Reactions. Angewandte ChemieInternational Edition, 2010. 49(42): p. 7718-7722.

59. Gonell, S., M. Poyatos, and E. Peris, Main-Chain Organometallic Microporous Polymers Bearing Triphenylene-Tris(N-HeterocyclicCarbene)-Gold Species. Catalytic Properties. Chemistry-a European Journal, 2014. 20: p. 5746-5751.

60. Boydston, A.J., K.A. Williams, and C.W. Bielawski, A modular approach to main-chain organometallic polymers. Journal of the American Chemical Society, 2005. 127(36): p. 12496-12497.

61. Schmidtendorf, M., T. Pape, and F.E. Hahn, Molecular rectangles from platinum(II) and bridging dicarbene, diisocyanide and 4,4'bipyridine ligands. Dalton Transactions, 2013. 42(45): p. 1612816141.

62. Schmidtendorf, M., C.S. to Brinke, and F.E. Hahn, Benzodicarbenebridged dinuclear complexes as building blocks for metalosupramolecular architectures. Journal of Organometallic Chemistry, 2014. 751: p. 620-627.

63. Sinha, A., et al., Single-Step Synthesis of Organometallic Molecular Squares from

NR,NR',NR',NR',' -Substituted Benzobiscarbenes. Chemistry-a European Journal, 2016: p. DOI: 10.1002/chem.201604996.

64. Gonell, S., M. Poyatos, and E. Peris, Pyrene-Based Bisazolium Salts: From Luminescence Properties to Janus-Type Bis-N-Heterocyclic Carbenes. Chemistry-a European Journal, 2014. 20(31): p. 97169724.

65. Prades, A., E. Peris, and M. Alcarazo, Pyracenebis(imidazolylidene): a new Janus-type biscarbene and its coordination to rhodium and iridium. Organometallics, 2012. 31(12): p. 4623-4626.

66. Valdes, H., M. Poyatos, and E. Peris, A Nanosized Janus Bis-Nheterocyclic Carbene Ligand Based on a Quinoxalinophenanthrophenazine Core, and Its Coordination to Iridium. Organometallics, 2015. 34(9): p. 1725-1729.

67. Peris, E., Polyaromatic N-heterocyclic carbene ligands and pi- 
stacking. Catalytic consequences. Chemical Communications, 2016. 52(34): p. 5777-5787.

68. Keyte, I.J., R.M. Harrison, and G. Lammel, Chemical reactivity and long-range transport potential of polycyclic aromatic hydrocarbons a review. Chemical Society Reviews, 2013. 42(24): p. 9333-9391.

69. Haritash, A.K. and C.P. Kaushik, Biodegradation aspects of Polycyclic Aromatic Hydrocarbons (PAHs): A review. Journal of Hazardous Materials, 2009. 169(1-3): p. 1-15.

70. Lemieux, C.L., et al., Mutagenic hazards of complex polycyclic aromatic hydrocarbon mixtures in contaminated soil. Environmental Toxicology and Chemistry, 2008. 27(4): p. 978-990.

71. Srogi, K., Monitoring of environmental exposure to polycyclic aromatic hydrocarbons: a review. Environmental Chemistry Letters, 2007. 5(4): p. 169-195.

72. Govindarajan, R., R. Nagarajaprakash, and B. Manimaran, Synthesis, Structural Characterization, and Host-Guest Studies of Aminoquinonato-Bridged Re(I) Supramolecular Rectangles. Inorganic Chemistry, 2015. 54(22): p. 10686-10694.

73. Lopez-Vidal, E.M., et al., Metallacycle-Catalyzed SNAr Reaction in Water: Supramolecular Inhibition by Means of Host-Guest Complexation. Journal of Organic Chemistry, 2014. 79(3): p. 12651270.

74. Alvarino, C., et al., Dimensional Matching of Polycyclic Aromatics with Rectangular Metallacycles: Insertion Modes Determined by $\mathrm{C}$ $H$ center dot center dot center dot pi Interactions. Chemistry-a European Journal, 2013. 19(45): p. 15329-15335.

75. Blanco, V., et al., Complexation and Extraction of PAHs to the Aqueous Phase with a Dinuclear Pt-II Diazapyrenium-Based Metallacycle. Chemistry-a European Journal, 2010. 16(41): p. 1237312380.

76. Peinador, C., et al., Complexation of Pyrene in Aqueous Solution with a Self-Assembled Palladium Metallocycle. Organic Letters, 2010. 12(7): p. 1380-1383.

77. Yuan, M.H., et al., Synthesis and Electrochemical Behavior of a Zwitterion-Bridged Metalla-Cage. Organometallics, 2014. 33(18): p. 5043-5045. 
78. Garcia, M.D., et al., Complexation of aromatic compounds with selfassembled Pd-II and Pt-II metallacycles. Inorganica Chimica Acta, 2014. 417: p. 27-37.

79. Kishi, N., et al., Wide-Ranging Host Capability of a Pd-II-Linked M2L4 Molecular Capsule with an Anthracene Shell. Chemistry-a European Journal, 2013. 19(20): p. 6313-6320.

80. Ibañez, S., et al., Fluorescent Pyrene-Based Bis-azole Compounds: Synthesis and Photophysical Analysis. Chemistry-a European Journal, 2015. 21(29): p. 10566-10575.

81. Funari, C.S., et al., Acetone as a greener alternative to acetonitrile in liquid chromatographic fingerprinting. Journal of Separation Science, 2015. 38(9): p. 1458-1465.

82. Keppel, T.R., M.E. Jacques, and D.D. Weis, The use of acetone as a substitute for acetonitrile in analysis of peptides by liquid chromatography/electrospray ionization mass spectrometry. Rapid Communications in Mass Spectrometry, 2010. 24(1): p. 6-10.

83. Dale, E.J., et al., ExCage. Journal of the American Chemical Society, 2014. 136(30): p. 10669-10682.

84. Thordarson, P., Determining association constants from titration experiments in supramolecular chemistry. Chemical Society Reviews, 2011. 40(3): p. 1305-1323.

85. Lowe, A.J., F.M. Pfeffer, and P. Thordarson, Determining binding constants from H-1 NMR titration data using global and local methods: a case study using $n$ polynorbornane-based anion hosts. Supramolecular Chemistry, 2012. 24(8): p. 585-594.

86. Connors, K.A., A. Paulson, and D. Toledovelasquez, COMPLEXING OF ALPHA-CYCLODEXTRIN WITH SYM-4,4'-DISUBSTITUTED BIPHENYLS. Journal of Organic Chemistry, 1988. 53(9): p. 20232026.

87. Perlmutterhayman, B., COOPERATIVE BINDING TO MACROMOLECULES - A FORMAL APPROACH. Accounts of Chemical Research, 1986. 19(3): p. 90-96.

88. Hunter, C.A. and H.L. Anderson, What is Cooperativity? Angewandte Chemie-International Edition, 2009. 48(41): p. 74887499.

89. Mecozzi, S. and J. Rebek, The 55\% solution: A formula for 
molecular recognition in the liquid state. Chemistry-a European Journal, 1998. 4(6): p. 1016-1022.

90. Barnes, J.C., et al., ExBox: A Polycyclic Aromatic Hydrocarbon Scavenger. Journal of the American Chemical Society, 2013. 135(1): p. 183-192.

91. Ibáñez, S., et al., Fluorescent Pyrene-Based Bis-azole Compounds: Synthesis and Photophysical Analysis. Chemistry European Journal, 2015. 21(29): p. 10566-10575.

92. Gonell, S., M. Poyatos, and E. Peris, Pyrene-Based Bisazolium Salts: From Luminescence Properties to Janus-Type Bis-N-Heterocyclic Carbenes. Chemistry European Journal, 2014. 20(31): p. 9716-9724. 


\title{
(-) A Shape-Adaptable Organometallic Supramolecular Coordination Cage for the Encapsulation of Fullerenes
}

\author{
Víctor Martínez-Agramunt, ${ }^{[\mathrm{a}]}$ Dmitry G. Gusev, ${ }^{[\mathrm{b}]}$ and Eduardo Peris ${ }^{*[\mathrm{a}]}$
}

Abstract: The development of three-dimensional supramolecular coordination complexes (SCCs), with cavities suitable for guest binding, is of great interest because these materials are useful in a large number of applications. Herein, a nickel-conjoined organometallic molecular prism is described, which has been fully characterized. The X-ray diffraction structure of the molecule reveals that the cage possesses an internal cavity with a volume of $1028 \AA^{3}$, thus suitable for the encapsulation of large 3D-molecules, such as ful- lerenes. This cage shows highly selective complexation of $C_{70}$ over $C_{60}$, thus being potentially useful for fullerene separation and purification. The combined experimental and computational studies suggest that the complexation process is largely entropically-driven, and DFT calculations suggest that the cage is flexible and can adapt the size and the shape of the cavity to maximize the face-to-face interaction with the fullerenes.

\section{Introduction}

The rich coordination chemistry of transition metals and the availability of a large number of organic ligands have provided access to many two- and three-dimensional metallosupramolecular architectures with applications in catalysis, ${ }^{[1]}$ molecular recognition, ${ }^{[2]}$ for stabilizing highly reactive species, ${ }^{[3]}$ and as drug delivery/release vectors. ${ }^{[4]}$ Of particular interest are supramolecular coordination complexes (SCCs) with well-defined cavities suitable for guest binding ${ }^{[5]}$ the host-guest chemistry arguably being the most important feature of SCCS from which most applications can be derived. In particular, the selective encapsulation of large aromatic compounds, such as fullerenes ${ }^{[6]}$ and polycyclic aromatic hydrocarbons $(\mathrm{PAHs})^{[7]}$ is of increasing interest, since it may provide practical solutions for the purification of molecules which otherwise would be very difficult to separate due to their similar physicochemical properties.

While most of the known metallosupramolecular structures are Werner-type coordination complexes, in the last five years a number of organometallic supramolecular architectures have

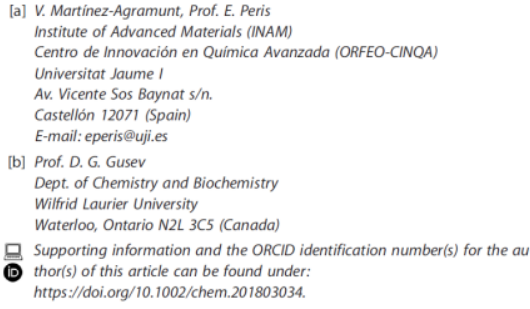

emerged, most of them based on the use of $\mathrm{N}$-heterocyclic carbenes (NHCs). ${ }^{[8]}$ However, due to the scarcity of ligands of the appropriate sizes, most known organometallic metallosupramolecules are too small to host organic molecules, and this explains why organometallic host-guest chemistry is rare. Advancing organometallic host-guest chemistry is possible through the development of poly-NHC ligands that mimic the supramolecular architectures facilitated by Werner-type ligands, thus allowing the preparation of arguably more stable organometallic assemblies supported by the strong NHC-M bonds. By designing a series of NHC ligands decorated with rigid polyaromatic functionalities, ${ }^{[9]}$ we recently gained access to a number of organometallic supramolecular complexes, which we used for the recognition of different organic molecules $^{[6,7,7,10]}$ and metal cations. ${ }^{[1]]}$ In one of our approaches, we formed two nickel-cornered molecular rectangles using a pyrene-bis-imidazolylidene ligand ( $\boldsymbol{B}$ and $\mathbf{C}$, Scheme 1). ${ }^{[7]}$ The two-dimensional complexes $\mathbf{B}$ and $\mathbf{C}$ resemble the previously reported molecular rectangle $\mathbf{A}$, described by $\mathrm{Hahn}$ and $\mathrm{co}-$ workers in 2008. ${ }^{[12]}$ However, whereas A was unsuitable even for the recognition of the smaller PAHs, due to the relatively short separation provided by the benzoimidazolylidene ligand $(10.4 \AA), B$ and $C$ served as effective receptors and scavengers of a range of polyaromatic molecules, due to the longer separation provided by the pyrene-bisimidazolylidene ligand ( $13 \AA$ ), and due to the effective steric and electronic complementarity. We recently became interested in obtaining a three-dimensional molecular cage based on the same organometallic supramolecular motif as the one used in B and C. We envisaged that, if $\mathbf{B}$ and $\mathbf{C}$ were able to effectively encapsulate two-dimensional organic molecules by multiple synergistic aromatic interactions, a related three-dimensional cage should be able to recognize 3D organic molecules, such as fullerenes. Additionally, we hypothesized that a relatively rigid organometallic 
Chem. Eur. J. 24 (2018) 14802-14807

\title{
A shape-adaptable organometallic supramolecular coordination cage for the encapsulation of fullerenes
}

Víctor Martínez-Agramunt, ${ }^{[a]}$ Dmitry G. Gusev ${ }^{[\mathrm{b}]}$ and Eduardo Peris ${ }^{*[a]}$

${ }^{a}$ Institute of Advanced Materials (INAM). Centro de Innovación en Química Avanzada (ORFEO-CINQA). Av. Vicente Sos Baynat s/n. Universitat Jaume I, 12071 Castellón. Spain.

${ }^{\mathrm{b}}$ Department of Chemistry and Biochemistry, Wilfrid Laurier University, N2L 3C5, Waterloo, Ontario, Canada.

\begin{abstract}
The development of three dimensional supramolecular coordination complexes (SCCs) with cavities suitable for guest binding is of great interest because these materials are useful in a large number of applications. Herein, we describe a nickel-conjoined organometallic molecular prism, which has been fully characterized. The X-ray diffraction structure of the molecule reveals that the cage possesses an internal cavity with a volume of $1028 \AA^{3}$, thus suitable for the encapsulation of large 3D-molecules, such as fullerenes.
\end{abstract}


This cage shows highly selective complexation of $\mathrm{C}_{70}$ over $\mathrm{C}_{60}$, thus being potentially useful for fullerene separation and purification. The combined experimental and computational studies suggest that the complexation process is largely entropically-driven, and DFT calculations suggest that the cage is flexible and can adapt the size and the shape of the cavity to maximize the face-to-face interaction with the fullerenes.

\section{Introduction}

The rich coordination chemistry of transition metals and the availability of a large number of organic ligands have provided access to many two- and three-dimensional metallosupramolecular architectures with applications in catalysis, ${ }^{[1-7]}$ molecular recognition, ${ }^{[8-10]}$ for stabilizing highly reactive species, ${ }^{[11]}$ and as drug delivery/release vectors. ${ }^{[12-19]}$ Of particular interest are supramolecular coordination complexes (SCCs) with well-defined cavities suitable for guest binding, ${ }^{[20-25]}$ the host-guest chemistry arguably being the most important feature of SCCs, from which most applications can be derived. In particular, the selective encapsulation of large aromatic compounds, such as fullerenes ${ }^{[26-34]}$ and polycyclic aromatic hydrocarbons $(\mathrm{PAHs})^{[35-43]}$ is of increasing interest since it may provide practical solutions for the purification of molecules which otherwise would be very difficult to separate due to their similar physicochemical properties.

While most of the known metallosupramolecular structures are Werner-type coordination complexes, in the last five years a number of organometallic supramolecular architectures have emerged, most of them based on the use of N-heterocyclic carbenes (NHCs). ${ }^{[44]}$ However, due to the scarcity of ligands of the appropriate sizes, most known organometallic 
metallosupramolecules are too small to host organic molecules, and this explains why organometallic host-guest chemistry is rare. Advancing organometallic host-guest chemistry is possible through the development of poly-NHC ligands that mimic the supramolecular architectures facilitated by Werner-type ligands, thus allowing the preparation of arguably more stable organometallic assemblies supported by the strong NHC-M bonds. By designing a series of NHC ligands decorated with rigid polyaromatic functionalities, ${ }^{[45-50]}$ we recently gained access to a number of organometallic supramolecular complexes, which we used for the recognition of different organic molecules ${ }^{[31,43,51,52]}$ and metal cations. ${ }^{[53]}$ In one of our approaches, we formed two nickel-cornered molecular rectangles using a pyrene-bisimidazolylidene ligand (B and $\mathbf{C}$, Scheme 1). ${ }^{[43]}$

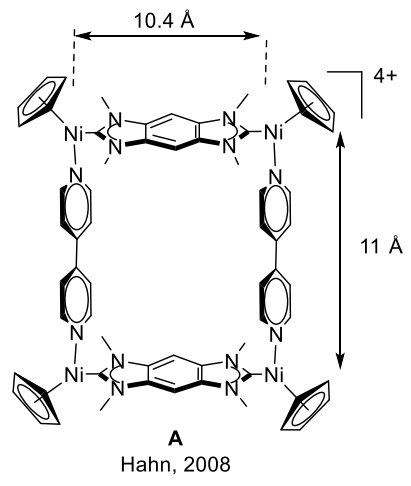

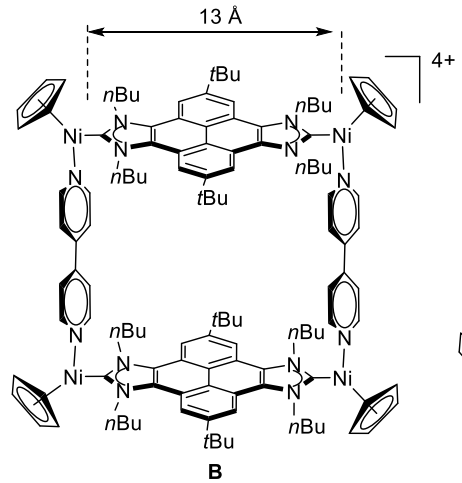

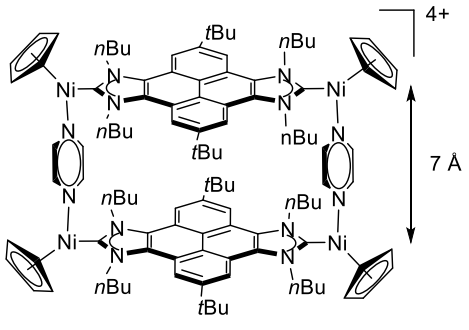

C

Scheme 1. Nickel-conjoined molecular rectangles

The two-dimensional complexes $\mathbf{B}$ and $\mathbf{C}$ resemble the previously reported molecular rectangle $\mathbf{A}$, described by Hahn and co-workers in 2008. ${ }^{[54]}$ However, while $\mathbf{A}$ was unsuitable even for the recognition of the smaller PAHs due to the relatively short separation provided by the benzoimidazolylidene ligand (10.4 $\mathrm{A}$ ), $\mathbf{B}$ and $\mathbf{C}$ served as effective receptors 
and scavengers of a range of polyaromatic molecules, due to the longer separation provided by the pyrene-bisimidazolylidene ligand ( $13 \AA$ ), and due to the effective steric and electronic complementarity. We recently became interested in obtaining a three-dimensional molecular cage based on the same organometallic supramolecular motif as the one used in $\mathbf{B}$ and $\mathbf{C}$. We envisaged that, if $\mathbf{B}$ and $\mathbf{C}$ were able to effectively encapsulate twodimensional organic molecules by multiple synergistic aromatic interactions, a related three-dimensional cage should be able to recognize 3-D organic molecules, such as fullerenes. Additionally, we hypothesized that a relatively rigid organometallic supramolecular cage should render size-dependent selective complexation of fullerenes. Finding systems for the selective encapsulation of fullerenes, ${ }^{[27]}$ and especially finding receptors for the selective complexation of $\mathrm{C}_{70}$ over $\mathrm{C}_{60},{ }^{[55-57]}$ is a challenging field of research that continuous to gain interest. In this communication, we describe the preparation of a three-dimensional nickel-cornered trigonal prism constituted by pyrene-di-imidazolylidene and 1,3,5-tripyridyl-triazine (TPT) ligands. This cage shows highly selective complexation of $\mathrm{C}_{70}$ over $\mathrm{C}_{60}$.

\section{Results and Discussion}

The reaction of the bis-nickel-pyrene-di-imidazolylidene complex $\mathbf{1}$ with TPT and two equivalents of $\mathrm{AgBF}_{4}$ in dichloromethane afforded the airstable metallocage 2 as a red solid, in $60 \%$ yield after purification (Scheme 2). The hexametallic complex 2 was characterized by NMR spectroscopy, mass spectrometry and elemental analysis. The correct stoichiometry of the 
cage was confirmed by ESI-TOF-MS, which showed peaks at m/z 1161.2 and 1785.2 assigned to $\left[2-3 \mathrm{BF}_{4}\right]^{3+}$ and $\left[2-2 \mathrm{BF}_{4}\right]^{4+}$, respectively.

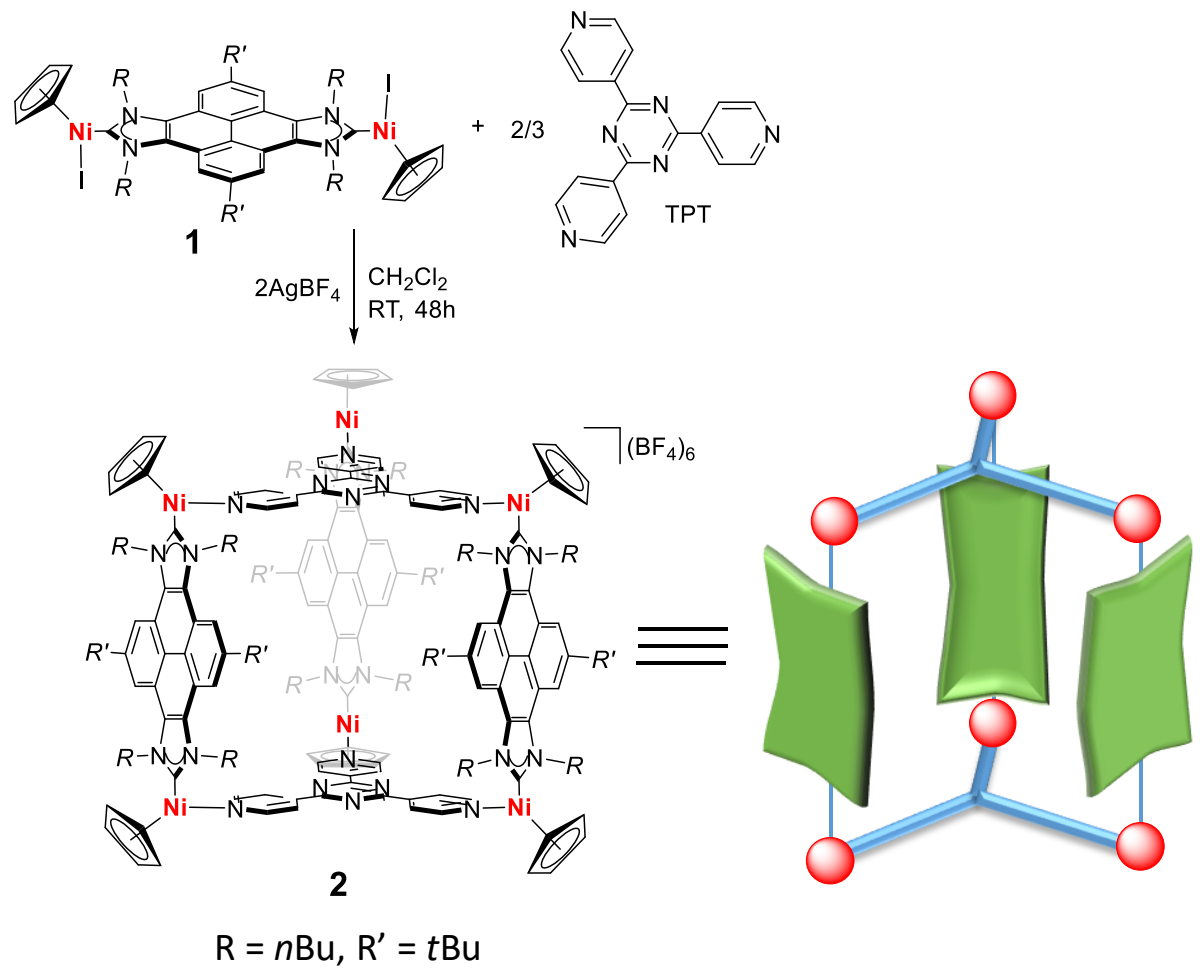

Scheme 2. Synthesis of metallocage 2

The formation of a single assembly was further confirmed by Diffusionordered NMR spectroscopy (DOSY), which revealed that all the proton signals showed the same diffusion coefficient in deuterated acetone $2.7 \times 10^{-10}$ $\mathrm{m}^{2} \mathrm{~s}^{-1}$ (see SI for details). By using the Stokes-Einstein equation, this coefficient provides an estimated hydrodynamic radius of $6.2 \AA$, in a good agreement with the expected radius of $\mathbf{2}$ based on the known size of the bisNHC and TPT ligands. The molecular structure of $\mathbf{2}$ was determined by Xray diffraction (Figure 1). The molecule contains six nickel atoms connected 
by two TPT ligands and three pyrene-di-imidazolylidenes, thus forming a trigonal prism with pseudo- $D_{3 \mathrm{~h}}$ symmetry.

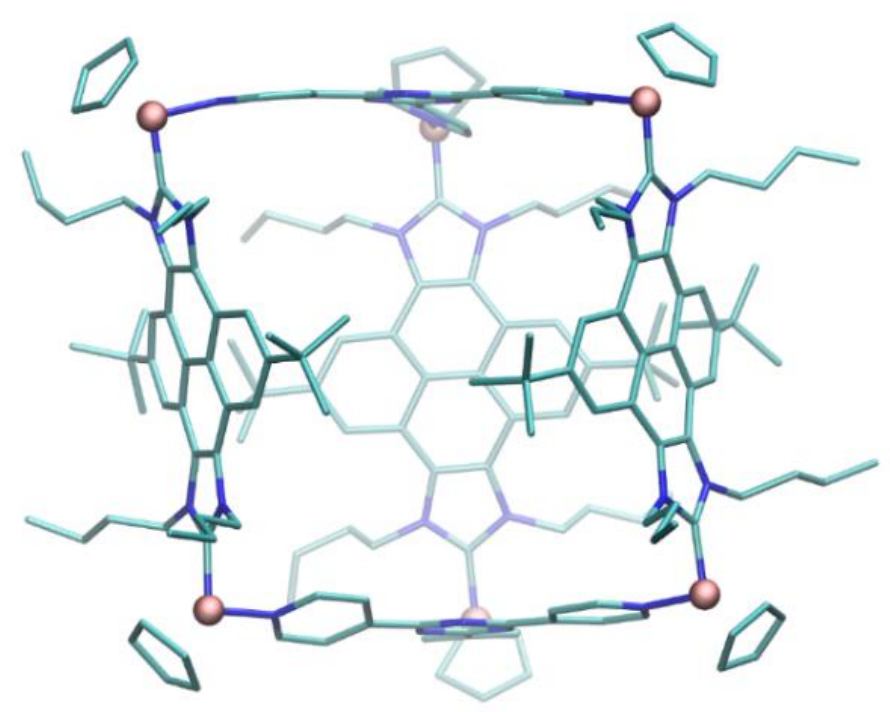

Figure 1. X-Ray molecular structure of 2. The counter-anions $\left(6 \mathrm{BF}_{4}{ }^{-}\right)$and solvent (dichloroethane) are omitted for clarity.

The central pyrene fragments of the bis-NHC ligands are bent along the corresponding $\mathrm{Ni}-\mathrm{Ni}$ axis, resulting in a convex curvature with respect to the inner cavity of the cage. The same pyrene fragments also show a concave curvature along the axis defined by the corresponding tert-butyl groups. These two distortions make the trigonal prism look as if tied around by an imaginary belt, as reflected by the average distance between the centroid of the cage and the two central carbons of the pyrenes (6.89 $)$ ), and the average distance between the centroid of the TPT ligand and the nickel atoms (7.43 $\AA$ ). The average Ni-Ni through-space distance across the bis-NHC ligand is $12.93 \AA$, that is practically the same as the average Ni-Ni distance along the 
triangular face of the prism, $12.86 \AA$. The effective size of the central cavity $^{[58]}$ is $1028 \AA^{3}$.

Considering the size of the internal cavity of $\mathbf{2}$ and the polyaromatic nature of its surface, we envisioned that this molecule might be a good system for studying supramolecular binding of fullerenes. We first performed an experiment that involved dissolving 2 in acetone- $d_{6}$ in the presence of a suspension of $\mathrm{C}_{60}$ in an NMR tube. The product mixture was sonicated at room temperature, and changes in the sample were followed by ${ }^{1} \mathrm{H}$ NMR spectroscopy. In this experiment we took advantage of the high solubility of 2 in acetone, the solvent where $\mathrm{C}_{60}$ is practically insoluble, so that the fullerene could become NMR-observable only if captured by the metallocage. As can be seen from the spectra presented in Figure 2, we initially observed the ${ }^{1} \mathrm{H}$ NMR spectrum of the empty molecular cage 2 .

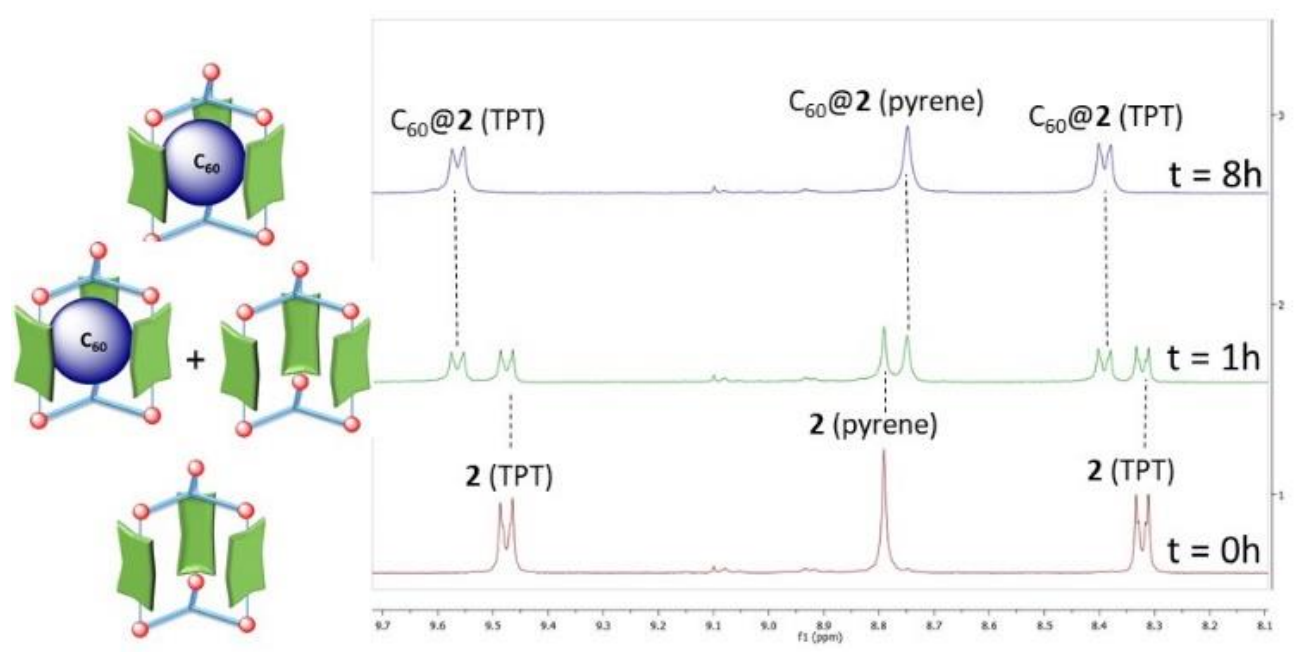

Figure 2. The aromatic region of ${ }^{1} \mathrm{H}$ NMR spectra of a mixture of 2 with $\mathrm{C}_{60}$ in acetone- $d_{6}$. The spectra were recorded immediately after mixing, and 1 and $8 \mathrm{~h}$ later). 
After $1 \mathrm{~h}$, a new species appeared in the spectrum, attributed to the formation of a host-guest complex $\mathrm{C}_{60} @ 2$. The signal due to the protons of the pyreneconnecting group of the di-NHC ligand is upfield shifted with respect to the related signal of the empty cage. In addition, the signals due to the protons of the TPT ligand are downfield shifted with respect to the corresponding resonances of $\mathbf{2}$. These observations are consistent with the fullerene being accommodated inside the cavity of $\mathbf{2}$ and interacting via $\pi$-stacking with the internal polyaromatic surface of the cage. The spectrum recorded after $8 \mathrm{~h}$ of reaction showed only the signals due to the $\mathrm{C}_{60} @ 2$ adduct, therefore indicating that the conversion was complete. A similar experiment was carried out using $\mathrm{C}_{70}$ and provided similar results, affording clear evidence of formation of a $\mathrm{C}_{70} @ 2$ complex (see ESI for details). These experiments allowed us to isolate $\mathrm{C}_{60} @ \mathbf{2}$ and $\mathrm{C}_{70} @ \mathbf{2}$, by simply filtering off the remaining insoluble fullerenes, followed by solvent evaporation. The ${ }^{13} \mathrm{C}$ NMR spectra of the isolated $\mathrm{C}_{60} @ 2$ and $\mathrm{C}_{70} @ 2$ in acetone- $d_{6}$ displayed the characteristic signals due to the carbons of the fullerenes (see ESI for full details).

For the determination of the binding constants we found that a mixture of acetone/dichlorobenzene (1:4) provided the best solubilities for both the host and the guests. By using this solvent mixture, we observed that exchange of the free and bound host signals was slow on the NMR timescale, so integration of the distinct signals of free $\mathbf{2}$ and the complexes fullerene@2 was used to calculate the equilibrium constants. This way, we obtained the binding constants of $4.7 \times 10^{3}$ and $3.5 \times 10^{4} \mathrm{M}^{-1}$, for the encapsulation of $\mathrm{C}_{60}$ and $\mathrm{C}_{70}$ at room temperature, respectively. This result indicates a preferred complexation of $\mathrm{C}_{70}$ over $\mathrm{C}_{60}$ of about one order of magnitude. The constants obtained are very large, especially considering that they were obtained using 
a mixture of solvents containing $80 \%$ dichlorobenzene, a good solvent for fullerenes for which lower association constants are often observed. ${ }^{[59]}$ By recording variable-temperature ${ }^{1} \mathrm{H}$ NMR spectra, we obtained a series of binding constants that allowed us to determine the association enthalpies and entropies from the related Van't Hoff plots (Figure 3).
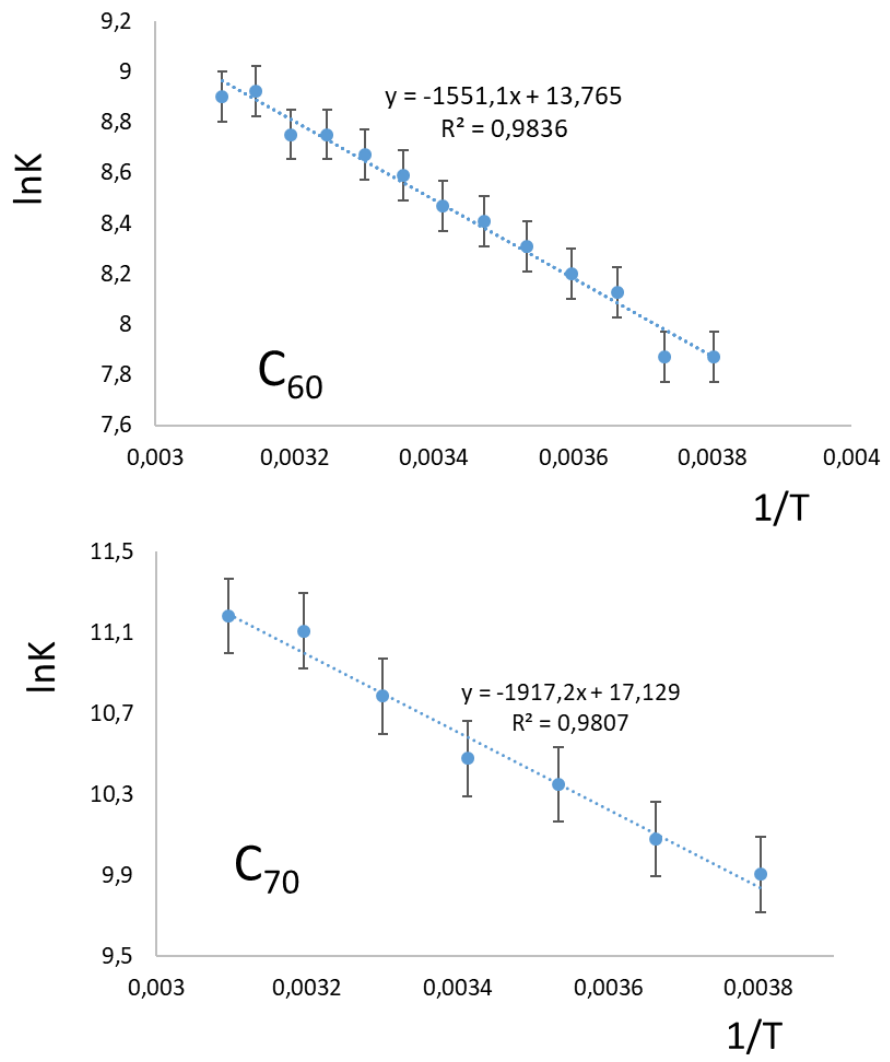

Figure 3. Plots of $\operatorname{lnK} v s .1 / \mathrm{T}$. The plots were built by using the binding constants obtained from the ${ }^{1} \mathrm{H}$ NMR spectra taken at different temperatures, from equimolar solutions $(0.3$ $\mathrm{mM}$ ) of 2 and fullerene in acetone- $d_{6}$ :dichlorobenzene- $d_{4}$ 1:4. Error bands assume uncertainties of $10 \%\left(\mathrm{C}_{60}\right)$ and $20 \%\left(\mathrm{C}_{70}\right)$ in binding constant values.

The thermodynamic values obtained for the association of $\mathrm{C}_{60}$ were $\Delta \mathrm{H}=3.1$ $\mathrm{kcal} / \mathrm{mol}$ and $\Delta \mathrm{S}=27 \mathrm{cal} / \mathrm{molK}$. For $\mathrm{C}_{70}$, the values were $\Delta \mathrm{H}=3.8 \mathrm{kcal} / \mathrm{mol}$ 
and $\Delta \mathrm{S}=34 \mathrm{cal} / \mathrm{molK}$. It is worth noting that the thermodynamic values obtained for the $\mathrm{C}_{70}$ case are affected by a higher error than those obtained for the $\mathrm{C}_{60}$ case, due to the difficulties observed for the determination of the constants at the lower temperatures, because the overlapping of the signals forced us to estimate the constants by deconvolution. With these data in hand, we concluded that the low enthalpies and relatively large entropies observed indicate that the encapsulation of fullerenes by $\mathbf{2}$ is assisted by the intrinsic entropic contribution $(-\mathrm{T} \Delta \mathrm{S})$, to afford negative free energy changes. Thus, the complexation is entropically favored by desolvation of the host and the guest. The complexation of $C_{70}$ shows a greater value of $\Delta S$ due to the larger number of solvent molecules bound to $\mathrm{C}_{70}$ relative to $\mathrm{C}_{60}$, as a consequence of the larger molecular surface of the former. The endothermicity of the associations is explained by the large solvation enthalpies of the host and guest. E.g., experimental solvation energies of 30.5 and $-35.3 \mathrm{kcal} / \mathrm{mol}$ were reported for $\mathrm{C}_{60}$ and $\mathrm{C}_{70}$ respectively, in $o$ dichlorobenzene. ${ }^{[60,61]}$

Given the greater effective affinity of the metallocage 2 for $\mathrm{C}_{70}$ over $\mathrm{C}_{60}$, we designed two competitive experiments aiming to provide practical experimental procedures for the separation of these two types of fullerenes. In the first experiment (Figure 4a), we suspended an equimolar mixture of $\mathrm{C}_{60}$ and $\mathrm{C}_{70}$ in acetone- $d_{6}$, and added one equivalent of 2 ; then the mixture was sonicated for $6 \mathrm{~h}$. The analysis of the solution by ${ }^{13} \mathrm{C}$ NMR and mass spectrometry indicated that only $\mathrm{C}_{70}$ was trapped by $\mathbf{2}$. The suspension was filtered off, and the black solid was redissolved in dichlorobenzene- $d_{4}$. The ${ }^{13} \mathrm{C}$ NMR of this sample confirmed the presence of the remaining pure $\mathrm{C}_{60}$ in this solution. In the second experiment (Figure $4 \mathrm{~b}$ ), a suspension of $\mathrm{C}_{60}$ and an equivalent amount of $\mathbf{2}$ were sonicated in acetone- $d_{6}$ until quantitative 
encapsulation of the fullerene. The presence of $\mathrm{C}_{60}$ inside the cavity of $\mathbf{2}$ was confirmed by ${ }^{13} \mathrm{C}$ NMR spectroscopy and mass spectrometry. Then, one equivalent of $\mathrm{C}_{70}$ was added to the mixture, and the suspension was sonicated for $6 \mathrm{~h}$. The analysis of the resulting solution indicated that $\mathrm{C}_{70}$ had replaced $\mathrm{C}_{60}$ in the interior of the cavity, while the analysis of the solid confirmed the release of $\mathrm{C}_{60}$.

a)

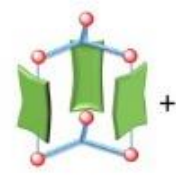

b)

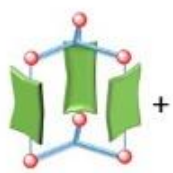

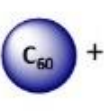

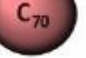
Acetone- $d_{6}, \mathrm{RT} \longrightarrow$ Ultra-Sound, $6 \mathrm{~h}$
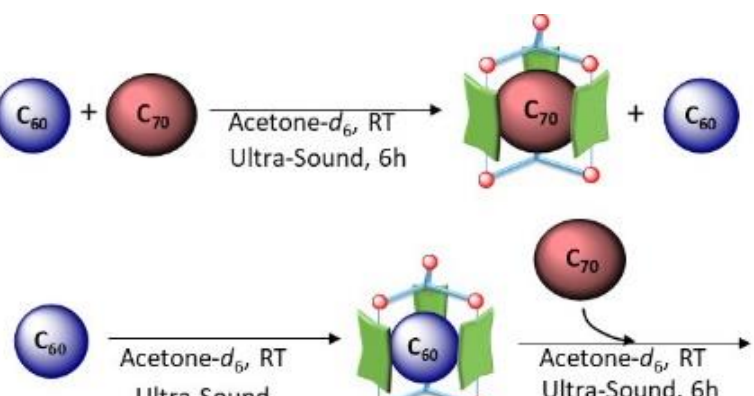

Acetone- $d_{6}$, RT Ultra-Sound

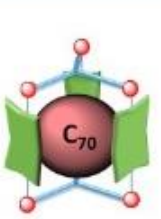

ESI-TOF-MS:

$\mathrm{m} / \mathrm{z}$ peaks at: $830.1,1059.4,1441.5$

${ }^{13} \mathrm{C}$ NMR (acetone- $d^{5}$ ): peaks at: $148.8 ; 146.4 ; 145.5 ; 143.6 ; 129.1 \mathrm{ppm}$
Characterization of products

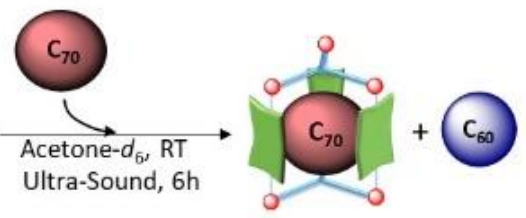

Figure 4. Schematic representation of competitive experiments, together with the characterization data of the resulting host:guest complexes formed.

These two simple experiments illustrate how the metallocage 2 can be used as a convenient molecular receptor for selective fullerene binding and release, and thus practical applications for the purification of fullerenes may be envisaged. We performed DFT (M06-L/Def2SVP in $o$-dichlorobenzene solvent continuum) and semi-empirical (PM7) studies (see SI for details) to obtain more information about the geometries and binding energies of the complexes produced by the encapsulation of $\mathrm{C}_{60}$ and $\mathrm{C}_{70}$ in 2 (Figure 5). 
According to the DFT calculations, the cage of $\mathrm{C}_{70} @ \mathbf{2}$ retains the approximate $D_{3 \mathrm{~h}}$ symmetric shape of $\mathbf{2}$, and the hexametallic prism of the calculated structure does not reveal significant structural distortions compared to the experimental structure of Figure 1. These observations are also confirmed by the effective volume of the cage of $\mathbf{C}_{70} @ 2\left(880 \AA^{3}\right)$, which is slightly smaller compared to that in the empty $\mathbf{2}$ (vide supra).
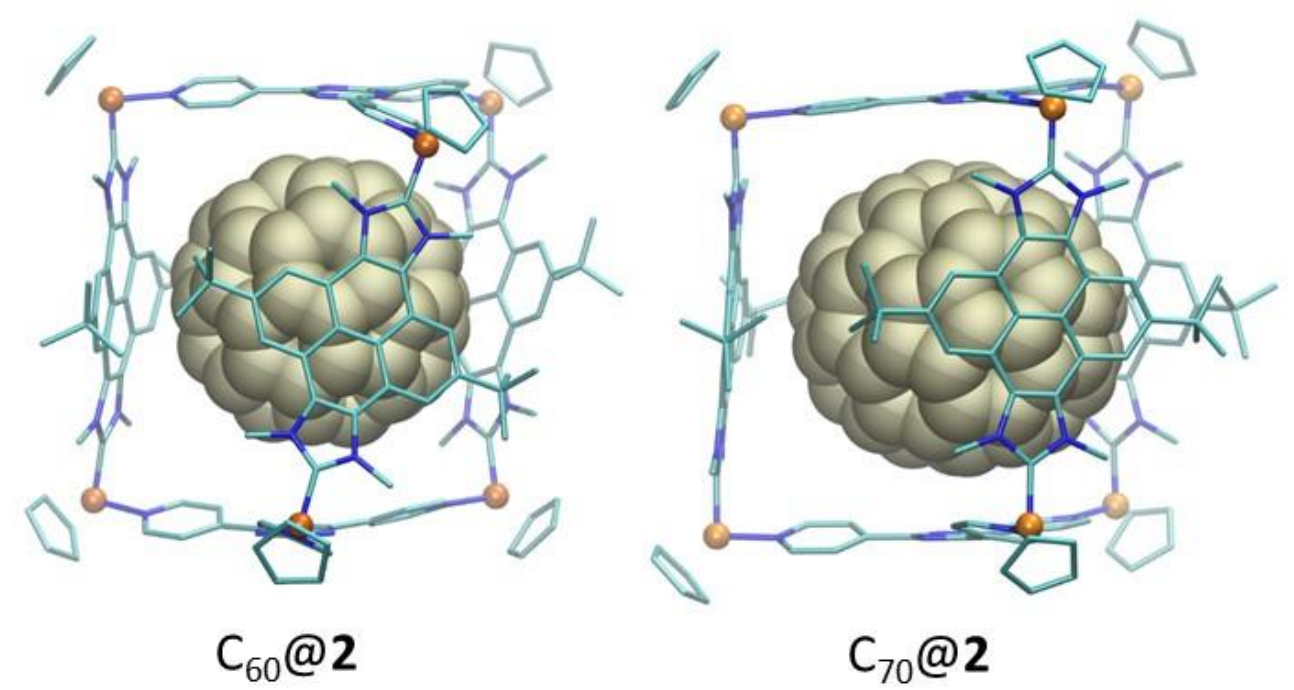

Figure 5. DFT-optimized structures of $\mathrm{C}_{60} @ 2$ (left) and $\mathrm{C}_{70} @ \mathbf{2}$ (right).

The optimized geometry of $\mathrm{C}_{60} @ 2$ reveals how the hexanickel molecular prism can adapt its shape to wrap around the smaller molecule of $\mathrm{C}_{60}$ by twisting the structure about the $z$ axis, thus yielding a molecular shape of the pseudo $D_{3 \mathrm{~d}}$ symmetry. This deformation of the cage closes the distance between the top and bottom TPT ligands and allows a tighter interaction between the surface of the fullerene and the polyaromatic walls of the cage. The twisting of the cage results in a very significant shrinkage of the effective volume, from $1028 \AA^{3}$ in 2 to $698 \AA^{3}$ in $\mathrm{C}_{60} @ \mathbf{2}^{[62]}$ 
The computational study provided data allowing to calculate the enthalpy and Gibbs energy of the substitution reaction: $\mathrm{C}_{60} @ \mathbf{2}+\mathrm{C}_{70} \rightarrow \mathrm{C}_{70} @ \mathbf{2}+\mathrm{C}_{60}$, $\Delta \mathrm{H}=-3.8$ and $\Delta \mathrm{G}=-6.0 \mathrm{kcal} / \mathrm{mol}$ at $298 \mathrm{~K}$, in $o$-dichlorobenzene. The calculated substitution entropy, $\Delta \mathrm{S}=7.5 \mathrm{cal} \cdot \mathrm{mol}^{-1} \cdot \mathrm{K}^{-1}$ is the same as the difference between the experimental encapsulation entropies of $\mathrm{C}_{60}$ and $\mathrm{C}_{70}$, $\Delta \mathrm{S}=7 \mathrm{cal} \cdot \mathrm{mol}^{-1} \cdot \mathrm{K}^{-1}$, although the excellent agreement is probably fortuitous. We note, however, that the calculated encapsulation enthalpy of $\mathrm{C}_{70}$ suggests a more favorable process than that of $\mathrm{C}_{60}$, whereas the experimental encapsulation enthalpies are practically the same for both fullerenes. The $\Delta H$ values are relatively small; thus, they can be influenced by both computational and experimental errors. Nevertheless, proposing that the larger $\mathrm{C}_{70}$ can be more favorably accommodated in $2 \mathrm{vs}$. the smaller $\mathrm{C}_{60}$ is not unreasonable. 


\section{Conclusions}

In summary, we prepared a NHC-based molecular prism that acts as a selective receptor for $\mathrm{C}_{70}$ over $\mathrm{C}_{60}$, and facilitates the selective binding of the former from a mixture of the two. We also proved that the cage shows fullerene binding and release properties, with potential applications in the purification of mixtures of fullerenes. As suggested by the DFT studies, the supramolecular cage is able to modulate the size of the cavity for adapting to the shape of the fullerene guest, thus it can be considered as a 'breathable' structure. Our work also demonstrates how NHC ligands can provide a competitive alternative to the classical Werner-type ligands in the design of supramolecular coordination cages for host-guest chemistry purposes.

\section{Acknowledgements}

We thank MINECO of Spain (CTQ2014-51999-P) and the Universitat Jaume I (P11B2014-02) for financial support. We are grateful to the Serveis Centrals d'Instrumentació Científica (SCIC) of the Universitat Jaume I for providing access to their facilities. We would like to thank Dr. GuisadoBarrios for his support in the determination of the X-ray crystal structure of 2.

Keywords: supramolecular coordination cage (SSC) • N-heterocyclic carbene $\bullet$ Host-guest chemistry $\bullet$ fullerene $\bullet$ self-assembly 


\section{References}

1. Brown, C.J., et al., Supramolecular Catalysis in Metal-Ligand Cluster Hosts. Chemical Reviews, 2015. 115(9): p. 3012-3035.

2. Leenders, S.H.A.M., et al., Transition metal catalysis in confined spaces. Chemical Society Reviews, 2015. 44: p. 433-448.

3. Dydio, P. and J.N.H. Reek, Supramolecular control of selectivity in transition-metal catalysis through substrate preorganization. Chemical Science, 2014. 5(6): p. 2135-2145.

4. Koblenz, T.S., J. Wassenaar, and J.N.H. Reek, Reactivity within a confined self-assembled nanospace. Chemical Society Reviews, 2008. 37(2): p. 247-262.

5. Raynal, M., et al., Supramolecular catalysis. Part 1: non-covalent interactions as a tool for building and modifying homogeneous catalysts. Chemical Society Reviews, 2014. 43(5): p. 1660-1733.

6. Sinha, I. and P.S. Mukherjee, Chemical Transformations in Confined Space of Coordination Architectures. Inorganic Chemistry, 2018: p. DOI: 10.1021/acs.inorgchem.7b03067.

7. Li, Z.J., et al., Supramolecular Engineering of Discrete Pt(II)center dot center dot center dot Pt(II) Interactions for Visible-Light Photocatalysis. Acs Catalysis, 2017. 7(7): p. 4676-4681.

8. Dong, S., et al., Supramolecular Polymers Constructed from Macrocycle-Based Host-Guest Molecular Recognition Motifs. Accounts of Chemical Research, 2014. 47(7): p. 1982-1994.

9. Ariga, K., et al., Molecular recognition: from solution science to nano/materials technology. Chemical Society Reviews, 2012. 41(17): p. $5800-5835$.

10. Chen, B., S. Xiang, and G. Qian, Metal-Organic Frameworks with Functional Pores for Recognition of Small Molecules. Accounts of Chemical Research, 2010. 43(8): p. 1115-1124.

11. Galan, A. and P. Ballester, Stabilization of reactive species by supramolecular encapsulation. Chemical Society Reviews, 2016. 45(6): p. 1720-1737.

12. Schmidt, A., et al., Evaluation of New Palladium Cages as Potential Delivery Systems for the Anticancer Drug Cisplatin. Chemistry-a European Journal, 2016. 22(7): p. 2253-2256. 
13. Zheng, Y.-R., et al., Encapsulation of Pt(IV) prodrugs within a Pt(II) cage for drug delivery. Chemical Science, 2015. 6(2): p. 1189-1193.

14. Therrien, B., Drug Delivery by Water-Soluble Organometallic Cages, in Chemistry of Nanocontainers, M. Albrecht and F.E. Hahn, Editors. 2012. p. 35-55.

15. Schmitt, F., et al., Organometallic Cages as Vehicles for Intracellular Release of Photosensitizers. Journal of the American Chemical Society, 2012. 134(2): p. 754-757.

16. Barry, N.P.E., et al., Excellent Correlation between Drug Release and Portal Size in Metalla-Cage Drug-Delivery Systems. Chemistrya European Journal, 2011. 17(35): p. 9669-9677.

17. Zava, O., et al., Evidence for Drug Release from a Metalla-Cage Delivery Vector Following Cellular Internalisation. Chemistry-a European Journal, 2010. 16(5): p. 1428-1431.

18. Therrien, B., et al., The "Complex-in-a-Complex" cations (acac)(2)M subset of RU6(p-iPrC(6)H(4)Me)(6)(tpt)(2)(dhbq)(3) (6+): A Trojan horse for cancer cells. Angewandte Chemie-International Edition, 2008. 47(20): p. 3773-3776.

19. Cook, T.R., et al., Biomedical and Biochemical Applications of SelfAssembled Metallacycles and Metallacages. Accounts of Chemical Research, 2013. 46(11): p. 2464-2474.

20. Castilla, A.M., W.J. Ramsay, and J.R. Nitschke, Stereochemistry in Subcomponent Self-Assembly. Accounts of Chemical Research, 2014. 47(7): p. 2063-2073.

21. Clever, G.H. and P. Punt, Cation Anion Arrangement Patterns in Self-Assembled Pd2L4 and Pd4L8 Coordination Cages. Accounts of Chemical Research, 2017. 50(9): p. 2233-2243.

22. Han, M., D.M. Engelhard, and G.H. Clever, Self-assembled coordination cages based on banana-shaped ligands. Chemical Society Reviews, 2014. 43(6): p. 1848-1860.

23. Lescop, C., Coordination-Driven Syntheses of Compact Supramolecular Metallacycles toward Extended Metallo-organic Stacked Supramolecular Assemblies. Accounts of Chemical Research, 2017. 50(4): p. 885-894.

24. Zarra, S., et al., Molecular containers in complex chemical systems. 
Chemical Society Reviews, 2015. 44(2): p. 419-432.

25. Tian, Y.K., et al., Responsive Supramolecular Polymers Based on the Bis alkynylplatinum(II) Terpyridine Molecular Tweezer/Arene Recognition Motif. Angewandte Chemie-International Edition, 2014. 53(24): p. 6090-6094.

26. Ronson, T.K., W. Meng, and J.R. Nitschke, Design Principles for the Optimization of Guest Binding in Aromatic-Paneled (Fe4L6)-L-II Cages. Journal of the American Chemical Society, 2017. 139(28): p. 9698-9707.

27. Garcia-Simon, C., M. Costas, and X. Ribas, Metallosupramolecular receptors for fullerene binding and release. Chemical Society Reviews, 2016. 45(1): p. 40-62.

28. Kishi, N., M. Akita, and M. Yoshizawa, Selective Host-Guest Interactions of a Transformable Coordination Capsule/Tube with Fullerenes. Angewandte Chemie-International Edition, 2014. 53(14): p. 3604-3607.

29. Garcia-Simon, C., et al., Sponge-like molecular cage for purification of fullerenes. Nature Communications, 2014. 5: p. Article number: 5557.

30. Frischmann, P.D., et al., Role of Entropy and Autosolvation in Dimerization and Complexation of $\mathrm{C}-60$ by $\mathrm{Zn}-7$ Metallocavitands. Inorganic Chemistry, 2012. 51(6): p. 3443-3453.

31. Mejuto, C., et al., Self-Assembly of Di-N-Heterocyclic Carbene-GoldAdorned Corannulenes on C-60. Chemistry-a European Journal, 2017. 23(44): p. 10644-10651.

32. Sygula, A., Corannulene-Adorned Molecular Receptors for Fullerenes Utilizing the pi-pi Stacking of Curved-Surface Conjugated Carbon Networks. Design, Synthesis and Testing. Synlett, 2016. 27(14): p. 2070-2080.

33. Kawase, T. and H. Kurata, Ball-, bowl-, and belt-shaped conjugated systems and their complexing abilities: Exploration of the concaveconvex pi-pi interaction. Chemical Reviews, 2006. 106(12): p. 52505273.

34. Canevet, D., E.M. Perez, and N. Martin, Wraparound Hosts for Fullerenes: Tailored Macrocycles and Cages. Angewandte ChemieInternational Edition, 2011. 50(40): p. 9248-9259. 
35. Govindarajan, R., R. Nagarajaprakash, and B. Manimaran, Synthesis, Structural Characterization, and Host-Guest Studies of Aminoquinonato-Bridged Re(I) Supramolecular Rectangles. Inorganic Chemistry, 2015. 54(22): p. 10686-10694.

36. Lopez-Vidal, E.M., et al., Metallacycle-Catalyzed SNAr Reaction in Water: Supramolecular Inhibition by Means of Host-Guest Complexation. Journal of Organic Chemistry, 2014. 79(3): p. 12651270.

37. Alvarino, C., et al., Dimensional Matching of Polycyclic Aromatics with Rectangular Metallacycles: Insertion Modes Determined by $C$ $H$ center dot center dot center dot pi Interactions. Chemistry-a European Journal, 2013. 19(45): p. 15329-15335.

38. Blanco, V., et al., Complexation and Extraction of PAHs to the Aqueous Phase with a Dinuclear Pt-II Diazapyrenium-Based Metallacycle. Chemistry-a European Journal, 2010. 16(41): p. 1237312380 .

39. Peinador, C., et al., Complexation of Pyrene in Aqueous Solution with a Self-Assembled Palladium Metallocycle. Organic Letters, 2010. 12(7): p. 1380-1383.

40. Yuan, M.H., et al., Synthesis and Electrochemical Behavior of a Zwitterion-Bridged Metalla-Cage. Organometallics, 2014. 33(18): p. 5043-5045.

41. Garcia, M.D., et al., Complexation of aromatic compounds with selfassembled Pd-II and Pt-II metallacycles. Inorganica Chimica Acta, 2014. 417: p. 27-37.

42. Kishi, N., et al., Wide-Ranging Host Capability of a Pd-II-Linked M2L4 Molecular Capsule with an Anthracene Shell. Chemistry-a European Journal, 2013. 19(20): p. 6313-6320.

43. Martinez-Agramunt, V., S. Ruiz-Botella, and E. Peris, NickelCornered Molecular Rectangles as Polycyclic Aromatic Hydrocarbon Receptors. Chemistry-a European Journal, 2017. 23(27): p. 6675-6681.

44. Sinha, N. and F.E. Hahn, Metallosupramolecular Architectures Obtained from PoIy-N-heterocyclic Carbene Ligands. Accounts of Chemical Research, 2017. 50(9): p. 2167-2184.

45. Mas-Marza, E., J.A. Mata, and E. Peris, Triazolediylidenes: A 
versatile class of ligands for the preparation of discrete molecules of homo- and hetero-binuclear complexes for improved catalytic applications. Angewandte Chemie-International Edition, 2007. 46(20): p. 3729-3731.

46. Gonell, S., M. Poyatos, and E. Peris, Pyrene-Based Bisazolium Salts: From Luminescence Properties to Janus-Type Bis-N-Heterocyclic Carbenes. Chemistry-a European Journal, 2014. 20(31): p. 97169724.

47. Prades, A., E. Peris, and M. Alcarazo, Pyracenebis(imidazolylidene): a new Janus-type biscarbene and its coordination to rhodium and iridium. Organometallics, 2012. 31(12): p. 4623-4626.

48. Valdes, H., M. Poyatos, and E. Peris, A Nanosized Janus Bis-Nheterocyclic Carbene Ligand Based on a Quinoxalinophenanthrophenazine Core, and Its Coordination to Iridium. Organometallics, 2015. 34(9): p. 1725-1729.

49. Valdes, H., M. Poyatos, and E. Peris, A Pyrene-Based N-Heterocyclic Carbene: Study of Its Coordination Chemistry and Stereoelectronic Properties. Organometallics, 2014. 33(1): p. 394-401.

50. Ibañez, S., M. Poyatos, and E. Peris, A D-3h-symmetry hexaazatriphenylene-tris- $N$-heterocyclic carbene ligand and its coordination to iridium and gold: preliminary catalytic studies. Chemical Communications, 2017. 53(26): p. 3733-3736.

51. Nuevo, D., et al., Platinum-Based Organometallic Folders for the Recognition of Electron-Deficient Aromatic Substrates. Chemistry-a European Journal, 2017. 23(30): p. 7272-7277.

52. Biz, C., et al., Gold(I) Metallo-Tweezers for the Recognition of Functionalized Polycyclic Aromatic Hydrocarbons by Combined pipi Stacking and H-Bonding. Chemistry-a European Journal, 2017. 23(58): p. 14439-14444.

53. Ibañez, S., M. Poyatos, and E. Peris, Cation-Driven Self-Assembly of a Gold(I)-Based Metallo-Tweezer. Angewandte Chemie-International Edition, 2017. 56(33): p. 9786-9790.

54. Hahn, F.E., et al., A Nickel(II)-Cornered Molecular Rectangle with Biscarbene and 4,4'-Bipyridine Bridging Groups. Organometallics, 2008. 27(24): p. 6408-6410.

55. Haino, T., M. Yanase, and Y. Fukazawa, Fullerenes enclosed in 
bridged calix 5 arenes. Angewandte Chemie-International Edition, 1998. 37(7): p. 997-998.

56. Yang, D.C., M. Li, and C.F. Chen, A bis-corannulene based molecular tweezer with highly sensitive and selective complexation of C-70 over C-60. Chemical Communications, 2017. 53(67): p. 93369339.

57. Markiewicz, G., et al., Selective $C-70$ encapsulation by a robust octameric nanospheroid held together by 48 cooperative hydrogen bonds. Nature Communications, 2017. 8.

58. Estimation of volume was made using the swisspdb software, available at http://www.expasy.org/spdbv/.

59. Le, V.H., et al., Thermodynamics of Host Guest Interactions between Fullerenes and a Buckycatcher. Journal of Physical Chemistry B, 2014. 118(41): p. 11956-11964.

60. Stukalin, E.B., M.V. Korobov, and N.V. Avramenko, Solvation free energies of the fullerenes $C-60$ and $C-70$ in the framework of polarizable continuum model. Journal of Physical Chemistry B, 2003. 107(36): p. 9692-9700.

61. Yanase, M., et al., Thermodynamic study on supramolecular complex formation of fullerene with calix 5 arenes in organic solvents. Tetrahedron Letters, 2000. 41(4): p. 493-497.

62. Guex, N. and M.C. Peitsch, SWISS-MODEL and the SwissPdbViewer: An environment for comparative protein modeling. Electrophoresis, 1997. 18(15): p. 2714-2723.

63. Anderson, H.L., S. Anderson, and J.K.M. Sanders, LIGANDBINDING BY BUTADIYNE-LINKED PORPHYRIA DIMERS, TRIMERS AND TETRAMERS. Journal of the Chemical SocietyPerkin Transactions 1, 1995(18): p. 2231-2245.

64. Dolomanov, O.V., et al., OLEX2: a complete structure solution, refinement and analysis program. Journal of Applied Crystallography, 2009. 42: p. 339-341.

65. Palatinus, L. and G. Chapuis, SUPERFLIP - a computer program for the solution of crystal structures by charge flipping in arbitrary dimensions. Journal of Applied Crystallography, 2007. 40: p. 786790 . 
66. Sheldrick, G.M., SHELXT - Integrated space-group and crystalstructure determination. Acta Crystallographica a-Foundation and Advances, 2015. 71: p. 3-8.

67. Frisch, M.J., et al., Gaussian 16, Revision A 03. 2016, Wallinford, CT: Gaussian, Inc.

68. Zhao, Y. and D.G. Truhlar, A new local density functional for maingroup thermochemistry, transition metal bonding, thermochemical kinetics, and noncovalent interactions. Journal of Chemical Physics, 2006. 125(19): p. 194101-194118.

69. Weigend, F., Accurate Coulomb-fitting basis sets for $H$ to $R$ n. Physical Chemistry Chemical Physics, 2006. 8(9): p. 1057-1065.

70. Weigend, F. and R. Ahlrichs, Balanced basis sets of split valence, triple zeta valence and quadruple zeta valence quality for $H$ to $R n$ : Design and assessment of accuracy. Physical Chemistry Chemical Physics, 2005. 7(18): p. 3297-3305.

71. Marenich, A.V., C.J. Cramer, and D.G. Truhlar, Universal Solvation Model Based on Solute Electron Density and on a Continuum Model of the Solvent Defined by the Bulk Dielectric Constant and Atomic Surface Tensions. Journal of Physical Chemistry B, 2009. 113(18): p. 6378-6396.

72. Stewart, J.J.P., Optimization of parameters for semiempirical methods VI: more modifications to the NDDO approximations and re-optimization of parameters. Journal of Molecular Modeling, 2013. 19(1): p. 1-32. 
Host-Guest Systems

International Edition: DOI: 10.1002/anie.201901586 German Edition: DOI: 10.1002/ange.201901586

\title{
A Size-Flexible Organometallic Box for the Encapsulation of Fullerenes
}

\author{
Victor Martínez-Agramunt, Tobias Eder, Heidar Darmandeh, Gregorio Guisado-Barrios, and \\ Eduardo Peris*
}

Dedicated to Prof. Javier A. Cabeza on the occasion of his 60th birthday

\begin{abstract}
A palladium-cornered molecular square with four pyrene-bis(imidazolylidene) bridging ligands is reported. This metallo-polygon can encapsulate $C_{60}$ and $C_{70}$. The $X$-ray diffraction structures of the empty cage as well as the cages complexed with both fullerenes are described. The fullerene encapsulation produces perturbations in the structural parameters of the metallo-square, showing that it can adjust the shape of its cavity to the size of each fullerene.
\end{abstract}

Over the last three decades, coordination self-assembly has evolved into the most effective strategy for the rational construction of discrete supramolecular coordination complexes (SSCs). ${ }^{[1]}$ The directional bonding approach allows the outcome of the self-assembly process to be guided by the information provided by the building units (coordination angles, number of coordination sites, shape and length of the connecting ligands), so that the outcome of the self-assembly process can be predicted with a high level of certainty. Arguably, the presence of cavities with well-defined sizes and shapes that are able to encapsulate selected substrates is the most important property of a self-assembled structure because most of the properties that can result in applications are directly related to the host-guest chemistry of a supramolecular assembly. ${ }^{[1, j, 2]}$ It should be noted that this field of research is dominated by Werner-type coordination complexes, wherein the supramolecular assemblies are connected via oxygen or nitrogen atom donors from multidentate ligands, with very few organometallic carbon donor ligands reported in the literature.

[ㅊ] V. Martínez-Agramunt, T. Eder, H. Darmandeh, Dr. G. Guisado-Barrios, Prof. E. Peris Institute of Advanced Materials (INAM) Centro de Innovación en Química Avanzada (ORFEO-CINQA) Universitat Jaume I

Av. Vicente Sos Baynat s/n. Castellón, 12071 (Spain) E-mail: eperis@uji.es

T. Eder

Current address: Institut für Anorganische und Analytische Chemie Westfälische Wilhelms-Universität Münster

48149 Münster (Germany)

$\mathrm{H}$. Darmandeh

Current address: Chair of Inorganic Chemistry II

Ruhr-Universităt Bochum, 44801 Bochum (Germany)

(9) Supporting information and the ORCID identification number(s) for

the author(s) of this article can be found under:

https://doi.org/10.1002/anie.201901586.
We recently became interested in preparing organometallic hosts based on $\mathrm{N}$-heterocyclic carbene (NHC) ligands for the selective recognition of organic substrates. In particular, by combining a pyrene-bis(imidazolylidene) and bipyridine ligands, we obtained a series of nickel-cornered molecular rectangles, which served as receptors and scavengers of a series of polycyclic aromatic hydrocarbons (PAHs) ${ }^{[4]}$ More recently, by using the same bis-NHC and a tris(pyridyl) ligand, we prepared a hexanickel three-dimensional cage that acted as a selective receptor for $\mathrm{C}_{70}$ over $\mathrm{C}_{60}$, and even facilitated the separation of the former from a mixture of the two compounds ${ }^{[5]}$ Related to this type of research, in a recent contribution, Hahn and co-workers described the synthesis of two Ir- and Pd-based metallosquares ${ }^{\left[{ }^{6}\right]}$ by using a well-known benzo-bis(imidazolylidene) ligand. ${ }^{[7]}$ Despite the structural interest of these two tetrametallic architectures, their dimensions (side length ca. $10 \AA$ ) made them unsuitable for the encapsulation of most common organic substrates, owing to the small volume of the internal cavity. As we surmised that metallo-squares based on NHC bridging ligands should render highly stable supramolecular architectures with very well-defined internal cavities, we pursued the preparation of a similar type of molecule but by using a longer pyrene-imidazolylidene ligand $(13 \AA) \cdot{ }^{[8]}$ This should facilitate the preparation of a metallo-supramolecular architecture with a larger cavity, which is therefore able to trap organic guest molecules. We herein describe the preparation of a metallo-square with palladium corners for the encapsulation of fullerenes $\mathrm{C}_{60}$ and $\mathrm{C}_{70}$.

The reaction between the pyrene-bis(imidazolium) salt 1 and $\left[\mathrm{Pd}(\right.$ allyl $) \mathrm{Cl}_{2}$ in acetonitrile in the presence of $\mathrm{AgBF}$ and $\mathrm{Cs}_{2} \mathrm{CO}_{3}$ afforded the air-stable metallo-square $\mathbf{2}$ in $50 \%$ yield after purification (Scheme 1). The complex was characterized by NMR spectroscopy, mass spectrometry, and elemental analysis. The tetrametallic nature of the supramolecular assembly was confirmed by ESI-TOF-MS measurements, which showed peaks at $m / z 766.42$ and 1050.57. assignable to $\left[M-4 \mathrm{BF}_{4}\right]^{4+}$ and $\left[M-3 \mathrm{BF}_{4}\right]^{3+}$, respectively. The diffusion-ordered NMR spectrum (DOSY) showed that all proton resonances display the same diffusion coefficient in deuterated acetonitrile $\left(7.5 \times 10^{-10} \mathrm{~m}^{2} \mathrm{~s}^{-1}\right.$; see the Supporting Information for details), indicating the presence of a single assembly.

Although complex 2 may be described as a metallosquare, the flat polyaromatic surface of the four pyrene moieties generates a "three-dimensional", rather than a "two- 
Angew. Chem. Int. Ed. 58 (2019) 5682-5686

\section{A size-flexible organometallic box for the encapsulation of fullerenes}

Victor Martínez-Agramunt, ${ }^{[\mathrm{a}]}$ Tobias Eder, ${ }^{[\mathrm{a}] \dagger}$ Heidar Darmandeh, ${ }^{[\mathrm{a}] \dagger \dagger}$ Gregorio Guisado-Barrios ${ }^{[\mathrm{a}]}$ and Eduardo Peris ${ }^{[\mathrm{a}] *}$

${ }^{a}$ Institute of Advanced Materials (INAM). Centro de Innovación en Química Avanzada (ORFEO-CINQA). Av. Vicente Sos Baynat s/n. Universitat Jaume I, 12071 Castellón. Spain.

${ }^{\dagger}$ Current address: Institut für Anorganische und Analytische Chemie, Westfälische Wilhelms-Universität Münster, 48149 Münster, Germany

${ }^{\dagger}$ Current address: Chair of Inorganic Chemistry II, Ruhr-Universität Bochum. 44801 Bochum, Germany.

Dedicated to Prof. Javier A. Cabeza on the occasion of his $60^{\text {th }}$ birthday

\section{Abstract}

A palladium-conjoined molecular square obtained by using a pyrene-bisimidazolylidene ligand is described. This "three-dimensional" metallopolygon is suitable for the encapsulation of $\mathrm{C}_{60}$ and $\mathrm{C}_{70}$. The $\mathrm{X}$-ray 
diffraction structures of the empty and complexed cage with both fullerenes are described. The encapsulation of the fullerenes produces perturbations in the structural parameters of the metallo-square, showing that it can adapt the shape of its cavity to the size of each fullerene.

\section{Communication}

Over the last three decades, coordination self-assembly evolved as the most effective strategy for the rational construction of discrete supramolecular coordination complexes (SSCs). ${ }^{[1-10]}$ The directional bonding approach allows that the outcome of the self-assembly process is guided by the information provided by the building units (coordination angles, number of coordination sites, shape and length of connecting ligands), so that the outcome of the self-assembly process can be predicted with a high level of certainty. Arguably, the presence of cavities with well-defined sizes and shapes able to encapsulate selected substrates is the most important property of a self-assembled structure, because most of the properties that can derive in applications are directly related to the host-guest chemistry of the supramolecular assembly. ${ }^{[6,10-15]}$ It should be noted that this field of research is dominated by Werner-type coordination complexes, wherein the supramolecular assemblies are connected via oxygen or nitrogen donors from multidentate ligands, with very few organometallic-based carbon donor ligands reported in the literature. ${ }^{[16,17]}$

We were recently interested in preparing organometallic hosts based on $\mathrm{N}$ heterocyclic carbene ligands (NHC) for the selective recognition of organic substrates. In particular, by combining a pyrene-bisimidazolylidene and dipyiridine ligands, we obtained a series of nickel-cornered molecular 
rectangles that served as receptors and scavengers of a series of polycyclic aromatic hydrocarbons (PAHs). ${ }^{[18]}$ More recently, by using the same bisNHC and a tris-pyridyl ligand, we prepared a hexa-nickel three- dimensional cage that acted as a selective receptor for $\mathrm{C}_{70}$ over $\mathrm{C}_{60}$, and even facilitated the separation of the former from a mixture of the two. ${ }^{[19]}$ Related to this type of research, in a recent contribution Hahn and co-workers described two Ir- and Pd-based metallo-squares ${ }^{[20]}$ using a benzo-bis-imidazolylidene ligand. $^{[21-23]}$ Despite the structural interest of these two tetrametallic architectures, the dimensions of these structures (side length $\approx 10 \AA$ ) made them unsuitable for the encapsulation of most common organic substrates, due to the small void volume of the internal cavity. Because we thought that metallo-squares based on (only) N-heterocyclic carbene bridging ligands should render highly stable supramolecular architectures, with very welldefined internal cavities, we pursued to obtain a similar type of molecule but using a longer pyrene-imidazolylidene ligand (13 $\AA$ ). ${ }^{[24]}$ This should facilitate the preparation of a metallo-supramolecular architecture with a larger cavity, therefore able to trap organic guest molecules. By following this idea, herein we describe the preparation of a palladium-cornered metallo-square for the encapsulation of fullerenes $\mathrm{C}_{60}$ and $\mathrm{C}_{70}$.

The reaction between the pyrene-bisimidazolium salt, $\mathbf{1}$, and $[\mathrm{Pd}(\text { allyl }) \mathrm{Cl}]_{2}$ in acetonitrile in the presence of $\mathrm{AgBF}_{4}$ and $\mathrm{Cs}_{2} \mathrm{CO}_{3}$, afforded the air-stable palladium-cornered metallo-square 2 in 50\% yield after purification (Scheme 1). The complex was characterized by NMR spectroscopy, mass spectrometry and elemental analysis. The tetrametallic nature of the supramolecular assembly was confirmed by ESI-TOF-MS measurements, which showed peaks at 766.42 and 1050.57 , assigned to $\left[\mathrm{M}-4 \mathrm{BF}_{4}\right]^{4+}$ and $[\mathrm{M}-$ $\left.3 \mathrm{BF}_{4}\right]^{3+}$, respectively. The diffusion-ordered NMR spectroscopy (DOSY), 
showed that all proton resonances display the same diffusion coefficient in deuterated acetonitrile $\left(7.5 \times 10-10 \mathrm{~m}^{2} \mathrm{~s}^{-1}\right.$, see SI for details), indicating the presence of a single assembly.
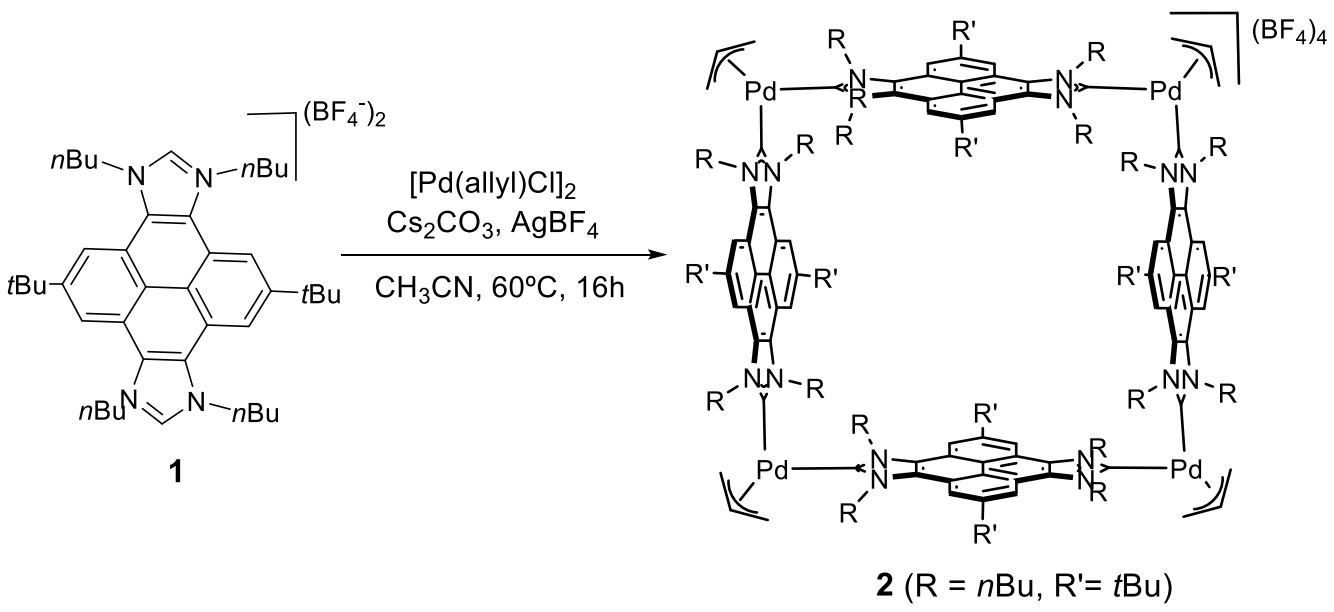

Scheme 1. Preparation of metallo-square 2

Although complex $\mathbf{2}$ may be described as a metallo-square, the flat polyaromatic surface of the four pyrene moieties generates a "threedimensional", rather than a "two-dimensional" macrocyclic cubic box. Given the large size of the internal cavity, we envisioned that complex 2 could be a suitable receptor for large 3-dimensional guests, such as fullerenes $\mathrm{C}_{60}$ and $\mathrm{C}_{70}$. Besides, the flexibility of the torsional angles about the $\mathrm{Pd}-\mathrm{C}_{\mathrm{NHC}}$ bond, should facilitate that the open window is modulated for facilitating the encapsulation of these guest molecules, whose van der Waals diameters are in the 10.1-11.0 A range.

The encapsulation of fullerenes can be performed by dissolving 2 in $\mathrm{CD}_{3} \mathrm{CN}$, in the presence of a suspension of $\mathrm{C}_{60}\left(\right.$ or $\mathrm{C}_{70}$ ), in an NMR tube. Then the mixture is sonicated, and the formation of the host:guest adducts may be 
monitored by ${ }^{1} \mathrm{H}$ NMR spectroscopy. As can be observed form the series of spectra shown in Figure 1, after one hour of sonication in the presence of $\mathrm{C}_{60}$, the ${ }^{1} \mathrm{H}$ NMR spectrum shows the appearance of new signals which are attributed to the formation of the $\mathrm{C}_{60} @ 2$ host:guest complex.

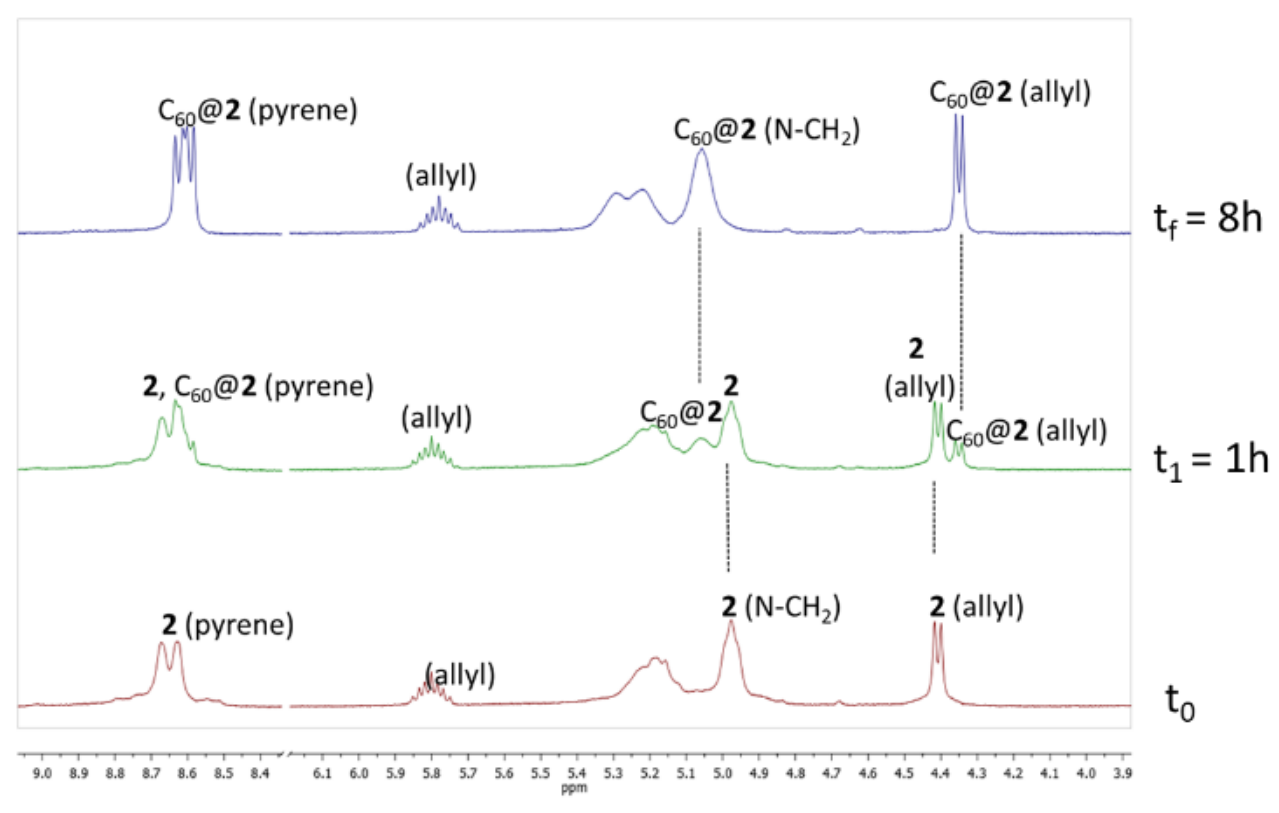

Figure 1. Selected region of the ${ }^{1} \mathrm{H}$ NMR spectra of a mixture of 2 with $\mathrm{C}_{60}$ in $\mathrm{CD}_{3} \mathrm{CN}$. The spectra were recorded immediately after mixing, and after 1 and 8 hours.

The signals due to the protons of the pyrene moiety are slightly downfield shifted, and the two singlets observed for 2 give rise to two well-resolved doublets (clearly observed after $8 \mathrm{~h}$ of sonication). The signal due to one of the diasterotopic protons of the $\mathrm{N}-\mathrm{CH}_{2}$ groups from the $n$-butyls is slightly downfield shifted. Finally, one of the doublets due to the protons of the allyl group is shifted upfield by $0.05 \mathrm{ppm}$, with respect to the same resonance in 2. The spectrum recorded after $8 \mathrm{~h}$ showed only the signals due to $\mathrm{C}_{60} @ \mathbf{2}$, therefore indicating that the reaction was complete. The experiment performed using $\mathrm{C}_{70}$ afforded similar results, indicating the formation of the 
$\mathrm{C}_{70} @ 2$ complex (see SI for more details). These experiments allowed the isolation and full characterization of $\mathrm{C}_{60} @ 2$ and $\mathrm{C}_{70} @ 2$. The ${ }^{13} \mathrm{C} \mathrm{NMR}$ spectrum of $\mathrm{C}_{60} @ \mathbf{2}$ displayed the signal due to the sixty equivalent carbons of the encapsulated fullerene at 141.1 ppm, while the spectrum of $\mathrm{C}_{70} @ 2$ showed four resonances due to $\mathrm{C}_{70}$. At this point, it is important to mention that both fullerenes are completely insoluble in $\mathrm{CD}_{3} \mathrm{CN}$, so the NMRobservable signals are a clear indication of their encapsulation in the metallo-square. The mass spectra of the solutions containing $\mathrm{C}_{60} @ 2$ and $\mathrm{C}_{70} @ \mathbf{2}$,showed peaks at m/z 946.1 and 1290.8 (assigned to $\left[\mathrm{C}_{60} @ \mathbf{2}-4 \mathrm{BF}_{4}\right]^{4+}$ and $\left[\mathrm{C}_{60} @ 2-3 \mathrm{BF}_{4}\right]^{3+}$, respectively), and at 976.2 and 1330.9 (for $\left[\mathrm{C}_{70} @ \mathbf{2}-\right.$ $\left.4 \mathrm{BF}_{4}\right]^{4+}$ and $\left.\left[\mathrm{C}_{70} @ 2-3 \mathrm{BF}_{4}\right]^{3+}\right)$.

For the determination of the association constants we took advantage that the exchange between the host and the host:guest complexes was slow on the ${ }^{1} \mathrm{H}$ NMR timescale, so that the constants could be determined by simply integrating the signals associated to each of the species present in solution. We found that a mixture of acetonitrile:o-dichlorobenzene (1:4) provided the best solubilities for both, the metallo-square and the fullerenes.

The constants were calculated at different 2 /fullerene ratios, and at different temperatures, by using the integration of the signals due to the terminal protons of the allyl groups, which were the ones to show the best conditions for an accurate integration. By doing this, the constants that we obtained at room temperature were $5.4 \times 10^{3} \mathrm{M}^{-1}$ and $7.1 \times 10^{4} \mathrm{M}^{-1}$, for the formation of $\mathrm{C}_{60} @ 2$ and $\mathrm{C}_{70} @ 2$, respectively. The determination of the equilibrium constants at different temperatures allowed us determining the thermodynamic parameters by using corresponding Van't Hoff plots (Figure 2). 

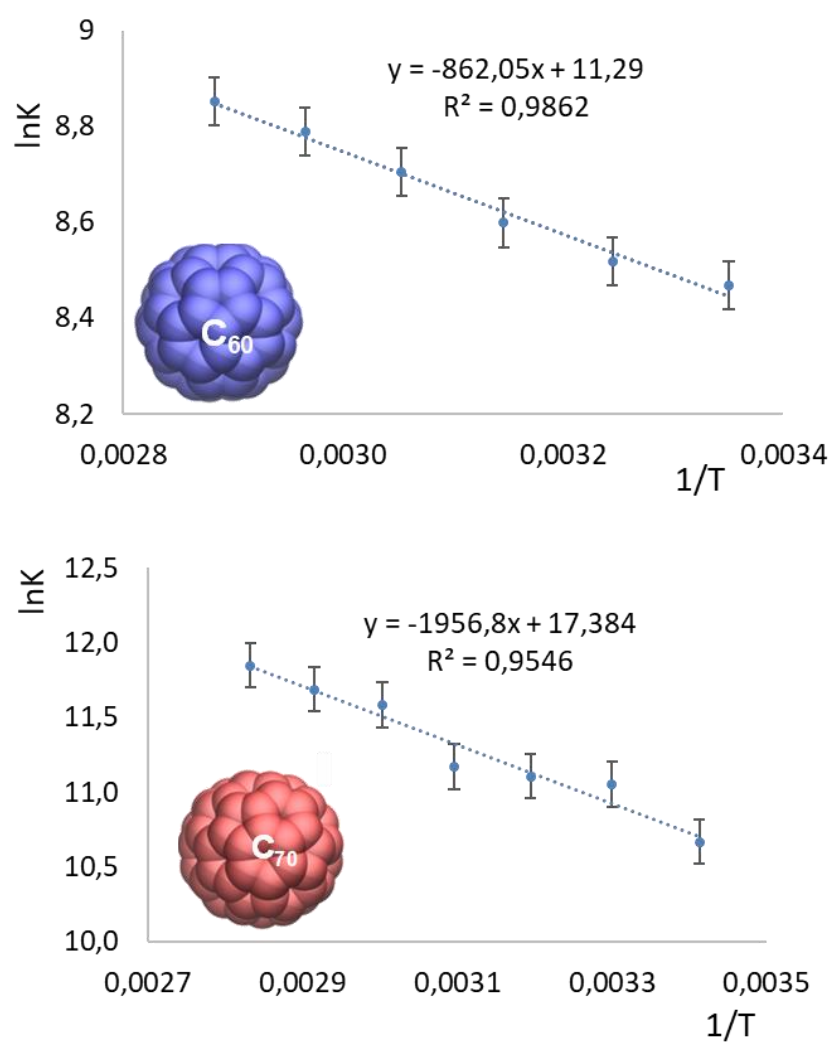

Figure 2. Plots of $\operatorname{lnK}$ vs. 1/T. The plots were built by using the binding constants obtained from the ${ }^{1} \mathrm{H}$ NMR spectra taken at different temperatures, from equimolar solutions $(0.3$ $\mathrm{mM}$ ) of 2 and fullerene in $\mathrm{CD}_{3} \mathrm{CN}$ : o-dichlorobenzene- $\mathrm{d}_{4}$ 1:4. Error bands assume uncertainties of $10 \%$ in binding constant values.

The thermodynamic values found for the encapsulation of $\mathrm{C}_{60}$ were $\Delta \mathrm{H}=1.7$ $\mathrm{kcal} / \mathrm{mol}$ and $\Delta \mathrm{S}=22 \mathrm{cal} / \mathrm{molK}$. For the encapsulation of $\mathrm{C}_{70}$, the values obtained were $\Delta \mathrm{H}=3.9 \mathrm{kcal} / \mathrm{mol}$ and $\Delta \mathrm{S}=34 \mathrm{cal} / \mathrm{molK}$. The small and positive values of the association enthalpies can be explained due to the large solvation enthalpies of the fullerenes in o-dichlorobenzene (the reported experimental solvation enthalpies in o-dichlorobenzene are -30.5 and -35.3 $\mathrm{kcal} / \mathrm{mol}$ for $\mathrm{C}_{60}$ and $\mathrm{C}_{70}$, The large and positive entropy values indicate that 
the process is entropically driven. The larger entropy value found for the encapsulation of $\mathrm{C}_{70}$ is due to its larger surface area, which leads to the presence of a greater number of solvent molecules bound compared to $\mathrm{C}_{60}$. It is important to mention that these thermodynamic parameters are almost identical to the ones that we obtained in a previous work in which we used a nickel-cornered trigonal prismatic supramolecular assembly for the encapsulation of the two same fullerene guests. ${ }^{[19]}$ This may indicate that the electronic nature of the box has a minor importance, since the encapsulation of the three-dimensional guests is dominated by desolvation, rather than to intrinsic interactions between the electron-deficient fullerenes and the electron-rich faces of the pyrene moieties of the metallo-square.

Given the higher affinity of $\mathbf{2}$ for the encapsulation of $\mathrm{C}_{70}$, we designed a competing experiment in which we dissolved the metallo-square in acetonitrile and added an equimolecular mixture of $\mathrm{C}_{60}$ and $\mathrm{C}_{70}$. Then the mixture was sonicated for $2 \mathrm{~h}$. The analysis of the solution by ${ }^{13} \mathrm{C}$ NMR and mass spectrometry indicated that only $\mathrm{C}_{70}$ was encapsulated in $\mathbf{2}$.

The molecular structures of 2, $\mathrm{C}_{60} @ \mathbf{2}$, and $\mathrm{C}_{70} @ \mathbf{2}$ were unambiguously confirmed by means of single crystal X-ray diffraction studies (Figure 3). The comparison of these three structures provides an excellent opportunity for demonstrating experimentally the important structural perturbations produced by the encapsulation of the fullerene guests inside the cavity of the $\mathrm{Pd}_{4}$ metallo-square. The molecular structure of 2 consists of a square-shaped molecule containing four palladium atoms connected by four pyrene-diimidazolylidene ligands (Figure 3, left). The coordination sphere about each palladium atom is completed by one allyl ligand. The average distance between the palladium atoms is $13.25 \AA$. The planes formed by the opposite panels formed by the pyrene-di-NHC ligands of the cage are disposed at an 
average angle of $28.25^{\circ}$. This makes that the quaternary carbons of the tertbutyl groups at opposite pyrene moieties are separated by two closer distances at 9.99 and $11.31 \AA$, and two longer ones at 14.94 and $15.34 \AA$ (only two of these distances are displayed in Figure 3). These measures are important, because they define the limits of the "open window" of the box.
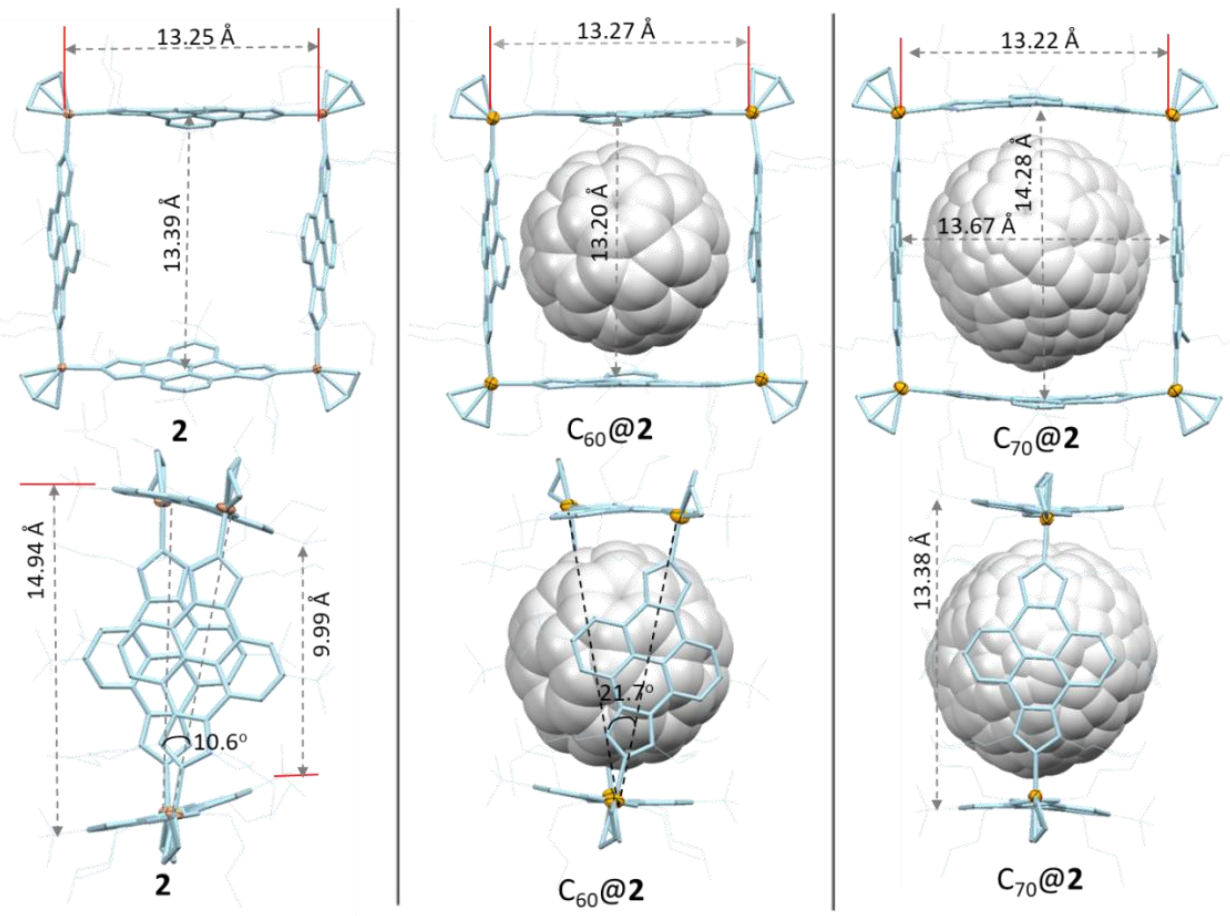

Figure 3. X-ray diffraction structures of 2 (left), $\mathrm{C}_{60} @ 2$ (middle), and $\mathrm{C}_{70} @ 2$ (right), showing some selected dimensions. Hydrogen atoms, counteranions $\left(\mathrm{BF}_{4}^{-}\right)$and solvent molecules have been omitted for clarity. Two molecules of $\mathrm{C}_{70}(0.5$ occupancy each) are shown in the structure of $\mathrm{C}_{70} @ \mathbf{2}$.

The molecular structure of $\mathrm{C}_{60} @ 2$ (Figure 3, middle) shows a molecule of $\mathrm{C}_{60}$ trapped inside the cavity of the $\mathrm{Pd}_{4}$ metallo-square. All four pyrene moieties of the pyrene-di-imidazolylidene ligands are curved, adapting their shapes for a maximum face-to-face interaction with the surface of the fullerene. The metallo-square is twisted, and therefore slightly compressed, 
in order to adapt its size to the size of $\mathrm{C}_{60}$ (see side-on view of the structure). This is reflected by the slight shortening of the distances between the central points of opposite pyrene moieties (13.20 $\AA$ in $\mathrm{C}_{60} @ 2$; $13.39 \AA$ in 2), and by the torsion angles formed by the two Pd-Pd axis [defined by the $\mathrm{Pd}(1)-\mathrm{Pd}(2)-$ $\operatorname{Pd}(3)-\operatorname{Pd}(4)$ dihedral angles], which is $10.6^{\circ}$ for $\mathbf{2}$ and $21.7^{\circ}$ for $\mathrm{C}_{60} @ \mathbf{2}$. The molecular structure of $\mathrm{C}_{70} @ 2$ (Figure 3, right), shows that the encapsulation of the molecule of $\mathrm{C}_{70}$ produces an expansion of the structure of the metallosquare, which looks as 'inflated', compared to the structures of the cage in $\mathbf{2}$ and in $\mathrm{C}_{60} @ \mathbf{2}$. This is reflected by a significant bending of the pyrene moieties, which renders expanded distances of 13.67 and $14.28 \AA$ at the central part of the pyrene fragments. Interestingly, two out of the four N$n$ butyl groups at each pyrene-bis-imidazolylidene ligand are wrapped around the $\mathrm{C}_{70}$ molecule, very likely contributing to enhance the encapsulating abilities of the $\mathrm{Pd}_{4}$ cage.

The determination of the guest-available volume of the cavity of 2, $\mathrm{C}_{60} @ \mathbf{2}$ and $\mathrm{C}_{70} @ 2$ (710, 650 and $696 \AA^{3}$, respectively, after removing the molecules of $\mathrm{C}_{60}$ and $\mathrm{C}_{70}$ ), shows that there is an important shrinkage $(8.5 \%)$ of the volume of the molecule from 2 to $\mathrm{C}_{60} @ 2$ (see ESI for details regarding the calculation of the cavity volumes). ${ }^{[25]}$ Examples of guest-induced sizeadaptable metallocages have been reported previously. ${ }^{[26-28]}$

In summary, we obtained and characterized a NHC-based palladiumcornered metallo-square by using the metal-directed self-assembly strategy. Our organometallic metallo-square is significantly different compared to the most widely used supramolecular assemblies for the encapsulation of fullerenes, which are dominated by structures with Werner-type porphyrincontaining ligands, ${ }^{[29-32]}$ or structures with curved conjugated networks. ${ }^{[33,34]}$ This observation is not trivial, because the presence of the four bis- 
imidazolylidene bridging ligands in our host provides a greater stability to the structure, which remains intact in solution for days without any sign of decomposition. The 'cubic' cage possesses a cavity that makes it suitable for the encapsulation of fullerenes $\mathrm{C}_{60}$ and $\mathrm{C}_{70}$. The cage molecule exhibits higher affinity towards the larger fullerene over the smaller one, an observation that allowed designing a simple experiment for the selective extraction of $\mathrm{C}_{70}$ from a mixture of $\mathrm{C}_{60} / \mathrm{C}_{70}$. The metallo-square is sizeflexible, and therefore able to adapt its shape to the size of the encapsulated fullerene. This is achieved by compressing or expanding the structure and by bending the pyrene moieties in order to maximize the face-to-face overlap with the convex surface of the fullerenes. This bending of the pyrene moiety is counterintuitive, because pyrene and other polyaromatic hydrocabons are traditionally considered as rigid flat structures, so our observations may be used for future applications in the design of surface-adaptable supramolecular receptors.

\section{Acknowledgements}

We gratefully acknowledge financial support from the Universitat Jaume I (UJI-B2017-07). G.G.-B thanks MINECO for a "Juan de la Cierva Fellowship" (GGB, IJCI-2015-23407). V. M.-A. thanks the Generalitat Valenciana for a Ph.D. fellowship. We are grateful to the Serveis Centrals d'Instrumentació Científica (SCIC-UJI) for providing with spectroscopic and X-ray diffraction facilities. We would also like to thank Dr. Gabriel Peris (SCIC-UJI), for his help in the refinement of the crystal structures.

Keywords: N-heterocyclic carbenes $\bullet$ Palladium $\bullet$ Self-assembly $\bullet$ hostguest $\bullet$ fullerene 


\section{References}

1. Cook, T.R. and P.J. Stang, Recent Developments in the Preparation and Chemistry of Metallacycles and Metallacages via Coordination. Chemical Reviews, 2015. 115(15): p. 7001-7045.

2. Cook, T.R., Y.-R. Zheng, and P.J. Stang, Metal-Organic Frameworks and Self-Assembled Supramolecular Coordination Complexes: Comparing and Contrasting the Design, Synthesis, and Functionality of Metal-Organic Materials. Chemical Reviews, 2013. 113(1): p. 734-777.

3. Gianneschi, N.C., M.S. Masar, and C.A. Mirkin, Development of a coordination chemistry-based approach for functional supramolecular structures. Accounts of Chemical Research, 2005. 38(11): p. 825-837.

4. Caulder, D.L. and K.N. Raymond, Supermolecules by design. Accounts of Chemical Research, 1999. 32(11): p. 975-982.

5. Chakrabarty, R., P.S. Mukherjee, and P.J. Stang, Supramolecular Coordination: Self-Assembly of Finite Two- and Three-Dimensional Ensembles. Chemical Reviews, 2011. 111(11): p. 6810-6918.

6. Castilla, A.M., W.J. Ramsay, and J.R. Nitschke, Stereochemistry in Subcomponent Self-Assembly. Accounts of Chemical Research, 2014. 47(7): p. 2063-2073.

7. McConnell, A.J., et al., Stimuli-Responsive Metal-Ligand Assemblies. Chemical Reviews, 2015. 115(15): p. 7729-7793.

8. Fujita, M. and K. Ogura, Transition-metal-directed assembly of welldefined organic architectures possessing large voids: From macrocycles to 2 catenanes. Coordination Chemistry Reviews, 1996. 148: p. 249-264.

9. Fujita, M., Metal-directed self-assembly of two- and threedimensional synthetic receptors. Chemical Society Reviews, 1998. 27(6): p. 417-425.

10. Han, M., D.M. Engelhard, and G.H. Clever, Self-assembled coordination cages based on banana-shaped ligands. Chemical Society Reviews, 2014. 43(6): p. 1848-1860.

11. Clever, G.H. and P. Punt, Cation Anion Arrangement Patterns in Self-Assembled Pd2L4 and Pd4L8 Coordination Cages. Accounts of 
Chemical Research, 2017. 50(9): p. 2233-2243.

12. Lescop, C., Coordination-Driven Syntheses of Compact Supramolecular Metallacycles toward Extended Metallo-organic Stacked Supramolecular Assemblies. Accounts of Chemical Research, 2017. 50(4): p. 885-894.

13. Zarra, S., et al., Molecular containers in complex chemical systems. Chemical Society Reviews, 2015. 44(2): p. 419-432.

14. Tian, Y.K., et al., Responsive Supramolecular Polymers Based on the Bis alkynylplatinum(II) Terpyridine Molecular Tweezer/Arene Recognition Motif. Angewandte Chemie-International Edition, 2014. 53(24): p. 6090-6094.

15. Yoshizawa, M., J.K. Klosterman, and M. Fujita, Functional Molecular Flasks: New Properties and Reactions within Discrete, Self-Assembled Hosts. Angewandte Chemie-International Edition, 2009. 48(19): p. 3418-3438.

16. Sinha, N. and F.E. Hahn, Metallosupramolecular Architectures Obtained from PoIy-N-heterocyclic Carbene Ligands. Accounts of Chemical Research, 2017. 50(9): p. 2167-2184.

17. Gan, M.M., et al., Preparation and Post-Assembly Modification of Metallosupramolecular Assemblies from Poly(N-Heterocyclic Carbene) Ligands. Chemical Reviews, 2018. 118(19): p. 9587-9641.

18. Martinez-Agramunt, V., S. Ruiz-Botella, and E. Peris, NickelCornered Molecular Rectangles as Polycyclic Aromatic Hydrocarbon Receptors. Chemistry-a European Journal, 2017. 23(27): p. 6675-6681.

19. Martinez-Agramunt, V., D. Gusev, and E. Peris, A shape-adaptable organometallic supramolecular coordination cage for the encapsulation of fullerenes. Chemistry-a European Journal, 2018. 24(55): p. 14802-14807.

20. Sinha, A., et al., Single-Step Synthesis of Organometallic Molecular Squares from NR,NR',NR',NR',' -Substituted Benzobiscarbenes. Chemistry-a European Journal, 2017. 23(25): p. 5939-5942.

21. Boydston, A.J. and C.W. Bielawski, Bis(imidazolylidene)s as modular building blocks for monomeric and macromolecular organometallic materials. Dalton Transactions, 2006(34): p. 40734077. 
22. Khramov, D.M., A.J. Boydston, and C.W. Bielawski, Synthesis and study of Janus bis(carbene)s and their transition-metal complexes. Angewandte Chemie-International Edition, 2006. 45(37): p. 61866189.

23. Williams, K.A., A.J. Boydston, and C.W. Bielawski, Main-chain organometallic polymers: synthetic strategies, applications, and perspectives. Chemical Society Reviews, 2007. 36(5): p. 729-744.

24. Gonell, S., M. Poyatos, and E. Peris, Pyrene-Based Bisazolium Salts: From Luminescence Properties to Janus-Type Bis-N-Heterocyclic Carbenes. Chemistry-a European Journal, 2014. 20(31): p. 97169724.

25. Guex, N. and M.C. Peitsch, SWISS-MODEL and the SwissPdbViewer: An environment for comparative protein modeling. Electrophoresis, 1997. 18(15): p. 2714-2723.

26. Clegg, J.K., et al., A stimuli responsive system of self-assembled anion-binding Fe4L68+ cages. Chemical Science, 2013. 4(1): p. 6876.

27. Riddell, I.A., et al., Cation- and Anion-Exchanges Induce Multiple Distinct Rearrangements within Metallosupramolecular Architectures. Journal of the American Chemical Society, 2014. 136(26): p. 9491-9498.

28. Ronson, T.K., et al., Pyrene-Edged (Fe4L6)-L-II Cages Adaptively Reconfigure During Guest Binding. Journal of the American Chemical Society, 2014. 136(44): p. 15615-15624.

29. Garcia-Simon, C., M. Costas, and X. Ribas, Metallosupramolecular receptors for fullerene binding and release. Chemical Society Reviews, 2016. 45(1): p. 40-62.

30. Garcia-Simon, C., et al., Sponge-like molecular cage for purification of fullerenes. Nature Communications, 2014. 5: p. Article number: 5557.

31. Meng, W.J., et al., A Self-Assembled M8L6 Cubic Cage that Selectively Encapsulates Large Aromatic Guests. Angewandte Chemie-International Edition, 2011. 50(15): p. 3479-3483.

32. Brenner, W., T.K. Ronson, and J.R. Nitschke, Separation and Selective Formation of Fullerene Adducts within an (M8L6)-L-II Cage. Journal of the American Chemical Society, 2017. 139(1): p. 
75-78.

33. Sygula, A., Corannulene-Adorned Molecular Receptors for Fullerenes Utilizing the pi-pi Stacking of Curved-Surface Conjugated Carbon Networks. Design, Synthesis and Testing. Synlett, 2016. 27(14): p. 2070-2080.

34. Atwood, J.L., G.A. Koutsantonis, and C.L. Raston, PURIFICATION OF C-60 AND C-70 BY SELECTIVE COMPLEXATION WITH CALIXARENES. Nature, 1994. 368(6468): p. 229-231.

35. Ibañez, S., M. Poyatos, and E. Peris, Mono and dimetallic pyreneimidazolylidene complexes of iridium(iii) for the deuteration of organic substrates and the $C$-C coupling of alcohols. Dalton Transactions, 2016. 45(36): p. 14154-14159.

36. Dolomanov, O.V., et al., OLEX2: a complete structure solution, refinement and analysis program. Journal of Applied Crystallography, 2009. 42: p. 339-341.

37. Palatinus, L. and G. Chapuis, SUPERFLIP - a computer program for the solution of crystal structures by charge flipping in arbitrary dimensions. Journal of Applied Crystallography, 2007. 40: p. 786790.

38. Palatinus, L., J. Prathapa, and S. van Smaalen, EDMA: a computer program for topological analysis of discrete electron densities. . J. Appl. Cryst. , 2012. 45: p. 575- 580.

39. Sheldrick, G.M., A short history of SHELX. Acta Crystallographica Section A, 2008. 64: p. 112-122.

40. Sheldrick, G.M., SHELXT - Integrated space-group and crystalstructure determination. Acta Crystallographica a-Foundation and Advances, 2015. 71: p. 3-8.

41. Vandersluis, P. and A.L. Spek, BYPASS - AN EFFECTIVE METHOD FOR THE REFINEMENT OF CRYSTAL-STRUCTURES CONTAINING DISORDERED SOLVENT REGIONS. Acta Crystallographica Section A, 1990. 46: p. 194-201.

42. Spek, A.L., Single-crystal structure validation with the program PLATON. Journal of Applied Crystallography, 2003. 36: p. 7-13. 


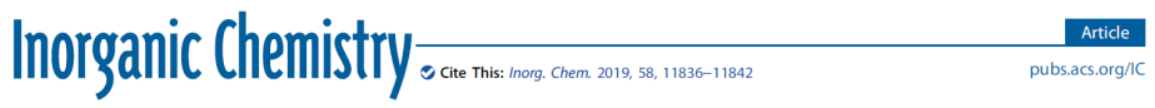

\section{Photocatalytic Properties of a Palladium Metallosquare with Encapsulated Fullerenes via Singlet Oxygen Generation}

Víctor Martínez-Agramunt and Eduardo Peris*๑

Institute of Advanced Materials (INAM), Centro de Innovación en Química Avanzada (ORFEO-CINQA), Universitat Jaume I, Av. Vicente Sos Baynat s/n, Castellón E-12071, Spain

S Supporting Information

ABSTRACT: Singlet oxygen has recently attracted a great
deal of attention due to its strong oxidizing properties, which
makes it useful in organic synthesis and biological studies.
However, the photosensitizers that are required for singlet
oxygen generation remain inadequate due to their often low
thermal and photochemical stabilities. Here we describe the
use of a palladium-conjoined metallosquare with encapsulated
fullerenes $\left(\mathrm{C}_{60}\right.$ or $\left.\mathrm{C}_{70}\right)$, which behaves as an efficient and
photochemically stable singlet oxygen photosensitizer. The
metallocage with the encapsulated fullerenes can oxidize a
series of cyclic and acyclic alkenes at room temperature via
visible light-induced singlet oxygen generation, using oxygen molecules in air at atmospheric pressure. These reactions take
advantage of the excellent spin-converting properties of fullerenes, which make them excellent agents for singlet oxygen
production.

\section{- INTRODUCTION}

Singlet oxygen is widely recognized due to its reactivity with alkenes, ${ }^{1}$ as well as its involvement in clinical photodynamic therapy treatment (PDT) of tumors. ${ }^{2}$ Photocatalyzed reactions involving singlet oxygen constitute an effective way for compound oxidation ${ }^{3}$ and for synthesizing oxygenated structures by facilitating carbon-oxygen and heteroatomoxygen bond formation ${ }^{4}$ with high atom economy and low cost. Singlet $\mathrm{O}_{2}\left({ }^{1} \Delta_{\mathrm{g}}\right)$ is conventionally generated by energy transfer from a photosensitizer to triplet $\mathrm{O}_{2}\left({ }^{3} \Sigma_{\mathrm{g}}\right){ }^{3 \mathrm{~B}, \mathrm{~s}}$ Normally, the photosensitizers are organic dyes that are prone to photoinduced or enzymatic degradation, therefore with limited applicability in PDT protocols and in organic synthesis. Searching for highly efficient photosensitizers with large absorption coefficients and high photochemical stability is currently one of the main challenges for widening the applications of singlet oxygen in organic synthesis and therapeutic research. Fullerenes $\left(\mathrm{C}_{60}\right.$ and $\left.\mathrm{C}_{70}\right)$ have been shown to be efficient photosensitizers for singlet oxygen generation, ${ }^{6}$ but their poor solubility in most common solvents makes them unsuitable for an extensive applicability. This problem has been addressed by some researchers by functionalizing the fullerene core with solubilizing groups, ${ }^{7}$ a method that is hampered by the low product yields obtained and by the need to use complicated reaction procedures. In addition, fullerene-containing systems have also been widely used for light harvesting and energy conversion, ${ }^{8}$ because the strong ultraviolet-visible (UV-vis) absorption together with the large size and symmetrical shape of fullerenes facilitates electron transfer events with applications in light-induced processes. This, in part, explains why research on fullerene receptors based on noncovalent bonding interactions is gaining interest in recent years. ${ }^{9}$ We recently contributed to the design of a series of organometallic-based receptors for the encapsulation of fullerenes by using metallosupramolecular structures with di-N-heterocyclic carbene (NHC) ligands connected by rigid $\pi$-conjugated polyaromatic systems. ${ }^{10}$ Compared to the most widely used Werner-type metallosupramolecular assemblies, ${ }^{11}$ organometallic-based supramolecular coordination complexes supported by N-heterocyclic carbene ligands ${ }^{12}$ have the advantage of their higher stability, which is arguably attributed to the strength of the M$\mathrm{C}_{\text {camene }}$ bond. In one of our most recent contributions, ${ }^{10 c}$ we described a palladium-cornered metallosquare supported by a pyrene-dimidazolylidene ligand, which showed very high affinities for fullerenes $\mathrm{C}_{60}$ and $\mathrm{C}_{70}$ (Scheme 1). Given the high solubility $\left(>10 \mathrm{mM}\right.$ in organic solvents such as $\mathrm{CH}_{3} \mathrm{CN}$,

Scheme 1. Fullerene-Containing Metallocages Used in This Study

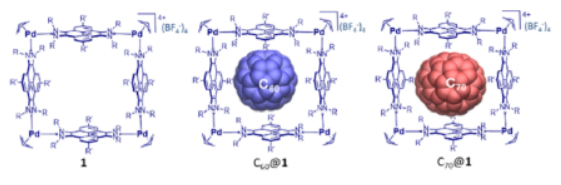

Received: July 13, 2019

Published: August 12, 2019 
Inorg. Chem. 58 (2019) 11836-11842

\title{
Photocatalytic properties of a palladium metallosquare with encapsulated fullerenes via singlet oxygen generation
}

\author{
Víctor Martínez-Agramunt and Eduardo Peris* \\ ${ }^{\text {a }}$ Institute of Advanced Materials (INAM). Centro de Innovación en Química \\ Avanzada (ORFEO-CINQA). Av. Vicente Sos Baynat s/n. Universitat \\ Jaume I, 12071 Castellón. Spain.
}

\begin{abstract}
Singlet oxygen has won recently a great deal of attention due to its strong oxidizing properties, which makes it useful in organic synthesis and biological studies. However, the photosensitizers that are required for singlet oxygen generation remain inadequate due to their often low thermal and photochemical stabilities. Here we describe the use of a palladium-conjoined metallosquare with encapsulated fullerenes $\left(\mathrm{C}_{60}\right.$ or $\left.\mathrm{C}_{70}\right)$, which behaves as an efficient and photochemically stable singlet oxygen photosensitizer. The metallocage with the encapsulated fullerenes is able to oxidize a series of cyclic and acyclic alkenes at room temperature via visible light-induced
\end{abstract}


singlet oxygen generation, using oxygen molecules in air at atmospheric pressure. These reactions take advantage of the excellent spin-converting properties of fullerenes, which make them excellent agents for singlet oxygen production.

\section{Introduction}

Singlet oxygen is widely recognized due to its reactivity with alkenes, ${ }^{[1-5]}$ as well as its involvement in clinical photodynamic therapy treatment (PDT) of tumors. ${ }^{[6-10]}$ Photocatalyzed reactions involving singlet oxygen constitute an effective way for compound oxidation, ${ }^{[11-13]}$ and for synthesizing oxygenated structures by facilitating carbon-oxygen and heteroatom-oxygen bond formation ${ }^{[14-17]}$ with high atom economy and low cost. Singlet $\mathrm{O}_{2}\left({ }^{1} \Delta_{\mathrm{g}}\right)$ is conventionally generated by energy transfer from a photosensitizer to triplet $\mathrm{O}_{2}\left({ }^{3} \Sigma_{\mathrm{g}}\right) .{ }^{[12,18-20]}$ Normally, the photosensitizers are organic dyes that are prone to photoinduced or enzymatic degradation, therefore with limited applicability in PDT protocols and in organic synthesis. Searching for highly efficient photosensitizers with large absorption coefficients and high photochemical stability is currently one of the main challenges for widening the applications of single oxygen in organic synthesis and therapeutic research. Fullerenes $\left(\mathrm{C}_{60}\right.$ and $\left.\mathrm{C}_{70}\right)$ have shown to be efficient photosensitizers for singlet oxygen generation, ${ }^{[21,22]}$ but their poor solubility in most common solvents makes them unsuitable for an extensive applicability. This problem has been addressed by some researchers by functionalizing the fullerene core with solubilizing groups, ${ }^{[23-28]}$ a method that is hampered by the low product yields obtained and by the need of using 
complicated reaction procedures. In addition, fullerene-containing systems have also been widely used for light-harvesting and energy conversion, ${ }^{[29-36]}$ because the strong UV/Vis absorption together with the large size and symmetrical shape of fullerenes facilitates electron transfer events with applications in light-induced processes. This, in part, explains why research on fullerene receptors based on non-covalent bonding interactions is gaining interest in recent years. ${ }^{[37-40]}$ We recently contributed to the design of a series of organometallic-based receptors for the encapsulation of fullerenes by using metallosupramolecular structures with di-N-heterocyclic carbene (NHC) ligands connected by rigid $\pi$-conjugated polyaromatic systems. ${ }^{[41-43]}$ Compared to the most widely used Werner-type metallosupramolecular assemblies, ${ }^{[44-53]}$ organometallic-based supramolecular coordination complexes supported by N-heterocyclic carbene ligands ${ }^{[54,55]}$ have the advantage of their higher stability, which is arguably attributed to the strength of the $\mathrm{M}-\mathrm{C}_{\text {carbene }}$ bond.

In one of our most recent contributions, ${ }^{[43]}$ we described a palladiumcornered metallosquare supported by a pyrene-di-midazolylidene ligand, which showed very high affinities for fullerenes $\mathrm{C}_{60}$ and $\mathrm{C}_{70}$ (Scheme 1).
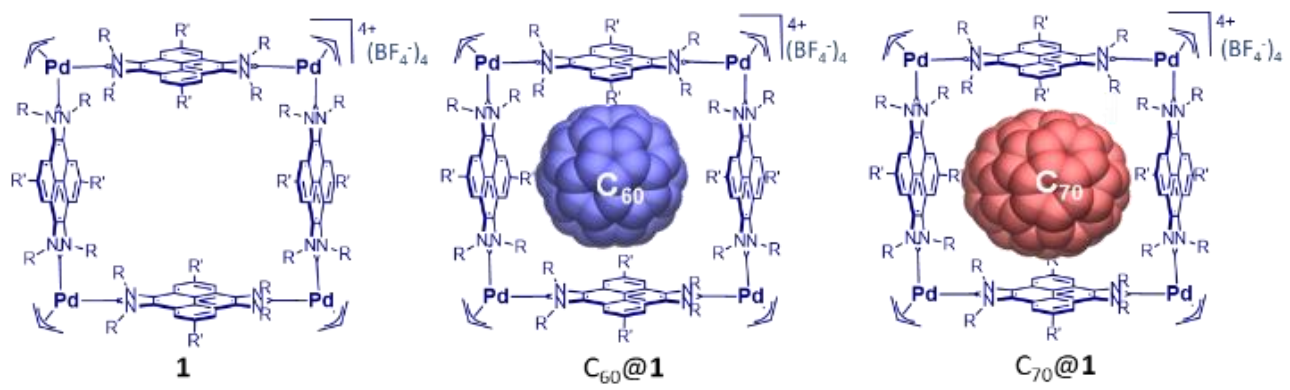

Scheme 1. Fullerene-containing metallocages used in this study 
Given the high solubility ( $>10 \mathrm{mM}$ in organic solvents such as $\mathrm{CH}_{3} \mathrm{CN}$, $\mathrm{CH}_{2} \mathrm{Cl}_{2}, \mathrm{CHCl}_{3}$, etc.) and stability of this complex and its related host:guest adducts with encapsulated fullerenes, we thought that we could take advantage of the spin transfer properties of the encapsulated fullerenes for finding their applicability in challenging organic transformations.

In this study we describe the use of the fullerene host:guest complexes $\mathrm{C}_{60} @ \mathbf{1}$ and $\mathrm{C}_{70} @ \mathbf{1}$, as photosensitizers for the generation of singlet $\mathrm{O}_{2}$, and for facilitating carbon-oxygen bond forming reactions with a variety of organic substrates.

\section{Results and Discussion}

We first analysed the photophysical properties of 1, $\mathrm{C}_{60} @ \mathbf{1}$ and $\mathrm{C}_{70} @ \mathbf{1}$ by studying their electronic and emission spectra. The UV-vis spectra of $\mathrm{C}_{60} @ 1$ and $\mathrm{C}_{70} @ 1$ show a weak absorption band beyond 500 nm (see ESI). This band (not observed in the UV-vis spectrum of 1) is assigned to $S_{0} \rightarrow S_{n}$ transitions of the fullerenes. The spectra also show the bands due to the absorption of the pyrene moieties of the bridging ligands of the complex, between 300 and $360 \mathrm{~nm}$. The photoinduced energy transfer of the host:guest complexes was analysed by luminescence studies. Complex $\mathbf{1}$ alone gives intense fluorescence due to the emission of the pyrene fragment, with a vibronically-resolved band with a maximum at $405 \mathrm{~cm}^{-1}$. This band is quenched in $\mathrm{C}_{60} @ \mathbf{1}$ and $\mathrm{C}_{70} @ \mathbf{1}$, indicating energy transfer from the host to the fullerene.

The evaluation of the photosensitizing efficiency of $\mathrm{C}_{60} @ \mathbf{1}$ and $\mathrm{C}_{70} @ \mathbf{1}$ was carried out in acetonitrile, by measuring the phosphorescence emission 
spectra of singlet oxygen generated by the photosensitizer upon irradiation with visible light. The near-infra-red (NIR) phosphorescence serves as a direct and unambiguous marker for the existence of $\left.{ }^{1} \mathrm{O}_{2} \cdot{ }^{[7}, 18,19\right]$ Photoirradiated samples of $\mathrm{C}_{60} @ \mathbf{1}$ and $\mathrm{C}_{70} @ \mathbf{1}$ in aerated acetonitrile, clearly showed the NIR ${ }^{1} \mathrm{O}_{2}$ luminescence around $1270 \mathrm{~nm}$ upon excitation with 532 $\mathrm{nm}$ laser light (Figure 1). Under the same conditions, the empty cage $1 \mathrm{did}$ not produce any measurable phosphorescence. We estimated a ${ }^{1} \mathrm{O}_{2}$ quantum yield of $\Phi_{\Delta}=0.23$ and 0.41 , for $\mathrm{C}_{60} @ 1$ and $\mathrm{C}_{70} @ 1$, respectively, by comparing the integrated areas determined for the samples and Rose Bengal used as standard $\left(\Phi_{\Delta}=0.71\right)$.[56] These $\Phi_{\Delta}$ values for the inclusion complexes are considerably lower than those reported for $\mathrm{C}_{60}$ and $\mathrm{C}_{70}$ (in $\mathrm{C}_{6} \mathrm{H}_{6}$ ), which are known to be very close to unity. ${ }^{[57,58]}$

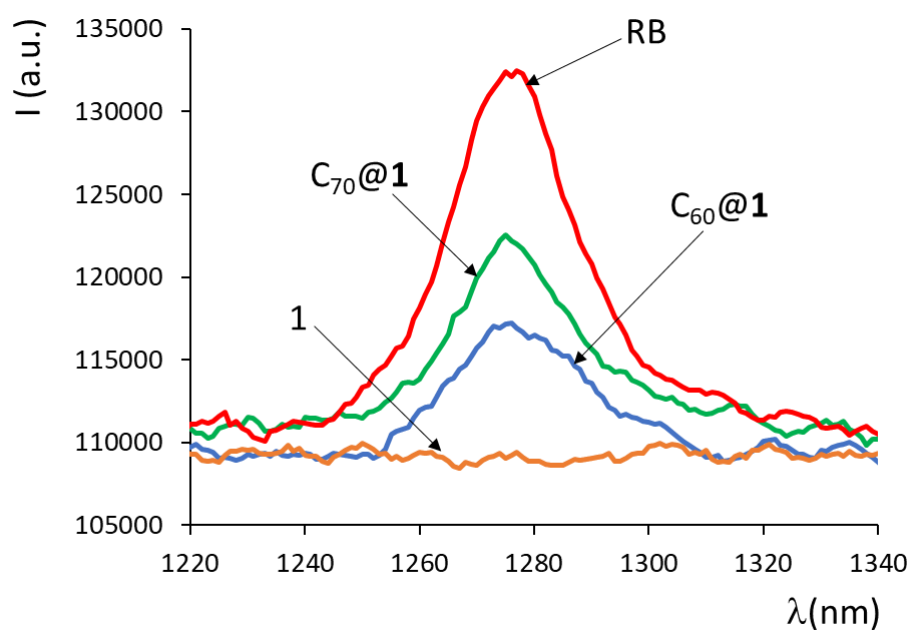

Figure 1. Near infrared singlet oxygen phosphorescent emission spectra sensitized by Rose Bengal (RB), 1, $\mathrm{C}_{60} @ 1$ and $\mathrm{C}_{70} @ 1\left(1.25 \times 10^{-4} \mathrm{M}\right.$ in $\left.\mathrm{CH}_{3} \mathrm{CN}, \lambda_{\mathrm{ex}}=532 \mathrm{~nm}\right)$. 
A possible explanation for this may be the quenching of ${ }^{1} \mathrm{O}_{2}$ by the complex before it can escape the solvent cage, but most likely it is due to reduction of the sentitizer-to-oxygen energy transfer efficiency as a consequence of the energy-transfer interactions between the fullerenes and the host. It should be mentioned that in a pioneer work by Prat and co-workers, a 1:2 fullerene:cyclodextrin inclusion complex was prepared that was able to preserve the ability of $\mathrm{C}_{60}$ for singlet oxygen production, despite the efficiency was reduced in about $50 \%$ with respect to free $\mathrm{C}_{60}$, an observation that the authors attributed to fast energy transfer between the fullerene and the host. ${ }^{[59]}$ It is interesting to note that $\mathrm{C}_{70}$ is generally preferred as sensitizer over $\mathrm{C}_{60}$, due to its enhanced visible light absorption, as consequence of the relaxation in the symmetry from $I_{\mathrm{h}}\left(\mathrm{C}_{60}\right)$ to $D_{5 \mathrm{~h}}\left(\mathrm{C}_{70}\right)$ point group symmetries. Accordingly, the transitions that are symmetryforbidden for $\mathrm{C}_{60}$ are allowed for $\mathrm{C}_{70}{ }^{[60]}$ In the case of $\mathrm{C}_{60} @ \mathbf{1}$, the encapsulation of $\mathrm{C}_{60}$ in the metallo-square may reduce the symmetry of the fullerene, therefore increasing the intensity of its low energy absorption bands, which, in turn, produces an enhanced photosensitizing character compared to free $\mathrm{C}_{60}$.

Given the efficient production of ${ }^{1} \mathrm{O}_{2}$ by photosensitizers $\mathrm{C}_{60} @ \mathbf{1}$ and $\mathrm{C}_{70} @ \mathbf{1}$, we decided to study if we could use these two compounds in photocatalytic reactions involving the formation of endoperoxides by cycloaddition of ${ }^{1} \mathrm{O}_{2}$ with dienes. Endoperoxides are often active biological active reagents ${ }^{[61,62]}$ that are used as intermediates in a large number of organic transformations. ${ }^{[63]}$ In addition, the synthesis of natural products is often modeled on possible ${ }^{1} \mathrm{O}_{2}$ biosynthetic routes, thus biomimetic reactions singlet oxygen reactions that use alkene and diene precursors are receiving 
increasing interest during the last few years. ${ }^{[3,11]}$ As a first model reaction, we studied the endoperoxidation of anthracene to analyse the potential use of our photosensitizers in carbon-oxygen bond forming reactions. At this point it is important to mention that there is one very recent example of a metallosupramolecular assembly used as photosensitizer for the lightinduced [4+2] cycloaddition of anthracene with singlet oxygen. ${ }^{[64]}$ Although this report constitutes the only published example of a metallosupramolecular system used for light-induced cycloaddition of ${ }^{1} \mathrm{O}_{2}$, the cage showed to be photolabile and eventually decomposed, therefore providing very limited applicability. We prepared solutions of $0.5 \mathrm{mM}$ of anthracene in deuterated acetonitrile in the presence of different amounts of $\mathrm{C}_{60} @ 1$ and $\mathrm{C}_{70} @ 1$, and irradiated them at 633 (red) and 512 (green) nm with a household RGB LED light $\left(0.07 \mathrm{~mW} / \mathrm{cm}^{2}\right.$ incident power). The reaction could be easily monitored by ${ }^{1} \mathrm{H}$ NMR spectroscopy. Only the reaction carried out under irradiation of green light showed evolution to the formation of 9,10-dihydro-9,10-epidioxyanthracene. The absence of reactivity under red light irradiation can be explained due to the negligible absorption of the two complexes at this wavelength (see Figure S21 in the SI). Figure 2 shows the time-dependent evolution of anthracene conversion. to anthracene endoperoxide in the presence of Rose Bengal, $\mathrm{C}_{60} @ \mathbf{1}$ and $\mathrm{C}_{70} @ \mathbf{1}$. As can be observed, for the reactions carried out with $0.05 \mathrm{mM}$ of the photosensitizers, the reaction is faster when $\mathrm{C}_{70} @ \mathbf{1}$ is used, although $\mathrm{C}_{60} @ \mathbf{1}$ is also very efficient. Under these conditions, the reaction is complete after $65 \mathrm{~min}$ when $\mathrm{C}_{70} @ 1$ is used, while the same concentration of $\mathrm{C}_{60} @ 1$ needs 90 min for completing the reaction. Reducing the concentration of the sensitizer results in a decrease of the reaction rate, although using $5 \times 10^{-4} \mathrm{mM}$ of $\mathrm{C}_{70} @ 1$ 
(which represents a loading of $0.1 \mathrm{~mol} \%$ with respect to the amount of substrate), still produces full conversion in just 4 hours. Interestingly, the activity of the supramolecular sensitizer is maintained constant all over the reaction course, therefore illustrating its stability under the reaction conditions used. The reaction carried out with Rose Bengal showed a higher initial reaction rate, but after $20 \mathrm{~min}$ the reaction proceeded slower, probably due to partial photobleaching of the dye.

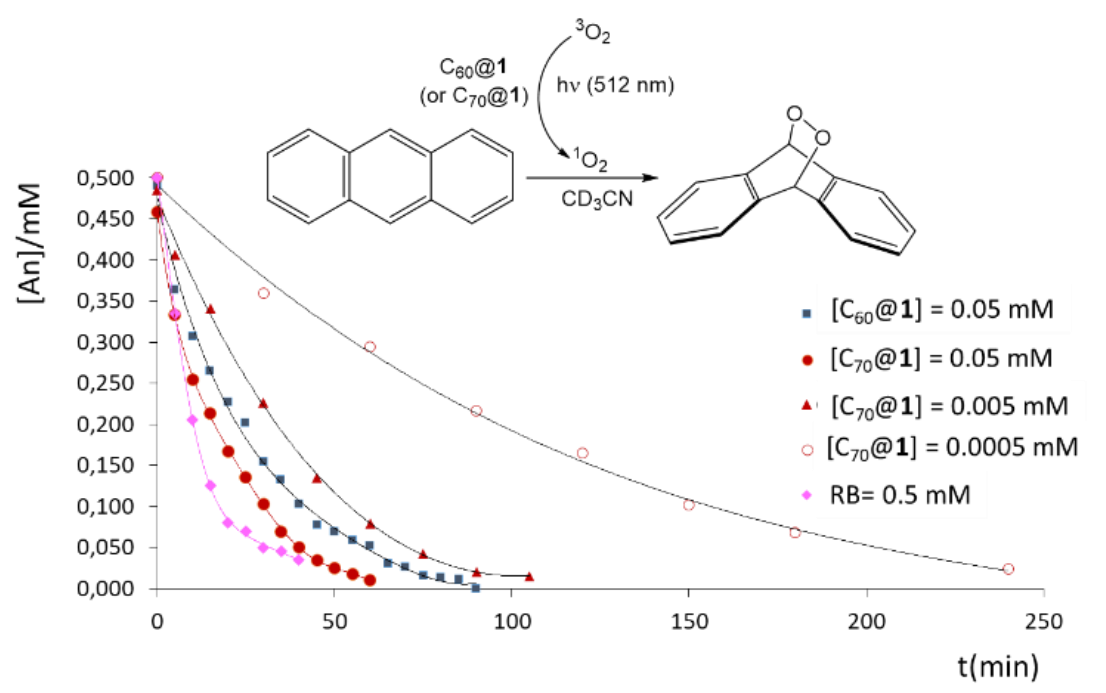

Figure 2. Time-dependent reaction profile of the endoperoxidation of anthracene using Rose Bengal, $\mathrm{C}_{60} @ 1$ and $\mathrm{C}_{70} @ 1$ as photosensitizers. Reactions performed in aeriated $\mathrm{CD}_{3} \mathrm{CN}$ under irradiation at $512 \mathrm{~nm}$ and $0.07 \mathrm{~mW} / \mathrm{cm}^{2}$ incident power. The reactions were monitored by ${ }^{1} \mathrm{H}$ NMR spectroscopy. All reactions using initial concentrations of anthracene of 0.5 $\mathrm{mM}$.

All the reactions proceeded following a pseudo-first order kinetics with respect to the substrate. This allowed us to calculate the reaction rates with all three sensitizers, and to estimate the singlet oxygen quantum yields of $\mathrm{C}_{60} @ \mathbf{1}$ and $\mathrm{C}_{70} @ \mathbf{1}$ from Equation 1. In this equation $\Phi_{\Delta}(\mathrm{RB})$ is the singlet 
oxygen quantum yield for Rose Bengal (0.71), and $\mathrm{W}$ and $\mathrm{W}_{\mathrm{RB}}$ are the reaction rates for the endoperoxidation of anthracene in the presence of the fullerene inclusion complex and Rose Bengal, respectively. By this method the quantum yields for $\mathrm{C}_{60} @ 1$ and $\mathrm{C}_{70} @ 1$ were 0.28 and 0.40, in excellent agreement with the values obtained from Figure 1.

$$
\phi_{\Delta}=\phi_{\Delta}(\mathrm{RB}) \frac{\mathrm{W}}{\mathrm{W}_{\mathrm{RB}}}
$$

The stability of the photosensitizers along the reaction can also be confirmed by monitoring the signals due to the protons of the pyrene moiety of the diNHC ligand of the metallocage, whose integral remained constant with respect to the standard all along the reaction course (see, for example, the spectra shown in Figures S4, S7, S10, S11 and S19 in ESI). This stability of the complexes under the conditions of the reaction is an obvious advantage of these systems compared to the widely used highly conjugated organic photosensitizers, such as Rose Bengal or methylene blue, ${ }^{[9,65,66]}$ for which the production of singlet oxygen destroys conjugation and with it the ability to absorb visible light (photobleaching).

Fullerenes $\mathrm{C}_{60}$ or $\mathrm{C}_{70}$ alone did not produce any anthracene endoperoxide, and $\mathbf{1}$ alone only produced a $2 \%$ conversion after 15 hours. This can be explained by the lack of absorption of visible light by 1 (see Figure S20), and the extremely low solubility of fullerenes in acetonitrile. ${ }^{[67]}$

To explore the substrate scope of our metallosupramolecular photosensitizers, a series of cyclic and acyclic alkenes were subjected to photo-irradiation in the presence of air and $\mathrm{C}_{60} @ \mathbf{1}$ or $\mathrm{C}_{70} @ \mathbf{1}$. For these reactions we used a LED lamp with $3 \mathrm{~mW} / \mathrm{cm}^{2}$ of incident power. The seven 
substrates were chosen to explore their different reactivities and the tolerance to functional groups. Some of these substrates are prone to react with singlet oxygen to produce the corresponding endoperoxides via a photo-induced Diels-Alder reaction in which the oxygen is the dienophile (for substrates $\mathbf{2}$, 3, 4, 5, 7 and 8). Substrates 6 and 8 react through an ene reaction, and yields an allylic hydroperoxide in which the double bond of the substrate has shifted to a position adjacent to the original double bond. The mechanistic aspects of these reactions have been studied in detail. ${ }^{[68]}$ The reactions were performed at room temperature, in an NMR tube filled with a solution of the substrate and the photosensitizer in $\mathrm{CD}_{3} \mathrm{CN}$, so that the evolution of the process could be easily monitored by ${ }^{1} \mathrm{H}$ NMR spectroscopy. Table 1 shows the substrates used and the resulting products, together with the product yields obtained under the reaction conditions used.

The table includes some of the control experiments that we performed when we performed the endoperoxidation of anthracene in the absence of catalysts (entry 1), or in the presence of $\mathrm{C}_{60}$ or $\mathrm{C}_{70}$ alone. As can be observed (entries 1-3), these reactions did not produce any amount of product even after 24 hour of reaction. The Table includes the product yields at the time when full conversion of the substrate is achieved. The two photosensitizers were very active in the endoperoxidation of 9,10-diphenylanthracene (DPA, 3), yielding the corresponding endoperoxide quantitatively [3(O-O)] in just 30 minutes (entries 8 and 9). For the rest of the substrates, $\mathrm{C}_{70} @ 1$ was found more active than $\mathrm{C}_{60} @ \mathbf{1}$. In the endoperoxidation of 1,3-cyclohexadiene (4), C $60 @ 1$ afforded 68\% yield of product in one hour, while $\mathrm{C}_{70} @ 1$ yielded $77 \%$, and quasi-quantitative yield after 24 hours. $\mathrm{C}_{70} @ 1$ facilitated the endoperoxidation of 1,3 -cyclooctadiene yielding $86 \%$ of the endoperoxide 
5(O-O) in 24h, while under the same conditions $\mathrm{C}_{60} @ \mathbf{1}$ afforded a negligible amount of product (compare entries 15 and 17). Similarly, in the reaction of cyclohexene to produce cyclohexenyl hydroperoxide [6(O-O)] $\mathrm{C}_{70} @ \mathbf{1}$ generated the product in 75\% yield after 24 hours, while $\mathrm{C}_{60} @ 1$ only yielded $5 \%$ (compare entries 18 and 19). The cycloaddition of oxygen to 1,4diphenyl butadiene (7) produced the cyclic endoperoxide 7(O-O) in $95 \%$ yield when $\mathrm{C}_{70} @ 1$ was used, but only 72 \% of product was formed for the reaction carried out with $\mathrm{C}_{60} @ 1$ (entries 20 and 21). Finally, the photooxidation of hexamethyl benzene to the epidioxy hydroperoxide 8(OO) was produced in $71 \%$ yield after 2 hours for the reaction carried out with C $70 @ 1$, while the reaction performed with $\mathrm{C}_{60} @ 1$ just generated 7\% of product (entries 22 and 23). This latter reaction consumes two molecules of singlet oxygen, and is known to proceed via a two-step process involving a $[4+2]$ cycloaddition followed by an ene-reaction. ${ }^{[69,70]}$ A point that is worth mentioning is that the yields of the products for the reactions carried out with substrates 5,6 and 8, do not simply reflect the differences in quantum yield production of singlet oxygen by $\mathrm{C}_{60} @ \mathbf{1}$ and $\mathrm{C}_{70} @ \mathbf{1}$. Although we did not make detailed mechanistic studies, it may be possible that the weaker binding of $\mathrm{C}_{60}$ in $\mathrm{C}_{60} @ \mathbf{1}$ (compared to the affinity of $\mathrm{C}_{70}$ in $\left.\mathrm{C}_{70} @ \mathbf{1}\right)^{[43]}$ makes that the fullerene is partially replaced by the substrate or the product in the course of the reaction, and this may justify the unexpected decrease of the reaction yields. 
Table 1. Peroxidation of organic substrates by light-induced cycloaddition of ${ }^{1} \mathrm{O}_{2}$. ${ }^{a}$ Substrate scope.

\begin{tabular}{|c|c|c|c|c|}
\hline Entry & Substrate/Product & Cat. & Time (h) & Yield $(\%)^{\mathrm{b}}$ \\
\hline 1 & & none & 24 & 0 \\
\hline 2 & & $\mathrm{C}_{60}$ & 24 & 0 \\
\hline 3 & & $\mathrm{C}_{70}$ & 24 & 0 \\
\hline 4 & & $\mathrm{C}_{60} @ 1$ & 0.5 & 69 \\
\hline 5 & & $\mathrm{C}_{60} @ \mathbf{1}$ & 1 & $>99$ \\
\hline 6 & & $\mathrm{C}_{70} @ \mathbf{1}$ & 0.5 & 75 \\
\hline 7 & & $\mathrm{C}_{70} @ \mathbf{1}$ & 1 & $>99$ \\
\hline 8 & & $\mathrm{C}_{60} @ 1$ & 0.5 & $>99$ \\
\hline 9 & & $\mathrm{C}_{70} @ \mathbf{1}$ & 0.5 & $>99$ \\
\hline $10^{\mathrm{c}}$ & & $\mathrm{C}_{60} @ 1$ & 1 & 68 \\
\hline $11^{\mathrm{c}}$ & & $\mathrm{C}_{60} @ 1$ & 24 & 81 \\
\hline $12^{\mathrm{c}}$ & $4(0-0)$ & $\mathrm{C}_{70} @ 1$ & 1 & 77 \\
\hline $13^{\mathrm{c}}$ & & $\mathrm{C}_{70} @ 1$ & 24 & 92 \\
\hline $14^{\mathrm{c}}$ & & $\mathrm{C}_{60} @ 1$ & 1 & 0 \\
\hline $15^{\mathrm{c}}$ & & $\mathrm{C}_{60} @ 1$ & 24 & 5 \\
\hline $16^{\mathrm{c}}$ & & $\mathrm{C}_{70} @ 1$ & 1 & 10 \\
\hline $17^{\mathrm{c}}$ & & $\mathrm{C}_{70} @ 1$ & 24 & 86 \\
\hline $18^{\mathrm{c}}$ & & $\mathrm{C}_{60} @ 1$ & 24 & 5 \\
\hline $19^{\mathrm{c}}$ & 6 & $\mathrm{C}_{70} @ 1$ & 24 & 82 \\
\hline $20^{\mathrm{d}}$ & & $\mathrm{C}_{60} @ 1$ & 12 & 72 \\
\hline $21^{\mathrm{d}}$ & $7(0$ & $\mathrm{C}_{70} @ \mathbf{1}$ & 12 & 95 \\
\hline
\end{tabular}




$23^{\mathrm{d}}$

We find important to point out that many of the products obtained from these reactions are important reaction intermediates that have been used for the synthesis of several natural products and commercially valuable materials, therefore their high yielding preparation constitutes a matter of great interest. For example, $\mathbf{4}(\mathrm{O}-\mathrm{O})$ is the first reaction intermediate used in the preparation of teucrolivin $\mathrm{A}^{[71]}$ and toxocarol. ${ }^{[72]}$ The cyclooctene endoperoxide 5(O-O) has recently been used for the preparation of 1,2-diaminocyclooctanediols ${ }^{[73]}$ and 4-hydroxyenones, ${ }^{[74]}$ and for the total synthesis of (+)-dubiusamine A (1). ${ }^{[75]}$ Cyclohexene hydroperoxide (6(O-O)) is a key starting reagent in the production of nylon- 6 and nylon- 6,6 polyamides. ${ }^{[76]}$ The endoperoxide $7(\mathbf{O}$ O) is an intermediate in the biosynthetically inspired route to diphenyl furan and furan fatty acids, ${ }^{[77]}$ and for the asymmetric synthesis of fused butyrolactones. ${ }^{[78]}$ 


\section{Conclusions}

In conclusion, by taking advantage of the excellent spin-converting properties of fullerenes, we used our fullerene-containing host:guest complexes as photosensitizers for the generation of singlet $\mathrm{O}_{2}$. Both $\mathrm{C}_{60} @ 1$ or $\mathrm{C}_{70} @ 1$ were found to be very effective photosensitizers for the peroxidation of a broad variety of cyclic and acyclic alkenes under air atmosphere. While supramolecular photochemistry has recently been highlighted as a potential powerful synthetic tool,[79] the examples in which supramolecular assemblies are used for promoting photocycloadditions are restricted to their participation as hosts or templates for facilitating the solubilization of the organic substrates in water. To the best of our knowledge, this is the first time that a host:guest supramolecular assembly is used for the peroxidation a variety of organic substrates. Our findings go beyond the results that we describe in this work, because they underline the possibility that other fullerene-containing host-guest supramolecular systems have the potential to be used for similar photocatalytic reactions, therefore opening a venue for future research. Also important is the potential implications of this study in the use of fullerene-encapsulated supramolecular systems in the development of agents for clinical photodynamic therapy treatment (PDT). Research in these directions is currently being developed in our laboratory. 


\section{Experimental section}

\section{General Comments}

The preparation of the palladium-cornered metallo-square 1 was performed according to the literature method.[43] Anhydrous solvents were dried using the Solvent Purification System (SPS M BRAUN) or purchased and degassed prior to use. All other reagents were used as received from commercial suppliers. NMR spectra were recorded on a Varian Innova 500 $\mathrm{MHz}$ or on a Bruker 400/300MHz. NMR spectra were recorded at room temperature with $\mathrm{CD}_{3} \mathrm{CN}$ as solvent. All values of the chemical shift are in ppm regarding the $\delta$-scale. UV/Visible absorption spectra were recorded on a Varian Cary 300 BIO spectrophotometer using acetonitrile under ambient conditions. Emission spectra were recorded on a modular Horiba FluoroLog3 spectrofluorometer employing degassed acetonitrile. As an example, the following paragraph describes the general procedure used for the endoperoxidation of anthracene. The details about the photocatalytic reactions carried out with all other substrates are given in the Supplementary Information.

Photocatalytic Endoperoxidation of Anthracene with Fullerene@1

All experiments were performed in NMR tubes with $\mathrm{CD}_{3} \mathrm{CN}$ and a previous sonication for 12 hours of host solution (complex 1) and the respective fullerene. The samples were irradiated with green light $(\lambda=512 \mathrm{~nm})$, with a $3.5 \mathrm{~W}$ household RGB-LED light $\left(0.07 \mathrm{~mW} / \mathrm{cm}^{2}\right.$ incident power $)$. The initial concentration of anthracene concentration was $0.5 \mathrm{mM}$ in all experiments, while Fullerene@1 concentration was set to $0.05 \mathrm{mM}$ (10 mol\% cat), 0.005 $\mathrm{mM}(1 \mathrm{~mol} \%$ cat $)$ and $0.0005 \mathrm{mM}(0.1 \mathrm{~mol} \%$ cat $)$. The experiments were 
carried out placing the NMR tube at $10 \mathrm{~cm}$ of the light beam, under the exclusion from other light sources by a black box. NMR sample was protected from ambient light between the measurements. The advance of the reaction was monitored by ${ }^{1} \mathrm{H}$ NMR spectroscopy.

\section{Acknowledgements}

We gratefully acknowledge financial support from the Universitat Jaume I (UJI-B2017-07). V. M.-A. thanks the Generalitat Valenciana for a $\mathrm{PhD}$ fellowship We are grateful to the Serveis Centrals d'Instrumentació Científica (SCIC-UJI) for providing with spectroscopic facilities.

Keywords: supramolecular coordination cage (SSC) • N-heterocyclic carbene $\bullet$ Host-guest chemistry $\bullet$ fullerene $\bullet$ self-assembly

\section{TOC:}

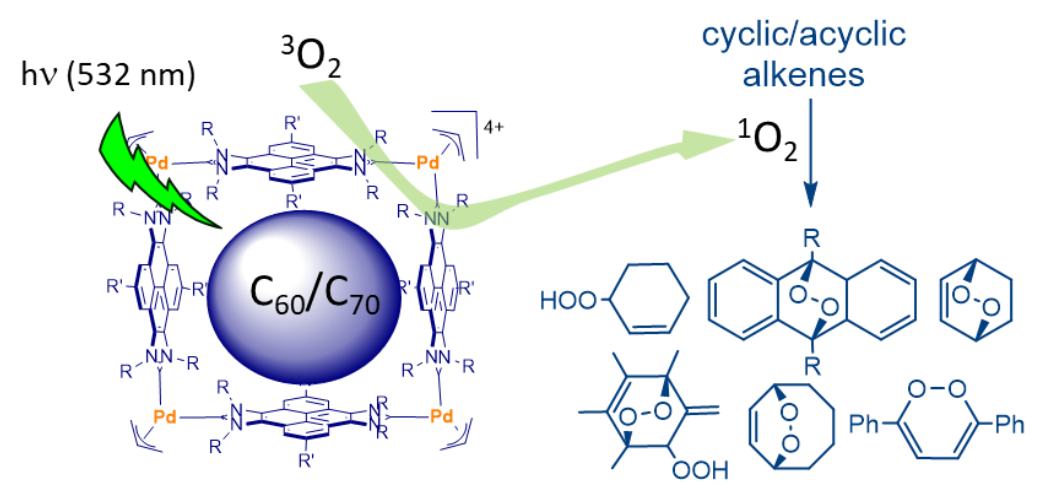




\section{References}

1. Hoffmann, N., Photochemical reactions as key steps in organic synthesis. Chemical Reviews, 2008. 108(3): p. 1052-1103.

2. Singleton, D.A., et al., Mechanism of ene reactions of singlet oxygen. A two-step no-intermediate mechanism. Journal of the American Chemical Society, 2003. 125(5): p. 1319-1328.

3. Di Mascio, P., et al., Singlet Molecular Oxygen Reactions with Nucleic Acids, Lipids, and Proteins. Chemical Reviews, 2019. 119(3): p. 2043-2086.

4. Clennan, E.L. and A. Pace, Advances in singlet oxygen chemistry. Tetrahedron, 2005. 61(28): p. 6665-6691.

5. Aubry, J.M., et al., Reversible binding of oxygen to aromatic compounds. Accounts of Chemical Research, 2003. 36(9): p. 668675.

6. Dolmans, D., D. Fukumura, and R.K. Jain, Photodynamic therapy for cancer. Nature Reviews Cancer, 2003. 3(5): p. 380-387.

7. Ogilby, P.R., Singlet oxygen: there is indeed something new under the sun. Chemical Society Reviews, 2010. 39(8): p. 3181-3209.

8. Lovell, J.F., et al., Activatable Photosensitizers for Imaging and Therapy. Chemical Reviews, 2010. 110(5): p. 2839-2857.

9. DeRosa, M.C. and R.J. Crutchley, Photosensitized singlet oxygen and its applications. Coordination Chemistry Reviews, 2002. 233: p. 351371.

10. Yu, G.C., et al., A discrete organoplatinum(II) metallacage as a multimodality theranostic platform for cancer photochemotherapy. Nature Communications, 2018. 9.

11. Ghogare, A.A. and A. Greer, Using Singlet Oxygen to Synthesize Natural Products and Drugs. Chemical Reviews, 2016. 116(17): p. 9994-10034.

12. Nosaka, Y. and A.Y. Nosaka, Generation and Detection of Reactive Oxygen Species in Photocatalysis. Chemical Reviews, 2017. 117(17): p. 11302-11336.

13. Greer, A., Christopher Foote's discovery of the role of singlet oxygen 
O-1(2) ((1)Delta(g)) in photosensitized oxidation reactions. Accounts of Chemical Research, 2006. 39(11): p. 797-804.

14. Vankayala, R., et al., Metal Nanoparticles Sensitize the Formation of Singlet Oxygen. Angewandte Chemie-International Edition, 2011. 50(45): p. 10640-10644.

15. Xu, S., et al., Selective Oxidation of 5-Hydroxymethylfurfural to 2,5Furandicarboxylic Acid Using $\mathrm{O}-2$ and a Photocatalyst of Cothioporphyrazine Bonded to g-C3N4. Journal of the American Chemical Society, 2017. 139(41): p. 14775-14782.

16. Sagadevan, A., K.C. Hwang, and M.D. Su, Singlet oxygen-mediated selective $\mathrm{C}-\mathrm{H}$ bond hydroperoxidation of ethereal hydrocarbons. Nature Communications, 2017. 8.

17. de Souza, J.M., et al., Continuous Endoperoxidation of Conjugated Dienes and Subsequent Rearrangements Leading to C-H Oxidized Synthons. Journal of Organic Chemistry, 2018. 83(15): p. 7574-7585.

18. Schweitzer, C. and R. Schmidt, Physical mechanisms of generation and deactivation of singlet oxygen. Chemical Reviews, 2003. 103(5): p. 1685-1757.

19. You, Y., Chemical tools for the generation and detection of singlet oxygen. Organic \& Biomolecular Chemistry, 2018. 16(22): p. 40444060 .

20. Ishii, K., Functional singlet oxygen generators based on phthalocyanines. Coordination Chemistry Reviews, 2012. 256(1516): p. 1556-1568.

21. Yamakoshi, Y., et al., Active oxygen species generated from photoexcited fullerene $(C-60)$ as potential medicines: O-2(-center dot) versus $O-1(2)$. Journal of the American Chemical Society, 2003. 125(42): p. 12803-12809.

22. Prat, F., et al., Triplet-state properties and singlet oxygen generation in a homologous series of functionalized fullerene derivatives. Journal of Physical Chemistry A, 1999. 103(36): p. 7230-7235.

23. Nakamura, Y., et al., Photoreactions between 60 fullerene and various aromatic tertiary amines. Journal of Organic Chemistry, 2005. 70(21): p. 8472-8477.

24. Luo, C., et al., Substituent and solvent effects on photoexcited states 
of functionalized fullerene 60. Journal of the Chemical SocietyFaraday Transactions, 1998. 94(4): p. 527-532.

25. Marcus, Y., Solubilities of buckminsterfullerene and sulfur hexafluoride in various solvents. Journal of Physical Chemistry B, 1997. 101(42): p. 8617-8623.

26. Priyadarsini, K.I., et al., Identity of transients formed from chlorinated fullerenes in organic solvents: A pulse radiolysis study. Journal of Physical Chemistry, 1996. 100(2): p. 501-506.

27. Anderson, J.L., et al., Photophysical Characterization and Singlet Oxygen Yield of a Dihydrofullerene. Journal of the American Chemical Society, 1994. 116(21): p. 9763-9764.

28. Malikova, R.N., et al., Fullerene C-60 Derivatives as Efficient Sensitizers of Oxidation under the Mild Conditions of Atmospheric Air. Russian Journal of General Chemistry, 2017. 87(10): p. 24972499.

29. Yamamoto, M., et al., A Ruthenium Complex-Porphyrin-FullereneLinked Molecular Pentad as an Integrative Photosynthetic Model. Angewandte Chemie-International Edition, 2017. 56(12): p. 33293333.

30. Wolf, M., et al., Rigid, Branched Porphyrin Antennas: Control over Cascades of Unidirectional Energy Funneling and Charge Transfer. Journal of the American Chemical Society, 2017. 139(34): p. 1177911788.

31. Ke, X.S., et al., Flattened Calixarene-like Cyclic BODIPY Array: A New Photosynthetic Antenna Model. Journal of the American Chemical Society, 2017. 139(39): p. 13950-13956.

32. Favereau, L., et al., A Molecular Tetrad That Generates a HighEnergy Charge-Separated State by Mimicking the Photosynthetic ZScheme. Journal of the American Chemical Society, 2016. 138(11): p. 3752-3760.

33. Kc, C.B., G.N. Lim, and F. D'Souza, Charge Separation in Graphene-Decorated Multimodular Tris(pyrene)-SubphthalocyanineFullerene Donor-Acceptor Hybrids. Angewandte ChemieInternational Edition, 2015. 54(17): p. 5088-5092.

34. Guldi, D.M., Fullerene-porphyrin architectures; photosynthetic 
antenna and reaction center models. Chemical Society Reviews, 2002. 31(1): p. 22-36.

35. Gust, D., T.A. Moore, and A.L. Moore, Mimicking photosynthetic solar energy transduction. Accounts of Chemical Research, 2001. 34(1): p. 40-48.

36. Kc, C.B. and F. D'Souza, Design and photochemical study of supramolecular donor-acceptor systems assembled via metal-ligand axial coordination. Coordination Chemistry Reviews, 2016. 322: p. 104-141.

37. Kawase, T. and H. Kurata, Ball-, bowl-, and belt-shaped conjugated systems and their complexing abilities: Exploration of the concaveconvex pi-pi interaction. Chemical Reviews, 2006. 106(12): p. 52505273.

38. Garcia-Simon, C., M. Costas, and X. Ribas, Metallosupramolecular receptors for fullerene binding and release. Chemical Society Reviews, 2016. 45(1): p. 40-62.

39. Sygula, A., Corannulene-Adorned Molecular Receptors for Fullerenes Utilizing the pi-pi Stacking of Curved-Surface Conjugated Carbon Networks. Design, Synthesis and Testing. Synlett, 2016. 27(14): p. 2070-2080.

40. Makha, M., et al., Structural diversity of host-guest and intercalation complexes of fullerene C-60. European Journal of Inorganic Chemistry, 2006(3): p. 507-517.

41. Mejuto, C., et al., Self-Assembly of Di-N-Heterocyclic Carbene-GoldAdorned Corannulenes on C-60. Chemistry-a European Journal, 2017. 23(44): p. 10644-10651.

42. Martinez-Agramunt, V., D. Gusev, and E. Peris, A shape-adaptable organometallic supramolecular coordination cage for the encapsulation of fullerenes. Chemistry-a European Journal, 2018. 24(55): p. 14802-14807.

43. Martínez-Agramunt, V., et al., A size-flexible organometallic box for the encapsulation of fullerenes. Angewandte Chemie, International Edition, 2019. 58(17): p. 5682-5686.

44. Cook, T.R. and P.J. Stang, Recent Developments in the Preparation and Chemistry of Metallacycles and Metallacages via Coordination. 
Chemical Reviews, 2015. 115(15): p. 7001-7045.

45. Cook, T.R., Y.-R. Zheng, and P.J. Stang, Metal-Organic Frameworks and Self-Assembled Supramolecular Coordination Complexes: Comparing and Contrasting the Design, Synthesis, and Functionality of Metal-Organic Materials. Chemical Reviews, 2013. 113(1): p. 734-777.

46. Gianneschi, N.C., M.S. Masar, and C.A. Mirkin, Development of a coordination chemistry-based approach for functional supramolecular structures. Accounts of Chemical Research, 2005. 38(11): p. 825-837.

47. Caulder, D.L. and K.N. Raymond, Supermolecules by design. Accounts of Chemical Research, 1999. 32(11): p. 975-982.

48. Chakrabarty, R., P.S. Mukherjee, and P.J. Stang, Supramolecular Coordination: Self-Assembly of Finite Two- and Three-Dimensional Ensembles. Chemical Reviews, 2011. 111(11): p. 6810-6918.

49. Castilla, A.M., W.J. Ramsay, and J.R. Nitschke, Stereochemistry in Subcomponent Self-Assembly. Accounts of Chemical Research, 2014. 47(7): p. 2063-2073.

50. McConnell, A.J., et al., Stimuli-Responsive Metal-Ligand Assemblies. Chemical Reviews, 2015. 115(15): p. 7729-7793.

51. Fujita, M. and K. Ogura, Transition-metal-directed assembly of welldefined organic architectures possessing large voids: From macrocycles to 2 catenanes. Coordination Chemistry Reviews, 1996. 148: p. 249-264.

52. Fujita, M., Metal-directed self-assembly of two- and threedimensional synthetic receptors. Chemical Society Reviews, 1998. 27(6): p. 417-425.

53. Han, M., D.M. Engelhard, and G.H. Clever, Self-assembled coordination cages based on banana-shaped ligands. Chemical Society Reviews, 2014. 43(6): p. 1848-1860.

54. Gan, M.M., et al., Preparation and Post-Assembly Modification of Metallosupramolecular Assemblies from Poly(N-Heterocyclic Carbene) Ligands. Chemical Reviews, 2018. 118(19): p. 9587-9641.

55. Sinha, N. and F.E. Hahn, Metallosupramolecular Architectures Obtained from PoIy-N-heterocyclic Carbene Ligands. Accounts of 
Chemical Research, 2017. 50(9): p. 2167-2184.

56. Ortiz, M.J., et al., Synthesis and functionalization of new polyhalogenated BODIPY dyes. Study of their photophysical properties and singlet oxygen generation. Tetrahedron, 2012. 68(4): p. 1153-1162.

57. Arbogast, J.W. and C.S. Foote, PHOTOPHYSICAL PROPERTIES OF C-70. Journal of the American Chemical Society, 1991. 113(23): p. 8886-8889.

58. Arbogast, J.W., et al., PHOTOPHYSICAL PROPERTIES OF C60. Journal of Physical Chemistry, 1991. 95(1): p. 11-12.

59. Prat, F., et al., $C$-60 Fullerene-based materials as singlet oxygen $O$ 2((1)Delta $(g))$ photosensitizers: a time-resolved near-IR luminescence and optoacoustic study. Physical Chemistry Chemical Physics, 2001. 3(9): p. 1638-1643.

60. Hare, J.P., H.W. Kroto, and R. Taylor, Preparation and UV visible spectra of fullerenes C60 and C70. Chemical Physics Letters, 1991. 177(4-5): p. 394-398.

61. Meshnick, S.R., T.E. Taylor, and S. Kamchonwongpaisan, Artemisinin and the antimalarial endoperoxides: From herbal remedy to targeted chemotherapy. Microbiol. Rev., 1996. 60(2): p. 301-315.

62. Moncada, S. and J.R. Vane, Pharmacology and Endogenous Roles of Prostaglandin Endoperoxides, Thromboxane-A2, and Prostacylin. Pharmacol. Rev., 1978. 30(3): p. 293-331.

63. Balci, M., Bicyclic Endoperoxides and Synthetic Applications. Chemical Reviews, 1981. 81(1): p. 91-108.

64. Preston, D., et al., A Nona-nuclear Heterometallic Pd3Pt6 "Donut"Shaped Cage: Molecular Recognition and Photocatalysis. Angewandte Chemie-International Edition, 2018. 57(28): p. 86598663.

65. Linden, S.M. and D.C. Neckers, BLEACHING STUDIES OF ROSEBENGAL ONIUM SALTS. Journal of the American Chemical Society, 1988. 110(4): p. 1257-1260.

66. Chesneau, E. and D.C. Neckers, ELECTRON-TRANSFER SENSITIZED PHOTOBLEACHING OF ROSE-BENGAL INDUCED 
BY TRIPLET BENZOPHENONES. Journal of Photochemistry and Photobiology a-Chemistry, 1988. 42(2-3): p. 269-281.

67. Semenov, K.N., et al., Solubility of Light Fullerenes in Organic Solvents. Journal of Chemical and Engineering Data, 2010. 55(1): p. 13-36.

68. Frimer, A.A., REACTION OF SINGLET OXYGEN WITH OLEFINS QUESTION OF MECHANISM. Chemical Reviews, 1979. 79(5): p. 359-387.

69. van den Heuvel, C.J.M., et al., The photo-oxidation of hexamethylbenzene and pentamethylbenzene by singlet oxygen. Recueil des Travaux Chimiques des Pays-Bas, 1980. 99(9): p. 275278.

70. Zadok, E., et al., Reactions of Dimethylbenzene, Trimethylbenzene, and Hexamethylbenzene with $O(P-3)$ Atoms in Liquid and on Adsorb Phases. Journal of the American Chemical Society, 1985. 107(8): p. 2489-2494.

71. Arns, S. and L. Barriault, Concise synthesis of the neo-clerodane skeleton of teucrolivin a using a pericyclic reaction cascade. Journal of Organic Chemistry, 2006. 71(5): p. 1809-1816.

72. Valente, P., et al., Synthesis and Chemistry of 2,3-Dioxabicyclo 2.2.2 octane-5,6-diols. Journal of Organic Chemistry, 2009. 74(1): p. 274282.

73. Zozik, Y., E. Salamci, and A. Kilic, Synthesis of eight-membered aminocyclitol analogues. Tetrahedron Letters, 2017. 58(52): p. 48224826.

74. Staben, S.T., L.H. Xin, and F.D. Toste, Enantioselective synthesis of gamma-hydroxyenones by chiral base-catalyzed Kornblum DeLaMare rearrangement. Journal of the American Chemical Society, 2006. 128(39): p. 12658-12659.

75. Kawasumi, M. and Y. Iwabuchi, Concise Entry to Chiral 5-(4Hydroxybutyl)-2(5H)-furanone via HTIB-Mediated Novel Oxidative Fragmentation: Formal Total Synthesis of (+)-Dubiusamine A. Organic Letters, 2013. 15(7): p. 1788-1790.

76. Hereijgers, B.P.C., R.F. Parton, and B.M. Weckhuysen, Cyclohexene Epoxidation with Cyclohexyl Hydroperoxide: A Catalytic Route to 
Largely Increase Oxygenate Yield from Cyclohexane Oxidation. Acs Catalysis, 2011. 1(10): p. 1183-1192.

77. Lee, R.J., et al., A biosynthetically inspired route to substituted furans using the Appel reaction: total synthesis of the furan fatty acid F5. Chemical Communications, 2017. 53(47): p. 6327-6330.

78. Priest, J., et al., An Asymmetric Synthesis of trans-Fused Butyrolactones from Endoperoxides. Journal of Organic Chemistry, 2013. 78(7): p. 3476-3481.

79. Ramamurthy, V. and J. Sivaguru, Supramolecular Photochemistry as a Potential Synthetic Tool: Photocycloaddition. Chemical Reviews, 2016. 116(17): p. 9914-9993. 


\section{ChemComm}

\section{(A) Check for updates}

Cite this: Chem. Commun., 2019, 55,14972

Received 4th November 2019, Accepted 19th November 2019

DOI: $10.1039 /$ c9cc08595e

rsc.li/chemcomm

\section{A palladium-hinged organometallic square with a perfect-sized cavity for the encapsulation of three heteroguests +}

\author{
Victor Martinez-Agramunt and Eduardo Peris (C)*
}

\begin{abstract}
A nanometer-sized tetrapalladium metallosquare with a pyrenebisimidazolylidene ligand was found to display a perfect-sized cavity for the encapsulation of three heteroguests, enabling the formation of quintuple $D-A-D-A-D$ stacks. The encapsulating properties of the metallosquare are clearly determined by the presence of the pyrene panels, which endow the metallosquare with a three-dimensional shape, and also behave as effective antennae for $\pi$-stacking interactions.
\end{abstract}

Supramolecular systems with cavities, capable of hosting molecular guests, have received great attention due to their potential applications as flasks for chemical reactions, ${ }^{1}$ containers for reactive chemical species, ${ }^{2}$ hosts for aromatic stacks, ${ }^{3}$ as sensors, ${ }^{4}$ and as transport vehicles for molecules with medical properties. ${ }^{5}$ While many supramolecular systems are able to encapsulate single guests, the binding of multiple guests by a single receptor can lead to new modes of host-guest interactions that may be translated into new applications. ${ }^{6}$ Enabling artificial systems in which the binding of one substrate cooperatively affects the binding of subsequent guest molecules, and promotes allosteric communication between all components, is one of the greatest challenges of supramolecular chemistry. In addition, supramolecular entities with cavities of appropriate size can be used to approach substrates closer by encapsulation, so that their mutual interaction can exhibit unusual or non-classical physical properties. ${ }^{3 c}$ In this regard, the preparation of receptors capable of intercalating multiple stacks is very challenging, ${ }^{3 b}$ because enabling discrete $\pi$-stacks can facilitate the study of the charge transport at the molecular level, a long-standing issue for the design of nanoscale electronic devices. ${ }^{3 a, d, 7}$

In general, the most efficient tool for enabling discrete aromatic stacks in solution is the use of organic-pillared co-facial

Institute of Advanced Materials (INAM), Universitat Jaume $I$, Av. Vicente Sos Baynat s/n, 12071-Castellón, Spain. E-mail: eperis@ujies

$\dagger$ Electronic supplementary information (ESI) available: Experimental procedure, and NMR, UV-vis and mass spectra. All titration data and determination of binding constants. See DOI: 10.1039/c9cc08595e

coordination cages, normally displaying a trigonal prismatic shape,,$^{3 a, d, 7}$ in which the number of planar guest molecules depends exclusively on the cavity height, which is determined by the pillar length. Inspired by the pioneering works of Hahn and co-workers that described the preparation of a series of square-like and rectangle-like metallo-cages using a benzo-bisimidazolylidene ligand, ${ }^{8}$ we recently described two nickel-hinged molecular rectangles that were used for the encapsulation of polycyclic aromatic hydrocarbons (PAHs) (Scheme 1). ${ }^{9}$ These molecular receptors were based on a pyrene-bis-imidazolylidene ligand, in combination with pyrazine $\left([1]^{4+}\right)$ or $4,4^{\prime}$-bipyridine $\left([2]^{4+}\right)$. Due to their different dimensions, the rectangle with the pyrazine pillars was able to accommodate only one PAH molecule, while the one with the longer bipyridine was capable of hosting up to two guest molecules (Scheme 1). By using the same pyrenebis-imidazolylidene ligand, we also described a palladiumcornered metallosquare $[3]^{4+}$, whose cavity was suitable for the encapsulation of fullerenes. ${ }^{10}$ This metallosquare displays a metal-to-metal distance of $13 \hat{\mathrm{A}}$, approximately four times the distance for an effective $\pi-\pi$ stacking interaction, and therefore

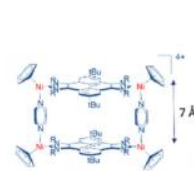

$[1]^{4 *}$
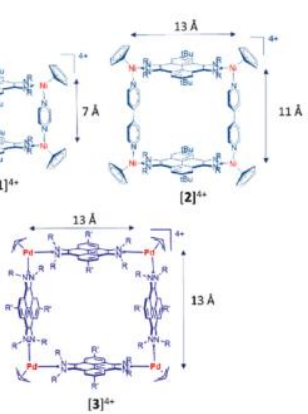

Scheme 1 Metallorectangles $\left([1]^{4+}\right.$ and $\left.[2]^{4+}\right)$ and metallosquare $[3]^{4+}$ previously described in our group. 
8. Article 5

Chem.Commun., 55 (2019) 14972-14975

\title{
A palladium-hinged organometallic square with a perfect-sized cavity for the encapsulation of three heteroguests
}

Víctor Martínez-Agramunt and Eduardo Peris*

${ }^{a}$ Institute of Advanced Materials (INAM). Centro de Innovación en Química Avanzada (ORFEO-CINQA). Av. Vicente Sos Baynat s/n. Universitat Jaume I, 12071 Castellón. Spain.

\begin{abstract}
A nanometer-sized tetrapalladium metallosquare with a pyrenebisimidazolylidene ligand was found to display a perfect-sized cavity for the encapsulation of three heteroguests, enabling the formation of quintuple DA-D-A-D stacks. The encapsulating properties of the metallosquare are clearly determined by the presence of the pyrene panels, which endow the metallosquare a three-dimensional shape, and also behaves as an effective antenna for for $\pi$-stacking interactions.
\end{abstract}




\section{Comunication}

Supramolecular systems with cavities, capable of hosting molecular guests have received great attention due to their potential applications as flasks for chemical reactions, ${ }^{[1-5]}$ containers for reactive chemical species, ${ }^{[6,}$ 7] hosts for aromatic stacks, ${ }^{[8-11]}$ sensors, ${ }^{[12-14]}$ and as transport vehicles for molecules with medical properties. ${ }^{[15-18]}$ While many supramolecular systems are able to encapsulate single guests, the binding of multiple guests by a single receptor can lead to new modes of host-guest interactions that may be translated into new applications. ${ }^{[19]}$ Enabling artificial systems in which the binding of one substrate cooperatively affects the binding of subsequent guest molecules, and promotes allosteric communication between all components, is one of the greatest challenges of supramolecular chemistry. In addition, supramolecular entities with cavities of the appropriate size can be used to approach substrates closer by encapsulation, so that their mutual interaction can exhibit unusual or non-classical physical properties. ${ }^{[10]}$ For example, receptors capable of intercalating multiple stacks are very challenging, ${ }^{[9]}$ because enabling discrete $\pi$-stacks can facilitate the study of the charge transport at the molecular level, a long-standing issue for the design of nanoscale electronic devices. ${ }^{[8,11,20-23]}$

In general, the most efficient tool for enabling discrete aromatic stacks in solution is the use of organic-pillared co-facial coordination cages, normally displaying a trigonal prismatic shape, ${ }^{[8,11,20-23]}$ in which the number of planar guest molecules depends exclusively on the cavity 
height, which is determined by the pillar length. Inspired by the pioneering works by Hahn and co-workers that described the preparation of a series of square-like and rectangle like metallo-cages using a benzo-bis-imidazolylidene ligand, ${ }^{[24,25]}$ we recently described two nickel-hinged molecular rectangles that were used for the encapsulation of polycyclic aromatic hydrocarbons (PAHs) (Scheme 1). ${ }^{[26]}$ These molecular receptors, were based on a pyrene-bisimidazolylidene ligand, in combination with pyrazine $\left([1]^{4+}\right)$ or $4,4^{\prime}$ bipyridine $\left([2]^{4+}\right)$. Due to their different dimensions, the rectangle with the pyrazine pillars was able to accommodate only one PAH molecule, while the one with the longer by-pyridine, was capable of hosting up to two guest molecules (Scheme 1).

By using the same pyrene-bis-imidazolylidene ligand, we also described a palladium-cornered metallosquare $[3]^{4+}$, whose cavity was suitable for the encapsulation of fullerenes. ${ }^{[27,28]}$ This metallosquare displays a metal-to-metal distance of $13 \AA$, approximately four times the distance for an effective $\pi-\pi$ stacking interaction, and therefore is expected to be suitable for inclusion of up to three polyaromatic guests. With these precedents in hand, in this work we examined the hostguest chemistry properties of the metallosquare $\mathbf{3}$ with a series of PAHs. In addition, we also studied the ability of $\mathbf{3}$ to accommodate two different aromatic guests. As will be discussed, the $\pi$-stacks are ordered in donor-acceptor-donor-acceptor-donor (D-A-D-A-D) arrays, with the electron-rich pyrene fragments of the di-NHC ligand as bookend donors. 


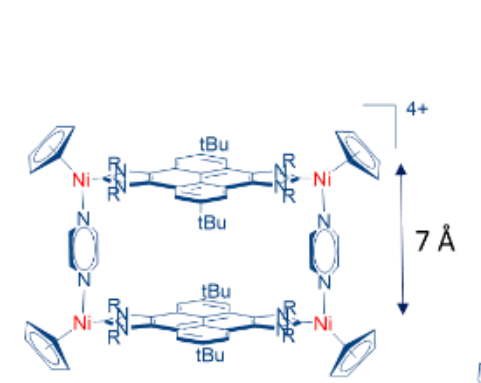

$[1]^{4+}$

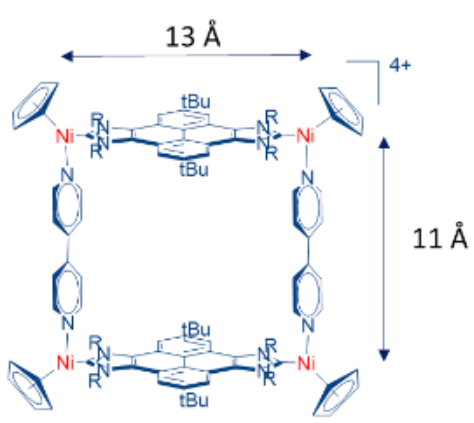

$[2]^{4+}$

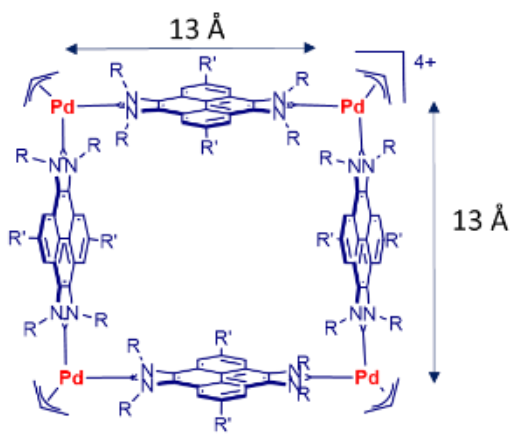

[3] $]^{4+}$

Scheme 1. Metallorectangles $\left([\mathbf{1}]^{4+}\right.$ and $\left.[2]^{4+}\right)$ and metallosquare $[3]^{4+}$ previously described in our group

We first tested the molecular square $[3]\left(\mathrm{BF}_{4}\right)_{4}$ for the recognition of pyrene and triphenylene. The host-guest properties of the square were studied by ${ }^{1}$ HNMR spectroscopy, by monitoring the changes produced in the chemical shifts of the signals due to the ligands of the metal complex upon addition of solutions with the two aromatic guests. The experiments were carried out in $\mathrm{CD}_{3} \mathrm{CN}$, at room temperature and at a constant concentration of host, typically $1 \mathrm{mM}$. For both titrations, the addition of the solutions of the guests produced important perturbations in the chemical shifts of the signals of the host, indicating the formation of inclusion complexes that showed fast 
kinetics on the NMR timescale. As an illustrative example, Figure 1 shows the aromatic region of the ${ }^{1} \mathrm{H}$ NMR spectra acquired during the titration of [3] $\left(\mathrm{BF}_{4}\right)_{4}$ with pyrene. The sequence of spectra shows how the resonances due to the protons of the pyrene fragment of the pyrene-bisimidazolylidene ligands of the molecular square are upfield shifted upon the addition of the pyrene solution. The determination of the association constant was performed by nonlinear analysis of the titration data. The binding isotherm resulting from plotting the variation of the chemical shift with the guest/host ratio was bet fitted to a 1:2 host:guest stoichiometry, as a result from the analysis of the distribution of the residuals compared to a 1:1 stoichiometry. The analysis of the ${ }^{1} \mathrm{H}$ NMR spectra also allowed determining the host:guest association constants for the titrations performed with pyrene $\left(\mathrm{K}_{11}=220(20)\right.$ $\left.\mathrm{M}^{-1} ; \mathrm{K}_{12}=46(3) \mathrm{M}^{-1}\right)$ and triphenylene $\left(\mathrm{K}_{11}=280(30) \mathrm{M}^{-1} ; \mathrm{K}_{12}=52(4) \mathrm{M}^{-1}\right)$.

The association constants that we obtained for the three PAH guests under study were in the order pyrene $<$ triphenylene $<<$ coronene, indicating that as the guest becomes more $\pi$-electron-rich, the $\pi-\pi$ stacking interaction between the guest and the host becomes more effective, and therefore the binding constant becomes larger. ${ }^{\text {[26, 29-31] }}$ The analysis of the binding affinity of coronene could not be performed by ${ }^{1} \mathrm{H}$ NMR titrations due to the low solubility of this guest in $\mathrm{CD}_{3} \mathrm{CN}$. Therefore, for the determination of the binding constant with this PAH molecule, we decided to perform Uv-Vis titrations. The $\mathrm{Uv}-\mathrm{Vis}$ spectrum of $[3]\left(\mathrm{BF}_{4}\right)_{4}$ shows the bands due to the absorption of the pyrene moieties of the bridging ligands of the complex between 300 and $370 \mathrm{~nm}$. Upon addition of coronene, the intensities of the 
bands at 323, 334, 339 and $345 \mathrm{~nm}$ increase, while the band at $354 \mathrm{~nm}$ becomes less intense, thus showing a clear isosbestic point at $348 \mathrm{~nm}$ (see Figure 2).

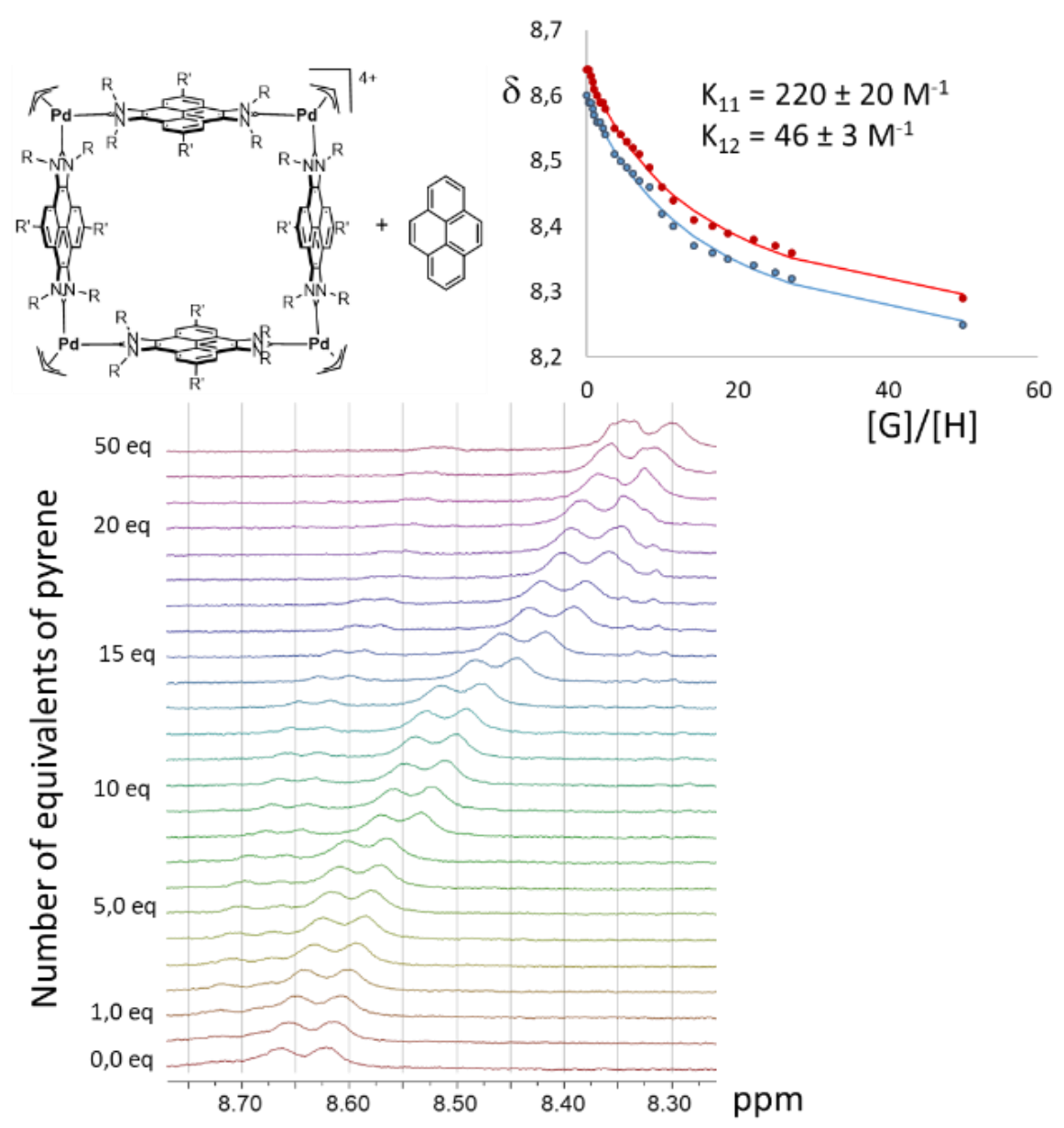

Figure 2. Uv-Vis. spectra acquired during the titration of $[3]\left(\mathrm{BF}_{4}\right)_{4}\left(3 \times 10^{-5} \mathrm{M}\right)$ with coronene in $\mathrm{CH}_{3} \mathrm{CN}$ at $298 \mathrm{~K}$. The inset plot represents the variation of the intensity of the bands at 339, 323, 334 and $345 \mathrm{~nm}$ against the [coronene]/[3] $([\mathrm{G}] /[\mathrm{H}])$ ratio 
A second isosbestic point can also be observed at $368 \mathrm{~nm}$. The changes in the absorbances were found to give saturation upon addition of 8 equivalents of the guest. Based on the changes observed, the binding constants were determined using a global fitting analysis.[32] Again, we found that the best fit was obtained when we used a 1:2 H:G stoichiometric model, which allowed us to obtain the association constants for the formation of the $1: 1$ and $1: 2 \mathrm{H}: \mathrm{G}$ complexes. The values obtained were $\mathrm{K}_{11}=5.0(8) \times 10^{4} \mathrm{M}^{-1}$, and $\mathrm{K}_{12}=7.4(4) \times 10^{3} \mathrm{M}^{-1}$.

Given the large association constant found for $[3]\left(\mathrm{BF}_{4}\right)_{4}$ with coronene, we tested the metallosquare as coronene scavenger in $\mathrm{CH}_{3} \mathrm{CN}$. For this experiment we prepared a $1 \mathrm{mM}$ solution of coronene in $\mathrm{CH}_{3} \mathrm{CN}$. The irradiation of this solution with UV light $(365 \mathrm{~nm})$ produces a strong emission due to the fluorescence properties of coronene. Then 0.5 equivalents of $[3]\left(\mathrm{BF}_{4}\right)_{4}$ was added, and the resulting solution resulted non-emissive upon irradiation with UV light, a clear indication that coronene was encapsulated within the metallosquare (Figure 3).

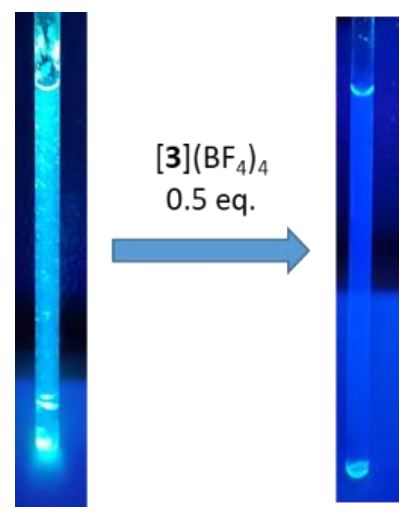

Figure 3. A sample of coronene $(1 \mathrm{mM})$ in $\mathrm{CH}_{3} \mathrm{CN}$ irradiated with $\mathrm{UV}$ light before (left) and after (right) adding 0.5 equivalents of $[3]\left(\mathrm{BF}_{4}\right)_{4}$. 
Once the ability of $[3]\left(\mathrm{BF}_{4}\right)_{4}$ to encapsulate several polycyclic aromatic hydrocarbons was proved, we decided to see if we could enforce the trapping of three guests. For the design of effective aromatic stacks, it is important to consider that A-A and D-A interactions are known to be more favorable than D-D stacks.[33, 34] Taking this into account, we thought that the incorporation of the electron-poor N,N'-dimethylnaphthalenetetracarboxy diimide (NTCDI) as heteroguest, should favor the formation of D-A-D-A-D quintuple stacks by intercalating between the electron-rich PAH guests and the pyrene panels of the cage. The experiments were carried out by subsequently adding two equivalents of PAH (pyrene, triphenylene or coronene) and two equivalents of NTCDI to a solution of $[3]\left(\mathrm{BF}_{4}\right)_{4}$ in $\mathrm{CD}_{3} \mathrm{CN}$ (Scheme 2). The formation of the quintuple stacking structures was strongly supported by NMR spectroscopy and mass spectrometry.

The High Resolution Mass Spectrometric (HRMS) studies of the mixtures, showed intense peaks at $\mathrm{m} / \mathrm{z} 988.5,964.0$ and 970.5 , for the mixtures of $[3]\left(\mathrm{BF}_{4}\right)_{4}$ with coronene, pyrene and triphenylene, respectively, which are assigned to $[3 \supset(\mathrm{PAH}+2 \mathrm{NTCDI})]^{4+}$. The formation of the same host:guest complex product could also be accomplished by inverting the order of addition of the guests (first NTCDI and then the PAH). As an illustrative example, Figure 4 shows the mass spectrum obtained for the mixture of $[3]\left(\mathrm{BF}_{4}\right)_{4}$ with NTCDI and coronene. 


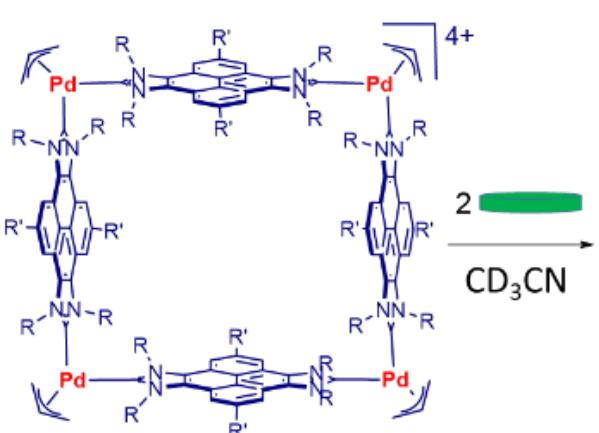

$[3]^{4+}$

$=\mathrm{PAH}=$ pyrene, triphenylene or coronene

$=$ NTCDI

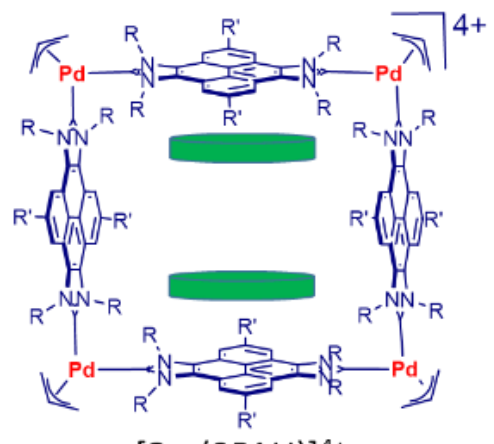

[3つ(2PAH) $]^{4+}$

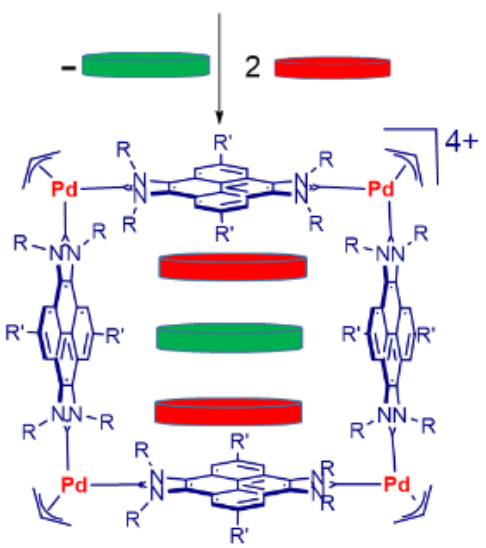

[3D(PAH+2NTCDI) $]^{4+}$

Scheme 2. Sequential encapsulation of PAH and NTCDI into the cavity of the metallosquare $[3]^{4+}$.

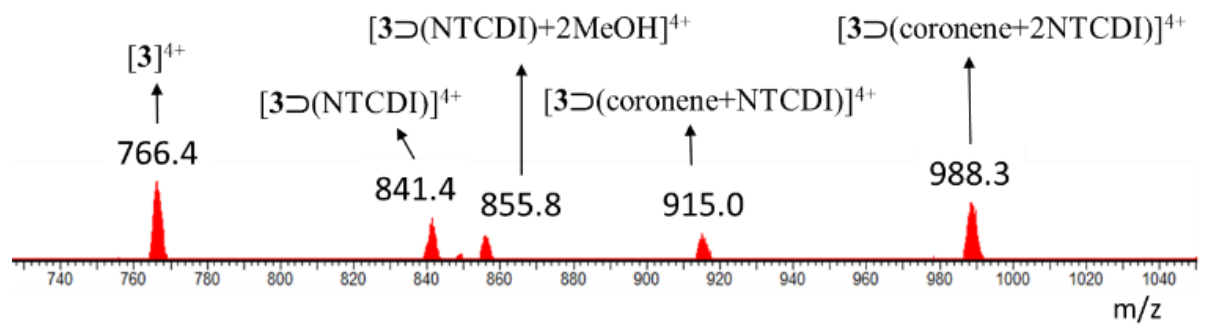

Figure 4. High Resolution Mass Spectrum (HRMS) of a mixture of $[3]\left(\mathrm{BF}_{4}\right)_{4}$ with coronene and NTCDI in $\mathrm{CH}_{3} \mathrm{CN}$ at $298 \mathrm{~K}$. 
The quintuple stacking is also supported by NMR spectroscopy. As an illustrative example, Figure 5 shows a series of comparative spectra for the encapsulation of coronene and NTCDI in $[3]\left(\mathrm{BF}_{4}\right)_{4}$. The encapsulation of the heteroguests inside the cavity of $[3]\left(\mathrm{BF}_{4}\right)_{4}$ breaks the simmetry of the host, as evidenced by the appeareance of three separate sets of signals assigned to the protons of the vertical (two sets) and horizontal (one set) pyrene panels of the cage. A similar splitting is observed for the resonances due to the allyl protons and to the protons of the methylene group bound to the nitrogens of the imidazolylidenes.

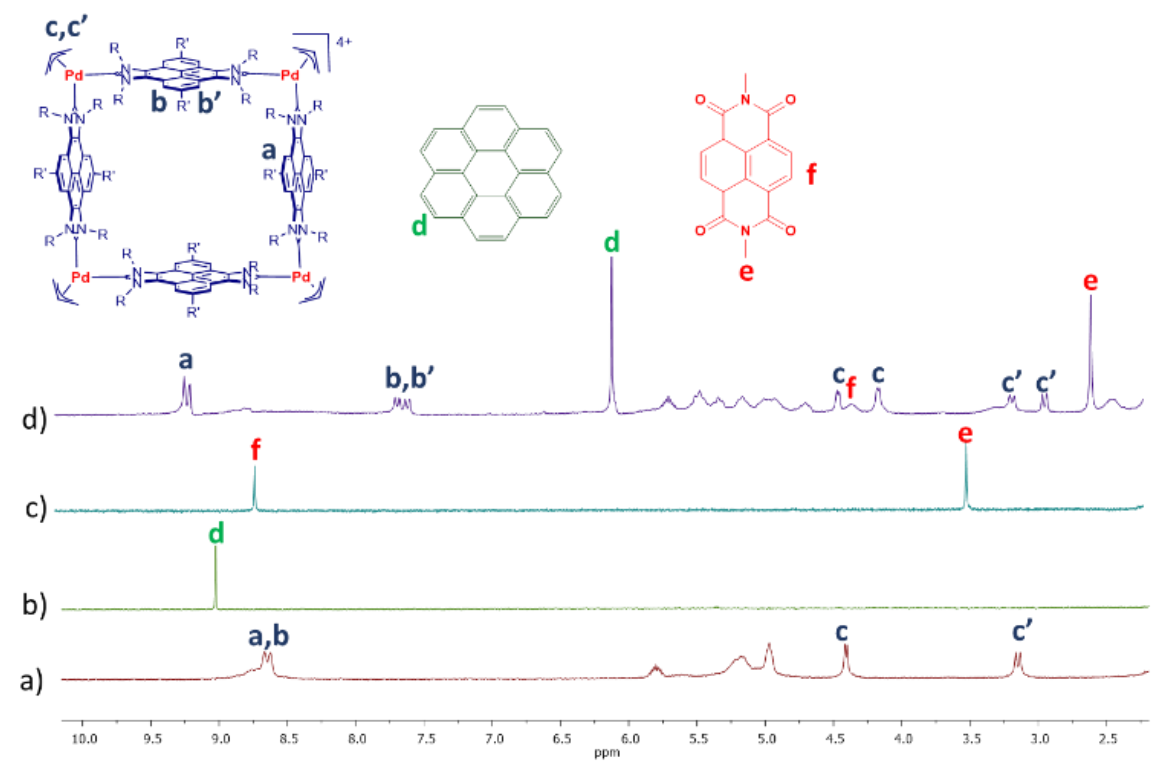

Figure 5. Selected region of the ${ }^{1} \mathrm{H}$ NMR spectra of a) $\left.[3]\left(\mathrm{BF}_{4}\right)_{4}, \mathrm{~b}\right)$ coronene, c) $\mathrm{NTCDI}$, and d) $[3 \supset(\text { coronene+2NTCDI })]^{4+}$. All spectra carried out in $\mathrm{CD}_{3} \mathrm{CN}$ at room teperature.

The fact that these changes can be observed by ${ }^{1} \mathrm{H}$ NMR spectroscopy at room temperature indicates that the site-exchange of guests in the host:guest complex is slow on the NMR timescale. The signals of both, 
coronene and NTCDI are strongly shifted upfield due to the encapsulation in the cavity of $3^{4+}$, and the integrals of the protons assigned to $\mathbf{3}^{4+}$, coronene and NTCDI are in perfect agreement with a $3^{4+}$ :coronene:NTCDI ratio of $1: 1: 2$.

The order of the D-A-D-A-D stacks is also confirmed by ${ }^{1} \mathrm{H}-{ }^{1} \mathrm{H}$ ROESY NMR, which shows coupling between the signals due to the methyl group of NTCDI, and the signals due to the neighboring coronene (see ESI). The resonances due to the methyl group of NTCDI, also show ROESY coupling with the signals due to the protons of the methyl group of the tert-butyl moieties bound to the pyrene panels of the metallosquare. These observations are a clear indication that each molecule of NTCDI is sandwiched in between one molecule of coronene and one of the pyrene moieties of the metallosquare. Finally, the Diffusion Ordered NMR spectrum (DOSY) of $[3 \supset(\text { coronene }+2 \mathrm{NTCDI})]^{4+}$ shows that all proton resonances display the same diffusion coefficient in $\mathrm{CD}_{3} \mathrm{CN}\left(\mathrm{D}=5.81 \times 10^{-10} \mathrm{~m}^{2} \mathrm{~s}^{-1}\right)$, indicating that all three molecules of guests are associated with the metallosquare forming a single assembly (see ESI). Similar conclusions can be derived from the analyses of the NMR studies carried out for $\quad[3 \supset(\text { pyrene+2NTCDI })]^{4+}, \quad$ and $\left[3 \supset(\text { triphenylene+2NTCDI) }]^{4+}\right.$ (see ESI for all details).

The formation of the quintuple-stacked supramolecular system was also studied by Uv-Vis- spectroscopy. The addition of two equivalents of NTCDI on a solution of [3](BF $)_{4}$ in $\mathrm{CH}_{3} \mathrm{CN}$ induced the appearance of a CT band at around $382 \mathrm{~nm}$. This band is red-shifted compared to the weaker band shown by 'empty' $[3]\left(\mathrm{BF}_{4}\right)_{4}(376 \mathrm{~nm})$, most likely due 
to the formation of D-A stacks between the pyrene panels of the cage (D) and the NTCDI guest (A). Subsequent addition of coronene (or triphenylene) moves the absorption band back to $376 \mathrm{~nm}$, due to the incorporation of the molecule of coronene (or triphenylene) to the system forming a D-A-D-A-D stack. In this quintuple stack the charge transfer probably goes mainly from the molecule of coronene (or triphenylene) to NTCDI, thus reducing the participation of the pyrene panels in the CT process, which should explain why the absorption band due to pyrene moves back to $376 \mathrm{~nm}$ (see Figures S39 and S40 in ESI).

In conclusion, we found that our organometallic-based metallosquare displays a perfect size for the effective encapsulation of three large $\pi$ conjugated heteroguests, enabling the formation of quintuple D-A-DA-D stacks. Unlike any other metallosupramolecular systems previously used for the encapsulation of multiple heteroguests, our system is the first one to show a square structure, while all other known examples are based on 'closed' trigonal prismatic architectures. Given the large number of Janus di-NHC ligands connected by large $\pi$ conjugated systems that we have prepared in our lab during the last few years, we believe that we are in a priviledged position for desinging new metallosupramolecular templates for tailoring discrete $\pi$-stacks of varying heights and compositions. Enabling effective methods for achieving tailor-made aromatic stacks is necessary to enrich our ability to manipulate material properties at the supramolecular level. 
8. Article 5

\section{Acknowledgements}

We gratefully acknowledge financial support from the Ministerio de Ciencia y Universidades (PGC2018-093382-B-I00) and the Universitat Jaume I (UJI-B2017-07). We are grateful to the Serveis Centrals d'Instrumentació Científica (SCIC-UJI) for providing with spectroscopic facilities. 


\section{References}

1. Yoshizawa, M., J.K. Klosterman, and M. Fujita, Functional Molecular Flasks: New Properties and Reactions within Discrete, Self-Assembled Hosts. Angewandte Chemie-International Edition, 2009. 48(19): p. 3418-3438.

2. Leenders, S.H.A.M., et al., Transition metal catalysis in confined spaces. Chemical Society Reviews, 2015. 44: p. 433-448.

3. Meeuwissen, J. and J.N.H. Reek, Supramolecular catalysis beyond enzyme mimics. Nature Chemistry, 2010. 2(8): p. 615-621.

4. Koblenz, T.S., J. Wassenaar, and J.N.H. Reek, Reactivity within a confined self-assembled nanospace. Chemical Society Reviews, 2008. 37(2): p. 247-262.

5. Wiester, M.J., P.A. Ulmann, and C.A. Mirkin, Enzyme Mimics Based Upon Supramolecular Coordination Chemistry. Angewandte Chemie-International Edition, 2011. 50(1): p. 114-137.

6. Horiuchi, S., T. Murase, and M. Fujita, Noncovalent Trapping and Stabilization of Dinuclear Ruthenium Complexes within a Coordination Cage. Journal of the American Chemical Society, 2011. 133(32): p. 12445-12447.

7. Kawano, M., et al., Direct crystallographic observation of a coordinatively unsaturated transition-metal complex in situ generated within a self-assembled cage. Journal of the American Chemical Society, 2006. 128(20): p. 6558-6559.

8. Fujii, S., et al., Rectifying Electron-Transport Properties through Stacks of Aromatic Molecules Inserted into a Self-Assembled Cage. Journal of the American Chemical Society, 2015. 137(18): p. 59395947.

9. Klosterman, J.K., Y. Yamauchi, and M. Fujita, Engineering discrete stacks of aromatic molecules. Chemical Society Reviews, 2009. 38(6): p. 1714-1725.

10. Maurizot, V., et al., Control of molecular interactions by the hollow of coordination cages. Dalton Transactions, 2006(23): p. 2750-2756.

11. Yoshizawa, M., et al., Discrete stacking of large aromatic molecules 
within organic-pillared coordination cages. Angewandte ChemieInternational Edition, 2005. 44(12): p. 1810-1813.

12. Chen, L.J. and H.B. Yang, Construction of Stimuli-Responsive Functional Materials via Hierarchical Self-Assembly Involving Coordination Interactions. Accounts of Chemical Research, 2018. 51(11): p. 2699-2710.

13. Borsley, S., et al., Nanopore Detection of Single-Molecule Binding within a Metallosupramolecular Cage. Chemistry-a European Journal, 2018. 24(18): p. 4542-4546.

14. Takezawa, H., et al., Recognition of Polyfluorinated Compounds Through Self-Aggregation in a Cavity. Journal of the American Chemical Society, 2014. 136(5): p. 1786-1788.

15. Therrien, B., Drug Delivery by Water-Soluble Organometallic Cages. Chemistry of Nanocontainers, 2012. 319: p. 35-55.

16. Zava, O., et al., Evidence for Drug Release from a Metalla-Cage Delivery Vector Following Cellular Internalisation. Chemistry-a European Journal, 2010. 16(5): p. 1428-1431.

17. Lewis, J.E.M., et al., Stimuli-responsive Pd2L4 metallosupramolecular cages: towards targeted cisplatin drug delivery. Chemical Science, 2012. 3(3): p. 778-784.

18. Casini, A., B. Woods, and M. Wenzel, The Promise of SelfAssembled 3D Supramolecular Coordination Complexes for Biomedical Applications. Inorganic Chemistry, 2017. 56(24): p. 14715-14729.

19. Rizzuto, F.J., L.K.S. von Krbek, and J.R. Nitschke, Strategies for binding multiple guests in metal-organic cages. Nature Reviews Chemistry, 2019. 3(4): p. 204-222.

20. Iwane, M., et al., Controlling stacking order and charge transport in -stacks of aromatic molecules based on surface assembly. Chemical Communications, 2018. 54(88): p. 12419-12532.

21. Yamauchi, Y., et al., Engineering Double to Quintuple Stacks of a Polarized Aromatic in Confined Cavities. Journal of the American Chemical Society, 2010. 132(3): p. 960-966.

22. Murase, T., K. Otsuka, and M. Fujita, Pairwise Selective Formation 
of Aromatic Stacks in a Coordination Cage. Journal of the American Chemical Society, 2010. 132(23): p. 7864-7865.

23. Singh, N., et al., Coordination-driven self-assembly of an iridiumcornered prismatic cage and encapsulation of three heteroguests in its large cavity. Chemical Communications, 2015. 51(21): p. 44924495.

24. Sinha, A., et al., Single-Step Synthesis of Organometallic Molecular Squares from NR,NR',NR',NR', -Substituted Benzobiscarbenes. Chemistry-a European Journal, 2017. 23(25): p. 5939-5942.

25. Conrady, F.M., et al., Stepwise Formation of a Molecular Square with Bridging NH,O-Substituted Dicarbene Building Blocks. Journal of the American Chemical Society, 2011. 133(30): p. 11496-11499.

26. Martinez-Agramunt, V., S. Ruiz-Botella, and E. Peris, NickelCornered Molecular Rectangles as Polycyclic Aromatic Hydrocarbon Receptors. Chemistry-a European Journal, 2017. 23(27): p. 6675-6681.

27. Martinez-Agramunt, V. and E. Peris, Photocatalytic Properties of a Palladium Metallosquare with Encapsulated Fullerenes via Singlet Oxygen Generation. Inorganic Chemistry, 2019. 58(17): p. 1183611842.

28. Martinez-Agramunt, V., et al., A Size-Flexible Organometallic Box for the Encapsulation of Fullerenes. Angewandte ChemieInternational Edition, 2019. 58(17): p. 5682-5686.

29. Dale, E.J., et al., ExCage. Journal of the American Chemical Society, 2014. 136(30): p. 10669-10682.

30. Barnes, J.C., et al., ExBox: A Polycyclic Aromatic Hydrocarbon Scavenger. Journal of the American Chemical Society, 2013. 135(1): p. 183-192.

31. Ibañez, S. and E. Peris, A Rigid Trigonal-Prismatic Hexagold Metallocage That Behaves as a Coronene Trap. Angewandte Chemie-International Edition, 2019. 58(20): p. 6693-6697.

32. Lowe, A.J., F.M. Pfeffer, and P. Thordarson, Determining binding constants from H-1 NMR titration data using global and local methods: a case study using $n$ polynorbornane-based anion hosts. 
Supramolecular Chemistry, 2012. 24(8): p. 585-594.

33. Cozzi, F., et al., DOMINANCE OF POLAR/PI OVER CHARGETRANSFER EFFECTS IN STACKED PHENYL INTERACTIONS. Journal of the American Chemical Society, 1993. 115(12): p. 53305331.

34. Cozzi, F., et al., POLAR/PI INTERACTIONS BETWEEN STACKED ARYLS IN 1,8-DIARYLNAPHTHALENES. Journal of the American Chemical Society, 1992. 114(14): p. 5729-5733.

35. Martínez-Agramunt, V., et al., A size-flexible organometallic box for the encapsulation of fullerenes. Angewandte Chemie, International Edition, 2019. 58(17): p. 5682-5686.

36. Thordarson, P., Determining association constants from titration experiments in supramolecular chemistry. Chemical Society Reviews, 2011.40(3): p. 1305-1323. 
9. Conclusions

\section{CONCLUSIONS}

- A novel family of four pyrene-based Supramolecular Organometallic Complexes (SOCs) with different geometries has been obtained.

- A selective PAH-receptor was obtained, able to distinguish between the different PAH according to their shape, size, and number of $\pi$ electrons.

- We develop an efficient strategy for the extraction of the toxic and carcinogenic PAH from organic solvents in which our system behaves as PAH-scavenger.

- Two selective fullerene receptors were obtained, able to adapt their size to the shape of the fullerene. Due to the higher affinity towards one specific fullerene, this constitutes a potential new efficient method of purification of fullerenes.

- We report the first host-guest system used as photosensitizer in the singlet oxygen generation. The fullerene-containing SOC, was able to oxidase a great variety of alkenes towards the generation of singlet oxygen from atmospheric air under visible light.

- Multiple-guest encapsulation was achieved inside our SOCs, obtaining a host-guest system with quintuple D-A-D-A-D stacks. 
9. Conclusiones

\section{CONCLUSIONES}

- Una nueva familia de cuatro Complejos Organometálicos Supramoleculares (SOCs) basados en pireno ha sido obtenida.

- Un nuevo receptor de PAH selective ha sido obtenido, capaz de discerner entre los diferentes PAH en función de su forma, tamaño, y número de electrones- $\pi$.

- Hemos desarrollado una estrategia eficiente para la extracción de $\mathrm{PAH}$, que son compuestos tóxicos y carcinogénicos, en disolventes orgánicos en los que nuestro sistema se comporta como extractor de PAH.

- Dos receptors de fulereno han sido obtenidos, capaces de adaptar su tamaño a la forma de fulereno. Debido a la mayor afinidad respect a un fulereno específico, constituye potencialmente un Nuevo método de purificación de fulerenos.

- Describimos el primer sistema host-guest utilizado como fotosensibilidazor en la generación de oxígeno singlete. Este SOC con fulereno atrapado, fue capaz de oxidar una gran variedad de alquenos utilizando el oxígeno singlete generado a partir de aire a presión atmosférica y luz visible.

- Se encapsularon multiples moléculas en el interior de nuestra caja, obteniendo un sistema host-guest con apilamiento tipo D-A-D-A-D. 
